$$
\begin{aligned}
& \text { MEIO AMBIENTE } \\
& \text { SUSTENTABILIDADE } \\
& \text { \& } \\
& \text { TEC NOLOG।A }
\end{aligned}
$$

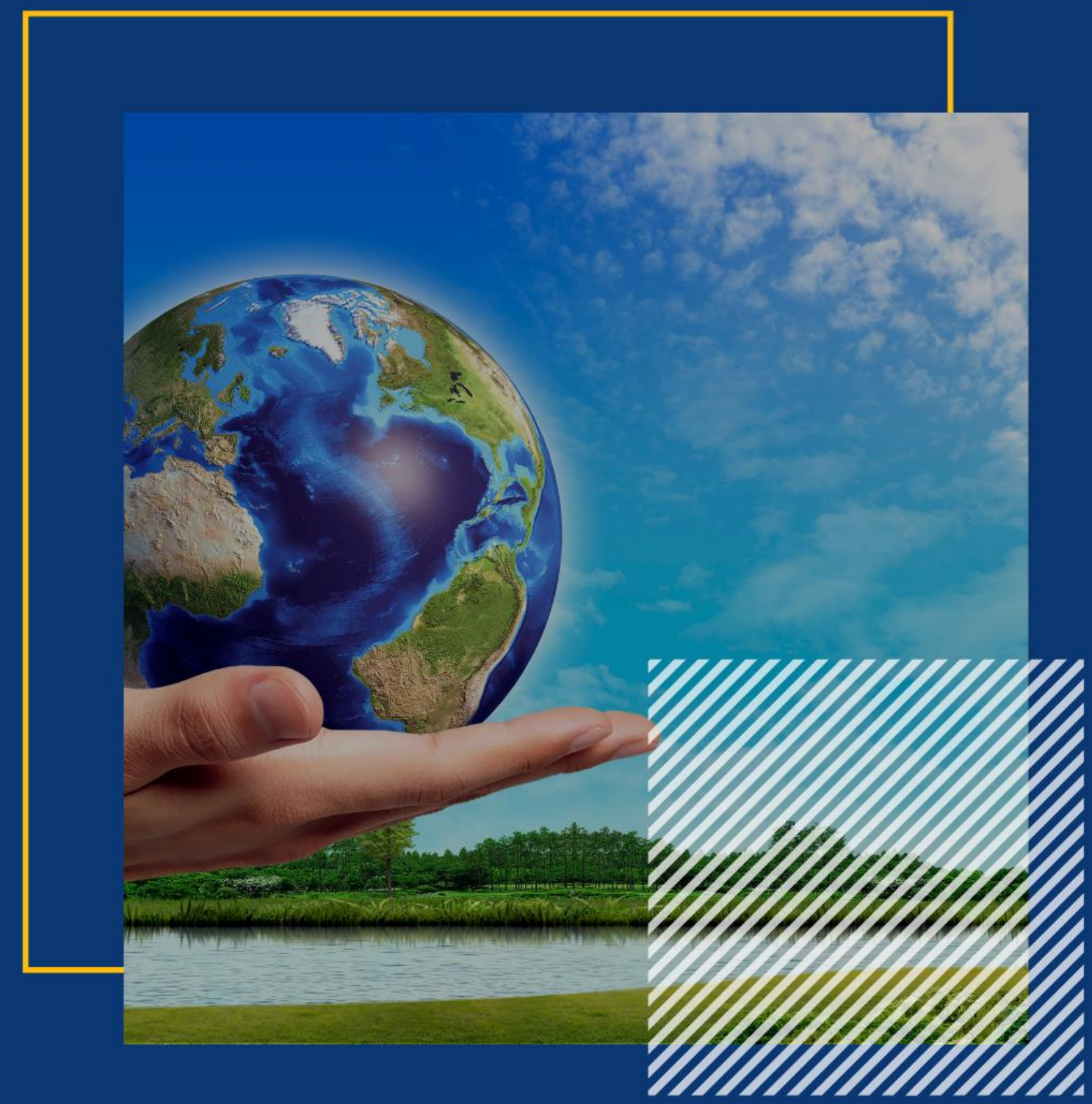

(Organizador)

José Henrique Porto Silveira

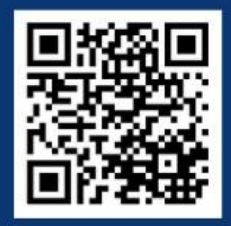


Organizador

José Henrique Porto Silveira

\title{
Meio Ambiente, Sustentabilidade e Tecnologia Volume 7
}

\author{
1a Edição
}

Belo Horizonte

Poisson

2021 
Editor Chefe: Dr. Darly Fernando Andrade

\section{Conselho Editorial}

Dr. Antônio Artur de Souza - Universidade Federal de Minas Gerais

Ms. Davilson Eduardo Andrade

Dra. Elizângela de Jesus Oliveira - Universidade Federal do Amazonas

Msc. Fabiane dos Santos

Dr. José Eduardo Ferreira Lopes - Universidade Federal de Uberlândia

Dr. Otaviano Francisco Neves - Pontifícia Universidade Católica de Minas Gerais

Dr. Luiz Cláudio de Lima - Universidade FUMEC

Dr. Nelson Ferreira Filho - Faculdades Kennedy

Ms. Valdiney Alves de Oliveira - Universidade Federal de Uberlândia

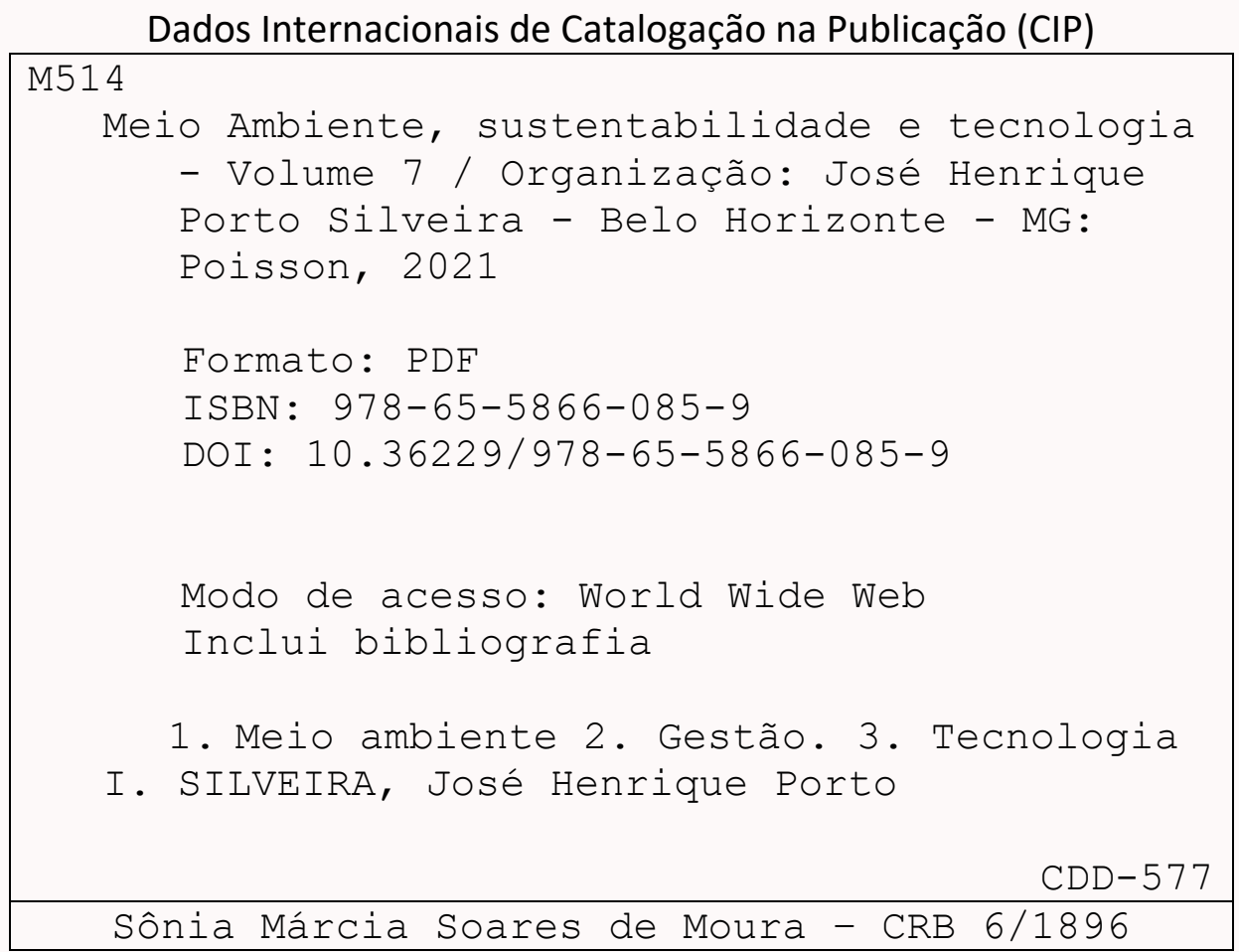

O conteúdo deste livro está licenciado sob a Licença de Atribuição Creative Commons 4.0.

Com ela é permitido compartilhar o livro, devendo ser dado o devido crédito, não podendo ser utilizado para fins comerciais e nem ser alterada.

O conteúdo dos artigos e seus dados em sua forma, correção e confiabilidade são de responsabilidade exclusiva dos seus respectivos autores.

$\underline{\text { www.poisson.com.br }}$

contato@poisson.com.br 


\section{Prefácio}

A trajetória dos seres humanos vem sendo escrita com ênfase sempre na nossa infinita capacidade de subjugar a natureza, extrair dela o que nos interessa e descartar o que não nos serve na forma de resíduos. Tais resíduos no ar, na água ou no solo representam o que deve ser evitado, mitigado ou controlado. É poluição ou degradação. Em grande parte essa trajetória desastrada é decorrente da evolução das ciências e suas tecnologias.

Mas quando se começa perceber o desastre, mesmo que lenta e gradativamente a ciências e suas tecnologias podem se constituir em reversão da catástrofe prenunciada. Novos tempos, tempos de pensar de forma sistêmica e ecológica.

Nessa perspectiva, meio ambiente e sustentabilidade são expressões fundamentais. Conceitos distintos, mas indissociáveis para podermos pensar para agir e agir para construir o futuro da humanidade. É assim que as ciências atuam, buscando respostas com a ampliação dos conhecimentos e encontrando soluções com novas tecnologias. Nesta busca incessante para criar e construir soluções para os problemas ambientais e de encontrar caminhos para manifestação dos preceitos da sustentabilidade, tecnologias são ensaiadas e sugeridas como viáveis e mesmo projetadas para execução.

E este é o verdadeiro papel das ciências nas academias e nos centros de pesquisa, envolvendo as muitas disciplinas que se integram na construção do conhecimento socioambiental: engenharia, arquitetura, sociologia, psicologia, geografia, antropologia, biologia, pedagogia e tantas outras. Quase sempre são processos que envolvem a multi, a inter e a transdisciplinaridade.

Nessa coletânea, a intenção principal é mostrar possibilidades, algumas mais outras menos detalhadas, mas todas dotadas de intencionalidades em relação à busca de um futuro melhor.

Como ambientalista e profissional com muitos anos de atuação nas áreas de avaliação de impactos e educação ambiental vejo como muito promissor as ideias e soluções técnicas que estão sendo gestadas no meio acadêmico nas áreas de meio ambiente e sustentabilidade.

Reitero que as temáticas como meio ambiente e sustentabilidade devem estar em constante interação na construção do futuro, já que inevitavelmente a nossa permanência como espécie depende da permanência de outras espécies da flora e da fauna e da boa qualidade dos elementos ar, água e solo. Nunca é tarde na busca de reverter a nossa trajetória, usando bom senso e o conhecimento proporcionado pelas ciências e pelas culturas milenares sobre o meio ambiente. 


\section{Sumário}

Capítulo 1: Guattari e Deleuze: Três textos filosóficos para fazer pensar a Educação Ambiental. 08

Antônio Sérgio da Costa, João Luis Rodrigues, Rafael Fernandes Barros de Souza

DOI: 10.36229/978-65-5866-085-9.CAP.01

Capítulo 2: Desmitificar para conservar: 0 conhecimento etnoherpetológico de alunos do Ensino Fundamental II

Monique Dias Benedetti, Luiz Fernando Ferreira, Ana Caroline Vitor Avelar, Fabíola Mangabeira Ceolato da Silva, Daniela Ferreira Cardoso

DOI: $10.36229 / 978-65-5866-085-9 . C A P .02$

Capítulo 3: Estado de conservação e potencial da regeneração natural para restauração de áreas antropizadas no noroeste do Rio Grande do Sul. 17

Adriana Maria Griebeler, Felipe Turchetto

DOI: 10.36229/978-65-5866-085-9.CAP.03

Capítulo 4: Compostagem doméstica: Uma prática adequada de transformação, diminuição e disposição alternativa dos resíduos orgânicos gerados em ambientes domiciliares.

Francisco Edirlan de Sousa Freitas, Everlene de Sousa Freitas, Laís Regina Gomes de Oliveira Freitas DOI: $10.36229 / 978-65-5866-085-9 . C A P .04$

Capítulo 5: Efluentes domésticos e seus impactos no meio ambiente no bairro do Alegre em Bragança - PA 33

Odilon Augusto Rêgo de Lima, Luciana Leal Pimentel Oliveira

DOI: $10.36229 / 978-65-5866-085-9 . C A P .05$

Capítulo 6: Sistema de tratamento de esgoto total com reator UASB em comunidades rurais no Semiárido Baiano. 41

Clérison dos Santos Belém, André Azevedo Rocha, Miriam Cleide Cavalcante Amorim, Carlos Laécio Evangelista Franca

DOI: $10.36229 / 978-65-5866-085-9 . C A P .06$

Capítulo 7: Comportamento de aves em áreas urbanas: Um estudo de caso. 46

Rafael Natal Xavier Souza, Rita Tassiana da Costa, Regiane Aparecida Negri

DOI: 10.36229/978-65-5866-085-9.CAP.07 


\section{Sumário}

Capítulo 8: A análise da arborização urbana como perspectiva de desenvolvimento da sustentabilidade na Subprefeitura do Butantã, no município de São Paulo, SP. 53

Amanda Lombardo Fruehauf, Paulo Renato Mesquita Pellegrino, Magda Adelaide Lombardo

DOI: 10.36229/978-65-5866-085-9.CAP.08

Capítulo 9: Plástico verde obtido do bagaço da cana-de-açúcar: Aspectos econômicos e sociais. 60

Claudia Rebechi Yokota, Cristina Martinelli, Simone Aparecida Rigobeli Vanalli, Otávio Akira Sakai, Stella Alonso Rocha

DOI: 10.36229/978-65-5866-085-9.CAP.09

Capítulo 10: Empreendedorismo social e sustentabilidade: Análise acerca do trabalho das mulheres membras da Cooperativa de Mulheres Artesãs do Poti Velho (COOPERART- Poti) em Teresina-Piauí 68

João Lucas Queiroz Brandão, Ione Cristina Dantas Ribeiro

DOI: 10.36229/978-65-5866-085-9.CAP.10

Capítulo 11: Responsabilidade empresarial sustentável: Impacto social promovendo sucesso empresarial

Ari Melo Mariano, Caroline Helena Ramos de Queiroz, Fabrício Curvelo Camara Sales, Paulo Roberto Cuoco de Melo, Camila Rodrigues Lima

DOI: 10.36229/978-65-5866-085-9.CAP.11

Capítulo 12: Aspectos socioeconômicos da agricultura orgânica no estado de Roraima: Um estudo com a Associação Hortivida 91

Dayana Machado Rocha, Emerson Clayton Arantes

DOI: 10.36229/978-65-5866-085-9.CAP.12

Capítulo 13: Certificação e produção orgânica no Brasil 100

Guilherme Patricio de Araujo, Marta Cristina Marjotta-Maistro, Amanda Rezzieri Marchezini

DOI: 10.36229/978-65-5866-085-9.CAP.13

Capítulo 14: Sustentabilidade socioambiental e impactos na geração elétrica nos pequenos potenciais hídricos do rio Muatala, Nampula - Moçambique

Alcido Alberto João, António Gonçalves Fortes, Momade Jaime Chau, Claudino Pita Richad, Paulo Baptista Alface, Ernesto Taperero Fernando

DOI: 10.36229/978-65-5866-085-9.CAP.14 


\section{Sumário}

Capítulo 15: Análise do perfil da pegada hídrica cinza da rizicultura no perímetro irrigado Betume, Neópolis - SE

Camilo Rafael Pereira Brandão, Inajá Francisco de Sousa

DOI: $10.36229 / 978-65-5866-085-9 . C A P .15$

Capítulo 16: Estudo de um processo de baixo custo para a separação da emulsão óleoágua de fluido de corte emulsionável.

Joyce Aparecida Pifano de Oliveira, Paulo Cézar Gonçalves, Kátia Valéria Marques Cardoso Prates, Janksyn Bertozzi, Janaina Fracaro de Souza Gonçalves

DOI: $10.36229 / 978-65-5866-085-9 . C A P .16$

Capítulo 17: Fungos filamentosos em solo de caatinga salinizada no Vale do Submédio São Francisco, Brasil

Cledson Sandro Barros de Sá, Ricardo Kenji Shiosaki, Maryluce Albuquerque da Silva Campos, Leilyane Conceição de Souza Coelho, Antônio Marcos dos Santos

DOI: $10.36229 / 978-65-5866-085-9 . C A P .17$

Capítulo 18: Síntese de carvão ativado fisicamente com vapor de água visando tratamento de efluentes industriais para fins de reúso

Ricardo Francisco Alves, José Luiz Francisco Alves, Jean Constantino Gomes da Silva, Emmely Oliveira da Trindade, Guilherme Davi Mumbach, Rênnio Felix de Sena

DOI: $10.36229 / 978-65-5866-085-9 . C A P .18$

Capítulo 19: Development of tree species from Brazilian savanna consortiated with green manures in a revegetated area 146

Eva de Melo Ferreira, Michel de Paula Andraus, Aline Assis Cardoso, Wilson Mozena Leandro

DOI: 10.36229/978-65-5866-085-9.CAP.19

Capítulo 20: Google Earth Engine aplicado análise multitemporal de área afetadas pela instalação da usina de Belo Monte - Pa. 156

Juliana Tamires Ferreira Kizahy Nagem, Maria Luiza de Castro Garcia, Karen Patrícia Macedo Cesário, Lucas Daniel Noronha Ferreira, Mozart dos Santos Silva, Patrick Rafael Silva Correa

DOI: $10.36229 / 978-65-5866-085-9 . C A P .20$

Autores: 161 


\section{Capítulo 1}

Guattari e Deleuze: Três textos filosóficos para fazer pensar a Educação Ambiental

\section{Antônio Sérgio da Costa}

João Luis Rodrigues

Rafael Fernandes Barros de Souza

Resumo: A preocupação com a natureza percorre a trajetória do pensamento da humanidade. No século $\mathrm{XX}$, por sua vez, as questões ambientais ganham conexão filosófica, com noções que refletem a essência humana e redimensionam o meio ambiente. Nesse contexto é que se destacam os pensadores franceses Félix Guattari (1930-1992) e Gilles Deleuze (1925-1995). Será feito aqui uma revisão de literatura a partir de três obras dos autores: Instintos e Instituições (1955), de Deleuze; Três Ecologias (1989) de Guattari, e 0 que é Filosofia? (1991) escrito por ambos. 0 objetivo é demonstrar a relevância do pensamento de tais filósofos nas indagações ambientais do nosso tempo baseado em textos que ampliam discussões sobre "subjetividade humana", "inteligência coletiva", "dimensão conceitual" e "práxis social". Com base no referencial teórico é possível considerar que são várias e relevantes as "ressonâncias" refletidas por Guattari e Deleuze sobre o meio ambiente, tornando-os autores fundamentais para se pensar a Educação Ambiental.

Palavras-chave: Filosofia; Meio Ambiente; Subjetividade Humana; Práxis Ambiental.

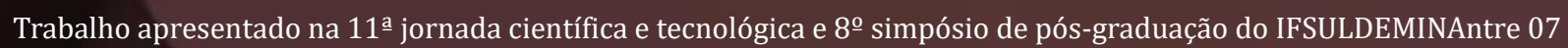
e 08 de novembro de 2019, no IFSULDEMINAS - Campus Inconfidentes. 


\section{INTRODUÇÃO}

A preocupação com o meio ambiente percorre a trajetória do pensamento da humanidade. Aristóteles, na Antiguidade, concebia o ser humano como parte da natureza e ambos na busca do equilíbrio. Santo Agostinho, na Idade Média, compreendia a natureza como uma livre criação de Deus e, portanto, algo sempre bom. Para Rousseau, na Idade Moderna, o ser humano está junto e com a natureza e mantém para com ela um sentimento subjetivo, que lhe permite preservá-la. Karl Marx, no século XIX, não reduzia a natureza ao universo biológico somente, mas pensava o ser humano como parte que se relaciona dialeticamente com o meio ambiente.

É no decorrer do século anterior, contudo, que as questões ambientais ganham crescente destaque nas discussões da sociedade contemporânea. É possível, então, compreender uma conexão filosófica ainda mais efetiva com a natureza, ou seja, os problemas ambientais ganham caráter essencialmente humano, que envolvem desde conhecimento científico a valores do homem. Nesse contexto que se destacam os pensadores franceses Felix Guattari (1930-1992) e Gilles Deleuze (1925-1995). Ambos têm em suas obras essa mesma preocupação em discutir as interconexões entre as esferas sociais e ambientais, quebrando, assim, a visão dualística do humano (cultural) e não-humano (natural). Defendem os filósofos que a ecologia é o estudo de fenômenos complexos, incluindo a subjetividade humana, o meio ambiente e as relações sociais, que estão intimamente interconectadas.

Será feito aqui uma revisão de literatura a partir de três obras dos autores: Instinto e Instituições (1955), de Deleuze; Três Ecologias de Guatarri (1989), e O que é Filosofia? (1991) escrito por ambos. O objetivo é demonstrar a relevância do pensamento de tais filósofos nas discussões ambientais em nosso tempo e mesmo no suporte reflexivo para a Educação Ambiental, pois, seus textos revelam termos como "inteligência coletiva". "subjetividade" e "dimensão conceitual" que muito podem contribuir para uma Educação Ambiental voltada para a práxis individual e social a partir, como argumenta a dupla, de experiências e vivências restauradoras dos encontros de cada um consigo, com o outro e com o todo.

\section{GUATTARI E DELEUZE}

Pierre Félix Guattari foi um psicanalista e filósofo nascido em 1930, em Villeneuve-les-Sablons, uma vila próxima de Paris, morreu em 1992 em Cour-Cheverny também na França. Obteve formação plural Farmácia, Música, Filosofia, Psicanálise - contudo, não concluiu nenhum curso de graduação. Trabalhou durante 40 anos, desde a sua fundação em 1953, numa clínica psiquiátrica, a Clínica La Borde. A produção intelectual desse filósofo é associada à sua militância política marxista, que concebe o pensamento como uma ferramenta de luta social. Entre suas obras principais destacam-se Psicanálise e Transversalidade (1972), A Revolução Molecular (1977), As Três Ecologias (1989) e Caosmose (1992). Pertence a Guattari, entre outras, a noção de transversalidade.

Gilles Deleuze, por sua vez, foi um filósofo francês nascido em 1925 e falecido em 1995 na cidade de Paris. Concluiu o curso de Filosofia na Universidade de Paris (Sorbonne) em 1948 e lecionou durante toda a sua vida como professor, primeiro em liceus e depois em várias universidades parisienses. A maioria da sua obra teve como foco a "História do Pensamento Filosófico" buscando apresentar uma nova visão sobre as ideias dos filósofos analisados, ou seja, novas rotas para a filosofia. Influenciado, principalmente, por Nietzsche, Bérgson e Spinoza construiu suas reflexões com base no cotidiano utilizando de forma magistral as mídias contemporâneas, em especial, o cinema. Entre suas principais obras destacam-se Diferença e Repetição (1968), Lógica e Sentido (1969) e Crítica e Clínica (1993).

Guattari e Deleuze se conheceram em 1969, deste encontro nasce uma grande amizade, surgindo entre eles uma extensa colaboração literária em parceria. Juntos escreveram vários livros tratando dos mais variados e amplos aspectos da realidade, abordando temáticas sobre meio ambiente, sociedade, cultura, subjetividade humana e tecnologia. Produziram obras como 0 anti-Édipo: Capitalismo e Esquizofrenia (1972), Mil Platôs (1980) e 0 que é Filosofia? (1991).

\section{INSTINTOS E INSTITUIÇÕES}

Instintos e Instituições é um artigo escrito em 1955 por Gilles Deleuze, de quatro páginas, que posiciona o ser humano diante da natureza revelando que toda experiência individual supõe a preexistência de um meio no qual é conduzida a experiência, seja o meio ambiente seja o meio institucional. 0 instinto e a instituição, assim, são meios para a realização e a sobrevivência humana. 
Ao tratar das "Instituições", Deleuze nos alerta para a "tirania" onde há muitas leis e poucas instituições, ao contrário, a democracia é um regime onde há muitas instituições e poucas leis. A opressão se mostra quando as leis incidem diretamente sobre os homens. Apesar de muitas leis, a degradação do ambiente tem sido predominante, tal fenômeno ocorre, entre outros motivos, porque nossas instituições (família, igreja, escola etc) não cumprem seu papel de conscientização e ação ambiental. Uma efetiva educação ambiental passa não pela "tirania" das leis ambientais, mas, antes de tudo, pela democracia das instituições.

Quanto aos "Instintos", o autor, ressalta o seu caráter "não individualista”, que satisfaz não só o indivíduo, mas toda a espécie, tal modelo é fundamental para se pensar as questões ambientais. É, portanto, o valor da coletividade no meio natural para moldar o meio institucional. Deleuze, assim, destaca a necessidade de uma "dimensão coletiva da inteligência". Diz o filósofo: "É preciso decerto reencontrar a ideia de que a inteligência é coisa social mais que individual" (DELEUZE, 1955, p.136).

\section{AS TRÊS ECOLOGIAS}

As Três Ecologias (1989) é uma das principais obras de Felix Guattari escrita em 1989, que realiza uma análise crítica no que tange a relação do ser humano com o meio ambiente, a partir de uma visão transversal que perpassa as dimensões social, mental e ambiental. Apesar de conter pouco mais de 50 páginas trata com profundidade questões ambientais numa abordagem que busca, por um lado, alertar para ações humanas sem projeção consciente que vem provocando diversos desequilíbrios no meio ambiente, por outro lado, enfatizar a formação de um novo ser humano voltado para a "ecosofia". As formações políticas e as instâncias executivas, segundo o autor, se mostram sem capacidade para apreender as questões ecológicas contentando em abordar ameaças ambientais unicamente numa perspectiva tecnocrática. “(...) ao passo que só uma articulação ético-política - a que chamo ecosofia entre os três registros ecológicos (o do meio ambiente, o das relações sociais e o da subjetividade humana) é que poderia esclarecer convenientemente tais questões" (GUATTARI, 1990, p.08).

Nessa perspectiva, o filósofo irá desenvolver suas "três ecologias", sendo que a ecologia social deverá trabalhar na "reconstrução das relações humanas em todos os níveis" - uma reinvenção dos modos de ser do indivíduo no meio social; já a ecologia mental (da subjetividade humana) terá o papel de possibilitar a renovação da relação sujeito com o corpo em suas instâncias psíquicas individuais e coletivas. Para o autor, a subjetividade deve ser aprendida, pensada e repensada para reformar a concepção do ser humano sobre si mesmo, perante a sociedade e perante o meio ambiente.

Guattari propõe, desse modo, uma articulação entre as três ecologias como forma não somente de compreender as relações do ser humano com a sociedade, com a subjetividade humana e com o meio ambiente, mas, principalmente, na recomposição das práxis humanas nos mais variados domínios. A busca por tal "práxis" pressupõe a subjetividade como meta a ser realcançada, a partir de um olhar transversal do indivíduo: "(...) é exatamente na articulação: da subjetividade em estado nascente, do socius em estado mutante, do meio ambiente no ponto em que pode ser reinventado, que estará em jogo a saída das crises maiores de nossa época" (GUATTARI, 1990, p.55).

\section{0 QUE É FILOSOFIA?}

0 que é Filosofia? é um livro escrito por Deleuze e Guattari em 1991, no final da carreira de ambos, que busca discutir , em aproximadamente 280 páginas, divididos em duas partes, vários temas relacionados à filosofia, como a função do filósofo, que segundo os autores é criar conceitos e não "descobrir" essências e nem contemplar o universo. Nas últimas décadas vários conceitos foram criados sobre questões ambientais (sustentabilidade, bioética, agroecologia etc ), o importante, contudo, é compreender o que nos ensinam esses filósofos: "Não há conceito simples. Todo conceito tem componentes, e se define por eles. Tem, portanto, uma cifra. É uma multiplicidade" (DELEUZE; GUATTARI, 1992, p.10). Dessa maneira, criar ou construir um conceito requer um processo de articulação de componentes relacionados a outros conceitos e às diversas áreas do saber. Sendo assim, os autores reforçam a ideia de que a Educação Ambiente deve ser essencialmente interdisciplinar.

No último exemplo (XIII) do capítulo derradeiro, Deleuze e Guattari ainda propõem uma visão holística do meio ambiente, ou seja, que busca um entendimento integral, a partir da criação conceitual de um "sistema nervoso da Terra", explicitando que "nem todo organismo é cerebrado, e nem toda vida é orgânica, mas há 
em toda a parte forças que constituem microcérebros, ou uma vida inorgânica das coisas" (DELEUZE; GUATTARI, 1992, pg. 273).

Desse modo, o importante na tarefa de "construir conceitos" é reconhecer a complexidade do problema (porque todo conceito está relacionado ao problema que o constrói). Um conceito ambiental, portanto, procura responder às questões evidentes, ou mesmo subjetivas, na sociedade contemporânea.

\section{CONSIDERAÇÕES FINAIS}

A primeira consideração que se pode chegar lendo Guattari e Deleuze é o quanto áreas como Filosofia e Psicologia tem muito a colaborar com os debates relacionados ao ser humano e ao meio ambiente, o que nos aponta para a relevância da interdisciplinaridade como suporte teórico e prático para uma efetiva Educação Ambiental.

No texto de Deleuze (Instintos e Instituições), breve nas palavras, mas amplo no conteúdo, mostra-se atual e oportuno para se pensar o papel compreendido pela legislação na conservação do meio ambiente, em especial, pensar o Brasil impregnado de leis que não são cumpridas. A relevância de uma democracia traduzida em instituições atuantes (a partir de uma "inteligência coletiva" e não individualista) deve ser pressuposto almejado pela Educação Ambiental.

No livro de Guattari (As Três Ecologias) é exposto um elemento indispensável à Educação Ambiental, a subjetividade como domínio ecológico, ou seja, a urgência da percepção de nós mesmos diante de padrões expostos pelo sistema capitalista que comanda nossa maneira de ser por séculos, como nas relações de gênero, exploração infantil, desculturalização das comunidades, demagogias massificantes entre outros que contribuem para o desequilíbrio individual, social e do meio ambiente.

A obra escrita por ambos (0 Que é Filosofia?) além de levar o leitor para refletir sobre diversos temas filosóficos pertinentes ao nosso mundo, nos ensina a importância de não se aceitar definições prontas e impostas, mas construir e reconstruir conceitos tendo como certa a dinâmica e a complexidade das questões ambientais.

Guattari e Deleuze nos textos lidos apresentam um longo repertório de conceitos e percepções sobre o meio ambiente que mereceriam uma análise muito mais abrangente e aprofundada pela atualidade do pensamento de ambos filósofos. Contudo, este breve trabalho procurou apontar apenas algumas "ressonâncias" refletidas por Guattari e Deleuze sobre o meio ambiente que são suficientes para indicá-los como autores fundamentais para se pensar a Educação Ambiental em nosso mundo contemporâneo.

Outros textos de Guattari e Deleuze podem ser citados com igual relevância aos apresentados e que muito podem contribuir para profícuos debates sobre questões ambientais, como O Anti-Édipo: esquizofrenia e capitalismo (1972) que denuncia o quanto o capital atua em várias dimensões na vida da sociedade determinando os seus objetivos materiais e econômicos.

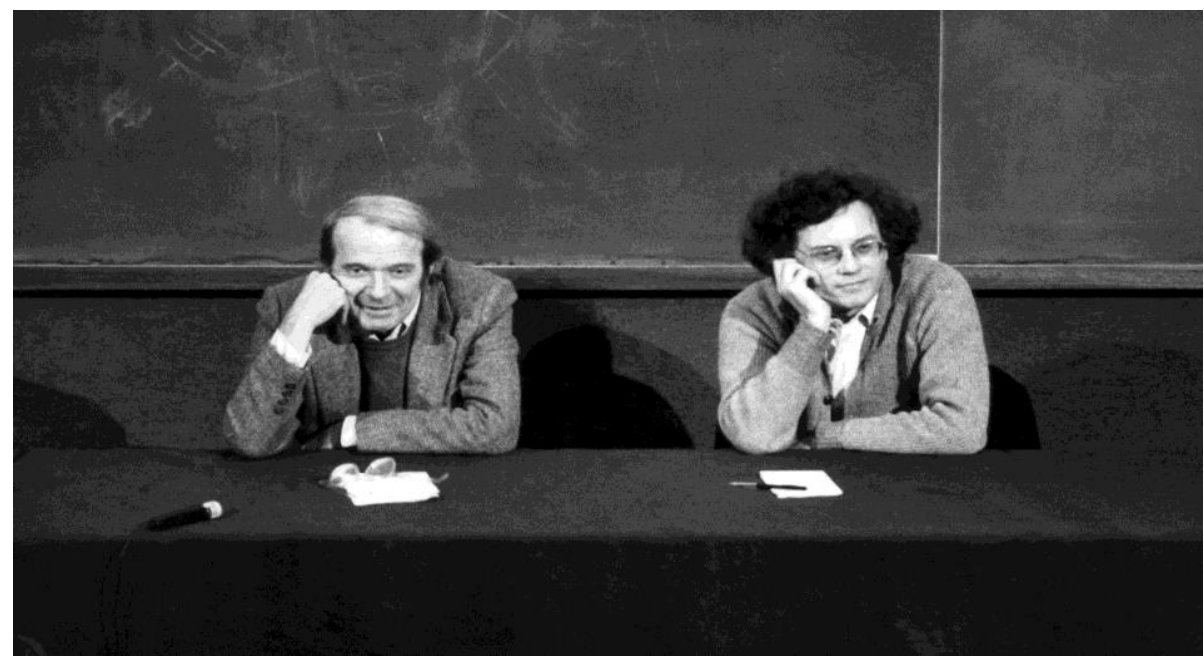




\section{REFERÊNCIAS BIBLIOGRÁFICAS}

[1] GUATTARI, Félix. As três ecologias. Campinas: Papirus, 1990. 56 p.

[2] DELEUZE, Gilles; GUATTARI, Félix. O que é Filosofia? Rio de Janeiro: Ed. 34, 1992. 288 p. (Coleção Trans)

[3] DELEUZE, Gilles. Instintos e Instituições. In: DOSSIER Deleuze. Hólon: Rio de Janeiro, 1991.

[4] NEGRI, Antonio. Deleuze e Guattari - uma filosofia para o século XXI. São Paulo: Politeia, 2018. 229 p.IMAGEM DELEUZE E GUATTARI. https://www.google.com.br/search?q=deleuze+e+guattari\&sxsrf=ALeKk0060wYsyi1S1M6xWIQWye2CwssFw:1616550860443\&source=lnms\&tbm=isch\&sa=X\&ved=2ahUKEwjT5bCe6cfvAhUkC9QK HUWTCqAQ_AUoAXoECAEQAw\&biw=1024\&bih=625\#imgrc=aQP-AuCp4qqUAM 


\section{Capítulo 2}

Desmitificar para conservar: 0 conhecimento etnoherpetológico de alunos do Ensino Fundamental II

\section{Monique Dias Benedetti \\ Luiz Fernando Ferreira \\ Ana Caroline Vitor Avelar \\ Fabiola Mangabeira Ceolato da Silva \\ Daniela Ferreira Cardoso}

Resumo: A percepção e o conhecimento da sociedade acerca da fauna estão cercados de mitos e crenças que muitas vezes podem causar malefícios aos animais, dentre estes estão os anfíbios, perigosos e asquerosos aos olhos de uma grande parcela da comunidade. Sob este contexto, este trabalho objetivou transmitir conhecimento científico acerca dos anfíbios para alunos do ensino fundamental II. Surgiu-se a ideia então de fazer uma explicação de forma mais lúdica, contextualizando primeiramente o que os alunos já tinham como conhecimento, em seguida foi feita a explicação sobre a classe Amphibia utilizando fotos de anfíbios da região e de outros não encontrados nesta, como por exemplo as salamandras. Ao final de toda explicação e desmitificação do conhecimento comum que muitas vezes é transmitido de forma errônea, foi aplicado um jogo no estilo passa ou repassa para que fosse avaliado a compreensão dos alunos a respeito do assunto ministrado. Sendo perceptível o quanto novas metodologias como essa são importantes na motivação e curiosidade dos alunos.

Palavras-chave: Anfíbio; Conservação; Divulgação ambiental; Etnobiologia. 


\section{INTRODUÇÃO}

A etnobiologia é uma área da Biologia que promove o conhecimento empírico, cultural e o diálogo entre os saberes, se consolidando cada vez mais como uma ciência, um campo de pesquisa e prática, primando a pesquisa científica através do diálogo com os envolvidos no processo, ou seja, dialogando com a sociedade (GÜLLICH, 2019). A esfera etnobiológica é composta por subáreas, tais como: (I) a etnoecologia, que permite compreender a interação da comunidade com o meio natural onde vivem (CAMARGO; de SOUZA; da COSTA, 2014); (II) a etnozoologia, que avalia o conhecimento, o comportamento e as crenças da sociedade em relação aos outros animais (ALVES; SOUTO, 2015); (III) a etnobotânica, que estuda a relação existente entre a sociedade e os vegetais, e a utilização de plantas como recursos (ROCHA; BOSCOLO; FERNANDES, 2015); dentre outros.

Essa área interdisciplinar da Biologia, e etnobiologia, é uma importante ferramenta capaz de avaliar os desafios envolvidos na conservação biocultural, pois visa a mediação entre os programas de conservação da biodiversidade e as comunidades humanas (WOLVERTON; NOLAN; AHMED, 2014). Ainda, a etnobiologia busca conciliar o desenvolvimento socioeconômico e o uso sustentável dos ecossistemas, buscando melhorar a qualidade de vida das parcelas menos favorecidas da população (JÚNIOR, 2002).

O Brasil é um país com dimensões continentais rico em recursos naturais, que possui uma megadiversidade animal segundo a Sociedade Brasileira de Zoologia (2021), entretanto, possuir uma das mais ricas biota do mundo é uma oportunidade e ao mesmo tempo um desafio no que tange a esfera da pesquisa, havendo assim muitas lacunas do conhecimento (STEHMANN; SOBRAL, 2016). O país é considerado o mais rico em diversidade de anfíbios (MAFFEI, 2010) sendo a classe composta por 1.136 espécies (das quais 1.093 são anfíbios anuros) (SEGALLA et al., 2019), entretanto, muitos mitos e crenças envolvem esse grupo, reforçando a aversão popular pelos anfíbios, que muitas vezes não apresentam ameaças reais (PAZIANATO, 2013). Nesse contexto, a etnoherpetologia proporciona o registro dos saberes populares, revelando lendas e crenças envolvendo o grupo (DIAS; LIMA; ANDRADE, 2018), oferecendo conhecimento técnico-científico para a desmitificação acerca deste táxon.

Uma forma de compreender e melhorar a interação do homem com a natureza, é investigar o conhecimento e a percepção da comunidade acerca da fauna, o que permite traçar estratégias para a conservação da biodiversidade (BARBOSA, 2007), neste contexto, este trabalho objetivou a verificação do conhecimento etnoherpetológico dos alunos do ensino fundamental II numa tentativa de desmitificar algumas crenças da sociedade acerca da fauna de anfíbios.

\section{MATERIAL E MÉTODOS}

O presente estudo foi aplicado no dia 13 de junho de 2019, para alunos de uma escola estadual de ensino

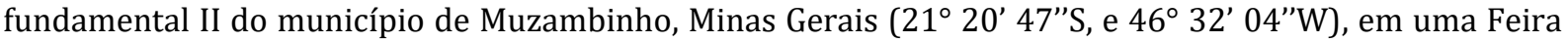
Itinerante de Biologia, organizada por professores e alunos do curso de licenciatura em Ciências Biológicas do IFSULDEMINAS campus Muzambinho, que ocorreu na praça Pedro de Alcântara Magalhães, localizada na mesma cidade.

Os alunos puderam escolher quais trabalhos expostos na feira eles gostariam de ver, a aplicação deste trabalho foi feita quatro vezes para cerca de 10 alunos por grupo, cada aplicação durou em média de 15 à 20 minutos, o que resultou em cerca de uma hora e vinte minutos de aplicação.

Inicialmente foi utilizado uma caixa de som com a vocalização de alguns anuros para chamar a atenção dos alunos que passavam pela feira, em seguida com um grupo de cerca de 10 alunos a abordagem do tema foi iniciada.

Para elaboração do material, foram selecionadas fotos representativas dos animais de cada ordem (Anura, Gymnophiona e Caudata) da classe Amphibia. As mesmas foram impressas de forma a mostrar aos alunos a grande variedade de espécies, e suas diferenças morfológicas no decorrer da explicação do assunto tratado.

Após tomar ciência do conhecimento popular (etnoherpetológico) dos alunos, foram difundidos conhecimentos científicos acerca do grupo em questão, a classe Amphibia, como o que são os anfíbios, seus representantes e esclarecimento de mitos que a sociedade costuma ter perante estes. Também foram utilizadas fotos comparativas das Gymnophionas com outros animais que os lembram morfologicamente como o Oligochaeta da espécie Rhinodrilus alatus, mais conhecido popularmente como minhocuçu e espécies do gênero Amphisbaenia para demonstração de suas diferenças. Em seguida, foram citados os danos que o aquecimento global podem e estão causando nestes animais que são bioindicadores naturais, 
e por esse e outros motivos são bastante sensíveis.

Após toda explicação, foi aplicado um jogo no qual os alunos foram separados em duas equipes, um representante de cada equipe ficou posicionado de frente ao representante da equipe adversária com a mão atrás da orelha, os mesmos ouviram a pergunta (sendo de alternativas ou de verdadeiro ou falso), após o término da leitura da pergunta os representantes puderam tocar uma campainha posicionada ao centro a partir do sinal de "Já".

Aquele que tocou a campainha primeiro, respondeu a pergunta (tendo direito a apenas uma repetição da leitura da pergunta e podendo consultar sua equipe por 15 segundos), se a resposta estivesse correta a equipe recebe um ponto, já se estiver incorreta a equipe adversária pontua, os representantes de cada equipe são trocados a cada nova pergunta independente da resposta estar correta ou não. 0 jogo foi utilizado como método de fixação do conteúdo anteriormente explicado.

\section{RESULTADOS E DISCUSSÕES}

Pode-se perceber que o som utilizado da vocalização dos anuros chamou muito a atenção dos alunos, mesmo que muitos deles não soubessem de que animal se tratava, e quando questionados sobre os anfíbios foi notório que seus conhecimentos eram fundamentados em crenças populares, ou seja, conhecimento popular e muitas vezes transmitido de forma errônea.

A herpetologia é o ramo da Biologia que estuda anfíbios e répteis, tendo-se iniciado estes estudos no Brasil em torno de 1920 por Adolpho Lutz (1855-1940) e Alípio de Miranda-Ribeiro (1874-1939) (MONTEIROFILHO et al., 2017), entretanto, nenhum dos alunos conheciam o termo, e nem sabiam que há na Biologia um ramo dedicado exclusivamente ao estudo de anfíbios e répteis.

Assim que os alunos tiveram o primeiro contato com as fotos dos anfíbios pode-se perceber a grande repulsa que a maioria apresentava diante das fotos dos animais. Esse comportamento foi observado também por Dias, Lima e Andrade (2018), no qual 37\% dos 260 alunos do ensino fundamental apresentaram nojo pelos representantes da herpetofauna.

Ao longo da explicação, foi possível desmitificar diversos conhecimentos que foram passados aos alunos de forma errônea, já que muitas vezes as informações que estes obtiveram foram transmitidas a eles pelas antigas gerações que acreditam em mitos e lendas. Uma dessas lendas abordava os anfíbios como agentes causadores de cegueira, devido ao veneno expelido por esses, sendo essa uma lenda muito popular na sociedade (MARTINS, 2009), entretanto, apenas uma espécie de anuro (Rhaebo guttatus, Schneider 1799) apresenta essa peculiaridade, sendo este restrito ao bioma amazônico (AZEVEDO-RAMOS et al., 2010), o que leva Ferrante e Veiga (2019) a crerem que essa lenda pode ter migrado para outras regiões.

Também foi possível notar, o quão surpresos os alunos ficaram ao saberem a diversidade de anfíbios mundial e mais ainda a elevada riqueza de espécies do estado de Minas Gerais, entretanto, embora ecologicamente importantes para o ecossistema (os anuros equilibram teias alimentares e ainda realizam controle de insetos transmissores de doenças) (SEGALLA et al., 2016), muitos dos alunos não tinham noção desse fato.

Durante a aplicação do jogo foi evidente a interação dos estudantes, e mesmo que algumas perguntas não tenham sido respondidas corretamente, foi demonstrado interesse em saber a resposta correta e a explicação do motivo por terem errado tal pergunta, tendo sido este um importante método de fixação do conteúdo, o que demonstrou a importância de se usar novas metodologias como essa, nas quais os alunos se sentem mais à vontade para interagir e acrescentar no decorrer das explicações.

\section{CONCLUSÕES}

A utilização deste estilo de abordagem e aplicação de jogo nos mostra a importância de se explorar novos métodos de ensino, nos quais os alunos se vêem inseridos de forma ativa no processo de ensinoaprendizagem quando agregam com seus conhecimentos prévios, se sentem motivados e interessados pelo conteúdo trabalhado. Ainda, a utilização de jogos promove a interação entre os envolvidos, interação essa muito importante, pois através dela, pode-se criar momentos de aprendizagem com muito significado aos alunos (ARAUJO, 2018). 
Tais intervenções, conforme Ferrante e Veiga (2019), podem transformar a visão estigmatizada da sociedade acerca desses animais, auxiliando na conservação do grupo e do meio ambiente como um todo. Além disso, os alunos têm a oportunidade de debater e entender os motivos que levam uma sociedade a crer em mitos sobre determinados fenômenos da natureza ou a fauna e flora, ajudando no desenvolvimento e afloramento de pessoas mais críticas e ativas em nossa sociedade.

\section{REFERÊNCIAS}

[1] ALVES, R. R. N.; SOUTO, W. M. S. Ethnozoology: a brief introduction. Ethnobiology and Conservation. v. 4, n. 1, jan $2015 . \quad$ Disponível em: <https://www.researchgate.net/publication/274567607_Ethnozoology_A_Brief_Introduction> Acesso em: 16 mar. 2021.

[2] ARAUJO, M. A. F. O jogo como atividade interativa e colaborativa na aprendizagem de inglês por alunos adolescentes de uma escola pública. Revista Humanidade e Inovação. v.5, n.1, p. 76-86, fev. 2018.

[3] AZEVEDO-RAMOS, C. Rhaebo guttatus. The IUCN Red List of Threatened Species 2010. Disponível em: <https://www.iucnredlist.org/species/54658/11183165> Acesso em: 16 mar. 2021.

[4] BARBOSA, A. R.; NISHIDA, A. K.; COSTA, E. S.; CAZÉ, A. L. R. Abordagem etnoherpetológica de São José da Mata - Paraíba - Brasil. Revista de Biologia e Ciências da Terra. Sergipe, v.7, n.,2, p. 117-123, 2007.

[5] CAMARGO, F. F.; de SOUZA, T. R.; da COSTA, R. A. Etnoecologia e etnobotânica em ambientes de Cerrado no Estado de Mato Grosso. INTERAÇÕES. Campo Grande, v. 15, n. 2, p. 352-360, jul/dez, 2014.

[6] DIAS, M. A, da S.; LIMA, N. B.; FIGUEIREDO-DE-ANDRADE, C. A. Análise do conhecimento etno-herpetológico dos estudantes no município de Salinas, Minas Gerais, Brasil. Acta Biomedica Brasiliensia, v. 9, n. 1, p. 36-47, abr. 2018.

[7] FERRANTE, L.; VEIGA, C. A visão etnoecológica que jovens em formação escolar têm sobre os anfíbios e a importância da educação ambiental para a conservação destes animais. Ethnoscientia - Brazilian Journal of Ethnobiology and Ethnoecology. v. 4, n. 1, p. 1-8, aug. 2019.

[8] GÜLLICH, R. I. da C. Reflexões acerca da Etnobiologia e etnoecologia no Brasil. Ponta Grossa: Atena Editora, 2019 .

[9] JÚNIOR , N. N. P. Etnoecologia e conservação em áreas naturais protegidas: incorporando o saber local na manutenção do Parque Nacional do Superagui. 2002. 91 f. Dissertação (Mestrado em Ecologia e Recursos Naturais) Programa de Pós-Graduação da Universidade Federal de São Carlos, São Carlos, 2002.

[10] MAFFEI, F. Diversidade e uso do habitat de comunidades de anfíbios anuros em Lençóis Paulistas, Estado de São Paulo. 2010. 85 f. Dissertação (Mestrado em Zoologia)-Programa de Pós Graduação, Faculdade de Ciências Biológicas da Universidade Estadual Paulista, Botucatu, 2010.

[11] MARTINS, F. Anfíbios: uma vida dupla de adoração e discriminação. 2009. Disponível em: <http://naturlink.pt/article.aspx?menuid=80\&cid=51219\&bl=1\&viewall=true> Acesso em: 16 mar. 2021.

[12] MONTEIRO-FILHO, E.L.A.; CONTE, C.E. Revisões em zoologia: Mata Atlântica. 1.ed. Curitiba: UFPR, 2017.

[13] PAZIANATO, D. M. M. Estudo etnoherpetológico: conhecimentos populares sobre anfíbios e répteis no município de Caçapava do Sul, Rio Grande do Sul. 2013. 66 f. Monografia (Especialização em Educação Ambiental) Universidade Federal de Santa Maria, Santa Maria, 2013.

[14] ROCHA, J. A.; BOSCOLO, O. H.; FERNANDES, L. R. R. de M. V. Etnobotânica: um instrumento para valorização e identificação de potenciais de proteção do conhecimento tradicional. INTERAÇõES. Campo Grande, v. 16, n. 1, p. 67-74, jan./jun. 2015.

[15] SBZ. Catálogo Taxonômico da Fauna Brasileira da Fauna Brasileira (CTFB). 2021. Disponível em: \&lt;http://sbzoologia.org.br/catalogo-taxonomico.php\&gt; Acesso em: 27. jan. 2021.

[16] SEGALLA, M. V. Et al. Brazilian Amphibians: List of species. Herpetologia Brasileira. Belo Horizonte. v.5, n.2, p. 34-46, jul. 2016.

[17] SEGALLA, M. v. et al. Brazilian Amphibians: List of species. Herpetologia Brasileira. Belo Horizonte. v.8, n.1, p. 65-97, abr. 2019.

[18] STEHMANN, J. R.; SOBRAL, M. Biodiversidade no Brasil. In: SIMÕES, C. M. O. et al (Org) Farmacognosia: Do Produto Natural ao Medicamento. 1. Ed. Artmed, 2016.

[19] WOLVERTON, S.; NOLAN, J. M.; AHMED, W. Ethnobiology, political ecology and conservation. Journal of Ethnobiology. v. 34, n. 2, p. 125-152, 2014. 


\section{Capítulo 3}

Estado de conservação e potencial da regeneração natural para restauração de áreas antropizadas no noroeste do Rio Grande do Sul

\section{Adriana Maria Griebeler}

\section{Felipe Turchetto}

Resumo: 0 presente estudo teve como objetivo realizar uma revisão bibliográfica sobre o estado de conservação e o potencial da regeneração natural para restauração de áreas antropizadas no Noroeste do Rio Grande do Sul. A Região Noroeste do RS é uma das áreas mais recentemente ocupadas por colonizadores, caracteriza-se pelo domínio da pequena propriedade rural e desenvolvimento de lavouras com caráter comercial principalmente de trigo, milho e soja. A constante degradação causada pela colonização, ação antrópica com a exploração de recursos florestais predatória, desenvolvimento de atividades agropecuárias com expansão das áreas agrícolas e das áreas urbanas, bem como estabelecimento de locais voltados ao lazer como casas de veraneio, acampamentos e balneários gerou áreas altamente fragmentadas. Devido as características da região o processo de regeneração natural torna-se uma estratégia potencial a ser analisada considerando como forma de restauração mais ecológica, econômica e de fácil aceitação pelos produtores rurais, além de estar prevista na Legislação Florestal brasileira. Diante do exposto, destaca-se a importância da elaboração de projetos, incentivado por políticas públicas com vistas a formação de corredores ecológicos, interligando os fragmentos que se encontram isolados e ações com foco na restauração florestal, reflorestamentos e desenvolvimento de sistemas agroflorestais, todos buscando ampliar a cobertura florestal natural do Estado, bem como fiscalização de áreas que apresentam propensão a expansão das fronteiras agrícolas no Noroeste do RS.

Palavras-chave: Biodiversidade, Cobertura Florestal, Fragmentação florestal, Mata Atlântica. 


\section{INTRODUÇ̃̃OO}

As formações vegetais da Mata Atlântica possuem grande importância ecológica por apresentarem elevada riqueza e diversidade de espécies, sendo abrigo de significativa quantidade de espécies endêmicas (LEITÃO FILHO et al., 1993) e servindo como importantes centros de biodiversidade do planeta. Dentre suas tipologias, no Estado do Rio Grande do Sul, a Floresta Estacional Decidual (FED) se sobressai como o tipo florestal predominante estando presente ao longo das regiões noroeste e central do Rio Grande do Sul (KILCA; LONGHI, 2011).

Historicamente a Região Noroeste do Estado do Rio Grande do Sul era coberta por vastas florestas, no entanto, com a chegada dos imigrantes europeus, a partir do final do século XIX, houve grande devastação com a abertura de caminhos para a ocupação e a intensificação do processo de colonização (MANTELLI, 2009). Esse processo se agravou com a constante degradação causada pela ação antrópica, com a exploração de recursos florestais predatória (IBGE, 1995), expansão das áreas agrícolas e urbanas, bem como estabelecimento de locais voltados ao lazer, como casas de veraneio, acampamentos e balneários (AFONSO et al., 2013).

Tais processos acarretaram na fragmentação da paisagem florestal, redução da área de habitats disponíveis e isolamento de populações, o que representa uma das ameaças mais sérias à perda de biodiversidade (METZGER, 2006; CALMON et al., 2011). A fragmentação florestal pode interferir na conservação das espécies da fauna e flora local e na distribuição da variabilidade genética entre e dentro das populações, sendo que esta situação é ainda mais agravada em áreas que se localizam perto de áreas urbanizadas ou em processo de urbanização devido à pressão antrópica que as cidades exercem sobre estes fragmentos florestais remanescentes (FISZON et al., 2003). A fragmentação florestal tende a gerar populações reduzidas e isoladas reprodutivamente. Com isso, pode haver um nível mais elevado de endogamia, podendo gerar depressão endogâmica (FRANKHAM et al., 2002).

A intensa devastação e fragmentação levou a uma grande redução na cobertura florestal no Rio Grande do Sul, que inicialmente correspondia a cerca de $40 \%$ do território, e foi reduzida a $15 \%$, segundo dados do inventário florestal contínuo do RS realizado em 2018 (SFB, 2018). No entanto, indícios promissores mostram que mundialmente essas taxas de desmatamento vêm declinando paulatinamente devido ao incremento das taxas de reflorestamento e regeneração florestal natural (CHAZDON, 2012), bem como redução do desmatamento evidenciado na Mata Atlântica, também observada no Rio Grande do Sul (FUNDAÇÃO SOS MATA ATLÂNTICA; INPE, 2019).

Nas últimas décadas, conforme Hendges et al. (2012), observa-se um aumento da cobertura florestal, sobretudo no noroeste do estado do Rio Grande do Sul. Além disso, evidencia-se aumento do tamanho dos remanescentes, apesar destes estarem bastante fragmentados em termos de cobertura florestal, assim como o processo de recuperação natural de muitas áreas, devido a mudanças tecnológicas na agricultura, à realidade demográfica da região e à conscientização ambiental (ROSA, et al., 2017). Adicionalmente, fatores como o uso inadequado e a falta de manejo em áreas com solos de baixas produtividades contribui para o abandono dessas áreas e consequentemente ao êxodo rural (CECONI, 2007).

De acordo com Kageyama e Gandara (2003), é essencial o desenvolvimento de técnicas e processos que viabilizem e garantam a restauração, considerando o quadro de devastação da Mata Atlântica. Assim, diversas metodologias têm sido desenvolvidas (MARTINS, 2007; MARTINS et al., 2007; TURCHETTO et al., 2016; TURCHETTO et al., 2020), tendo como principal enfoque a restauração da diversidade vegetal, funções e processos ecológicos dos ecossistemas sem a preocupação com o clímax final a ser alcançada (MARTINS et al., 2012).

Consoante a isso, é fundamental a adoção de técnicas de restauração adequadas a realidade de cada área, frente à grande demanda imposta pela necessidade de regularização das propriedades rurais. Nesse sentido, a condução da regeneração natural torna-se uma estratégia potencial a ser analisada, desde que haja disponibilidade de banco de sementes e a dispersão seja facilitada ao longo do tempo (COELHO, 2010), visto que trata-se da forma de restauração mais ecológica, econômica e de fácil aceitação pelos produtores rurais (MARTINS et al., 2014). A técnica de condução da regeneração natural está prevista na Legislação Florestal Brasileira como uma das possíveis formas de recompor a vegetação nativa, podendo ser aplicada de forma isolada ou conjuntamente com outros métodos, como plantio de mudas por exemplo (BRASIL, 2012).

Segundo Sartorelli e Campos Filho (2017), a regeneração natural pode ser conduzida de duas maneiras, de forma passiva (isolamento) ou ativa (manejo adaptativo). A regeneração natural passiva prevê apenas o isolamento dos fatores de perturbação e é recomendada para situações em que forem observados valores 
altos de densidade (quantidade de plantas/hectare) e riqueza (quantidade de espécies nativas), sem plantas invasoras e solo exposto. Já o manejo adaptativo é indicado para casos em que há valores intermediários de densidade e riqueza de regenerantes e consiste na adoção de intervenções que propiciarão o desenvolvimento da regeneração natural, garantindo aumento desses parâmetros e cobertura com espécies nativas. Conforme os autores, algumas das atividades possíveis a serem desenvolvidas no manejo adaptativo estão o isolamento da área contra os fatores de degradação, controle de plantas invasoras, nucleação com instalação de poleiros, torres de cipó, enriquecimento com mudas adensadas em ilhas, enleiramento de galharias, coroamento e adubação de regenerantes, enriquecimento com plantio de sementes.

Diante do exposto, destaca-se a imprescindibilidade do estudo e condução da regeneração natural para a restauração de áreas que necessitam ser restauradas. Assim, o presente trabalho teve como objetivo realizar uma revisão bibliográfica sobre o estado de conservação e o potencial da regeneração natural para restauração de áreas antropizadas no Noroeste do Rio Grande do Sul.

\section{METODOLOGIA}

0 presente artigo baseia-se em estudos e levantamentos de dados, obtidos por meio de pesquisas bibliográficas em artigos, monografias, teses e dissertações sobre o estado de conservação e o potencial da regeneração natural para restauração de áreas antropizadas no Noroeste do Rio Grande do Sul.

\section{DESENVOLVIMENTO}

\subsection{CARACTERIZAÇÃO DA ÁREA DE ESTUDO}

A Região Noroeste do RS é uma das áreas mais recentemente ocupadas por colonizadores e descendentes de antigos colonos de origem europeia (Figura 1). Constituída por 216 municípios a região caracteriza-se pelo domínio da pequena propriedade rural com produção de alimentos destinados à subsistência familiar, bem como desenvolvimento de lavouras com caráter comercial dada principalmente pela produção de trigo, milho e soja (MANTELLI, 2006).

Figura 1- Localização da região noroeste do Estado do Rio Grande do Sul, Brasil.

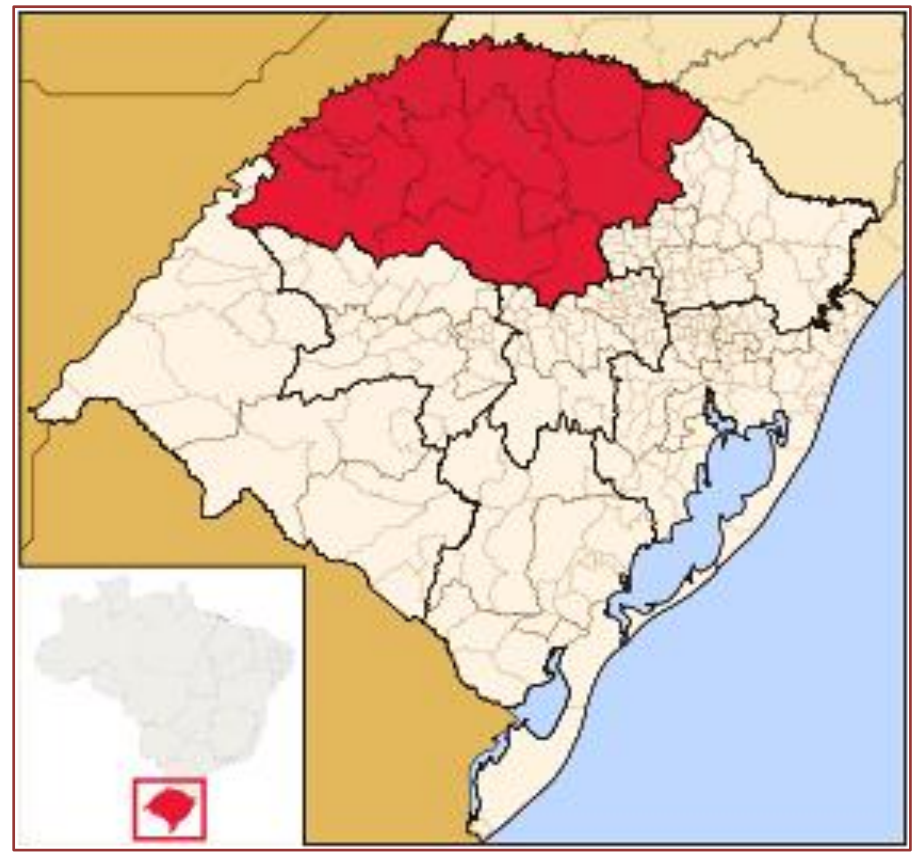

Fonte: IBGE (2021). 
Em virtude da presença de elementos geográficos e naturais marcantes como o Rio Uruguai e o Parque Estadual do Turvo, a região é caracterizada pelas belezas naturais, o que favorece o estabelecimento de práticas e locais voltados ao lazer, como acampamentos, balneários, e visitas de turistas.

O clima da região é do tipo Subtropical (Cfa), caracterizado por temperaturas variando de $3^{\circ} \mathrm{C}$ para o mês mais frio e $22^{\circ} \mathrm{C}$ para o mês mais quente (ALVARES et al., 2013). De acordo com o sistema brasileiro de classificação de solos, os solos predominantes na região são do tipo Latossolo Vermelho Distroférrico (EMBRAPA, 2013).

Quanto ao relevo, a região apresenta formas com variações bem distintas que refletem na ocupação do solo, possuindo áreas com planícies agricultáveis, terrenos levemente ondulados que evoluem para fortemente ondulado à medida que se se aproxima do Rio Uruguai. Nesta área o relevo torna-se mais íngreme com declividade acentuada.

A vegetação da região faz parte da Floresta Estacional Decidual, a qual se caracteriza pela deciduidade do componente arbóreo, determinada pela sazonalidade climática e por variações ambientais locais (LEITE; KLEIN, 1990). Tomando como base essa característica da tipologia, no Estado, a mesma foi recentemente redefinida por Schumacher et al. (2011) como Floresta Estacional Subtropical, pelo fato da queda das folhas do estrato superior ocorrer em virtude das baixas temperaturas no inverno, e não pelo déficit hídrico, como na região central do Brasil.

Estas florestas foram constantemente exploradas desde o início da colonização do país, cujo impacto da exploração era mínimo devido à baixa concentração demográfica (MEYER, 2008). 0 aumento da população e o desenvolvimento de novas tecnologias de utilização da madeira, aliados ao crescimento do comércio e circulação desses produtos e a constante busca por novas áreas, favoráveis a atividade agrícola e pecuária, fez com que as florestas sofressem drásticas mudanças na sua estrutura original (HACK, 2007), reduzindo os maciços florestais a florestas fragmentadas, comprometendo a manutenção da diversidade biológica e a conservação destes locais (LONGHI et al., 1999).

Atualmente, observa-se uma redução no desmatamento no Bioma Mata Atlântica. Conforme dados publicados recentemente pela Fundação SOS Mata Atlântica em parceria com Instituto Nacional de Pesquisas Espaciais, o estado do Rio Grande do Sul está próximo ao nível do desmatamento zero (com desflorestamentos abaixo de 100 hectares), contabilizando 171 hectares desmatadas entre 2017-2018, em relação a 201 hectares registrados em 2016-2017 (FUNDAÇÃO SOS MATA ATLÂNTICA; INPE, 2019).

Paralelamente, a evolução da cobertura vegetal na região é atribuída ao avanço da regeneração natural em áreas mais íngremes, ocasionado principalmente pelo abandono causado pela modernização da agricultura e êxodo rural (ANDRAE; SCHINEIDER; DURLO, 2018). Hendges; Pereira; Andres (2012) ao utilizar um modelo de simulação para verificar a evolução das áreas florestais nativas no Rio Grande do Sul observaram uma continuidade em relação ao padrão de uso da terra que vem sendo adotado nos últimos anos no Estado, sobretudo na Região Noroeste, sendo que o aumento das áreas de floresta nativa apresenta um crescimento proporcional com o passar dos anos até 2020, como pode ser observado na figura 2 .

A Terra Indígena da Guarita possui uma extensão de 23.407 hectares, abrangendo os municípios de Redentora, Tenente Portela e Erval Seco. Já a Terra Indígena de Nonoai ocupa uma área de 19.830 hectares (BREUNIG et al., 2015). Estudos realizados por Conte et al. (2013) e Rosa et al. (2017) demonstraram que a região apresenta predomínio da classe florestal, no que se refere a cobertura e ocupação do solo, com percentual variando de $46 \%$ a $50 \%$. Nesse sentido, deve-se dar destaque a presença das Reservas Indígenas e do Parque Estadual do Turvo, os quais representam extensos maciços de florestas nativas (Figura 3), sendo essenciais à manutenção de fluxo gênico e a garantia de perpetuação de espécies animais em especial as de ocorrência endêmica (CONTE et al., 2013). 
Figura 2 - Distribuição das novas áreas de floresta nativa simuladas para 2020.

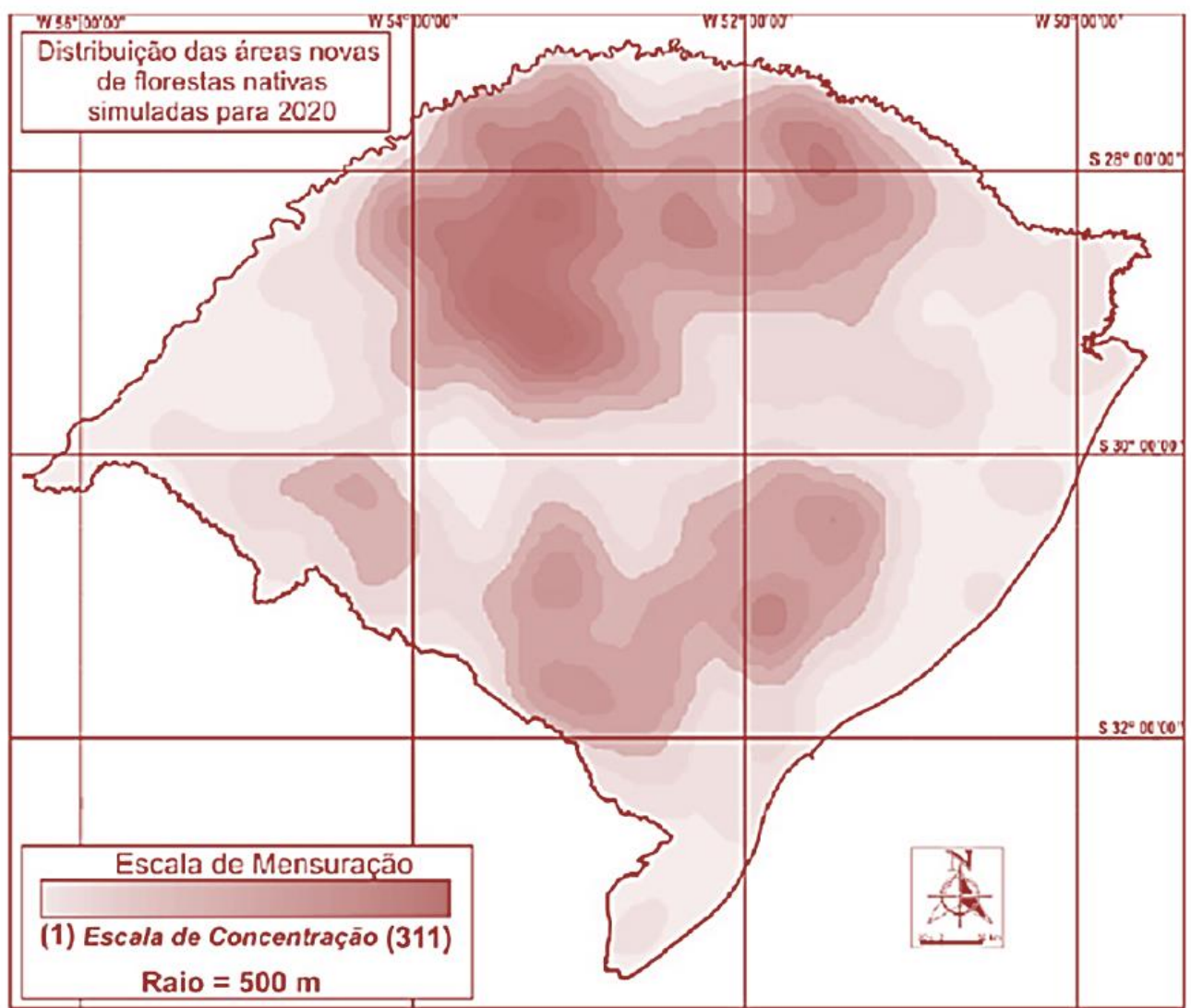

Fonte: Hendges; Pereira; Andres (2012).

Figura 3 - Localização do Parque Estadual do Turvo e das Reservas Indígenas de Nonoai e do Guarita.

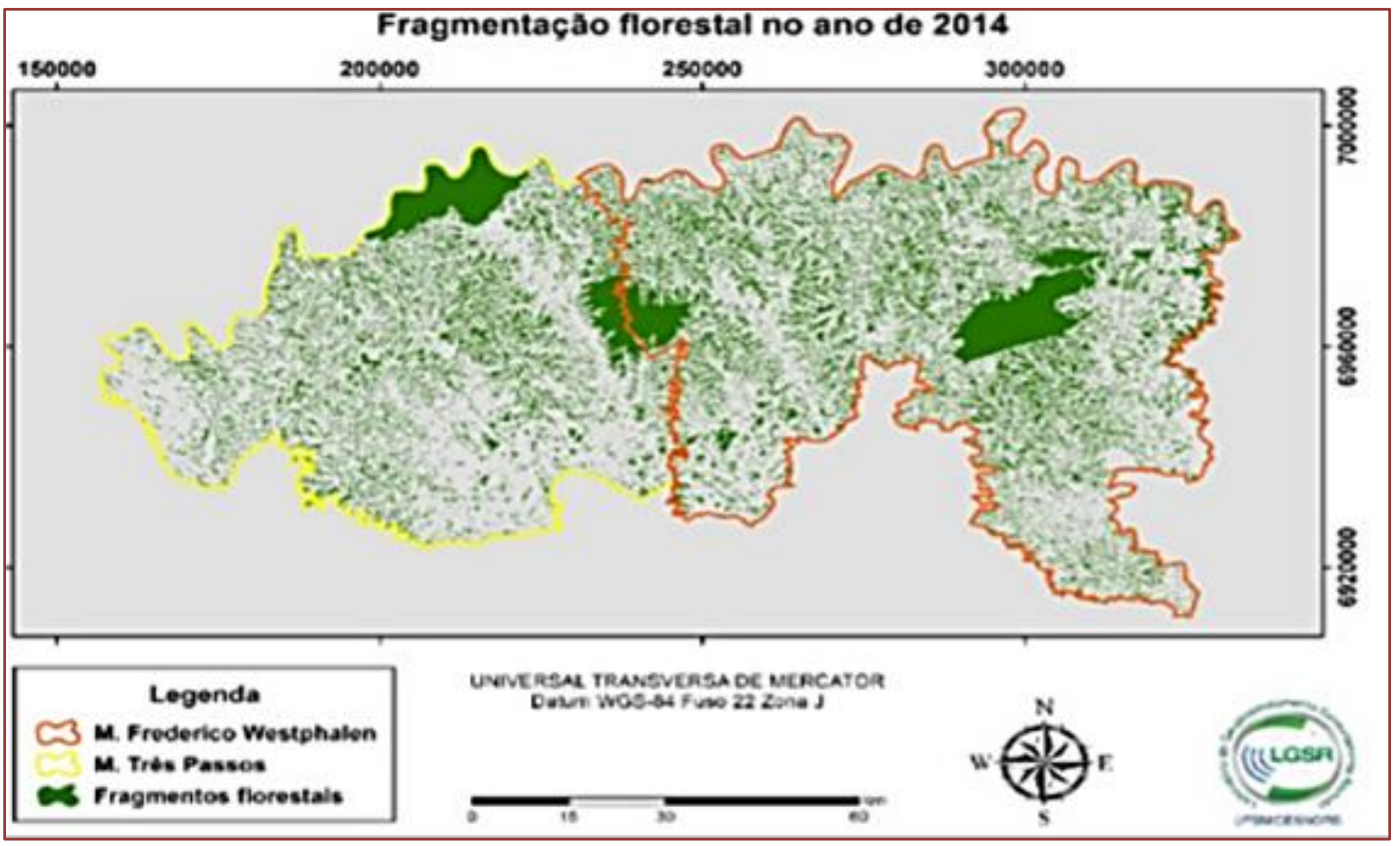

Fonte: Rosa et al. (2017). 


\subsection{A REGENERAÇÃo NATURAL COMO METOdOLOGIA POTENCIAL PARA RESTAURAÇÃO FLORESTAL}

As diferentes técnicas de restauração podem estar centradas no potencial de resiliência natural do ecossistema, com mínima interferência antrópica, tais como a nucleação (topsoil, transposição da serapilheira, de galharia, chuva de sementes e uso de poleiros naturais e artificiais), semeadura direta, transplante de plântulas e condução da regeneração natural (BRANCALION et al., 2009). Por outro lado, outras aceleram a recuperação mediante o plantio de mudas de espécies arbóreas nativas, combinando diferentes grupos ecológicos (pioneiras e não pioneiras) e funcionais (leguminosas e não leguminosas) (CAMPOE et al., 2015; RODRIGUES et al., 2009; TURCHETTO et al., 2020).

A visão contemporânea de restauração dá enfoque a restauração da diversidade vegetal, funções e processos ecológicos dos ecossistemas, assim estudos e procedimentos baseados nos aspectos da regeneração natural, vem ao encontro das questões de qualidade da restauração bem como sua aplicabilidade, bem como facilidade de aceitação por parte dos produtores rurais (MARTINS, 2014). Segundo Gama et al. (2002) a regeneração natural decorre da interação de processos naturais de restabelecimento do ecossistema florestal. Para Magnago et al. (2012), a regeneração natural é ferramenta importante para a restauração florestal, principalmente para grandes áreas geográficas, onde os métodos de plantio e outros podem ser inviáveis devido aos elevados custos financeiros.

Assim, considerando-se que o processo de regeneração natural é o método mais simples e barato de recuperação da vegetação, pela sucessão ecológica, desde que haja disponibilidade de banco de sementes e a dispersão seja facilitada ao longo do tempo (COELHO, 2010), esta mostra-se como alternativa potencial a ser analisada em projetos de recuperação de áreas alteradas no Noroeste do RS, combinada com técnicas complementares quando necessário. Tal fato deve ser analisado juntamente com a observação da oferta de propágulos e banco de sementes, histórico de uso da área, presença de dispersores, exposição do solo, condicionamento do substrato e presença de espécies problemas (MARTINS et al., 2012), ou seja, caso a caso.

Sartorelli e Campos Filho (2017), destacam que o monitoramento frequente dos projetos de restauração a partir da regeneração natural é essencial, pois permite avaliar e realizar o manejo adaptativo sobre os fatores limitantes que possam inibir ou retardar a evolução da regeneração natural, tal como formigas, plantas invasoras, cipós, plantas dominantes, entre outros. Os autores supracitados elencam as seguintes espécies como sendo plantas invasoras ou oportunistas agressivas que podem retardar ou impedir a regeneração natural da Mata Atlântica: capins braquiária (Brachiaria spp.), o capim colonião (Panicum maximum), o capim-gordura (Melinis minutiflora), o samambaiaçu-bravo (Pteridium aquilinum), o bambulistrado (Bambusa vulgaris), a leucena (Leucaena leucocephala), o ipê-de-jardim (Tecoma stans) e alguns cipós em áreas de solo bem drenado, além do lírio-do-brejo (Hedychium coronarium) e taboa (Typha angustifolia) que invadem solos brejosos.

No quadro 1, é possível observar o potencial da regeneração natural diante diferentes formas de perturbação/degradação em áreas pertencentes ao Bioma Mata Atlântica e as técnicas de restauração passíveis de utilização.

Quadro 1- Potencial da regeneração natural diante diferentes formas de perturbação/degradação em áreas pertencentes ao Bioma Mata Atlântica e as técnicas de restauração passíveis de utilização

\begin{tabular}{|c|c|c|}
\hline \multirow{3}{*}{ Processo de Perturbação } & Potencial de & \multirow{3}{*}{ Técnica de Restauração } \\
\hline & Regeneração & \\
\hline & Natural & \\
\hline Desmatamento & Alto & $\begin{array}{l}\text { - } \quad \text { Prevenção de incêndios } \\
\text { - } \quad \text { Controle de espécies invasoras }\end{array}$ \\
\hline $\begin{array}{l}\text { Povoamentos florestais } \\
\text { com árvores exóticas }\end{array}$ & Médio a alto & $\begin{array}{ll}\text { - } & \text { Eliminação de árvores exóticas; } \\
\text { - } & \text { Prevenção de incêndios } \\
\text { - } & \text { Controle de espécies invasoras }\end{array}$ \\
\hline Queimada & $\begin{array}{l}\text { Médio a } \\
\text { baixo }\end{array}$ & $\begin{array}{ll}\text { - } & \text { Prevenção e controle de incêndios } \\
\text { - } & \text { Manejo de espécies invasoras } \\
\text { - } & \text { Plantio de enriquecimento }\end{array}$ \\
\hline
\end{tabular}


Quadro 1- Potencial da regeneração natural diante diferentes formas de perturbação/degradação em áreas pertencentes ao Bioma Mata Atlântica e as técnicas de restauração passíveis de utilização(Continuação)

\begin{tabular}{|c|c|c|}
\hline \multirow{3}{*}{ Processo de Perturbação } & Potencial de & \multirow{3}{*}{ Técnica de Restauração } \\
\hline & Regeneração & \\
\hline & Natural & \\
\hline $\begin{array}{l}\text { Pastagem com } \\
\text { remanescentes florestais } \\
\text { nativos no entorno }\end{array}$ & Médio a alto & $\begin{array}{l}\text { - } \quad \text { Suspensão de roçadas } \\
\text { - } \quad \text { Construção de cercas para isolamento do gado } \\
\text { - } \quad \text { Manejo de espécies invasoras } \\
\text { - } \quad \text { Pode ser necessária a descompactação do solo e instalação de } \\
\text { núcleos de mudas, galharias e poleiros }\end{array}$ \\
\hline $\begin{array}{l}\text { Pastagem distante } \\
\text { remanescentes florestais } \\
\text { nativos }\end{array}$ & Muito baixo & $\begin{array}{ll}\text { - } & \text { Suspensão de roçadas } \\
\text { - } & \text { Construção de cercas para isolamento do gado } \\
\text { - } & \text { Prevenção de incêndios } \\
\text { - } & \text { Manejo de espécies invasoras } \\
\text { - } & \text { Descompactação do solo } \\
\text { - } & \text { Plantio de espécies nativas por mudas ou semeadura direta. }\end{array}$ \\
\hline Lavoura & Muito baixo & $\begin{array}{l}\text { - } \quad \text { Provavelmente será necessário o manejo de espécies } \\
\text { - } \quad \text { invasoras } \\
\text { - } \quad \text { Plantio de espécies nativas por mudas ou semeadura direta } \\
\text { - Alternativa em Reserva Legal: agrossilvicultura }\end{array}$ \\
\hline $\begin{array}{l}\text { Áreas com retirada da } \\
\text { camada superficial do solo }\end{array}$ & Nulo & $\begin{array}{l}\text { - } \quad \text { Recuperação da qualidade física, química e biológica do solo } \\
\text { Transposição de solo com raízes e rizomas de áreas de } \\
\text { supressão próximas ou plantio de espécies tolerantes às } \\
\text { condições do solo e adubos verdes } \\
\text { - Inoculação do solo com micorrizas e rizóbios }\end{array}$ \\
\hline $\begin{array}{l}\text { Aterros e mineração } \\
\text { próximos à remanescente } \\
\text { florestal }\end{array}$ & Nulo & $\begin{array}{l}\text { - } \quad \text { Recuperação da qualidade física, química e biológica do solo } \\
\text { - } \quad \text { Nucleação e técnicas para atrair a fauna } \\
\text { - } \quad \text { verdestio de espécies tolerantes às condições do solo e adubos- } \\
\text { - Uso de silvicultura intensiva } \\
\text { - Inoculação do solo com micorrizas e rizóbios }\end{array}$ \\
\hline $\begin{array}{l}\text { Aterros e mineração } \\
\quad \text { distantes de } \\
\text { remanescente florestal }\end{array}$ & Nulo & $\begin{array}{l}\text { - Transposição de solo com raízes de áreas de supressão } \\
\text { próximas }\end{array}$ \\
\hline
\end{tabular}

Fonte: Adaptado de Durigan et al (2011) e Sartorelli e Campos Filho (2017).

De forma complementar, ressalta-se a importância do isolamento da área em processo de restauração com construção de cercas, assim como realizado para outras metodologias (tal como o plantio de mudas) (RORATO et al., 2018), pois barra o acesso de gado e/ou define os limites entre as áreas de restauração e as áreas agrícolas. Essa prática, apesar de apresentar custo adicional é muito importante, pois evita a compactação do solo, bem como impede que os regenerantes sejam ingeridos, pisoteados ou ainda injuriados por herbicidas quando existentes em áreas adjacentes a lavouras.

0 potencial da região noroeste para uso da regeneração natural como estratégia para a restauração de áreas alteradas é corroborado por diversos estudos relacionados a dinâmica da vegetação ao longo dos anos, os quais tem demonstrado o aumento da área de florestas com o passar do tempo (CONTE et al., 2013; ERTHAL et al., 2018; ROSA et al., 2017). Desse modo, pode-se inferir que áreas próximas a remanescentes florestais nativos quando abandonadas e cercadas, tendo os fatores de degradação retirados, tendem a iniciar o processo de restauração florestal de forma passiva, por meio da regeneração natural. 


\section{CONSIDERAÇÕES FINAIS}

A região noroeste do estado do Rio Grande do Sul apresenta elevada taxa de fragmentação dos remanescentes florestais nativos. Contudo, a presença do Parque Estadual do Turvo e das Terras Indígenas do Guarita e de Nonoai elevam a proporção de florestas nativas da região, denotando a importância de áreas naturais protegidas em Unidades de Conservação, juntamente com as Terras Indígenas, como mecanismos à conservação da biodiversidade e ao manejo sustentável dos ecossistemas.

Por outro lado, faz-se necessário o desenvolvimento de programas, projetos e ações com foco na restauração florestal, reflorestamentos e desenvolvimento de sistemas agroflorestais, todos buscando ampliar a cobertura florestal natural do Estado. É de fundamental importância a elaboração de projetos, sobretudo incentivado por políticas públicas com vistas a formação de corredores ecológicos, interligando os fragmentos que se encontram isolados, ofertando abrigo e alimento à fauna silvestre, possibilitando trocas gênicas e a conservação da diversidade (fauna e flora).

Destaca-se também a necessidade de intervenções de âmbitos participativo e educativo junto aos proprietários lindeiros ao Rio Uruguai, buscando melhores alternativas para as áreas que ainda não foram isoladas e/ou abandonadas ou que apresentam dificuldades quanto ao estabelecimento da sucessão secundária inicial.

Nota-se uma tendência no aumento das áreas em restauração devido a modernização da agricultura e consequentemente abandono de áreas marginais, no entanto é necessário que seja intensificada a fiscalização de áreas que apresentam propensão a expansão das fronteiras agrícolas.

\section{REFERÊNCIAS BIBLIOGRÁFICAS}

[1] AFONSO, M. A. et al. Adesão dos proprietários rurais ao projeto de recuperação das áreas de preservação permanente do Rio Uruguai no Noroeste do RS. In: VI Encontro Regional Sul de Ensino de Biologia, 2013, Santo Ângelo. Anais... Santo Ângelo: EREBIO-SUL, 2013. Disponível em: http://santoangelo.uri.br/erebiosul2013/anais/wpcontent/uploads/2013/07/poster/13301_256_Marcos_Antonio_Afonso.pdf. Acesso em 30 março de 2021.

[2] AlvareS, C. A.; STAPE, J. L.; SENTElHAS, P. C.; GONÇALVES, J. L. M.; Sparovek G. Köppen's climate classification map for Brazil. Meteorologische Zeitschrift, v. 22, n. 6, p. 711-728, 2013.

[3] ANDRAE, F. H.; SCHENEIDER, P. R.; DURLO, M. A. Importância do manejo de florestas nativas para a renda da propriedade e abastecimento do mercado madeireiro. Ciência Florestal. v. 28, n. 3, p. 1293-1302, 2018.

[4] BRANCALION, P. H. S.; ISERNHAGE, I.; GANDOLFII, S.; RODRIGUES, R. R. Fase 2: Plantio de árvores nativas brasileiras fundamentada na sucessão florestal. In: RODRIGUES, R. R.; BRANCALION, P. H. S.; ISERNHAGEN, I. Pacto pela restauração da Mata Atlântica: referencial dos conceitos e ações de restauração florestal. 1. ed. São Paulo: LERF/ESALQ: Instituto BioAtlântica, 2009. v. 1. p. 14-23.

[5] BRASIL. Lei no 12.651, de 25 de maio de 2012. Institui o novo Código Florestal. Diário Oficial da União, Brasília, DF, $25 \quad$ maio. $2012 . \quad$ Disponível $\quad$ em:< http://www.planalto.gov.br/ccivil_03/_Ato20112014/2012/Lei/L12651.htm\#art83>. Acesso em 16 de março de 2021.

[6] BREUNIG, F. M.; GALVÃO, L. S.; SANTOS, J. R.; GITELSON, A. A.; MOURA, Y. M.; TELES, T. S.; GAIDA, W. Spectral anisotropy of subtropical deciduous forest using MISR and MODIS data acquired under large seasonal variation in solar zenith angle. International Journal of Applied Earth Observation and Geoinformation, v. 35, p. 294-304, 2015.

[7] CALMON, M.; BRANCALION, P. H. S.; PAESE, A.; ARONSON, J.; CASTRO, P.; SILVA, S.C.; RODRIGUES, R.R. Emerging threats and opportunities for large-scale ecological restoration in the atlantic forest of Brazil. Restoration Ecology, v.19, p. 154-158, 2011.

[8] CECONI, D. E. Dossiê de ambiência e transição agroecológica no manejo da Microbacia Hidrográfica do Lajeado Biguá, Alecrim-RS. 2007. 131 p. Dissertação (Mestrado em Ciência do Solo) - Universidade Federal de Santa Maria, Santa Maria, RS, 2007.

[9] CHAZDON, R. Regeneração de florestas tropicais. Boletim do Museu Paraense Emílio Goeldi, v. 7, n. 3, p. 195218, 2012.

[10] COELHO, G. C. A floresta nativa do Noroeste do RS - questões relevantes para conservação. Caderno de Pesquisa série Botânica, Santa Cruz do Sul, v. 12, n. 1, p. 17-44, 2000.

[11] CONTE, B.; PERTUZZATTI, A.; CONTE, S.; TURCHETTO, F. Análise espaço temporal do uso do solo de parte da bacia hidrográfica do Rio da Várzea nos anos de 1985, 1996 e 2010, RS, Brasil. Enciclopédia Biosfera, Goiânia, v.9, n. 16, p. 215-223, 2013. 
[12] DURIGAN, G.; MELO, A.G.C. de; MAX, J.C.M.; CONTIERI, W.A.; RAMOS, V.S. Manual para recuperação da vegetação de cerrado. São Paulo: SMA. 2011.19 p.

[13] EMPRESA BRASILEIRA DE PESQUISA AGROPECUÁRIA - EMBRAPA. Sistema brasileiro de classificação de solos. 3.ed. Brasília, 2013. 353p.

[14] ERTHAL, D. A.; BREUNIG, F. M.; BALBINOT, R.; ROSA, P. A.; MELLO, L. F. Dinâmica da cobertura florestal da terra indígena do Guarita, RS, Brasil. Revista Brasileira de Geografia Física, v. 11, p. 2160-2172, 2018.

[15] FISZON, J. T. et al. Causas Antrópicas - 03. In: RAMBALDI, D. M.; OLIVEIRA, D. A. S. de (Orgs.). Fragmentação de Ecossistemas: Causas, efeitos sobre a biodiversidade e recomendações de políticas públicas Brasília: MMA/SBF, p. 65- 99, 2003.

[16] FRANKHAM, R.; BALLOU, J. D.; BRIDGE, D. A. Introduction to Conservation Genetics. Cambridge: Cambridge University Press, 2002.

[17] FUNDAÇÃO SOS MATA ATLÂNTICA; INSTITUTO NACIONAL DE PESQUISAS ESPACIAIS - INPE. Atlas dos Remanescentes Florestais da Mata Atlântica. Relatório Técnico: Período 2017-2018. São Paulo, 2019.

[18] GAMA, J. R. V.; BOTELHO, S. A.; BENTES-GAMA, M. de M. Composição florística e estrutural da regeneração natural de floresta secundária de várzea baixa no estuário amazônico. Revista Árvore, Viçosa-MG, v. 26, n. 5, p. 559$566,2002$.

[19] HACK, C. Respostas da vegetação remanescente e da regeneração natural em uma Floresta Ombrófila Mista cinco anos após intervenções de manejo. 2007.97 f. Dissertação (Mestrado em Engenharia Florestal) - Universidade Federal de Santa Maria, Santa Maria, 2007.

[20] HENDGES, E. R.; PEREIRA, R. S.; ANDRES, J. Dinâmica das áreas de floresta nativa no Rio Grande do Sul no período de 1988 a 2020. Ciência Rural, v. 42, n. 5, p. 828-833, 2012.

[21] IBGE. Banco de Dados Agregados. Disponível em: http://www.sidra.ibge.gov.br . Acesso em 30 de março 2021.

[22] IBGE. Manual técnico da vegetação brasileira. Rio de Janeiro, 1992. 92 p.

[23] IBGE. Zoneamento geoambiental e agroecológico do estado de Goiás: região noroeste. IBGE/Divisão de Geociências do Centro-Oeste, Rio de Janeiro, RJ, 1995.

[24] KAGEYAMA, P.; GANDARA, F. Restauração e conservação de ecossistemas tropicais. In: CULLEN JR., L; VALLADARES-PÁDUA, C.; RUDRAN, R. (orgs.). Métodos de Estudos em Biologia da Conservação e Manejo da Vida Silvestre. Curitiba: UFPR, Fundação O Boticário de Proteção à Natureza, 2003. p. 383-394.

[25] KILCA, R.V.; LONGHI, S. J. A composição florística e a estrutura das florestas secundárias no rebordo do Planalto Meridional. In: SCHUMACHER, M.V.; LONGHI, S. J.; BRUN, E.J.; KILCA, R.V. (Eds.). A Floresta Estacional Subtropical: caracterização e ecologia no rebordo do Planalto Meridional. Santa Maria: Pallotti, cap. 4, p. 53-83, 2011.

[26] LEITE, P. F; KLEIN, R. M. Vegetação. In: IBGE. Geografia do Brasil: Região Sul. Rio de Janeiro, 1990. p. 115150

[27] LEITÃO FILHO, H. F.; PAGANO, S. N.; CESAR, O.; TIMONI, J. L.; RUEDA, J. J Ecologia da Mata Atlântica em Cubatão (SP). São Paulo: Editora da UNEESP; Campinas: Editora UNICAMP, 1993.

[28] LONGHI, S. J.; NASCIMENTO, A. R. T.; FLEIG, F. D.; DELlA-FlORA, J.B.; FREITAS, R. A.; CHARÃO, L. S. Composição florística e estrutura da comunidade arbórea de um fragmento florestal no município de Santa Maria, Brasil. Ciência Florestal, Santa Maria, v. 9, n. 1, p. 115-133, 1999.

[29] MAGNAGO, L. F. S.; MARTINS, S. V.; VENKKE, T. S.; IVANAUSKAS, N. M. Os processos e estágios sucessionais da mata atlântica como referência para a restauração florestal. In: MMARTINS, S.V. (Ed): Restauração ecológica de ecossistemas degradados, Viçosa, MG: Ed. UFV, p.69-100, 2012.

[30] MANTELLI, J. A organização cultural do espaço agrário no Noroeste do Rio Grande do Sul. In: XIX Encontro Nacional de Geografia Agrária, 2009, São Paulo. Anais: São Paulo XIX ENGA, 2009. Disponível em: http://repositorio.furg.br/bitstream/handle/1/1108/A\%200RGANIZA\%C3\%87\%C3\%830\%20DE\%20UM\%20ESPA \%C3\%870\%20INTER-\%C3\%89TNICO.pdf?sequence=1. Acesso em 30 março 2021.

[31] MANTELLI, J. A. O processo de ocupação do Noroeste do Rio Grande do Sul e a evolução agrária. Revista Geografia, Rio Claro-São Paulo, v.31, n.2, p.269-278, mai-ago, 2006.

[32] MARTINS, S. V.; RODRIGUES, R. R.; GANDOLFI, S. CALEGARI, L. Sucessão ecológica: Fundamentos e aplicações na restauração de ecossistemas florestais. In: MARTINS, S. V.; Ecologia de florestas tropicais do Brasil. Viçosa, UFV, 2012, 371p.

[33] MARTINS, S. V. Recuperação de matas ciliares. Viçosa, MG: Editora Centro de Produções Técnicas, 2007. $255 \mathrm{p}$. 
[34] MARTINS, S. V.; BUSATO, L. C.; CALEGARI, L. RIBEIRO, T. M. A contribuição da ecologia florestal no desenvolvimento de modelos e técnicas de restauração florestal de áreas degradadas. Revista Ação Ambiental, v. 10, n. 36 , p. 10-13, 2007.

[35] MARTINS, S. V. et al. Potencial de regeneração natural de florestas nativas nas diferentes regiões do estado do Espírito Santo. CEDAGRO- Centro de desenvolvimento do agronegócio. Vitória, 2014. Disponível em: < http://www.larf.ufv.br/wp-content/uploads/ES-_ESTUDO_REGENERACAO_NATURAL_-_Completo_abr14.pdf >. Acesso em: 28 março 2021.

[36] METZGER, J. P.; LEWInSOHN, T. M.; JOLY, C. A.; VERDADE, L. M.; MARTINELLI, L. A.; RODRIGUES, R. R. Brazilian Law: Full Speed in Reverse? Science. v. 329, n. 5989, p. 276-277, 2010.

[37] MEYER, E. A. Estrutura do estrato regenerante e impacto do corte seletivo de árvores sobre a regeneração natural em uma Floresta Estacional Decidual. 2008, 38 p. Trabalho de Conclusão de Curso (Graduação em Engenharia Florestal) - Universidade Federal de Santa Maria, Santa Maria, RS, 2008.

[38] RODRIGUES, R.R.; GANDOLFI, S. Conceitos, tendências e ações para recuperação de florestas ciliares. In: RODRIGUES, R. R.; LEITÃO-FILHO, H. F. (Eds.). Matas ciliares: conservação e recuperação. 2 ed. São Paulo: EDUSP, 2009, p. 235-247.

[39] RODRIGUES, R. R.; LIMA, R. A. F.; GANDOLFI, S. NAVE, A. G. On the restoration of high diversity forests: 30 years of experience in the Brazilian Atlantic Forest. Biological Conservation, Oxford, v. 142, n.6, p.1242-1251, 2009.

[40] RORATO, D. G. et al. Silvicultura com espécies florestais nativas mediante o plantio de mudas: uma experiência em áreas ripárias no Sul do Brasil. In: Produção de sementes e mudas um enfoque à Silvicultura. Editora UFSM, Santa Maria, p. 367-382, 2018.

[41] ROSA, P. A.; BREUNING, F. M; ALMEIDA, M. de; BALBINOT, R. Dinâmica de Fragmentos Florestais no Noroeste do Rio Grande do Sul. Geografia, Ensino \& Pesquisa, Santa Maria, v.21, n.1, p.177-189. 2017. Disponível em: < https://periodicos.ufsm.br/geografia/article/view/24059/pdf>. Acesso em: 01 março de 2021.

[42] SARTORELLI, P. A. R.; CAMPOS FILHO, E. M. Guia de plantas da regeneração natural do Cerrado e da Mata Atlântica. São Paulo, Agroicone, 2017, 140 p.

[43] SECRETARIA ESTADUAL DO MEIO AMBIENTE - SEMA. Plano de manejo do Parque Estadual do Turvo. Porto Alegre: SEMA, 2005. 348 p.

[44] SCHUMACHER, M. V. et al. A Floresta Estacional Subtropical: caracterização e ecologia no rebordo do Planalto Meridional. Santa Maria: Pallotti, 2011.320p.

[45] SERVIÇO FLORESTAL BRASILEIRO - SFB. Inventário Florestal Nacional: principais resultados: Rio Grande do Sul. Serviço Florestal Brasileiro. Brasília, DF: MMA, 2018.

[46] TURCHETTO, F. et al. Can transplantation of forest seedlings be a strategy to enrich seedling production in plant nurseries? Forest Ecology and Management, Amsterdam, v. 375, p. 96-104, 2016.

[47] TURCHETTO, F. et al. Intensive silvicultural practices drive the forest restoration in southern

[48] Brazil. Forest Ecology and Management, Amsterdam, v. 473, 2020. 


\section{Capítulo 4}

Compostagem doméstica: Uma prática adequada de transformação, diminuição e disposição alternativa dos resíduos orgânicos gerados em ambientes domiciliares

\section{Francisco Edirlan de Sousa Freitas \\ Everlene de Sousa Freitas \\ Laís Regina Gomes de Oliveira Freitas}

Resumo: 0 crescimento populacional no Brasil, entre outras consequências, tem acarretado o aumento de forma substancial e significativa na produção de resíduos sólidos no país, não sendo diferente nos ambientes familiares. Diante disso, buscou-se através desse trabalho, analisar e avaliar meios alternativos para a disposição final dos resíduos orgânicos domiciliares. A metodologia desenvolvida tem caráter qualitativo, apresentando uma abordagem analítica e exploratória. Depois de uma série de atividades elaborada como a problematização da temática, pesquisas e levantamento bibliográfico para a melhor adequação da realidade, elaboração do projeto, implementação, monitoramento e obtenção e aplicação do produto final, buscou-se através de técnica compostagem, um tratamento e transformação dos resíduos orgânicos obtendo-se um produto final com inúmeros benefícios de características físicas, químicas e biológicas que agrega valor nutritivo ao solo, além de contribuir para a criação de meios alternativos de disposição final, como também a minimização de resíduos enviados aos lixões e/ou aterros sanitários.

Palavras-Chave: Compostagem, resíduos orgânicos, domiciliares, adubo 


\section{INTRODUÇÃO}

A produção de lixo no Brasil cresce rapidamente em ritmo mais acelerado do que a população urbana. É o que mostra o Panorama dos Resíduos Sólidos no Brasil (2011), estudo feito pela Associação Brasileira de Empresas de Limpeza Pública e Resíduos Especiais (Abrelpe). Pelo levantamento, os brasileiros geraram em 2011 cerca de 60,9 milhões de toneladas de resíduos sólidos urbanos, crescimento de 6,8\% sobre 2010. No mesmo período segundo o Instituto Brasileiro de Geografia e Estatística (IBGE), a população cresceu em torno de $1 \%$.

Diante dessa problemática, encontrar alternativas tecnicamente e economicamente viáveis tornou-se um escape para a minimização dos resíduos orgânicos gerados em ambientes urbanos. Visto que a prática da compostagem contribui de forma substancial para a não poluição do meio ambiente, pois cidades ainda não possuem formas adequadas para a disposição final dos resíduos gerados, comprometendo a qualidade do solo, do ar e dos mananciais.

A técnica de compostagem é uma excelente forma de processamento e transformação dos resíduos orgânicos produzidos em ambientes domiciliares. A compostagem é um processo que pode transformar diversos tipos de resíduos orgânicos em adubo que, quando adicionado ao solo agrega características de beneficiamento do mesmo, sejam elas físicas, físico-químicas ou biológicas. 0 composto obtido (adubo) é formado por matéria orgânica (Mo) humidificada, resto de alimentos, cascas de frutas e legumes, bagaços de frutas, borra de café, entre outros compõe o produto a mistura essencial para obtenção do produto final da compostagem.

Estes materiais são a principal fonte de composição para o processo de compostagem comum, e possuem uma relação de carbono/nitrogênio (C/N) média adequada para o processo (BELEM, 2004). No final do processo pode-se usar o composto orgânico como adubo, seja ele direcionado a nutrir plantas de jardins ou hortaliças de fácil plantio e manejo.

O mapeamento das residências e comunidades que possam receber o projeto de compostagem doméstica é de fundamental importância, oferecendo o pesquisador toda a orientação e assistência necessária a execução do projeto, bem como seu objetivo e benefícios.

Os lixões ainda são uma realidade em diversas regiões do Brasil, mesmo depois da lei no 12.305/2010 sancionada em 2010 - Política Nacional de Resíduos Sólidos - (PNRS), ainda o seu cumprimento caminha de forma discreta, não atendendo em sua totalidade o que é exigido. Complementando sua ação positiva, alinha-se a uma técnica de fácil acesso e manipulação, viável economicamente e de entendimento acessível, que favoreça a realização e contribuição para um ambiente ecologicamente equilibrado.

De acordo com o Instituto Brasileiro de Geografia e Estatística (IBGE), o Brasil descarta a cada dia 230.000 toneladas de detritos e mais da metade disso corresponde ao lixo doméstico descartado pela população brasileira (IBGE, 2009). Do total produzido nas residências, apenas $2 \%$ do total é destinado à coleta seletiva (ELEM AQUINO, 2009). 0 restante vai para lixões a céu aberto ou na melhor das hipóteses, em aterros sanitários onde muitas vezes sua capacidade máxima já está próxima do limite. 0 desempenho das administrações municipais deixa a desejar entre muitos aspectos, porém é mais alarmante quando se trata dos problemáticos gerenciamentos dos resíduos gerados. Muitos municípios se querem possuem aterros sanitários adequado para a disposição dos resíduos gerados em suas cidades agravando ainda mais a situação.

A lei no 12.305/10, que institui a Política Nacional de Resíduos Sólidos (PNRS) é bastante atual e contém instrumentos importantes para permitir o avanço necessários ao País, no enfrentamento dos principais problemas ambientais, sociais e econômicos decorrentes do manejo inadequado dos resíduos sólidos. Prevê a prevenção e a redução na geração de resíduos, tendo como proposta a prática de hábitos de consumo sustentável e um conjunto de instrumentos para propiciar o aumento da reciclagem e da reutilização dos resíduos sólidos (aquilo que tem valor econômico e pode ser reciclado ou reaproveitado) e a destinação ambientalmente adequada dos rejeitos (aquilo que não pode ser reciclado ou reutilizado).

0 presente trabalho tem como objetivo analisar e avaliar meios alternativos para a disposição final de resíduos orgânicos evitando o envio do lixo orgânico doméstico para os aterros sanitários e/ou lixões a céu aberto, buscando meio de disposição, viável financeiramente e tecnicamente, causando um menor impacto ambiental e dando através da compostagem um novo destino ecologicamente correto do lixo domiciliar, aplicando boas práticas por meio da conscientização ambiental. 0 método adotado para a realização do presente trabalho tem caráter qualitativo, apresentando uma abordagem analítica e exploratória. 
A pesquisa qualitativa não se preocupa com representatividade numérica, mas, sim, com o aprofundamento da compreensão de um grupo social, de uma organização, etc. Os pesquisadores que adotam a abordagem qualitativa opõem-se ao pressuposto que defende um modelo único de pesquisa para todas as ciências, já que as ciências sociais têm sua especificidade, o que pressupõe uma metodologia própria. Assim, os pesquisadores qualitativos recusam o modelo positivista aplicado ao estudo da vida social, uma vez que o pesquisador não pode fazer julgamentos nem permitir que seus preconceitos e crenças contaminem a pesquisa (GOLDENBERG, 1997, p. 34)

Visando a conscientização de preservar e contribuir positivamente para um meio ambiente ecologicamente equilibrado, a temática compostagem em ambientes domésticos traz ao cidadão uma forma de transforma-lo em indivíduos que se comportam como agentes modificadores do meio onde vivem e convivem. De ante da afirmação acima indaga-se: Como trabalhar de forma sustentável com a problemática do lixo? Quais são os meios alternativos disponíveis para a diminuição dos resíduos orgânicos gerados em ambientes domiciliares?

\section{OBJETIVO}

Analisar e avaliar meios alternativos para a disposição final de resíduos orgânicos, propondo meios alternativos para os resíduos orgânicos gerados em ambientes domésticos, realizando análise financeira e técnica, através da compostagem, como um novo destino ecologicamente correto do lixo orgânico domiciliar, aplicando boas práticas por meio da conscientização e conhecimento do meio ambiente.

\section{METODOLOGIA}

A metodologia adotada para a realização e execução do trabalho tem caráter qualitativo, visto que busca entender o ambiente natural como fonte direta de dados e o pesquisador como instrumento fundamental, adota um caráter descritivo e analítico e exploratório e tenta alcançar o significado que as pessoas dão as transformações e à sua vida como preocupação do investigador.

Tem por objetivo traduzir e expressar o sentido dos fenômenos do mundo social, trata-se de reduzir a distância entre indicador e indicado, entre a teoria e dados, entre contexto e ação (MAANEN, 1979a, p.520)*.

No primeiro momento, depois da problematização e todas as possíveis análises que precedem e procedem aa etapa antes da escolha da metodologia, buscou-se uma pesquisa documental, na qual constituída pelo exame de materiais que não receberam nenhum tratamento analítico, revisão bibliográfica, pesquisa sobre a técnica de compostagem em livros, artigos, e outros meios de informações.

A escolha da residência que irá contribuir para a implementação do projeto é de fundamental importância, visto que ela irá contribuir de forma significativa para o implementação e desenvolvimento da pesquisa, agindo de forma ativa na realização das diversas parte do processo.

Para este trabalho foi utilizada uma composteira plástica vertical perfurada. A composteira foi confeccionada da seguinte forma: Adquiriu-se um recipiente plástico com tampa de capacidade aproximadamente de 20L. Fez-se vários orifícios ao longo de sua estrutura, parte lateral, superior e inferior, com o objetivo de se ter uma melhor aeração do resíduo. Colocou-se em lugar apropriado para iniciar e dá continuidade ao processo.

Colocou-se os resíduos orgânicos gerados no domicilio, formado basicamente de cascas e restos de frutas, verduras, legumes e borra de café.

O monitoramento e avaliação da assimilação da ideia da pesquisa, através de questionamentos periódicos, seja por meio de questionário impresso ou virtual e visitas periódicas a residência escolhida por parte do pesquisador irá constatar o bom andamento ou não da pesquisa. 


\section{RESULTADOS}

\section{ETAPA 1: PROBLEMATIZAÇÃO DO TEMA}

As sobras de comida estão presentes em todos os ambientes domésticos, sejam elas restos de frutas e verduras, porra de café, entre outros que compõem o lixo orgânico doméstico. Muitas vezes a sobra de preparo de alguma alimentação pode ser guardada para reuso, porém existem outras que são descartadas de imediato, por existir a possibilidade de causar alguma infecção alimentar, necessitando de realizar o descarte diário desses alimentos. Esse resíduo pode perfeitamente se enquadrar no perfil de matériaprima para a compostagem.

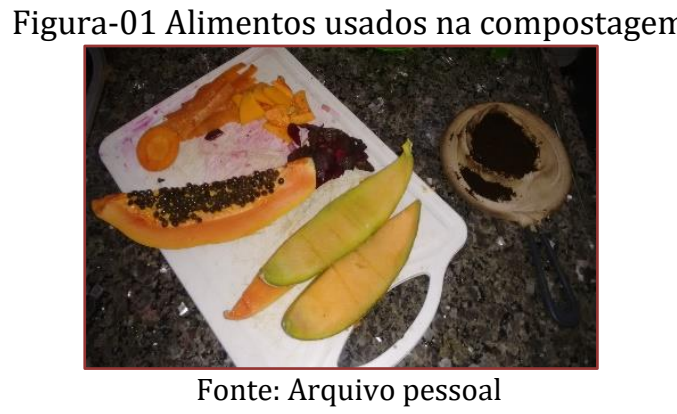

\section{ETAPA 2: ELABORAÇÃO DO PROJETO DE COMPOSTAGEM E ESCOLHA DA RESIDÊNCIA}

A escolha do domicilio que daria o apoio para implementação do projeto e execução das atividades, foi de fundamental importância. A partir dele, todas as informações que seriam geradas eram essenciais para o bom desenvolvimento e andamento da pesquisa, assim como comprometimento dos evolvidos. As coletas dos dados, foram feitas de forma verbal, anotadas, analisadas e comparadas com a literatura, afim de posteriormente serem discutidas.

\section{ETAPA 3: IMPLEMENTAÇÃO DA COMPOSTAGEM}

Para implementação da composteira domestica faz-se necessário confecciona-la, o material pode ser adquirido em qualquer centro comercial do seguimento de plásticos, ou pode também ser confeccionar a partir de recipientes, como baldes ou embalagens plásticas de usos diversos. 0 recipiente deve ser perfurado na lateral e partes superiores e inferiores, os orifícios em toda a sua extensão podem ser perfurados com furadeira elétrica, para que assim seja facilidade a aeração da composteiras. Para acontecer o processo aeróbio, o meio deve ser aerado para que os microrganismos presentes possam realizar reações que necessitam de $\mathrm{O}_{2} . \mathrm{O}$ ar a ser utilizado pode ser o ar atmosférico, e, em muitos casos, esta aeração é feita ao remexer a pilha de compostagem. As temperaturas neste processo são elevadas (maior que $55^{\circ} \mathrm{C}$ ) pois ocorre liberação de gases $\left(\mathrm{CO}, \mathrm{CO}_{2}\right.$ e vapor de água) no meio através de reações exotérmicas. Existem outras maneiras de aeração, algumas mais sofisticadas, com o auxilio de máquinas, e outras mais criativas, como o uso de um túnel de ventilação, para a produção de uma leira estática. (BELEM, 2004).

Figura-02 Composteira confeccionada (sem tampa

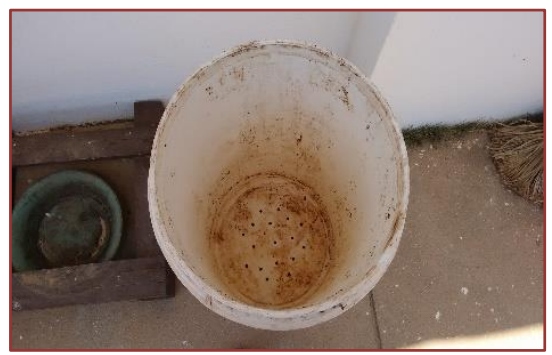

Fonte: Arquivo pessoal
Figura-03 Composteira confeccionada (com

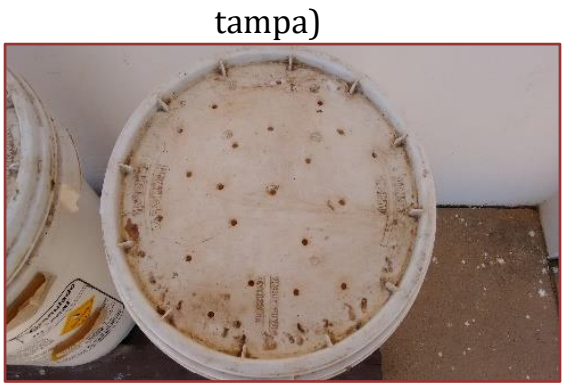

Fonte: Arquivo pessoal 


\section{ETAPA 4: MONITORAMENTO DA COMPOSTEIRA E ASSIMILAÇÃO DA IDEIA}

A matéria orgânica que irá para a composteira deve ter o tamanho ótimo para as partículas com valores entre 2,5 e 5,0 cm, sendo bom ter partículas de todos os tamanhos entre este intervalo, para que o ar possa transitar mais facilmente entre as pilhas, e a velocidade de decomposição de cada composto viável para o processo (MARTIN, 1991). Um dos processos de diminuição do tamanho de partícula é o de trituração do composto antes de ser implantado nas composteiras. Para diminuir o tamanho dessas particulas, podem ser utilizados moinhos de diversos tipos, sendo os mais utilizados os motinhos de martelo, devido a sua capacidade de trabalho e seu rendimento serem elevados (LIMA, 2004).

Na fase de degradação da matéria orgânica o aquecimento da massa apresenta predominantemente temperaturas moderadas, até cerca de $40{ }^{\circ} \mathrm{C}$. Tem duração média de dois a cinco dias. $\mathrm{O}$ instrumento ideal para medir a temperatura da leira de compostagem usualmente é o termômetro, porém pode-se também verificar a temperatura de forma empírica, com o uso de uma barra de ferro, inserida por algum tempo até que a barra entre em equilíbrio térmico com a leira, então o indivíduo verifica se a temperatura está aumentando ou não.

Maus odores também podem aparecer durante a compostagem, as possíveis causas podem ser o tamanho das partículas, a medida a ser tomada é quebrar o material durante o reviramento com o auxílio de um material cortante. 0 surgimento de maus odores também pode ocasionar a atração de moscas e mosquitos na massa de compostagem, a medida a ser tomada é a mesma também já citada.

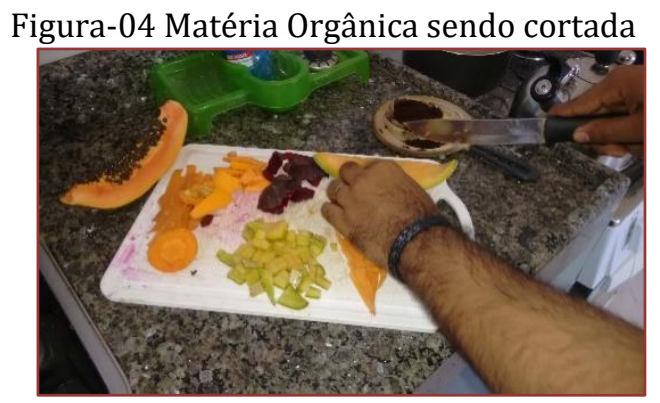

Fonte: Arquivo pessoal

\section{ETAPA 5: OBTENÇÃO E APLICAÇÃO DO PRODUTO FINAL}

Após todo o processo de compostagem ter chegado ao fim, ou seja, todo o material orgânico ter sido humificado, o composto produzido tende a apresentar características constantes e homogêneas, como relação C/N em torno de 10/1 (MARTIN, 1991).

Este composto orgânico produzido através de resíduos, pode melhorar propriedades físicas, químicas ou biológicas do solo, podendo então ser classificado como um adubo orgânico, apesar de não poder substituir integralmente os fertilizantes químicos, como o N.P.K. (LIMA, 2004) Porém, M. S. Pinto (1979) verificou que a aplicação do composto orgânico produzido por este método produz resultados satisfatórios, quando utilizado sozinho para adubação, como: Retenção da umidade do solo em períodos de seca, prevenção contra erosão, fornecimento de alguns nutrientes principais, prevenção da lixiviação do nitrogênio orgânico, entre outros.

Figura-05 Produto final da compostagem peneirado

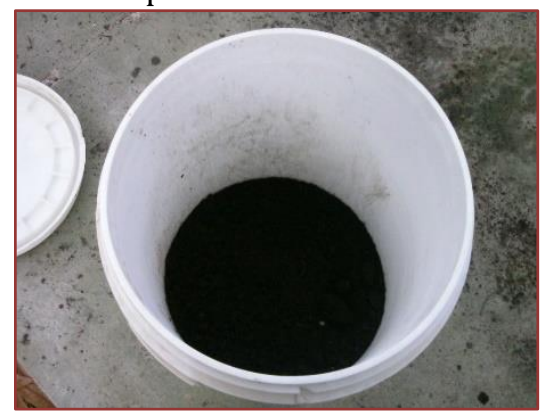

Fonte: Arquivo pessoal
Figura-06. Aplicação do produto final

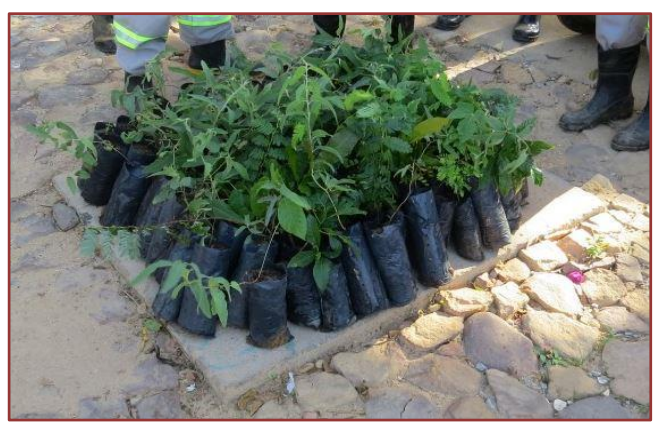

Fonte: Arquivo pessoal 


\section{CONCLUSÕES}

Com a problemática do lixo na atualidade, que envolve inúmeros fatores, como por exemplo, crescimento urbano desordenado, aumento significativo da produção de resíduos, a disposição final inadequada entre outros, acrescido de cidades do Brasil que ainda são deficitárias em relação a coleta, transporte e disposição final dos resíduos gerados, encontrar alternativas viáveis que contribuam de forma positiva para a diminuição dos impactos ambientais provenientes do lixo urbano, traz a sociedade inúmeros benefícios socioambientais, despertando nos cidadãos um interesse de como contribuir de forma positiva para a preservação do meio ambiente onde vive, através de medidas simples e de fácil manuseio.

A compostagem traz todos esses benefícios além de ter como produto final um material que pode ser agregado ao solo, ocasionando inúmero benefícios de características físicas, químicas e biológicas.

\section{REFERÊNCIAS}

[1] BELÉM, P. A. Processo de compostagem, a partir de lixo orgânico urbano, em leira estática com ventilação natural, 2004.

[2] BRASIL. Lei 12.305 de 02 de agosto de 2010 - Política Nacional de Resíduos Sólidos. Biblioteca Digital da Câmara dos Deputados. 2010.Disponível em: http://www.saude.rs.gov.br/upload/1346166430_Lei\%2012.305_02082010_politica_residuos_solidos.pdf.

[3] GOMES, E.T; Piesanti, J.E; Vilela, D.M. Compostagem em Comunidades Indígenas. 8o Encontro de Pesquisa e Extensão - FCA/UFGD.

[4] http://planetasustentavel.abril.com.br/noticia/lixo/lixo-domestico-coleta-seletiva-separacao-dicas501359.shtml

[5] INACIO, C.T, MILLER, P.R.M. Compostagem: Ciência e prática para a gestão de resíduos orgânicos, Rio de Janeiro, Embrapa Solos, 2009.

[6] INMETRO - Instituto Nacional de Metrologia, Qualidade e Tecnologia. Direitos do consumidor: ética no consumo. Rio de Janeiro: Idec, 2002.

[7] MAANEN, John, Van. Reclaiming qualitative methods for organizational research: a preface. In administrative Science Quarterly. Vol 24, no 4, December 1979 a, pp 520-526

[8] KIEHL, E. J. Metodologia da compostagem e ação fertilizante do composto de resíduos domiciliares. Escola Superior de Agricultura Luiz Queiroz, Universidade de São Paulo, Piracicaba, 1979. 


\section{Capítulo 5}

Efluentes domésticos e seus impactos no meio ambiente no bairro do Alegre em Bragança - PA

\section{Odilon Augusto Rêgo de Lima \\ Luciana Leal Pimentel Oliveira}

Resumo: Os efluentes domésticos, de acordo com Tucci (2005) são dejetos originados oriundos de ambientes domésticos e são constituídos basicamente por contaminantes orgânicos, nutrientes e microrganismos, que podem ser patogênicos. Ou seja, materiais originados pelo descarte das residências, constituído de sobras de alimentos, produtos estragados, revistas, jornais, garrafas, embalagens em geral, fraldas, papéis e uma grande diversidade de produtos tóxicos. 0 presente trabalho tem como objetivo avaliar os efluentes domésticos no bairro do Alegre, localizado no município de Bragança - PA, considerando os prejuízos ambientais gerados tanto pela sua quantidade quanto pela sua toxidade. 0 levantamento bibliográfico foi realizado através do tripé existente entre saneamento básico, meio ambiente e saúde pública, onde foi estudado o serviço de abastecimento de água, esgoto e resíduos sólidos. Tendo como indicador de impactos no ecossistema o uso de uma avaliação rápida, ao qual essa avaliação constitui a observação do ambiente e caracterização local, utilizando métodos pré-definidos pelo protocolo de Callisto (CALLISTO; MORENO, 2006). A partir da metodologia empregada, notou-se os impactos provocados pela disposição inapropriada do lixo, em que uma das medidas para atenuar o problema é a existência de uma conscientização ambiental, em que o saneamento básico deve ser incorporado a um modelo de desenvolvimento que atenda as questões sociais, executando ações de forma racional e participativa, exercendo um gerenciamento conveniente dos resíduos, acarretando saúde, bem-estar e melhoria na qualidade de vida..

Palavras-chave: Efluentes Domésticos, Impacto Ambiental, Resíduos Sólidos, Saneamento. 


\section{INTRODUÇÃO}

A carência de saneamento básico é apontada como um dos principais fatores responsáveis relacionados aos problemas de saúde pública. A falta de interesse dos poderes públicos para manter uma fiscalização e as ações antrópicas sobre os recursos hídricos tais como, construção de barragens, reservatórios e canalização dos cursos d'agua e o despejo inadequado dos efluentes, acarretam em diversos problemas, onde se faz necessário avaliar e acompanhar as possíveis alterações ambientais e suas consequências (RODRIGUES et al., 2008).

De acordo com a NBR 9648 (ABNT, 1986), esgoto sanitário é o despejo líquido constituído de esgotos doméstico e industrial, água de infiltração e a contribuição pluvial parasitária. Ainda segundo a mesma norma, o esgoto doméstico é o despejo líquido proveniente principalmente de residências, edifícios comerciais, instituições ou quaisquer edificações que contenham instalações de banheiros, lavanderias, cozinhas ou qualquer dispositivo de utilização da água para fins domésticos. Compõem-se essencialmente da água de banho, urina, fezes, papel, restos de comida, sabão, detergentes, águas de lavagem (JORDÃO, 2009).

Descarte inapropriado dos efluentes domésticos facilita a proliferação de insetos e o desenvolvimento de inúmeros vetores, tanto de invertebrados a mamíferos roedores. Sistemas adequados de tratamento, como Estação de Tratamento de esgoto são essenciais, visando à melhoria da população, ou seja, combatendo diretamente o dano à saúde humana e ambiental.

Para monitoramento e garantia da conservação do corpo receptor é necessário o atendimento à Resolução CONAMA N 357, de março de 2005 (MMA, 2006), em que o efluente deve ser encaminhado para ETEs, onde receberá tratamento antes do lançamento em corpos d'água ou infiltração no solo, para evitar a contaminação ambiental e possíveis riscos à saúde pública. Todavia, junto a todo esse manejo, deve-se vir uma educação ambiental e a execução de projetos sustentáveis, para que os habitantes tenham consciência dos próprios atos atenuando os problemas existentes.

\section{OBJETIVO}

Portanto, este trabalho a partir da pesquisa que fora desenvolvida, procura colaborar em uma conscientização ambiental e compreensão legislativa a fim de amenizar a problemática causada pelo descarte inapropriado do esgoto sanitário, originada pela falta de iniciativa do governo e instrução dos moradores do bairro do Alegre na cidade de Bragança, com o objetivo, de proporcionar uma melhor qualidade de vida aos moradores.

\section{METODOLOGIA}

0 trabalho foi realizado em um dos afluentes do Rio Cereja na cidade de Bragança (Figura 1). 0 município se localiza na mesorregião amazônica, possuindo uma área de $2.090 .234 \mathrm{~km}^{2}$ e população de aproximadamente 122.881 habitantes (IBGE 2016). 0 município é formado por 13 bairros e por algumas invasões na zona de periferia da cidade e adjunto a um processo de degradação do meio ambiente. 


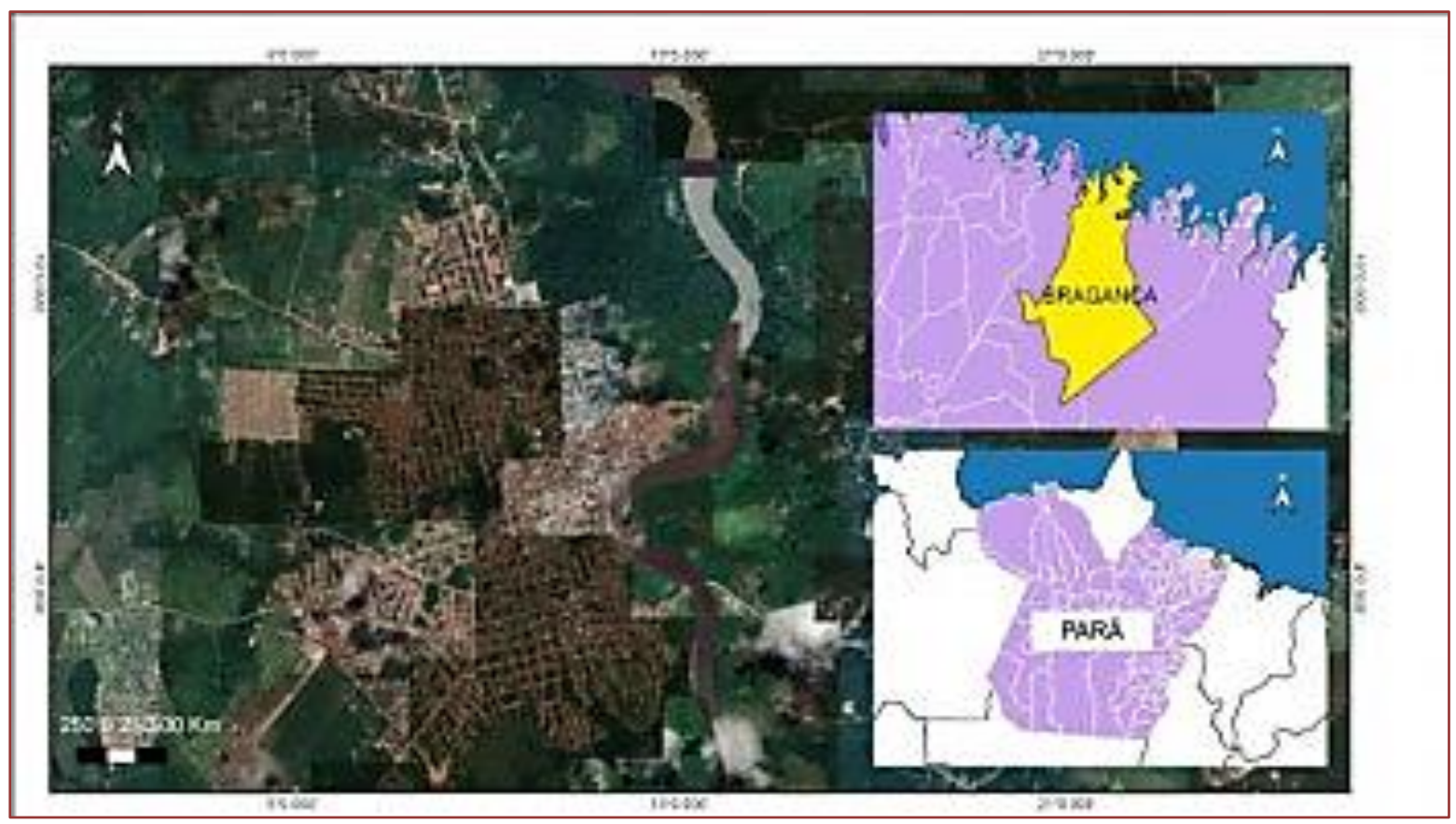

Fonte: Autor do Trabalho.

A bacia hidrográfica local é composta por 2 rios, sendo o principal o Rio Caeté e o Rio Cereja, rio esse que corta a cidade de Bragança e rio alvo da pesquisa. Possuindo uma vegetação de Terra Firme e composto pela área de manguezal. 0 clima é úmido tropical, tendo como período chuvoso o primeiro semestre do ano, apresentando um índice de pluviosidade anual de aproximadamente $2501 \mathrm{~mm}$. (OLIVEIRA e WOLLMANN, 2016).

O trabalho aplicou o método de pesquisa bibliográfica, seguindo o conceitual de Jordão (2009), em que ressalta que o efluente deverá ser encaminhado para estações de tratamento de esgoto (ETEs), onde receberá tratamento adequado. Realizamos: pesquisa bibliográfica, visando coletar dados através de livros e publicações avulsas; pesquisa explicativa, onde visamos explicar os motivos em que o esgoto se encontra na determinada situação; pesquisa experimental, dessa forma estaremos analisando a qualidade da água que se encontra e a pesquisa de campo, já que entraremos em contato direto com o espaço e as pessoas efetuando através de entrevistas informais, questionários abertos. Analisando detalhadamente o bairro do Alegre da cidade de Bragança no estado do Pará e os dados obtidos de diversas maneiras.

0 trabalho utilizou uma fita métrica de $5 \mathrm{~m}$, câmera fotográfica e o protocolo de Callisto para uma análise do córrego. Esse protocolo é uma forma de avaliação rápida, elaborada por Callisto et al. (2002), onde se baseia numa avaliação visual do ambiente e numa tabela conceituada por características e pontuação se estabelece uma média e assim uma nota para aquele corpo hídrico e o que o cerca.

\section{RESULTADOS}

O levantamento de dados e imagens fotográficas foi realizado no bairro do Alegre, procurando evidencias de impactos como apresentado nas Figuras 2, 3 e 4, para uma futura solução adequada do problema em questão. 
Figura 2: Despejo dos Efluentes

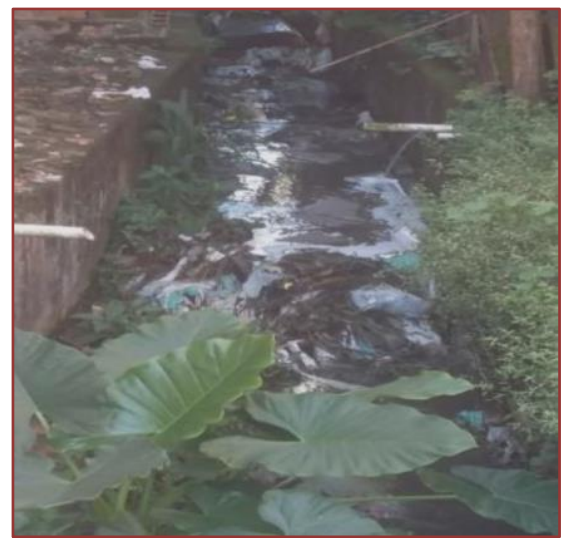

Fonte: Autor do Trabalho

Figura 3: Assoreamento do córrego

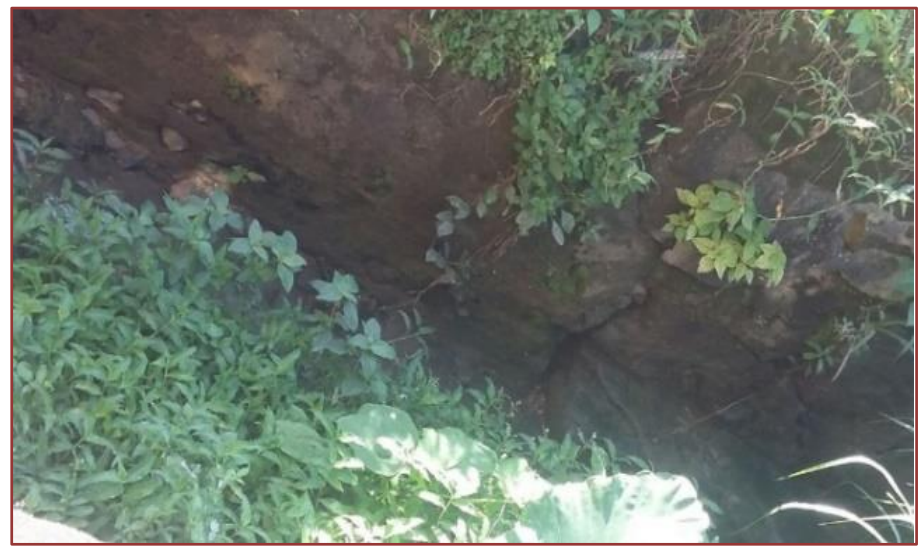

Fonte: Autor do Trabalho

A partir dos dados coletados foi possível averiguar após o uso da metodologia que tal efluente é manuseado de forma incorreta é muito impactado. Tendo abaixo os resultados coletados da aplicação partindo do conceitual da pontuação:

- 4 pontos - situação natural;

- 2 pontos - situação leve;

- 0 pontos - severamente alteradas.

Neste primeiro quadro observou-se: 
Tabela 1 Protocolo de Avaliação Rápida da Diversidade de Habitats em trechos de bacias hidrográficas.

\begin{tabular}{|c|c|c|c|}
\hline \multicolumn{4}{|c|}{ Descrição do Ambiente } \\
\hline \multicolumn{4}{|c|}{ Localização: Travessa Costa Rodrigues, Bairro: Alegre - Bragança - PA. } \\
\hline \multicolumn{2}{|c|}{ Data de Coleta: 06/02/2020 } & \multicolumn{2}{|c|}{ Hora da Coleta: $09 \mathrm{~h} 20 \mathrm{minh}$} \\
\hline \multicolumn{4}{|c|}{ Tempo (situação do dia): Ensolarado } \\
\hline \multicolumn{4}{|c|}{ Tipo de Ambiente: Córrego $(\mathrm{X}) \quad$ Rio ( ) } \\
\hline \multicolumn{4}{|l|}{ Largura média: 3 metros } \\
\hline \multicolumn{4}{|l|}{ Profundidade média: 1,5 metros } \\
\hline \multirow{2}{*}{ PARÂMETROS } & \multicolumn{3}{|c|}{ PONTUAÇÃO } \\
\hline & 4 pontos & 2 pontos & 0 ponto \\
\hline $\begin{array}{l}\text { 1. Tipo de ocupação } \\
\text { das margens do corpo d'água } \\
\text { (principal atividade) }\end{array}$ & Vegetação natural & $\begin{array}{l}\text { Campo de } \\
\text { pastagem/Agricultura } \\
\text { /Monocultura/ } \\
\text { Reflorestamento }\end{array}$ & $\begin{array}{l}\text { Residencial/ comercial/ } \\
\text { Industrial }\end{array}$ \\
\hline $\begin{array}{l}\text { 2. Erosão próxima e/ou nas } \\
\text { margens do rio e assoreamento } \\
\text { em seu leito }\end{array}$ & Ausente & Moderada & Acentuada \\
\hline 3. Alterações antrópicas & Ausente & $\begin{array}{l}\text { Alterações de } \\
\text { origem doméstica } \\
\text { (esgoto, lixo) }\end{array}$ & $\begin{array}{l}\text { Alterações de origem industrial/ urbana } \\
\text { (fábricas, siderurgias, canalização, } \\
\text { retilinização do curso do rio). }\end{array}$ \\
\hline 4. Cobertura vegetal no leito & Parcial & Total & Ausente \\
\hline 5. Odor da água & Nenhum & Esgoto & óleo/industrial \\
\hline 6. Oleosidade da água & Ausente & Moderada & Abundante \\
\hline 7. Transparência da água & Transparente & $\begin{array}{l}\text { Turva (cor de chá- } \\
\text { forte) }\end{array}$ & opaca ou colorida \\
\hline $\begin{array}{l}\text { 8. Odor do sedimento } \\
\text { (fundo) }\end{array}$ & Nenhum & Esgoto & óleo/industrial \\
\hline 9. Oleosidade do fundo & Ausente & Moderado & Abundante \\
\hline 10. Tipo de fundo & Pedra/cascalho & Lama/areia & cimento/canalizado \\
\hline
\end{tabular}

Fonte: Autor do Trabalho 
Tabela 2: Protocolo de Avaliação Rápida da Diversidade de Habitats em trechos de bacias hidrográficas. (Obs.: 5 pontos (situação natural), 3, 2 e 0 pontos (situações leve ou severamente alteradas)

\begin{tabular}{|c|c|c|c|c|}
\hline \multirow[t]{2}{*}{ PARÂMETROS } & \multicolumn{3}{|c|}{ PONTUAÇÃO } & \multirow[b]{2}{*}{0 ponto } \\
\hline & 5 pontos & 3 pontos & 2 pontos & \\
\hline 11. Tipos de fundo & $\begin{array}{l}\text { Mais de } 50 \% \text { com } \\
\text { habitats } \\
\text { diversificados; } \\
\text { pedaços de troncos } \\
\text { submersos; cascalho } \\
\text { ou outros habitats } \\
\text { estáveis. }\end{array}$ & $\begin{array}{l}30 \text { a } 50 \% \text { de } \\
\text { habitats } \\
\text { Diversificados; } \\
\text { habitats } \\
\text { Adequados para a } \\
\text { manutenção das } \\
\text { populações de } \\
\text { organismos } \\
\text { aquáticos. }\end{array}$ & $\begin{array}{l}10 \text { a } 30 \% \text { de habitats } \\
\text { Diversificados; } \\
\text { disponibilidade de } \\
\text { habitats insuficiente; } \\
\text { substratos } \\
\text { frequentemente } \\
\text { modificados. }\end{array}$ & $\begin{array}{l}\text { Menos que } 10 \% \text { de } \\
\text { habitats diversificados; } \\
\text { ausência de habitats } \\
\text { óbvia; substrato rochoso } \\
\text { instável para fixação dos } \\
\text { organismos. }\end{array}$ \\
\hline $\begin{array}{l}\text { 12. Extensão d } \\
\text { rápidos }\end{array}$ & $\begin{array}{l}\text { Rápidos e corredeiras } \\
\text { bem desenvolvidas; } \\
\text { rápidos tão largos } \\
\text { quanto o rio e com o } \\
\text { comprimento igual } \\
\text { ao dobro da largura } \\
\text { do rio. }\end{array}$ & $\begin{array}{l}\text { Rápidos com a } \\
\text { largura igual à do } \\
\text { rio, mas com } \\
\text { comprimento menor } \\
\text { que o dobro da } \\
\text { largura do rio. }\end{array}$ & $\begin{array}{l}\text { Trechos rápidos } \\
\text { podem estar ausentes; } \\
\text { rápidos não tão largos } \\
\text { quanto o rio e seu } \\
\text { comprimento menor } \\
\text { que o dobro da largura } \\
\text { do rio. }\end{array}$ & $\begin{array}{l}\text { Rápidos ou corredeiras } \\
\text { inexistentes. }\end{array}$ \\
\hline $\begin{array}{l}\text { 13. Frequências de } \\
\text { rápidos }\end{array}$ & $\begin{array}{l}\text { Rápidos } \\
\text { relativamente } \\
\text { frequentes; distância } \\
\text { entre rápidos } \\
\text { dividida pela largura } \\
\text { do rio entre } 5 \text { e } 7 .\end{array}$ & $\begin{array}{l}\text { Rápidos não } \\
\text { frequentes; } \\
\text { distância entre } \\
\text { rápidos dividida } \\
\text { pela largura do rio } \\
\text { entre } 7 \text { e } 15 .\end{array}$ & $\begin{array}{l}\text { Rápidos ou corredeiras } \\
\text { ocasionais; habitats } \\
\text { formados pelos } \\
\text { contornos do fundo; } \\
\text { distância entre rápidos } \\
\text { dividida pela largura } \\
\text { do rio entre } 15 \text { e } 25 \text {. }\end{array}$ & $\begin{array}{l}\text { Geralmente com lâmina } \\
\text { d'água "lisa" ou com } \\
\text { rápidos rasos; pobreza } \\
\text { de habitats; distância } \\
\text { entre rápidos dividida } \\
\text { pela largura do rio maior } \\
\text { que } 25 .\end{array}$ \\
\hline $\begin{array}{l}\text { 14. Tipos d } \\
\text { substrato }\end{array}$ & $\begin{array}{l}\text { Seixos abundantes } \\
\text { (prevalecendo em } \\
\text { nascentes). }\end{array}$ & $\begin{array}{l}\text { Seixos abundantes; } \\
\text { cascalho comum. }\end{array}$ & $\begin{array}{l}\text { Fundo formado } \\
\text { predominantemente } \\
\text { por cascalho; alguns } \\
\text { seixos presentes. }\end{array}$ & $\begin{array}{l}\text { Fundo pedregoso; seixos } \\
\text { ou lamoso. }\end{array}$ \\
\hline $\begin{array}{l}\text { 15. Deposição } \\
\text { de lama }\end{array}$ & $\begin{array}{l}\text { Entre } 0 \text { e } 25 \% \text { do } \\
\text { fundo coberto por } \\
\text { lama. }\end{array}$ & $\begin{array}{l}\text { Entre } 25 \text { e } 50 \% \text { do } \\
\text { fundo coberto por } \\
\text { lama. }\end{array}$ & $\begin{array}{l}\text { Entre } 50 \text { e } 75 \% \text { do } \\
\text { fundo coberto por } \\
\text { lama. }\end{array}$ & $\begin{array}{l}\text { Mais de75\% do fundo } \\
\text { coberto por lama. }\end{array}$ \\
\hline $\begin{array}{l}16 . \quad \text { Depósito } \\
\text { sedimentares }\end{array}$ & $\begin{array}{l}\text { Menos de 5\% do } \\
\text { fundo com deposição } \\
\text { de lama; ausência de } \\
\text { deposição nos } \\
\text { remansos. }\end{array}$ & $\begin{array}{l}\text { Alguma evidência de } \\
\text { modificação no } \\
\text { fundo, } \\
\text { principalmente } \\
\text { como aumento de } \\
\text { cascalho, areia ou } \\
\text { lama; } 5 \text { a } 30 \% \text { do } \\
\text { fundo afetado; suave } \\
\text { deposição nos } \\
\text { remansos. }\end{array}$ & $\begin{array}{l}\text { Deposição moderada } \\
\text { de cascalho novo, areia } \\
\text { ou lama nas margens; } \\
\text { entre } 30 \text { a } 50 \% \text { do } \\
\text { fundo afetado; } \\
\text { deposição moderada } \\
\text { nos remansos. }\end{array}$ & $\begin{array}{l}\text { Grandes depósitos de } \\
\text { lama, maior } \\
\text { desenvolvimento das } \\
\text { margens; mais de } 50 \% \\
\text { do fundo modificado; } \\
\text { remansos ausentes } \\
\text { devido à significativa } \\
\text { deposição de sedimentos. }\end{array}$ \\
\hline
\end{tabular}


Tabela 2: Protocolo de Avaliação Rápida da Diversidade de Habitats em trechos de bacias hidrográficas. (Obs.: 5 pontos (situação natural), 3, 2 e 0 pontos (situações leve ou severamente alteradas). Fonte: Autor do Trabalho (continuação)

\begin{tabular}{|c|c|c|c|c|}
\hline \multirow[t]{2}{*}{ PARÂMETROS } & \multicolumn{3}{|c|}{ PONTUAÇÃO } & \multirow[b]{2}{*}{0 ponto } \\
\hline & 5 pontos & 3 pontos & 2 pontos & \\
\hline $\begin{array}{l}\text { 17. Alterações no } \\
\text { canal do rio }\end{array}$ & $\begin{array}{l}\text { Canalização } \\
\text { (retificação) ou } \\
\text { dragagem ausente ou } \\
\text { mínima; rio com } \\
\text { padrão normal. }\end{array}$ & $\begin{array}{l}\text { Alguma canalização } \\
\text { presente, } \\
\text { normalmente } \\
\text { próximo à } \\
\text { construção de } \\
\text { pontes; evidência de } \\
\text { modificações há } \\
\text { mais de } 20 \text { anos. }\end{array}$ & $\begin{array}{l}\text { Alguma modificação } \\
\text { presente nas duas } \\
\text { margens; } 40 \text { a } 80 \% \text { do } \\
\text { rio modificado. }\end{array}$ & $\begin{array}{l}\text { Margens modificadas; } \\
\text { acima de } 80 \% \text { do rio } \\
\text { modificado. }\end{array}$ \\
\hline $\begin{array}{l}18 \text { Características } \\
\text { do fluxo das águas }\end{array}$ & $\begin{array}{l}\text { Fluxo relativamente } \\
\text { igual em toda a } \\
\text { largura do rio; } \\
\text { mínima quantidade } \\
\text { de substrato exposta. }\end{array}$ & $\begin{array}{l}\text { Lâmina d'água } \\
\text { acima de } 75 \% \text { do } \\
\text { canal do rio; ou } \\
\text { menos de } 25 \% \text { do } \\
\text { substrato exposto. }\end{array}$ & $\begin{array}{l}\text { Lâmina d'água entre } \\
25 \text { e } 75 \% \text { do canal do } \\
\text { rio, e/ou maior parte } \\
\text { do substrato nos } \\
\text { "rápidos" exposto. }\end{array}$ & $\begin{array}{l}\text { Lâmina d'água escassa e } \\
\text { presente apenas nos } \\
\text { remansos. }\end{array}$ \\
\hline $\begin{array}{l}\text { 19. Presença de } \\
\text { mata ciliar }\end{array}$ & $\begin{array}{l}\text { Acima de } 90 \% \text { com } \\
\text { vegetação ripária } \\
\text { nativa, incluindo } \\
\text { árvores, arbustos ou } \\
\text { macrófitas; mínima } \\
\text { evidência de } \\
\text { desflorestamento; } \\
\text { todas as plantas } \\
\text { atingindo a altura } \\
\text { "normal". }\end{array}$ & $\begin{array}{l}\text { Entre } 70 \text { e } 90 \% \text { com } \\
\text { vegetação ripária } \\
\text { nativa; } \\
\text { desflorestamento } \\
\text { evidente, mas não } \\
\text { afetando o } \\
\text { desenvolvimento da } \\
\text { vegetação; maioria } \\
\text { das plantas } \\
\text { atingindo a altura } \\
\text { "normal". }\end{array}$ & $\begin{array}{l}\text { Entre } 50 \text { e } 70 \% \text { com } \\
\text { vegetação ripária } \\
\text { nativa; } \\
\text { desflorestamento } \\
\text { óbvio; trechos com } \\
\text { solo exposto ou } \\
\text { vegetação eliminada; } \\
\text { menos da metade das } \\
\text { plantas atingindo a } \\
\text { altura "normal". }\end{array}$ & $\begin{array}{l}\text { Menos de } 50 \% \text { da mata } \\
\text { ciliar nativa de floresta- } \\
\text { mento muito acentuado. }\end{array}$ \\
\hline $\begin{array}{l}20 \text { Estabilidade das } \\
\text { margens }\end{array}$ & $\begin{array}{l}\text { Margens estáveis; } \\
\text { evidência de erosão } \\
\text { mínima ou ausente; } \\
\text { pequeno potencial } \\
\text { para problemas } \\
\text { futuros. Menos de 5\% } \\
\text { da margem afetada. }\end{array}$ & $\begin{array}{l}\text { Moderadamente } \\
\text { estáveis; pequenas } \\
\text { áreas de erosão } \\
\text { frequentes. Entre } 5 \\
\text { e 30\% da margem } \\
\text { com erosão. }\end{array}$ & $\begin{array}{l}\text { Moderadamente } \\
\text { instável; entre } 30 \text { e } \\
60 \% \text { da margem com } \\
\text { erosão. Risco elevado } \\
\text { de erosão durante } \\
\text { enchentes. }\end{array}$ & $\begin{array}{l}\text { Instável; muitas áreas } \\
\text { com erosão; frequentes } \\
\text { áreas descobertas nas } \\
\text { curvas do rio; erosão } \\
\text { óbvia entre } 60 \text { e } 100 \% \text { da } \\
\text { margem. }\end{array}$ \\
\hline $\begin{array}{l}\text { 21. Extensão de } \\
\text { mata ciliar }\end{array}$ & $\begin{array}{l}\text { Largura da vegetação } \\
\text { ripária maior que } 18 \\
\text { m; sem influência de } \\
\text { atividades antrópicas } \\
\text { (agropecuária, } \\
\text { estradas, etc.). }\end{array}$ & $\begin{array}{l}\text { Largura da } \\
\text { vegetação ripária } \\
\text { entre } 12 \text { e } 18 \text { m; } \\
\text { mínima influência } \\
\text { antrópica. }\end{array}$ & $\begin{array}{l}\text { Largura da vegetação } \\
\text { ripária entre } 6 \text { e } 12 \text { m; } \\
\text { influência antrópica } \\
\text { intensa. }\end{array}$ & $\begin{array}{l}\text { Largura da vegetação } \\
\text { ripária menor que } 6 \text { m; } \\
\text { vegetação restrita ou } \\
\text { ausente devido à } \\
\text { atividade antrópica. }\end{array}$ \\
\hline $\begin{array}{l}\text { 22. Presença de } \\
\text { plantas aquáticas }\end{array}$ & $\begin{array}{l}\text { Pequenas macrófitas } \\
\text { aquáticas e/ou } \\
\text { musgos distribuídos } \\
\text { pelo leito. }\end{array}$ & $\begin{array}{l}\text { Macrófitas aquáticas } \\
\text { ou algas } \\
\text { filamentosas ou } \\
\text { musgos distribuídos } \\
\text { no rio, substrato } \\
\text { com perifiton. }\end{array}$ & $\begin{array}{l}\text { Algas filamentosas ou } \\
\text { macrófitas em poucas } \\
\text { pedras ou alguns } \\
\text { remansos, perifiton } \\
\text { abundante e biofilme. }\end{array}$ & $\begin{array}{l}\text { Ausência de vegetação } \\
\text { aquática no leito do rio } \\
\text { ou grandes bancos } \\
\text { macrófitas (p.ex. } \\
\text { aguapé). }\end{array}$ \\
\hline
\end{tabular}

Fonte: Autor do Trabalho

Tendo como base os resultados coletados podem ser averiguado que de acordo com a tabela elaborada por Callisto o córrego do Rio Cereja, que cruza o bairro do Alegre no município de Bragança - PA se encontra em situação seriamente impactado, onde foi possível ver que muitos aspectos de eutrofização, perda da biodiversidade local fizeram com que em conjunto a atividades de impactos negativos acarretassem na perca daquele corpo hídrico. Onde é visto que com a perda do solo, ao qual se tornou arenoso, antropização de alguns pontos acabou que facilitasse o aumento da perda de espécies vegetativas 
e da fauna, o que trouxe assim aumento de aspectos não locais, como vetores de doenças. Que acabou afetando a comunidade que cerca esse córrego. Podendo transmitir diversas doenças e acúmulos que acabam se tornando prejudiciais ao ambiente e comunidade.

\section{CONCLUSÃO}

Logo, o Rio Cereja e seus afluentes mostrou que suas margens e seu corpo apresentou uma ocupação desordenada ocasionada pela falta de um devido planejamento urbano que não se preocupou com os aspectos daquele corpo hídrico e não conservou a mata ciliar que a circunda. Determinando assim grandes riscos a população, haja vista que no córrego no bairro do Alegre muitas vezes dentro do corpo hídrico é possível analisar e averiguar a presença de efluentes doméstico das famílias que descartam seus produtos de forma errônea e sem preocupação, além dos descartados por outros bairros que acaba se acumulando no local.

Esse descuido oriundo do mal plano de gerenciamento governamental e despreocupação da população fez com que contribuísse para a degradação ambiental do local, analisando que diversos tipos de resíduos acabam entrando em contato com o corpo hídrico.

Vale se ressaltar que as margens do Rio Cereja são consideradas área de preservação permanente - APP (BRASIL - 2012), então é de suma importância que o poder municipal fiscalize e elabore projetos e planos urbanos de Bragança, para que se tenha a devida recuperação e o fim do desmatamento e ocupação das margens.

Com a realização desta pesquisa através do método do protocolo de Callisto, conclui-se que o afluente do rio Cereja, situado no Bairro do Alegre, sofre impacto por ações antrópicas, principalmente pelo descarte inadequado de resíduos domésticos que contaminam a água e o solo. Foi possível analisar que o ambiente selecionado apresenta uma somatória de 21 pontos, que se enquadra ao um ambiente impactado. E que as ações da população e um mal gerenciamento acabou contribuindo para o processo de eutrofização do córrego e de todo o rio.

Todavia, a situação ainda apresenta possíveis soluções, como parcerias entre distintos órgãos públicos e privados, para acentuar uma conscientização ambiental entre os moradores, desde o reuso de certos materiais, até a forma menos agravante do despejo de determinadas substâncias. Pode-se propor também uma possível implantação de um sistema de micro drenagem no efluente analisado em conjunto aos demais efluentes domésticos que cercam a cidade de Bragança, já que a localidade não possui saneamento adequado, o que dificulta ainda mais na problemática.

\section{REFERÊNCIAS}

[1] ABNT (Associação Brasileira de Normas Técnicas). NBR 9.898. Preservação e Técnicas de Abordagem de Efluentes Líquidos e Corpos Receptores. ABNT, Rio de Janeiro, 1987.

[2] BRASIL. Lei no 12.651 - Dispõe sobre a proteção da vegetação nativa; revoga as Leis 4.771, de 15 de setembro de 1956, e 7.754, de 14 de abril de 1989, e a Medida Provisória no 2.166-67, de 24 de agosto de 2001; e dá outras providências. Planalto, 2012.

[3] CALliSTO, M.; FERREIRA, W.; MORENO, P.; GOULART, M.; PETRUCIO, M.. Aplicação de um protocolo de avaliação rápida da diversidade de habitats em atividades de ensino e pesquisa. Acta Limnologica Brasiliensia, v.14, n. 1 p.91-98, 2002.

[4] CARVAlHO, A.. Princípios Básicos do Saneamento do Meio. Editora Senac São Paulo, edição 10ª , 2010.

[5] CONAMA, Conselho Nacional do Meio Ambiente. Resolução CONAMA № 357. Ministério do Meio Ambiente MMA, n.53, p.58-63, 2005.

[6] IBGE - Instituto Brasileiro de Geografia e Estatística. Cidades/População, 2015 e 2016. IBGE, 2016.

[7] JORDÃO, E. P.; PESSOA, C. A.. Tratamento de Esgotos Domésticos. Editora Synergia, edição 6ạ , 2009.

[8] MMA. Plano Nacional de Recursos Hídricos. Ministério do Meio Ambiente, 2006.

[9] OLIVEIRA, T. C.; WOLLMANN, A. C.. Eventos de precipitação extrema e impactos meteóricos na bacia hidrográfica do igarapé Cereja, área urbana de Bragança - PA durante o inverno amazônico de 2014. Revista do departamento de geografia, p.51-69, 2016.

[10] TUCCI, E. M.. Gestão de Águas Pluviais Urbanas. Global Warter Partnership - UNESCO, 2005. 


\section{Capítulo 6}

\section{Sistema de tratamento de esgoto total com reator UASB em comunidades rurais no Semiárido Baiano}

\section{Clérison dos Santos Belém \\ André Azevedo Rocha \\ Miriam Cleide Cavalcante Amorim \\ Carlos Laécio Evangelista Franca}

Resumo: A ausência do saneamento básico, sobretudo no meio rural, bem como a inexistência de políticas apropriadas à realidade das comunidades rurais, é um problema a ser enfrentado por estas populações. 0 objetivo desse trabalho é divulgar estratégias de saneamento rural, através da aplicação de sistema de tratamento de esgotos domésticos e reúso da água, como tecnologias descentralizadas aplicadas na agricultura familiar no território do Sertão do São Francisco, Norte da Bahia. 0 sistema teve sua viabilidade atestada no território supracitado e, por isso, foi bem divulgada; os saberes obtidos estão sendo utilizados na elaboração de projetos e na formação de pessoas sobre esse tema. Uma perspectiva futura é que seja possível o tratamento e disposição final de esgotos de origem doméstica nas comunidades rurais, tendo por base o reúso de águas servidas, via tecnologias já existentes e outras a serem desenvolvidas ou adaptadas. Para isso, faz-se indispensável o financiamento de políticas públicas voltadas para o saneamento básico rural apropriado.

Palavras-chave: Esgoto total; Reúso agrícola; Saneamento rural. 


\section{INTRODUÇÃo}

Figura 1. Sistema de tratamento esgoto total com Reator UASB

A ausência do saneamento básico é um problema nos municípios brasileiros, e nas comunidades rurais tal problema é ainda maior, devido à inexistência de sistemas de abastecimento, coleta e tratamento de resíduos sólidos e líquidos. De acordo com o Instituto Trata Brasil (2017) e o Ministério do Desenvolvimento Regional MDR (2017), 60,2\% da população brasileira tem acesso à coleta de esgoto, sendo que quase 100 milhões de pessoas não tem acesso a este serviço. Na região Nordeste, 26,9\% das pessoas são atendidas apenas com a coleta de esgotos. Com relação ao tratamento, no Brasil 45,1\% dos esgotos são tratados, sendo este índice correspondente a 34,7\% na região Nordeste.

De acordo com Medeiros et. al., (2014), apenas 243 municípios da região semiárida possuem sistema de coleta de esgoto, e cerca de 10,9 milhões de habitantes não dispõem deste serviço, sendo utilizadas fontes alternativas para transporte e destinação final, a exemplo das fossas sépticas, sumidouros, valas a céu aberto e/ou lançamento direto nos corpos hídricos. Na zona rural, a situação é ainda mais agravante, pois não existe política pública para adoção de sistemas de tratamento de esgoto na região, sendo possível verificar, ainda nos dias atuais, o despejo de águas provenientes de pias, chuveiro e da lavagem de roupas, em valas a céu aberto, criando poças de água e infiltrando no solo, sem nenhum tipo de tratamento e aproveitamento, além de ser um ambiente propício para insetos transmissores de doenças.

Nos últimos anos vem crescendo a discussão sobre o destino responsável e ecológico das águas servidas. Ressalta-se que no meio rural do Semiárido, a grande maioria das residências não dispõem sequer de sanitários. Segundo dados do IBGE (PNAD/2014), apenas 33\% dos domicílios rurais estão ligados a redes de abastecimento de água, apenas $8 \%$ têm conexão com rede coletora de esgoto e $27 \%$ contam com coleta direta de resíduos sólidos. Quase a metade (49,9\%) destes domicílios ainda usa fossas rudimentares para o tratamento do esgoto. Além disso, a discussão continua sem muitas novidades nas tecnologias de tratamento de esgotos, baseadas, majoritariamente, em concentrar os esgotos de toda a cidade em gigantes bacias de decantação e posterior lançamento dessas águas nos cursos de água da região.

0 reúso controlado de águas economiza o uso das águas de chuva, mananciais e poços, para usos mais restritivos, e, devido à menor geração de efluentes finais, evita a proliferação de doenças causadas por parasitas que acometem principalmente as crianças. Evita a poluição ambiental, que também contribui para a crescente escassez de água, em consequência da degradação da sua qualidade.

O objetivo desse trabalho é divulgar estratégias de saneamento rural, por meio de um sistema de tratamento de esgotos domésticos e reúso da água servida na agricultura familiar de forma descentralizada, implantado no território Sertão do São Francisco, Norte da Bahia.

\section{MATERIAL E MÉTODOS}

Há um bom tempo o IRPAA já utilizava em seu centro de formação, uma Bacia de Evapotranspiração (BET), que tratava apenas águas oriundas de bacias sanitárias (vaso). Depois passou-se a buscar a diversificação com a instalação do sistema Bioágua e Esgoto total, através do reator anaeróbio de fluxo ascendente (UASB), visando contribuir para a ampliação das possibilidades técnicas e/ou metodológicas de saneamento rural, em vista às diversas realidades sócio ambientais do Semiárido. Assim, nos últimos anos o IRPAA, junto com os agricultores e entidades de ensino e pesquisa Universidade Federal do Vale do São Francisco - UNIVASF e Instituto Nacional do Semiárido - INSA, vem experimentando e replicando estes sistemas simplificados de tratamento de esgoto rural, adaptados à realidade local, para fins de reúso de águas servidas domésticas na agricultura familiar. As tecnologias testadas recentemente foram implementadas a campo em Juazeiro, Curaçá e Sento Sé, ambas localizadas no território Sertão do São Francisco, região norte da Bahia.

Foram implementados quatro sistemas de tratamento de esgoto total. Nesses sistemas, o tratamento ocorre em três etapas: a) preliminar, através da caixa de gordura, para retenção da gordura por flotação, e através do tanque séptico, que tem a função de remover os sólidos suspensos; b) secundário, com decomposição anaeróbia em reator UASB e remoção da matéria orgânica; e c) terciário, através das lagoas de polimento para eliminação dos patógenos (Figura 1) 


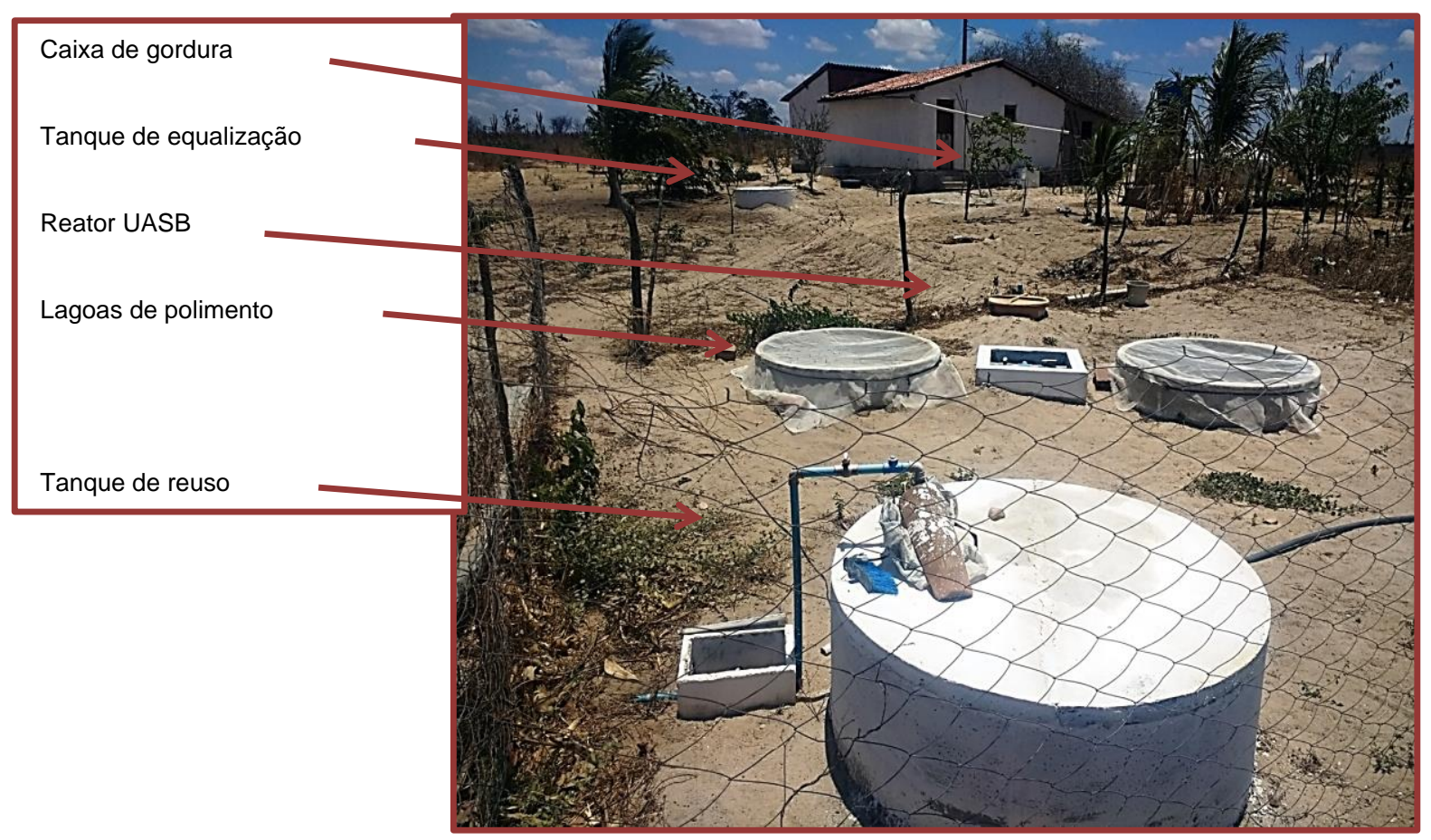

O conhecimento do Sistema UASB se deu em visita técnica realizada em comunidades de atuação do Instituto Nacional do Semiárido (INSA) e Programa de Aplicação de Tecnologias Apropriadas (Patac), nos municípios de Campina Grande e Cubatí - Paraíba.

Através da parceria entre o IRPAA e a Univasf, foram coletadas amostras do esgoto antes e após o sistema de tratamento, para verificação da eficiência do mesmo. Para tanto, foram realizadas análises físicoquímicas e microbiológicas. Para avaliação dos aspectos sanitários foi determinado como parâmetro microbiológico a Escherichia coli. Na avaliação da remoção da matéria orgânica, determinaram-se os parâmetros da Demanda Química de Oxigênio (DQO), a Demanda Bioquímica de Oxigênio (DBO) e os sólidos suspensos. Os sólidos dissolvidos foram determinados para avaliar possíveis riscos de obstrução dos sistemas de irrigação, no caso de se reutilizar o esgoto tratado para fins agrícolas. Todas as análises seguiram a metodologia do Standard Methods for The Examination of Water and Wastewater (APHA, 2012). 0 monitoramento da ETE foi realizado nos meses de junho, julho e agosto de 2019.

\section{RESULTADOS E DISCUSSÃO}

A tecnologia de reúso de água foi aceita com facilidade pelas famílias no campo, devido ser de fácil construção, manutenção e manejo, que pode ser realizado pela própria família, sem adição de qualquer produto químico. Ao mesmo tempo em que aumentou a disponibilidade de água para utilizar nos quintais das propriedades, garantiu a saúde da população e a integridade ambiental dessas localidades. Segundo Serafim (2013), as experiências de tratamento de esgoto têm contribuído para a melhoria da vida dos agricultores, respeitando seus valores tradicionais e culturais, e muitas vezes possibilitando a autonomia e o bem viver das famílias.

A Tabela 1 apresenta a evolução da eficiência da ETE para os parâmetros avaliados. Observa-se que nos dois primeiros meses não houve remoções dos coliformes, e que no terceiro mês o sistema se ajustou, alcançando remoções de 95 e 93\%, estando na faixa recomendada pela Organização Mundial de Saúde OMS para reuso restrito. Já para as bactérias heterotróficas, as remoções variaram entre 46 e 98\%.

Na primeira coleta a eficiência de remoção de matéria orgânica, a DQO foi da ordem de 93\% e a DBO de $81 \%$, esta última sendo maior do que a eficiência de remoção mínima (60\%) preconizada pela Resolução 
CONAMA no 430/2011. Quanto aos sólidos sedimentares, a remoção foi de 99\% ao longo do sistema de tratamento.

Tabela 1. Eficiência do sistema de tratamento de esgoto total

\begin{tabular}{|c|c|c|c|}
\hline \multirow{3}{*}{ Parâmetros } & \multicolumn{3}{|c|}{ Eficiência remoção \% } \\
\hline & $1^{\text {a }}$ Coleta & $2^{\text {a }}$ Coleta & $3^{\text {a }}$ Coleta \\
\hline & $14 / 06 / 2019$ & $12 / 07 / 2019$ & $16 / 08 / 2019$ \\
\hline Col. Term. (NMT/100 mL) & 0 & 0 & 95 \\
\hline E.Coli (NMT/100 mL) & 0 & 0 & 93 \\
\hline Heterotróficas (UFC/mL) & 98 & 46 & 70 \\
\hline Demanda Química de Oxigênio (mg/L) & 93 & 46 & 44 \\
\hline Demanda Bioquímica de Oxigênio (mg/L) & 81 & 55 & 40,0 \\
\hline Sólidos Sedimentáveis (mL/L) & 99 & 99 & $\ldots$ \\
\hline
\end{tabular}

Diante dos resultados apresentados, o sistema de tratamento de esgoto total apresenta segurança sanitária e eficiência de remoção de material orgânico, permitindo a instalação de modo descentralizado, no âmbito familiar, atendendo à realidade da disposição geográfica das habitações no campo do Semiárido, que se configuram por casas dispersas, bem como adaptação ao ambiente quente, de intensa radiação e evaporação, e solos relativamente rasos.

A eficiência do sistema também apresenta o potencial para reúso agrícola do esgoto tratado, principalmente pelas remoções de microrganismos patogênicos, associados aos aspectos sanitários do efluente, bem como as remoções de material orgânico e sólidos sedimentáveis, ambas associadas ao sistema de irrigação (segundo Ayres e Westcot (1991) e USEPA (2004)), pois evitam o entupimento do sistema. Os dados mostraram que há restrição para reúso em culturas consumidas cruas, como as folhosas, assim como os tubérculos, segundo os parâmetros avaliados.

A gestão da família é um ponto essencial no bom funcionamento do sistema de tratamento do esgoto total para reúso agrícola, pois necessita de uma regular manutenção das estruturas que compõem o sistema, tais como: limpeza da caixa de gordura, retirada do excesso de lodo do reator, fechar e abrir registros das lagoas de polimento, respeitando o tempo mínimo de cinco dias de repouso, e manejar corretamente o sistema de bombeamento e irrigação.

Essas ações culminam para a centralidade nas formações, oficinas e espaços de discussão das temáticas de saneamento rural, questões ambientais e práticas de sustentabilidade, que contribuem para a convivência com o Semiárido, que na maioria das vezes não chega a ser discutido no campo, mas não podem ser tratadas como um pacote tecnológico pronto para todas as situações. Existe uma variedade de tecnologias para tratamento de esgoto em comunidades rurais (TONETTI, 2018); a escolha da tecnologia ideal requer uma avaliação de diversas variáveis simultaneamente como: custo de implantação, área disponível para o sistema, tipo de solo e profundidade, declividade do terreno, tipo de esgoto a ser tratado, existência de banheiro com águas encanadas e demais variáveis local.

Considerando uma casa com cinco pessoas na zona rural do Semiárido, é possível reaproveitar em média 200 litros/dia e 6.000 litros/mês de esgoto tratado, volume esse considerável para as famílias que vivem em regiões de sequeiro no Semiárido Brasileiro, o que equivale a 1,4 cisternas dos tipos calçadão ou enxurrada. Essa água reaproveitada da residência está sendo utilizada nos quintais através de SAF Sistema Agro Florestal, para produção de fruteiras e plantas forrageiras; garantindo a segurança alimentar da família e dos animais. E está sendo distribuída a partir de um sistema simplificado de irrigação, contendo mangueiras e gotejadores; as principais culturas implantadas foram a palma forrageira, o mandacaru, o sorgo, a leucena, a moringa para alimentação dos caprinos e ovinos, e a irrigação de plantas frutíferas, que já existiam nos quintais das casas.

\section{CONCLUSÃO}


A tecnologia se mostrou viável e apropriada ao Semiárido, no campo do tratamento de resíduos líquidos, apresentando eficiência de remoção de matéria orgânica acima de 80\% e remoção de microorganismos patógenos. Dessa forma, a estratégia de descentralização de abastecimento e tratamento de água nas comunidades rurais do Semiárido se mostra cada vez mais viável, sempre em busca da universalização das mesmas e da sustentabilidade local, com as famílias envolvidas em todos os processos.

0 monitoramento do sistema permitiu observar que o esgoto tratado apresenta potencial para o reúso agrícola restrito a culturas forrageiras, frutíferas, cerealíferas, madeireiras e oleaginosas, atendendo aos aspectos sanitários e de bom funcionamento do sistema de irrigação.

Uma perspectiva futura é a de que seja possível o tratamento e disposição final de esgotos de origem doméstica nas comunidades rurais, em um agrupamento de residências e, também, de pequenos coletivos, como escolas e centros comunitários. Já existem tecnologias capazes de realizar esse processo, mas que dependem de um financiamento e políticas públicas voltadas para o saneamento básico rural.

\section{REFERÊNCIA}

[1] American Water Works Association; Water Environment Federation. Standard methods for the examination of water and wastewater.23. Ed. American Public Health Association, Washington, DC, 2012.

[2] Instituto Trata Brasil. Dados sobre saneamento básico do país. Acesso em: 04 de abr. 2019. http://www.tratabrasil.org.br/saneamento/principais-estatisticas/no-brasil/esgoto

[3] Medeiros, S. S.; Salcedo, I. H.; Santos, D. B.; Batista, R. O.; Santos Junior, J. A.; Lima, R. C. C.; Perez-Marin, A. M. (2014), Esgotamento Sanitário: Panorama para o Semiárido Brasileiro. 1. ed. Campina Grande: Instituto Nacional do Semiárido, v. 1.63p.

[4] MINISTÉRIO DO MEIO AMBIENTE - MMA. CONSELHO NACIONAL DO MEIO AMBIENTE - CONAMA. Resolução no 430/11. Dispõe sobre as condições e padrões de lançamento de efluentes, complementa e altera a Resolução no 357, de 17 de março de 2005, do Conselho Nacional do Meio Ambiente-CONAMA. Brasília, DF, 2011.

[5] MINISTÉRIO DO DESENVOLVIMENTO REGIONAL - MDR. Secretaria Nacional de Saneamento (SNS). Diagnóstico sobre as condições de saneamento no Brasil. Brasília, 2017.

[6] Pesquisa Nacional por Amostra de Domicílios: síntese de indicadores 2014 / IBGE, Coordenação de Trabalho e Rndimento - Rio de Janeiro, 2015.

[7] SERAFIM, Milena P.; DIAS, Rafael de B. Tecnologia social e tratamento de esgoto na área rural. Instituto Polis, São Paulo/SP, 2013.

[8] TONETTI, Adriano Luiz, et al. Tratamento de esgotos domésticos em comunidades isoladas: referencial para a escolha de soluções. Biblioteca/Unicamp, Campinas-SP, 2018.

[9] World Health Organization (WHO). Guidelines for the safe use of wastewater, excreta and greywater. Excreta and greywater use in agriculture. v. IV. Geneva: World Health Organization, 2006. 


\section{Capítulo 7}

Comportamento de aves em áreas urbanas: Um estudo de caso

\section{Rafael Natal Xavier Souza}

Rita Tassiana da Costa

Regiane Aparecida Negri

Resumo: Muitas espécies de pássaros vem se mostrando em declínio devido ao aumento do processo de urbanização e destruição de ambientes naturais. 0 presente trabalho objetivou resgatar alguns autores que relatam a temática e propõe algumas hipóteses aos problemas apresentados. Por fim, podemos notar que a diminuição de ambientes naturais, consequentemente se mostra responsável por perdas de espécies e habitats naturais, o que é extremamente preocupante considerando a importância de toda nossa fauna.

Palavras-chave: Impactos ambientais; Perda de biodiversidade; Diversidade de espécies; Pássaros. 


\section{INTRODUÇÃO}

A interação dos fatores socioeconômicos, ambientais e biológicos resultam no ambiente urbano, no qual o meio físico predomina o homem sendo ele responsável por variadas alterais que interferem na qualidade dos seres (LOMBARDO, 1990)

As atividades humanas nos dias de hoje são responsáveis por grandes alterações, tendo como principal o processo de urbanização, sendo muito importante a realização de trabalhos que avaliem a mudança da fauna por conta da influência humana e os recursos que são necessários para sobreviver.

Em áreas onde a arborização é realizada são utilizadas poucas espécies além de serem utilizadas de forma descontínua, o que é responsável pela perda de biodiversidade, ou seja, as espécies que tem a possibilidade de visitar áreas urbanas não o fazem de fato, pois a fonte de alimentação é escassa e os abrigos precários, devido este fato, pouca são as espécies sobreviventes em áreas urbanas (BRUN et al., 2007).

As áreas naturais sofrem grande impacto pelas ações antrópicas, e dessa maneira diminuem a qualidade e a quantidade de recursos disponíveis, fazendo com que várias espécies de pássaros silvestres busquem novos locais para abrigo, alimentação e locais para nidificação. Nesse sentido, as áreas urbanas são muitas vezes o destino desses animais que acabam se instalando em praças, jardins e parques de variadas cidades (Souza et al., 1995).

Segundo Borleto et al., (2006) variadas cidades brasileiras não apresentam um plano de arborização urbana que seja adequado, já que na maioria das vezes os projetos têm como base conhecimentos empíricos, assim não apresentando um conhecimento verdadeiro sobre o tema. Devido a este fato a arborização se torna ineficiente e com isso não trazendo os benefícios esperados. 0 mau manejo e planejamento apenas pode ser resolvido com o auxílio da administração pública municipal, para que políticas públicas sejam definidas.

Para os passarinhos serem atraídos para as grandes cidades geralmente a população utiliza de vasilhas com sementes e frutas ou até mesmo bebedores com água. A população faz ligação da presença dos pássaros em casas devido a árvores frutíferas, por exemplo. Segundo especialistas houve um aumento de aves na cidade, e devido a mídia essa presença se tornou mais notável. Sempre é possível estudar um espaço para descobrir maiores informações sobre a área. Acredita-se que a principal mudança das aves para a cidade seja devido a uma mudança cultural que houve, assim havendo uma maior preservação dos mesmos. Outra questão é que as aves que se encontram em áreas urbanas geralmente são de espécies que habitam áreas verdes, mas também podem habitar a cidade, mesmo que por uma ocasião, ou até mesmo são atraídas pelas áreas verdes existentes dentro das cidades (GUIMARÃES, 2006).

Scherer et al., (2006) realizou um estudo que mostrava a avifauna encontrada no Parque Mascarenhas de Morais (PMM) que é situado no norte de Porto Alegre, além das espécies nidificantes da área. Dentre as espécies encontradas estava a Sicalis flaveola. $\mathrm{O}$ autor afirma a importância dos estudos em áreas úmidas que são situadas em áreas urbanizadas, para que assim ocorra a conservação e preservação de espécies tanto vegetais quanto animais. 0 parque do estudo citado, PMM, mesmo tendo uma significativa influência humana possibilitou as aves, em maio ao centro urbano, espaço para nidificação, dormitório e alimentação, assim este parque merecendo uma atenção maior para a preservação.

A Sicalis flaveola se encaixa em uma das aves mais valorizadas para o comércio, já que despertam interesse nos compradores devido a sua coloração, beleza e canto, desta maneira sendo criadas em cativeiros, como animais de estimação (RIBEIRO \& SILVA, 2007). A distribuição dos indivíduos dessa espécie ocorre praticamente em todo o território brasileiro, com baixa distribuição na região Amazônia. Em território internacional também podemos ver uma ampla gama de indivíduos presentes na Venezuela, Colômbia, Guianas, Equador, Peru, Bolívia, Paraguai, Uruguai e Argentina. 0 canário-da-terra-verdadeiro possui como habitat bordas de matas, campos naturais e pastagens, áreas de cerrado e caatinga, além de áreas cultivadas. Devido à grande antropização do homem, a espécie também vem se dispersando e ocupando lugares no meio urbano, como já registrado em várias cidades do País, em especial em parques de São Paulo e Curitiba.

Tendo isso como base, o principal objetivo deste trabalho foi fazer um levantamento bibliográfico a respeito do comportamento das aves nas áreas urbanas. Dessa forma, os resultados desta pesquisa foram apresentados na $8^{\circ}$ Jornada Científica e Tecnológica do Ifsuldeminas com relevância significativa ao tema estudado. 


\section{MATERIAIS E MÉTODOS}

0 presente trabalho é uma revisão de literatura, portando de maneira sucinta, foram feitas buscas de artigos, documentos, notas científicas a respeito do tema estudado.

As buscas tiveram início no dia 3 de agosto ao dia 30 de novembro do ano de 2015, com o horário fixo das 11:00 $\mathrm{h}$ às 13:00 $\mathrm{h}$, exceto nos finais de semanas. Foram utilizadas as seguintes bases de dados para busca: Google Acadêmico, Scielo, Periódicos CAPES/MEC.

Para uma busca mais ampla e precisa, foi especificado que a publicação poderia ser em português ou em inglês, não foi marcado ano de publicação, pois poderia haver algum arquivo mais antigo com informações úteis.

Para a escrita do trabalho todo utilizou a Sicalis flaveola L., ou popularmente conhecido como canarinhoda-terra, como espécie principal para a discussão, já que a mesma atualmente está ameaçada de extinção.

Na construção da introdução foi utilizado os seguintes termos: 'pássaros em áreas urbanas'; ' Sicalis flaveola L. em áreas urbanas'; 'Sicalis flaveola L. comportamento' na base de dados Google Acadêmico. A busca foi feita no dia 10 de agosto de 2015, das 7:00h até 12:00h.

Os termos utilizados nas bases de dados, para o referencial teórico, foram: 'comportamento de aves em áreas urbanas'; 'aves área urbana comportamento'; 'comportamento de aves em áreas urbanas'; 'comportamento de Sicalis flaveola L. em áreas urbanas: um estudo de caso'; 'canarinho da terra em áreas urbanas comportamento'; 'Sicalis flaveola L. em áreas urbanas'; estudo de caso de Sicalis flaveola L'; 'áreas urbanas Sicalis flaveola L'; 'estudo de caso canarinho da terra'; 'comportamento de pássaros em áreas urbanas'.

Após a análise de todo material encontrado por meio desta busca, apenas os arquivos que continham informações relevantes foram salvos para análises mais profundas.

\section{REFERENCIAL TEÓRICO E DISCUSSÃO}

\subsection{COMPORTAMENTO DE AVES EM ÁREA URBANA}

De acordo com Melles et al., (2003), as áreas urbanas causam a perda da diversidade ambiental, o que caracteriza a riqueza de espécies no ambiente. Segundo o autor as áreas urbanas que possuem remanescentes como florestas, rios e lagos abrigam um número maior de espécies.

Em um trabalho realizado no parque Ipanema do município de Ipatinga, foram encontradas 57 espécies pertencentes a 26 famílias. Segundo o autor, pelo tamanho da área foi considerado pequena a diversidade de espécie, além de baixa, atribui-se ao fato de que a transformação das áreas naturais causou o desaparecimento da diversidade de espécies (FUSCALDI \& LOURES-RIBEIRO, 2008)

De acordo com Villanueva \& Silva, (1995) a ação humana e por consequência suas alterações ambientais da área, acarretam uma menor riqueza e diversidade das espécies de aves, a mudança de uma região influencia a composição da avifauna. Fato que é confirmado por Mendonça-Lima \& Fontana, (2000) e Ausden, (2004), que afirma que as áreas abertas ocasionam uma simplificação do ambiente, diminuindo a disponibilidade de atrativos para as aves, entre eles os abrigo, alimentação e produção de ninhos.

Segundo Marzluff et al., (2001) os pesquisadores têm se interessado pela avifauna que é encontrada no ambiente urbano. Os principais trabalhos envolvendo áreas urbanas trazem basicamente as mudanças nos aspectos demográficos na diversidade e na mudança na diversidade das espécies de aves quando relacionadas com a urbanização.

Na região do Triângulo Mineiro/Alto Paranaíba as áreas verdes urbanas apresentam uma heterogeneidade de avifauna significativa. Uma parte das espécies lá encontradas podem ser consideradas endêmicas dessas áreas, pois são facilmente encontradas em todas estas (FRANCHIN, 2009).

Variadas espécies no Brasil, vem se tornando as mesmas que são encontradas em ambientes que já foram modificadas pelo homem. Por exemplo, a popularmente conhecida: pomba-asa-branca (Patagioenas picazuro), que colonizou a cidade de Uberlândia, isso ocorreu, acredita-se pela semelhança deste com o seu habitat original, outra questão que pode ser considerada é degradação do seu ambiente natural (FRANCHIN \& MARÇAL JÚNIOR, 2002; WILLIS \& ONIKI, 1987). 
Jenni \& Kéry (2003) afirma que é possível detectar o clima de um determinado ambiente através do comportamento de aves, uma vez que algumas, em especiais as migratórias, podem adiantar ou atrasar suas migrações.

É possível encontrar na literatura trabalhos que mostrem o comportamento das aves, mostrando o comportamento alimentício, seleção dos frutos e o papel que desenvolvem de frugivoria e quais as implicações que isso acarreta na dispersão de sementes e em ambientes urbanos e naturais.

Em estudos realizados por Villanueva \& Silva, (1995) foi demonstrado que em ambientes urbanos, insetívoros e onívoros são representados por espécies de pássaros generalistas, uma vez que esse resultado é esperado devido aos pequenos fragmentos presentes e que esses hábitos alimentares, conforme discutido por Willis, (1979) atuam como um tipo de efeito-tampão contra essas oscilações no suprimento alimentar, o que faz ocorrer uma restrição da ocorrência de nectarívoros e frugívoros, além de espécies de insetívoros mais especializados.

Os ambientalistas vêm agindo na preservação das espécies. Os aspectos envolvendo o comportamento das aves, comprova ainda mais a exploração avícola moderna perante a situação ambiental em que as aves estão sujeitas. A ciência que é relacionada com o comportamento dos animais é chamada de etologia. Ela vem aumentando sua importância devido a sua relação com a Ecologia; além de que, o comportamento é um fenômeno que envolve uma complexidade significativa, pois envolve indivíduos tanto em grupos quanto individualmente, e é controlada por mecanismos hormonais e neurobiológicos. 0 comportamento das aves dentro de uma população, destaca-se os hábitos que se modificam desde a criação confinada, semi-confinada ou totalmente livre. 0 comportamento animal pode ser entendido como a relação entre o organismo vivo e o exterior (MANNING, 1972; MENCH, 1992, GRAVES, 1982)

Segundo Campos, (2000) o comportamento das aves envolve a proteção das penas - glândulas uropigianas - espaço em si, banhar, esponjar, ciscar, dentro outros pontos. Vale a pena ressaltar que alguns aspectos referentes ao comportamento das aves mudam quando essas estão confinadas, principalmente a utilização da glândula de uropígio, que não desenvolvem mais a função de lubrificar as penas, já que não são mais utilizadas, logo, a tendência é atrofiar-se se a ave não sofrer nenhuma mudança relacionada a alojamento. Uma questão que vale ser ressaltada é sobre a moela, que inicialmente é uma musculatura dura, que é capaz de moer os grãos que são ingeridos pelas aves, assim, auxiliando no processo de digestão, com isso, se a ave recebe apenas uma ração farelada desde os primeiros dias de vida, esta musculatura se transforma em uma musculatura flácida, já que não é mais utilizada. Uma mudança no comportamento que vale a pena ser ressaltada é a questão de lamber as penas, preferencialmente as da cauda, o sexo não interferindo nessa ação já que ambos fazem esse processo. Com a afirmação é possível concluir que um pássaro que vive fora de seu habitat natural está submetido a variados processos de mudança em sua forma de vida.

Geralmente o comportamento das aves são referentes ao meio em que vivem, dando respostas aos estímulos do ambiente, tendo um repertório sensorial que ajuda na captação de informações do meio para que assim ocorra uma reação para cada situação. Logo, o que a ave enxerga e ouve interfere para a reação (LUDTKE et al., 2010).

As aves saem do ambiente natural e migram para o urbano, sendo um dos motivos, pela confusão de habitats, não percebendo quando saem de um ambiente e entram em outro. Há estudos que comprovam que Gubernetes yetapa, popularmente conhecida como tesoura-do-brejo não apresenta um comportamento que é totalmente dependente de áreas que apresentam brejo para a sua alimentação, mas é dependente desse espaço para construir ninhos e se abrigar no período da noite, acreditando-se ser esta a principal vegetação que a espécie ocupa. Por isso, a espécie pode ser afetada devido a ações humanas que descaracterizem as áreas de brejos, como por exemplo, aterros, desvio de cursos d'água, desmatamento de matas ciliares e as drenagens (BELMONTE-LOPES, 2008).

O arapaçu-de-garganta-branca, cientificamente conhecido como Xiphocolaptes albicollis (Vieillot, 1818), é o principal representante da família dos Dendrocolaptidae que são encontrados na Floresta Atlântica do sudeste do Brasil. 0 estudo de Parrini \& Raposo, (2012) teve como principal objetivo investigar o forrageamento dessa espécie nas florestas do Parque Nacional da Serra dos Órgãos e de Itatiaia, onde as observações ocorreram entre os anos de 2000 e 2010. Nessas buscar foram registrados 78 indivíduos e 156 eventos de exploração de substratos, onde, aproximadamente $49 \%$ foram direcionados a bromélia. A espécie explorou constantemente as bromélias grandes e médias, fazendo uso de variados comportamentos para capturar suas presas em quatro diferentes tipos de substratos das bromélias. 0 súber dos troncos também foi explorado pela espécie, que demonstra interesse por material vegetal que está em decomposição. 
Segundo o Guia de Aves da mata atlântica Paulista a popularmente conhecida como alma-de-gato, a Piaya cayana, geralmente é grande e vistosa e vive em ambientes arborizados, sendo este até as cidades. Percorre com rapidez a copa das árvores, porém está sempre sozinha. Seu voo é intercalado com algumas batidas de asas e calda aberta. Ele se alimenta basicamente de taturanas e lagartas. Geralmente é mais avistado com frequência em sedes de unidades de conservação. Ela pode ser encontrada nas cidades, nas seguintes localidades: Santo Dias, Anhanguera, Carmo, Burle Marx, Toronto, Parques Alfredo Volpi Ibirapuera, , Fazenda Capivari (SABESP) , Previdência, , Guarapiranga. Em outras áreas verdes como Parque Estadual da Serra do Mar-Núcleo Curucutue e Bairro Jardim Herculano, e geralmente vivem de casais tendo a grande habilidade de descer as copas planando (SICK, 1997; HOFLING \& CAMARGO, 1993).

Segundo Yarranton \& Morrison, (1974) a técnica de nucleação nada mais é do que a capacidade de melhora nas condições ambientais tendo como objetivo resgatar a funcionalidade local, além de atrair a diversidade, assim, permitindo a ampliação na probabilidade de ocupação de diferenças espécies na área que foi degradada. A nucleação é uma básica para diminuir a ações feitas pelo homem, tendo como principal objetivo a restauração das comunidades se tornando um princípio de sucessão no processo de colonização das áreas que estão sendo reconstituídas. Para uma maior diversidade e para que se estabilize o mais rápido possível entrando minimamente as taxas energéticas, nas áreas degradadas, as técnicas de nucleação que serão empregadas nestas áreas são avaliadas para que sejam colocadas em práticas da melhor forma (REIS et al., 2003).

\section{CONCLUSÃO}

A partir das informações levantadas neste trabalho, foi possível concluir que o aumento das áreas urbanas modifica o comportamento da avifauna no cenário brasileiro, uma vez que o avanço populacional implica na mudança do ambiente para as mais diversas espécies ambientais, seja pela diminuição das áreas de florestamento que antes eram utilizadas pelas espécies, além de apresentarem condições básicas para a sua sobrevivência.

Ao olharmos fatos atuais, em que ambientes vêm sofrendo bruscas mudanças, as pesquisas envolvendo esta temática vem aumentando, sendo necessário incluir na discussão o comportamento, alimentação e reprodução da avifauna, para que assim, uma mudança nesse quadro possa ser implementada.

0 trabalho em questão, reforça a necessidade de uma maior discussão já que se a população atual não for educada, o meio ambiente sofrerá drásticas mudanças, e daqui alguns anos o planeta se tornará um local inabitável, uma vez que todas as áreas naturais serão destruídas, incluindo o habitat de vários animais, aves, microfauna, entre outros. Frente a isso, é possível perceber a importância da educação ambiental, onde o ser humano deve aprender a viver em harmonia com o meio ambiente, percebendo que ele não é o dono, mas sim que faz parte deste.

\section{REFERÊNCIAS}

[1] AUSDEN, M. 2004. Habitat management. In: Sutherland, W. J.; Newton, I. \& Green, R. E. (eds). Bird ecology and conservation - A handbook of techniques. Techniques in Ecology \& Conservation Series, Oxford University Press, Oxford, USA, p.329-369.

[2] BELMONTE-LOPES, R. 2008. Biologia E Comportamento Da Tesoura-Do-Brejo (Gubernetes yetapa,Aves: Tyrannidae) Em Uma Área Aberta Antropizada. Monografia (Ciências Biológicas). Universidade Federal do Paraná. 25 p.

[3] BORLETO, S.; SILVA FILHO, D. F.; LIMA, A. M. L. P. 2006. Prioridades de manejo para a arborização viária da estância de águas de São Pedro-SP, por setores. Revista da sociedade brasileira de arborização urbana, v. 1, n.1.

[4] BRUN, F. G. K.; LINK, D.; BRUN, E. J. 2007. O emprego da arborização na manutenção da biodiversidade de fauna em áreas urbanas. Revista da sociedade brasileira de arborização urbana, v. 2, $\mathrm{n}^{\circ} 1$.

[5] CAMPOS, E. J. 2000. O Comportamento das Aves. Rev. Bras. Cienc. Avic. [online]. Vol.2, n.2, pp. 93113.

[6] FUSCALDI, R. G. \& LOURES-RIBEIRO, A. 2008. A avifauna de uma área urbana do município de Ipatinga, Minas Gerais, Brasil. Biotemas, 21 (3): 125-133. 
[7] FRANCHIN, A. G. 2009. Avifauna em áreas urbanas brasileiras, com ênfase em cidades do Triângulo Mineiro/Alto Paranaíba. 160 p. Tese (Doutorado em Ecologia e Conservação de Recursos Naturais). Universidade Federal de Uberlândia.

[8] FRANCHIN, A.G. \& Marçal Júnior, 0. 2002. A riqueza da avifauna urbana em praças de Uberlândia (MG). Revista Eletrônica Horizonte Científico, 1 (1):1-20.

[9] GUIA DE AVES MATA ATLÂNTICA PAULISTA, 2010 - Serra do Mar e Serra de Paranapiacaba / Coordenação Geral: Luciana Lopes Simões WWF Brasil, São Paulo, 1a edição.

[10] GRAVES, H. B. 1982. Behavioral responses of poultry (chickens) to management systems. In: Proceedings of the Symposium of Management of Food Producing Animals. Purdue University, West Lafayiette, IN. 2: 122-138.

[11] GUIMARÃES, M. 2006. Há mais aves nos grandes centros urbanos hoje? Cienc. Cult., v.58, n.2, São Paulo, Apr./June. Disponível em: < http://cienciaecultura.bvs.br/pdf/cic/v58n2/a07v58n2.pdf > Acesso em: 10/08/2015.

[12] Hofling, E; Camargo, H. F.A. 1993. Aves no Campus. Instituto de Biociências da Universidade de São Paulo, São Paulo, 126 p.

[13] JENNI, L. \& KÉRY, M. 2003. Timing of autumn bird migration under climate change: advances in long-distance migrants, delays in short-distance migrants. Proc Biol Sci. Jul 22;270(1523):1467-71.

[14] LOMBARDO, M.A. 1990. Vegetação e Clima. In: ENCONTRO NACIONAL SOBRE ARBORIZAÇÃO URBANA, 1990, Curitiba, PR. Anais ... Curitiba: FUPEF, 368 p. p. 1-13.

[15] LUDTKE, C. B.; CIOCCA, J. R.; DANDIN, T.; BARBALHO, P. C.; VILELA, J. A. 2010. Abate humanitário de aves. Rio de Janeiro : WSPA.

[16] MANNING, A. 1972. An Introduction to Animal Behaviour. Addiosn-Wesley, Reding, M. A. p.329.

[17] MARZLUFF, J.M. 2001. Worldwide urbanizati on and its effects on birds. p.19-47. In: Marsluff, J.M., Bowman, R., Donnelly, R. (ed). Avian ecology and conservation in an urbanizing world. Kluwer Academic Publishers, Boston.

[18] MELLES, S.; GLENN, S.; MARTIN, K. 2003. Urban bird diversity and landscape complexity: Speciesenvironment associations along a multiscale habitat gradient. Conservation Ecology, 7 (1): 5.

[19] MENCH, J.A. 1992. Applied Ethology and poultry production. Poultry Science. 71:631-633.

[20] MENDONÇA-LIMA, A. M.; FONTANA, C. S. 2000. Composição, freqüência e aspectos biológicos da avifauna no Porto Alegre Country Clube, Rio Grande do Sul. Ararajuba, 8 (1): 1-8.

[21] PARRINI, R.; RAPOSO, M. A. 2012. Comportamento alimentar de Xiphocolaptes albicollis. Bol. Mus. Biol. Mello Leitão (N. Sér.) 29.

[22] REIS, A.; BECHARA, F.C.; ESPÍNDOLA, M.B.; VIEIRA, N.K.; SOUZA, L.L. 2003. Restauração de áreas degradadas: a nucleação como base para incrementar os processos sucessionais. Natureza e Conservação. v.1, n.1, p.28-36.

[23] RIBEIRO, L. B. \& SILVA, M. G. 2007. O comércio ilegal põe em risco a diversidade das aves no Brasil. Cienc. Cult., v.59, n.4 São Paulo. Disponível em: < http://cienciaecultura.bvs.br/pdf/cic/v59n4/a02v59n4.pdf> Acesso em: 10/08/2015.

[24] SCHERER, J. F. M.; SCHERER, A. L.;PETRY, M. V.; TEIXEIRA, É. C. 2006. Estudo da avifauna associada à área úmida situada no Parque Mascarenhas de Moraes, zona urbana de Porto Alegre (RS). Revista Biotemas, v.19, n.1.

[25] SICK, H. 1997. Ornitologia Brasileira. Editora Nova Fronteira. Rio de Janeiro, 912 p.

[26] SOUZA, F. L. 1995. Avifauna da cidade de Ribeirão Preto, estado de São Paulo. Biotemas, 8 (8): 100-109.

[27] VILLANUEVA, R. E. \& SILVA, M. 1995. Status de conservação da avifauna da região do Campeche, Ilha de Santa Catarina, SC. Biotemas, Florianópolis, v. 8, n. 1, p. 72-80.

[28] WILLIS, E.O. \& ONIKI, Y. 1987. Invasion of deforested regions of São Paulo state by the picazuro pigeon, Columba picazuro Temminck, 1813. Ciência e Cultura, 39 (11): 1064-1065. 
[29] WILLIS, E. O. 1979. The composition of avian communities in remanescent woodlots in Southern Brazil. Papéis Avulsos de Zoologia, São Paulo, v. 33, n. 1, p. 1-25, jul.

[30] YARRANTON, G.A.; MORRISON. R. G. 1974. Spatial ynamics of a primary succession: nucleation. Journal of Ecology 62(2): 417-428. 


\section{Capítulo 8}

A análise da arborização urbana como perspectiva de desenvolvimento da sustentabilidade na Subprefeitura do Butantã, no município de São Paulo, SP

Amanda Lombardo Fruehauf

Paulo Renato Mesquita Pellegrino

Magda Adelaide Lombardo

Resumo: 0 crescimento das cidades está associado à especulação imobiliária e a mudança da população das áreas rurais para as áreas urbanas. Assim, deve-se criar nas cidades espaços com arborização, para minimizar os efeitos maléficos causados pela intensa urbanização, como surgimento da ilha de calor urbana, superfícies impermeáveis, poluição do ar, inundações, falta de espaços para lazer. Deve-se buscar a sustentabilidade desses espaços que são utilizados pela população. 0 trabalho visou analisar e quantificar por meio de geotecnologias e quantificar, a arborização urbana da Subprefeitura do Butantã e sua distribuição socioespacial. 0 trabalho teve como área de estudo a Subprefeitura do Butantã, localizado na zona sudoeste do Município de São Paulo, SP. Foi utilizado o software Quantum GIS para mapeamento e quantificação da arborização urbana viária da Subprefeitura do Butantã, com base no site do GeoSampa do ano de 2013, onde verificou-se a distribuição de 49.216 árvores e a desigualdade da distribuição espacial na Subprefeitura do Butantã, SP que engloba os cinco distritos: Butantã, Morumbi, Raposo Tavares, Rio Pequeno e Vila Sônia.

Palavras-chave: arborização urbana, geotecnologias, sustentabilidade. 


\section{INTRODUÇÃO}

O aumento dos espaços urbanos juntamente com o aumento populacional no Brasil se intensificou-se a partir de 1950. Com essa expansão, surgiram-se grandes cidades e regiões metropolitanas.

Neste contexto, o crescimento das cidades está associado à especulação imobiliária e a mudança da população das áreas rurais para as áreas urbanas. Desde 1960, no Brasil, houve uma intensa urbanização, com processo de metropolização e caracteriza-se pelo uso e ocupação da terra sem planejamento até no interior, nas pequenas e médias cidades. Devido à intensa urbanização com o aumento de áreas edificadas e asfalto, as cidades apresentam alteração climática com variação de temperatura e umidade relativa (LOMBARDO, 1985).

Desta forma, deve-se criar nas cidades espaços com arborização, para minimizar os efeitos maléficos causados pela intensa urbanização, como alteração do microclima (surgimento da ilha de calor urbana), superfícies impermeáveis, poluição do ar, inundações, falta de espaços para lazer. Buscando assim a sustentabilidade desses espaços que são utilizados pela população.

Na busca de ambientes físicos saudáveis, é importante incluir a arborização urbana que deve apresentar as espécies vegetais adequadas para compor os espaços públicos como parques, ruas, avenidas, jardins e praças. Estas árvores devem atuar sobre o conforto humano propiciando qualidade de vida para a população (WESTPHAL, 2000).

0 trabalho visou analisar e quantificar por meio de geotecnologias e busca de dados, a arborização urbana da Subprefeitura do Butantã, como esta, é distribuída entre os distritos que a compõem e desta forma avaliar como a distribuição de árvore poderia ser mais igualitária e assim promover a sustentabilidade.

\section{FUNDAMENTAÇÃO TEÓRICA}

\subsection{ARBORIZAÇ̃̃O URBANA}

Nas cidades, onde há impermeabilização do solo juntamente com materiais de elevada amplitude térmica, uma solução para resolver estes problemas é implementar a vegetação nas áreas urbanas, com destaque as árvores, como arborização de vias públicas, praças e áreas de preservação (BAKER et al., 2003).

A arborização urbana assume um papel fundamental para a promoção de qualidade de vida. Vêm crescendo a preocupação da população com os benefícios que podem surgir com um meio ambiente saudável.

No conforto humano, a arborização urbana atua, proporcionando sombra para pedestres e veículos, redução da poluição sonora, melhoria da qualidade do ar, redução da amplitude térmica, abrigo para pássarose equilíbrio estético, que ameniza a diferença entre a escala humana e outros componentes arquitetônicos comoprédios, muros e grandes avenidas (SILVA FILHO; PIZZETTA; ALMEIDA, 2002).

Deve-se atentar para o planejamento e espécies utilizadas na arborização urbana. Geralmente, nas cidades usam-se poucas espécies arbóreas, de forma fragmentada, o que não contribui para a biodiversidade da flora e fauna que poderia ser abrigadas pela fonte de alimento e assim, poucas espécies da fauna conseguem sobreviver na área urbana (BRUN; LINK; BRUN, 2007).

Assim, nas áreas urbanas a arborização exerce importante função, gerando benefícios ambientais e sociais que contribuem para a qualidade de vida dos habitantes. Sendo que a arborização urbana deve ser vista como importante elemento de reestruturação dos espaços urbanos, aproximando as condições ambientais normais com o meio urbano (RIBEIRO, 2009).

\subsection{GEOTECNOLOGIAS}

As geotecnologias contribuem para a elaboração de estudos de áreas com questões ambientais a serem resolvidas, gerando mapas do ambiente analisado a fim de se identificar a realidade que se encontra e pensar em soluções sustentáveis para estes espaços.

Segundo Leite e Rosa (2006), as geotecnologias auxiliam no planejamento da área de estudo. Essa tecnologia fornece contribuição para a gestão urbana e entendimento da paisagem. A alta resolução do sensoriamento remoto permite o mapeamento em detalhe, contribuindo para os estudos das cidades. 
Deste modo, as geotecnologias abrangem o levantamento de dados espaciais, não espaciais, modelos, análises e tratamento de dados. Destacando o Sistema de Informação Geográfica (SIG) como incorporação de várias tecnologias em um todo (FERREIRA, 2019).

O SIG tem é uma ferramenta possibilita mapear áreas e criar a partir disto um banco de dados sobre a área de estudo (FRUEHAUF, 2016). 0 uso deste sistema é fundamental ao estudo de mapeamento que visam utilizar os dados de forma digital (HAMADA; GONÇALVES, 2007).

Dentro do SIG, pode-se utilizar o software Quantum GIS (QGIS) para elaborar mapas. O QGIS foi criado pela OpenSourc e Geospatial Foundation (OSGeo, 2020), vem sendo disponibilizado em código aberto e gratuito na internet desde 2009, para apoiar e construir programas geo-espaciais.

\subsection{SUSTENTABILIDADE}

No tema de sustentabilidade, se encontra o conceito de resiliência que abrange conjunto de informações importantes para que as cidades superem os limites da perspectiva antropológica, que envolve o desenvolvimento urbano e assim tornar os espaços mais ecológicos (LOTUFO, 2016).

O mesmo autor destaca a importância de introduzir a ecologia no desenho das cidades, para garantir a sustentabilidade, assegurando o futuro do planeta, das próximas gerações. Assim é necessária a reintegração entre natureza e civilização na busca da resiliência ecológica.

Desta forma a sustentabilidade urbana está ligada à qualidade da arborização urbana na busca de uma cidade ecológica e sustentável (DE OLIVEIRA; ROSIN, 2013).

Os serviços ecossistêmicos, como a arborização, são impulsionadores da sustentabilidade e resiliência urbana, que representa o quanto um sistema pode suportar de alterações, sem mudar de estado. Na busca da resiliência, há diferentes maneiras de testar planos e projetos que associam espacialmente o urbano com as funções sociais e biofísicas (AHERN, 2011).

Segundo Keesstraet al. (2018), para se alcanças a sustentabilidade deve-se unir soluções para o uso da terra e a paisagem, promovendo os serviços ecossistêmicos com a concepção da conectividade.

\section{METODOLOGIA}

0 trabalho foi desenvolvido na Subprefeitura do Butantã, localizado na zona sudoeste do município de São Paulo, SP (Figura 1). 0 município de São Paulo possui 11.253 .503 habitantes e uma área de $1521 \mathrm{~km}^{2}$, com densidade demográfica de 7898, 2 hab $/ \mathrm{km}^{2}$ (IBGE, 2010). A subprefeitura de Butantã compreende cinco distritos heterogêneos: Butantã, Morumbi, Vila Sônia, Raposo Tavares e Rio Pequeno, todos juntos representam uma área total de 56, $10 \mathrm{~km}^{2}$, com uma população de 428.217 com uma densidade demográfica de 7.633 hab $/ \mathrm{km}^{2}$ (PREFEITURA DE SÃO PAULO, 2017).

Foi utilizado o software Quantum GIS (QGIS), o surgimento do QGIS juntamente com o Google Earth, aproximou as pessoas para o conhecimento das geotecnologias aplicadas no geoprocessamento (BOSSLE, 2015).

Também foi feita uma busca da quantificação da arborização urbana viária da Subprefeitura do Butantã, no site do GeoSampa do ano de 2013. A fim de verificar como estas estavam distribuídas entre os distritos que a compõem.

A plataforma GeoSampa, reúne mais de 150 tipos de dados georreferenciados sobre a cidade de São Paulo, que abrange zoneamento, equipamentos urbanos, rede de transporte público, mapas geotécnicos e dados sobre a população entre outros, incluindo dados do parcelamento do solo. 0 portal está alinhado à Lei de Acesso à Informação - LAI5, disponibilizando dados para download, de forma que podem ser consultados e utilizados para pesquisas e diversos fins em que o usuário desejar (DE LIMA; DAMIAO; DE OLIVEIRA, 2017).

Segundo Bonametti (2001), a arborização urbana que abrange toda cobertura vegetal, visa evitar a ocorrência da ilha de calor, diminuição da poluição e ainda tem seu papel estético na paisagem.

A Ilha de Calor (IC) é o fenômeno onde devido à urbanização o clima térmico é modificado, sendo mais quente do que as áreas circundantes não urbanizadas, principalmente à noite (VOOGT; OKE, 2003). 
Desta forma visou-se analisar a distribuição espacial da arborização urbana entre os distritos da área de estudo, de forma a apontar que a política pública deve se atentar para o planejamento urbano da sua arborização, para que seja bem distribuída e promova a sustentabilidade.

O planejamento urbano contribui para a eficácia da arborização. Ou seja, sem esta pode ocorrer plantios irregulares, sem conhecimento técnico das espécies e que não seja, compatível com o planejamento anterior e assim, não contribui para a qualidade de vida da população (ALMEIDA; RONDON NETO, 2010).

Figura 1: Localização da área de estudo.

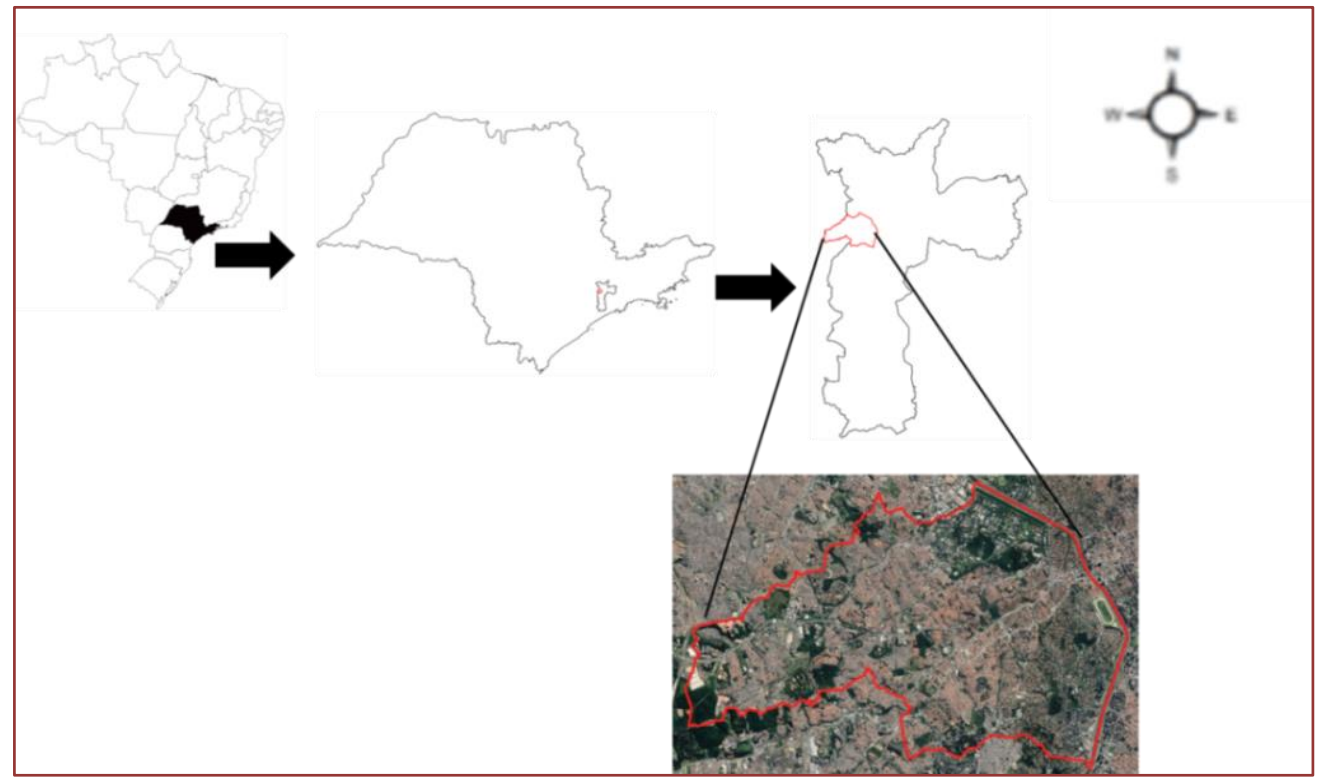

Fonte: Amanda Lombardo Fruehauf (2019).

\section{RESULTADOS}

Com base no mapa da área de estudo, realizou-se o mapa de arborização urbana de 2013. Para ilustrar a localização dos distintos distritos que compõem a Subprefeitura do Butantã, buscou-se na literatura a figura 2 .

Figura 2: Localização da Subprefeitura do Butantã em relação ao município de São Paulo, SP, com os cinco distritos.

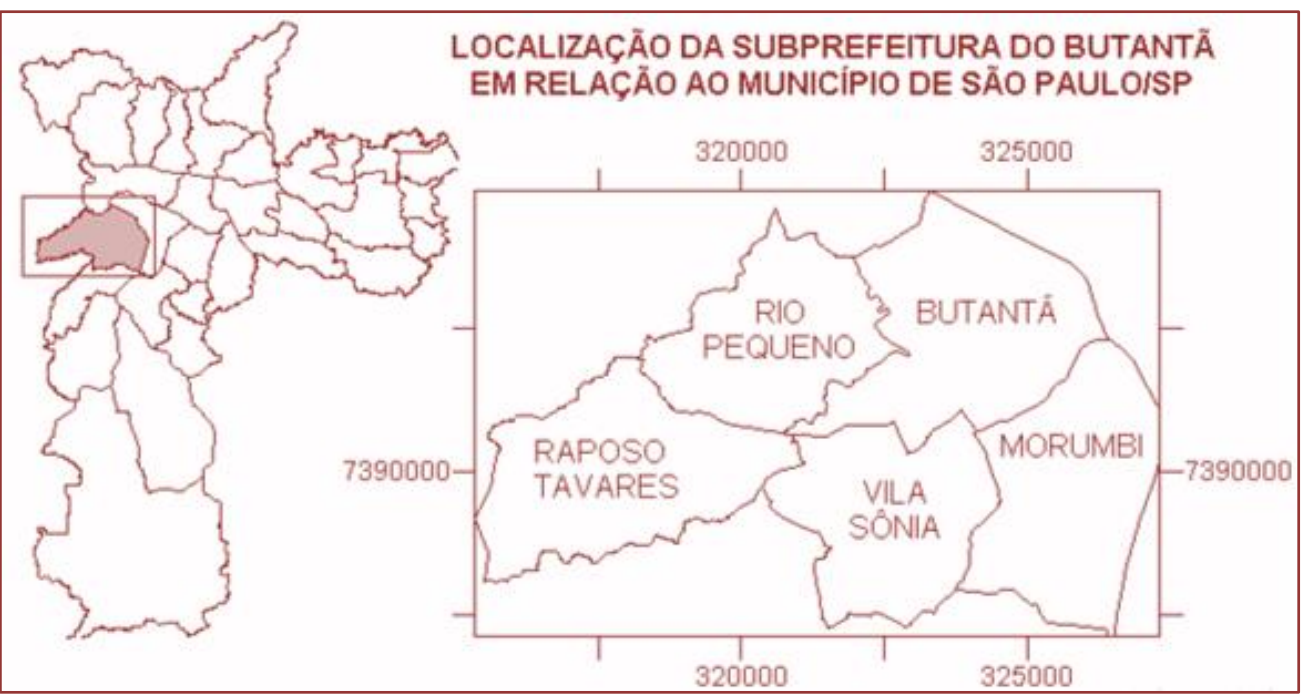

Fonte: Morato; Kawakubo,2007. 
A desigualdade entre os distritos, é apresentada na Pesquisa e análise de aplicação de instrumentos em planejamento urbano ambiental no Município de São Paulo, realizada pelo Laboratório de Habitação e Assentamentos Humanos Faculdade de Arquitetura e Urbanismo da USP (LabHab/FAUUSP, 2006), há uma ocupação heterogênea interna da subprefeitura do Butantã. Para verificar esta heterogeneidade é importante caracterizar os cinco distritos da área de estudo. 0 distrito Raposo Tavares possui intensa industrialização, atividades de atendimento para a população de classe mais baixa. 0 distrito Rio Pequeno tem as mesmas características, apenas tem menos quantidade de áreas industriais e comércio. Os distritos Vila Sônia e Butantã predominam bairros de classe média e alta, principalmente no Butantã que também possui maiores infraestruturas como a presença da cidade universitária (USP), o Jóquei Clube e o Instituto Butantã. Por último o distrito do Morumbi, apresenta os bairros de alta classe de renda, com alta verticalização de alto custo.

0 mapa de arborização urbana (Figura 3) foi elaborado no QGIS, com a busca de dados de arborização viária no site do GeoSampa, com base em imagem de satélite de 2013, obtendo 49.216 árvores, demonstrando a desigualdade da distribuição espacial na Subprefeitura do Butantã, SP que engloba os cinco distritos: Butantã, Morumbi, Raposo Tavares, Rio Pequeno e Vila Sônia.

Figura 3: Mapa de arborização urbana da Subprefeitura do Butantã, 2013.

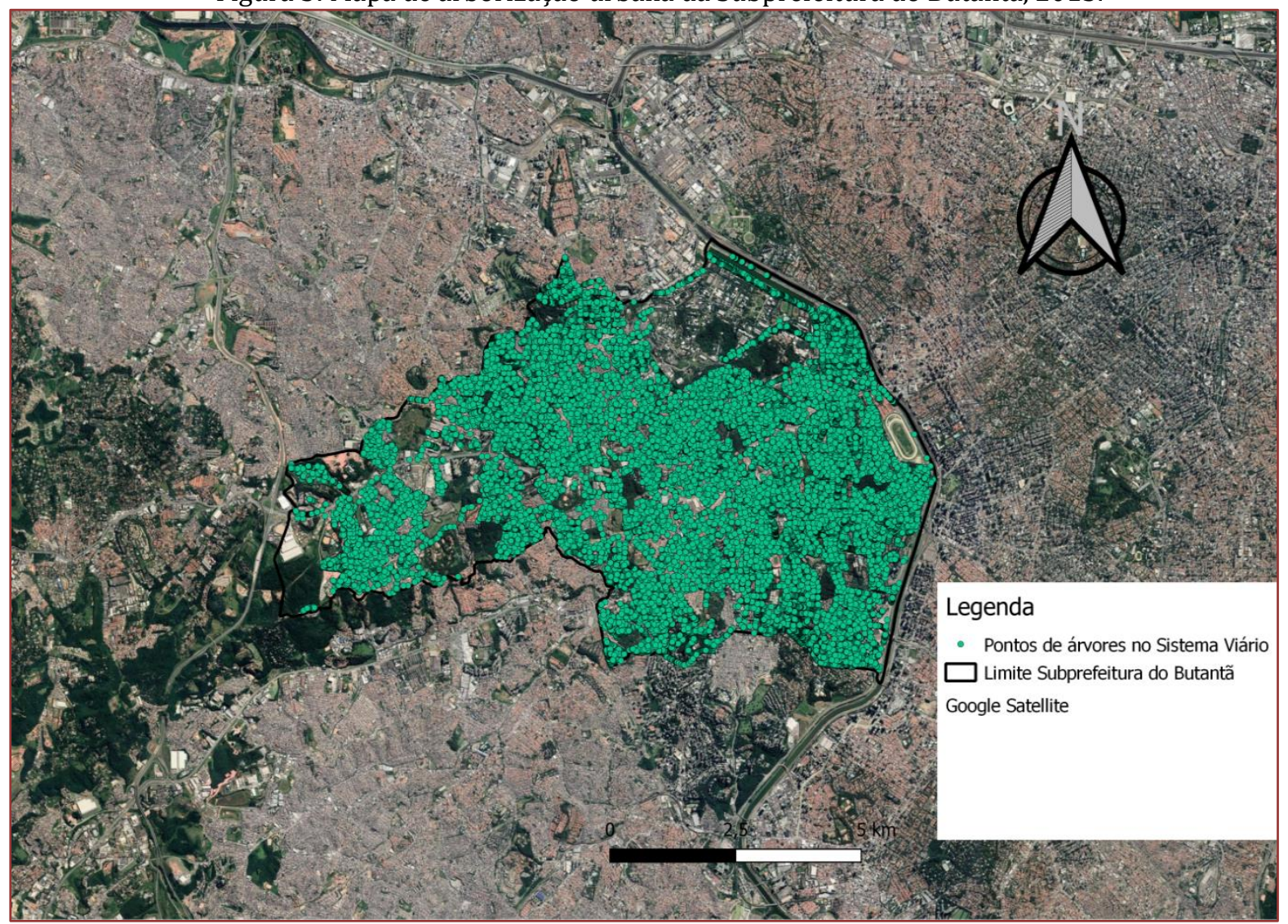

Fonte: Geosampa (2013).

Segundo Morato e Kawakubo (2007), que analisaram a vegetação na Subprefeitura do Butantã, destacouse a vegetação com maior desigualdade de distribuição entre os distritos.

Nesta pesquisa, com o levantamento da arborização urbana da Subprefeitura do Butantã, verificou-se como esta é distribuída nos cinco distritos, demonstrando que o distrito com maior poder aquisitivo, no caso o Morumbi, apresenta maior arborização viária. Os distritos Vila Sônia e Butantã possuem razoável arborização viária, com bairros de classe média a alta, Butantã se destaca com maior vegetação, pois têm a cidade Universitária (USP) que é rodeada de árvores e outras infraestruturas como o Jóquei Clube e Instituto Butantã. E os distritos Raposo Tavares e Rio Pequeno, que possuem o menor poder aquisitivo, são os que mais carecem de quantidade de arborização urbana. 


\section{CONCLUSÕES}

0 mapa de arborização urbana demonstrou como estão distribuídas as árvores na paisagem da área de estudo, mostrando a desigualdade socioespacial. Assim, este trabalho pode buscar soluções para incrementar a arborização urbana viária.

Destaca-se que a arborização urbana apresenta diversos benefícios para melhoria das condições climáticas da cidade, como mitigação da ilha de calor, diminuição da poluição do ar, redução de enchentes, lazer, sendo positivo para a saúde física e mental. Proporcionando para os habitantes uma melhoria de qualidade de vida.

Assim, verifica-se a carência de políticas públicas no âmbito ambiental, principalmente no planejamento e implantação de arborização urbana, de forma a ter uma arborização mais igualitária espacialmente na busca da qualidade ambiental e de vida e consequentemente na promoção da sustentabilidade.

\section{AGRADECIMENTOS}

O presente trabalho foi realizado com apoio da Coordenação de Aperfeiçoamento de Pessoal de Nível Superior - Brasil (CAPES) - Código de Financiamento 001.

\section{REFERÊNCIAS}

[1] AHERN, Jack. From fail-safe to safe-to-fail: Sustainability and resilience in te new urban world. Landscape and Urban Planning (100):341-343. doi: 10.1016/j.landurbplan.2011.02.021, 2011.

[2] ALMEIDA, D. N. de; RONDON NETO, R. M. Análise da arborização urbana de duas cidades da região norte do estado de Mato Grosso. Revista Árvore, v. 34, n. 5, p. 899-906, 2010.

[3] BAKER, L.A.et al.Urbanization and warming of Phoenix (Arizona, USA): impacts, feedbacks and mitigation. Urbanecosystems, v.6, p.183-203, 2003.

[4] BONAMETTI, J. H. Arborização Urbana. Curitiba: Terra e Cultura, n. 36, 2001. Disponível em:<http://web.unifil.br/docs/revista_eletronica/terra_cultura/36/Terra\%20e\%20Cultura_36-6.pdf> Acesso em: 12 set. 2020 .

[5] BOSSLE, R. C. QGIS e geoprocessamento na prática. São José dos Pinhais, PA: Edição do autor, Editora Íthala, 232p., 2015.

[6] BRUN, FláviaGizeleKönig; LINK, Dionísio; BRUN, Eleandro José.0 emprego da arborização na manutenção da biodiversidade de fauna em áreas urbanas. Revista da Sociedade Brasileira de Arborização Urbana, v. 2, n. 1, p. 117 $127,2007$.

[7] DE LIMA, V.L; DAMIAO, S.R.R; DE OLIVEIRA, M.C. Banco de dados geográficos e licenciamento: a experiência da Secretaria Municipal de Licenciamento de São Paulo, XVII ENAMPUR, São Paulo, 2017.

[8] DE OLIVEIRA, Marcinéia Vaz Moraes; ROSIN, Jeane Aparecida Rombi De Godoy. Arborização dos espaços públicos: uma contribuição à sustentabilidade urbana. Revista Nacional de Gerenciamento de Cidades, v. 1, n. 3, 2013.

[9] HAMADA, E.; GONÇALVES, R.R.V. Introdução ao geoprocessamento: princípios básicos e aplicaçãoJaguariúna: Embrapa Meio Ambiente, p.52, 2007.

[10] IBGE. Censo 2010. Disponível em: <https://censo2010.ibge.gov.br/sinopse/index.php?uf=35>. Acesso em: 10 set. 2020

[11] FERREIRA, A. S. Uso de geoprocessamento e geotecnologias no mapeamento de áreas de vulnerabilidade à inundação no perímetro urbano do município de Humaitá, Sudoeste da Amazônia. Trabalho de Conclusão de Curso, Universidade Federal do Amazonas - UFAM, Humaitá, Amazonas, 2019.

[12] FRUEHAUF, A.L. 0 uso da geotecnologia na análise de áreas irrigadas com pivô central na bacia hidrográfica do córrego da conserva em Vargem Grande do Sul, SP - um enfoque agroecológico. Trabalho de Conclusão de Curso (TCC) - Universidade Federal de São Carlos, Centro de Ciências Agrárias, Araras, São Paulo, 33p. 2016.

[13] KEESSTRA, S. et al. The superior effect of nature based solutions in land management for enhancing ecosystem services. Science ofthe Total Environment, v. 610, p. 997-1009, 2018.

[14] LEITE, M. E.; ROSA, R. Geografia e geotecnologias no estudo urbano. Caminhos de Geografia, v. 7, n. $17,2006$.

[15] LOMBARDO, M.A. Ilha de Calor nas Metrópoles: O exemplo de São Paulo. São Paulo,244 p. Ed. Hucitec, 1985. 
[16] LOTUFO, José Otávio. Projeto sustentável: resiliência urbana para o Bairro da Pompéia. 2016. Tese de Doutorado. Universidade de São Paulo. Disponível em:<https://www.teses.usp.br/teses/disponiveis/16/16138/tde19122016-153348/en.php>. Acessoem: 15 set. 2020.

[17] MORATO, R. G; KAWAKUBO, F. S. Análise espacial da desigualdade ambiental na subprefeitura de Butantã, São Paulo - SP. Revista brasileira de geografia médica e da saúde, p.66-73, 2007.

[18] Open Source Geospatial Foundation (OSGeo). Disponívelem:<http://www.osgeo.org/home>. Acesso em: 10 set. 2020

[19] Portal da Prefeitura de São Paulo. 2017. Disponível em: <http://www.prefeitura.sp.gov.br/cidade/secretarias/regionais/subprefeituras/dados_demograficos/index.php?p=1 2758> Acesso em: 5 set. 2018.

[20] RIBEIRO, F. A. B. S. Arborização urbana em Uberlândia: percepção da população. Revista da Católica, v. 1, n. 1, p. 224-237, 2009.

[21] SILVA FILHO, D.F., PIZZETTA, P. U. C., ALMEIDA, J. B. S.A. Banco de dados relacional

[22] para cadastro, avaliação e manejo da arborização em vias públicas. Revista Árvore, v.26, n.5,p.629-642. 2002.

[23] VOOGT, J. A.; OKE, T. R. Thermal remote sensing of urban climates. Remote sensing of environment. 86.3: $370-384,2003$.

[24] WESTPHAL, M. F. O Movimento Cidades/Municípios Saudáveis: um compromisso com a qualidade de vida. Ciência e saúde coletiva, v.5, n.1, p.39-51, 2000. 


\section{Capítulo 9}

\section{Plástico verde obtido do bagaço da cana-de-açúcar: Aspectos econômicos e sociais ${ }^{1}$}

\section{Claudia Rebechi Yokota}

\section{Cristina Martinelli}

Simone Aparecida Rigobeli Vanalli

\section{Otávio Akira Sakai}

Stella Alonso Rocha

Resumo: A utilização do plástico verde tornou-se um diferencial mercadológico e uma forma de colaboração com o meio ambiente por ser proveniente de fontes renováveis e fazer a captura do gás carbônico da atmosfera ao longo da sua produção. 0 estudo consiste em um artigo de revisão visando a descrição de como o processo produtivo do plástico verde contribui para a sustentabilidade nos aspectos sociais e econômicos. Os resultados apontam o plástico verde como uma importante eco-inovação, com impactos positivos na economia da região onde houve uma expansão canavieira e repercussão positiva na comunidade com melhores condições de trabalho, qualificação e treinamento para os cortadores de cana.

Palavras-chave: cana-de-açúcar, plástico verde, polietileno verde, bioplástico, aspectos da sustentabilidade.

\footnotetext{
${ }^{1}$ Trabalho apresentado no II Sustentare - Seminário de Sustentabilidade da PUC-Campinas e V WIPIS - Workshop Internacional de Pesquisa em Indicadores de Sustentabilidade
} 


\section{INTRODUÇÃO}

A sustentabilidade socioambiental tem sido um assunto muito discutido nas últimas décadas, levantando questões importantes sobre os impactos das atividades econômicas no meio ambiente e na sociedade e como atingir o equilíbrio entre o desenvolvimento econômico e a preservação ambiental. Esse assunto é de interesse dos governos, instituições acadêmicas, sociedade, mas especialmente das empresas (RIPOLL et al., 2018).

O termo sustentabilidade foi difundido a partir de 1987 pela Comissão Mundial sobre Meio Ambiente e Desenvolvimento das Nações Unidas, definindo como desenvolvimento sustentável "aquele que atende às necessidades do presente sem comprometer a possibilidade das gerações futuras atenderem às suas próprias necessidades" (CMMAD, 1991, p. 46).

As organizações corporativas começaram a se preocupar com o meio ambiente e com soluções mais sustentáveis, não só devido às legislações, mas também em razão das pressões da sociedade, que está mais consciente e informada sobre os problemas ambientais e buscando por empresas com a mesma consciência ambiental e socialmente responsáveis (BRESCIANI et al., 2014; EISELE et al., 2015).

As indústrias químicas em busca de desenvolver produtos que causam menor impacto no meio ambiente, estão utilizando fontes renováveis para seus processos produtivos objetivando a preservação ambiental e o desenvolvimento sustentável (BRESCIANI et al., 2014).

Como o desenvolvimento do plástico verde ou polietileno verde, obtido do etanol da cana-de-açúcar, uma inovação para a substituição do plástico tradicional de origem fóssil por um plástico de origem renovável. A grande diferença entre os dois tipos de plásticos está relacionada aos termos de sustentabilidade, analisando a cadeia produtiva, o plástico verde faz a captura do gás carbônico da atmosfera, colaborando na redução dos gases causadores do efeito estufa.

Para o desenvolvimento do estudo foi utilizada a leitura exploratória, leitura seletiva com a escolha dos artigos com relevância para o tema deste trabalho, leitura analítica e por fim a leitura interpretativa para a escrita.

Assim, o presente artigo visa discutir e relacionar, a partir da literatura consultada, como o processo de produção do plástico verde colabora no processo de desenvolvimento sustentável sendo abordados com maior ênfase os aspectos econômicos e sociais.

\section{FUNDAMENTAÇÃO TEÓRICA}

\subsection{SUSTENTABILIDADE E O PLÁSTICO VERDE}

Uma empresa para atingir o patamar de "empresa sustentável" deve direcionar o seu foco, não apenas na dimensão econômica, que é a geração de lucros, é necessário também considerar as dimensões ambiental e social, reduzindo os impactos negativos que sua atividade gera para o meio ambiente e para a sociedade. Os aspectos sociais, ambientais e econômicos devem interagir conjuntamente para que o conceito de sustentabilidade seja atingido, o equilíbrio desses três aspectos, chamado de tripé da sustentabilidade ou triple bottom line, é que levará uma organização ao nível de empresa realmente sustentável (EISELE et al., 2015).

Segundo Oliveira et al., 2012, cada aspecto do triple bottom line tem seu propósito bem fundamentado: no plano econômico compreende em propiciar "empreendimentos que sejam viável e atraente aos investidores", no plano ambiental buscar a interação entre a produção e o meio ambiente, ao passo que o segundo não sofra com danos permanentes, pensando na matéria prima sustentável; no plano social considera importante consignar ações justas para "trabalhadores, parceiros e sociedade".

Para que o plástico verde seja considerado sustentável, ele deve atingir o equilíbrio entre os três aspectos do tripé da sustentabilidade. Para isso, devem ser analisados os impactos sociais, econômicos e ambientais que a produção do plástico verde causa na sociedade e no meio ambiente.

\subsection{A ECOEFICIÊNCIA E ECOINOVAÇÃO NOS PROCESSOS PLÁSTICOS}

A ecoeficiência é um indicador do quanto uma atividade econômica está de acordo com as normas e condutas para uma produção sustentável. Os primeiros autores a usar o termo ecoeficiência foram "Schaltegger e Sturm em 1990 (HAMILTOM et al., 2015). 
O World Business Council for Sustainable Development (WBCSD, 2006), define a ecoeficiência como um sistema de gestão para produzir mais com menos recursos.

Segundo a WBCSD (2006):

A ecoeficiência é alcançada através da oferta de bens e serviços a preços competitivos, que, por um lado, satisfaçam as necessidades humanas e contribuam para a qualidade de vida e, por outro, reduzam progressivamente o impacto ecológico e a intensidade de utilização de recursos ao longo do ciclo de vida, até atingirem um nível, que, pelo menos, respeite a capacidade de sustentação estimada para o planeta Terra.

Algumas organizações compreendem a ecoinovação como uma tática para ampliar os seus negócios, entendendo a necessidade de inovações dos processos produtivos. 0 objetivo é de amoldar-se ao um mercado mais voltado às questões ambientais. 0 termo ecoinovação foi trazido pela primeira vez por Fussler e James em seu livro Driving Eco-Innovation, publicado em 1996 (MAÇANEIRO; CUNHA, 2015).

No Brasil as pesquisas sobre ecoinovação são recentes, mas acredita-se que em decorrência da necessidade do mercado, novas pesquisas sobre o tema devem surgir (SILVA et al., 2018).

As indústrias estão utilizando novas tecnologias que possam transformar os produtos em ecoeficientes, desde a aquisição da matéria-prima até a disposição final ou reutilização (MASCARENHAS, 2020).

As empresas químicas fabricantes de plástico na busca de inovações, estão desenvolvendo tecnologias para a substituição do polímero tradicional, produzido a partir da nafta do petróleo, por um polímero de fonte renovável, como as biomassas de cana de açúcar, milho, beterraba e outros (BRESCIANI et al., 2014).

0 uso de novas tecnologias para a produção do plástico verde a partir de uma fonte renovável que é o etanol, extraído da cana-de-açúcar, torna o plástico verde um produto ecoeficiente, desde a aquisição da matéria-prima até a reutilização pelo processo de reciclagem, gerando diminuição no uso de recursos não renováveis e impacto ecológico.

\subsection{PLÁSTICO VERDE}

No desenvolvimento de tecnologias para a produção do plástico de fontes renováveis, o polietileno verde (PE) ou o plástico verde vem ganhando destaque (BRESCIANI et al., 2014).

No Brasil a Braskem, empresa petroquímica que desenvolveu a tecnologia para a produção do plástico verde a partir da cana-de-açúcar em substituição da nafta de petróleo, produz o mesmo com base $100 \%$ biológica, atestado por certificado internacional, ou seja, não tem matéria-prima fóssil, o que pode ser considerado um bioplástico (ANDRADE et al., 2009).

Segundo definição da European Bioplastics (2020), os bioplásticos não são apenas um único material, eles compõem uma família inteira de materiais com diferentes propriedades e aplicações. De acordo com os bioplásticos europeus, um material plástico é definido como bioplástico se for de base biológica, biodegradável ou apresentar as duas propriedades. 0 termo "base biológica" significa que o material ou produto é (parcialmente) derivado da biomassa (plantas), como é o caso do plástico verde produzido a partir da cana-de-açúcar, porém não é biodegradável.

O Brasil é um dos principais plantadores de cana do mundo, devido a suas características climáticas e as áreas de terra disponíveis para esse cultivo. De acordo com o UNICA (2020) o Brasil é o segundo maior produtor de etanol do mundo, ficando atrás dos Estados Unidos.

No Brasil a maior parte da produção do etanol é de cana-de-açúcar, no eua o etanol é produzido a partir do milho. Mas comparando as duas matérias-primas, a cana apresenta melhor desempenho, com menor custo de produção de etanol e produz três vezes mais etanol por área do que o milho, tornando o pe verde da cana uma opção mais viável (ANDREOLI; SOUZA, 2011).

0 processo de produção do plástico verde começa na plantação de cana. Após a colheita, a cana é enviada para as usinas, onde passa pela moagem, fermentação e destilação originando o etanol. 0 etanol é desidratado transformando-se em eteno verde. 0 eteno verde é polimerizado e convertido em polietileno verde em pó. Nas indústrias transformadoras os grânulos do polietileno verde é transformado em diversos produtos. (BOA VISTA et al., 2015). 
O plástico verde e o plástico tradicional possuem as mesmas propriedades físico-químicas, os dois tipos de plásticos são reciclados e possuem o mesmo tempo de decomposição.

Ao longo da sua cadeia produtiva, o plástico verde da cana-de-açúcar, faz a captura do gás carbônico (co2) da atmosfera, através da fotossíntese realizada pela cana, colaborando na redução dos gases causadores do efeito estufa. $O$ transporte de boa parte do etanol, dos fornecedores até a braskem, é feito pelas ferrovias, para colaborar na redução das emissões de $\mathrm{CO}_{2}$ (BARICHELLO et al., 2018).

Outra vantagem do plástico verde é que para transformá-lo em produto não é necessário equipamentos ou máquinas especiais, ele pode ser processado nas mesmas instalações do processamento do plástico tradicional, logo as indústrias de transformação não precisam de investimentos para utilizar o plástico verde (FARAH et al., 2016).

Como atrativo para os fabricantes de plásticos, utilizar o pe verde representa um valor agregado ao produto, pelas suas características de sustentabilidade. Mas para monitorar os produtos feitos com o pe verde a braskem criou o selo i'm green, que identifica o uso do pe verde nas embalagens (BARICHELLO et al., 2018).

O custo de produção do plástico verde é maior do que o plástico tradicional. Segundo mello et al. (2020) na produção do plástico de origem fóssil é possível produzir vários produtos a partir da nafta de petróleo (eteno, propeno, butadieno entre outros). No caso do plástico verde, o etanol só produz eteno e água, para produzir um quilo de eteno são necessário dois quilos de etanol.

Outro fator que influencia o custo é a variação do preço do etanol entre a safra (de abril a outubro) e entressafra (de novembro a março). Mas como a cadeia de produção do plástico verde é longa, essa diferença no custo entre os dois tipos de plástico é diluído entre as etapas, possibilitando o seu uso por diferentes setores da indústria (MELLO et al., 2020).

Em relação ao processo para substituir a matéria-prima fóssil pela matéria-prima renovável, apresentamse alguns aspectos a serem considerados:

a) Redução de $\mathrm{CO}_{2}$ no processo de produção: a Braskem realizou um estudo preliminar de ecoeficiência desse biopolímero em parceria com a Fundação Espaço Eco, com o objetivo de verificar os possíveis impactos ambientais de sua produção. A avaliação utilizou, como base, os dados da engenharia conceitual e revelou que, para cada tonelada de polipropileno verde produzida, são capturadas em torno de 2,3 toneladas de $\mathrm{CO}_{2}$ da atmosfera e fixadas. $\mathrm{O}$ estudo afirma que a resina verde tem as mesmas propriedades técnicas e de desempenho do polipropileno produzido a partir dos processos tradicionais (BRASKEM, 2010);

b) Substituição de combustíveis fósseis por renováveis impactando positivamente no meio ambiente: através de uma redução de emissões de gases do efeito estufa (GEE) muito maior do que a causada pelo uso do petróleo na indústria de plásticos. No setor petroquímico, têm-se buscado alternativas que envolvam menores impactos ambientais, utilizando fontes renováveis, plásticos biodegradáveis e bioplásticos, apesar de ser uma indústria que utiliza insumos de origem fóssil, não renovável. (FIDALGO et al., 2018);

c) Capacidade de cultivo de cana em terras degradadas evitando a concorrência com a agricultura de alimentos;

d) Variação do preço das matérias primas

\section{METODOLOGIA}

Esse estudo constitui uma revisão bibliográfica de caráter analítico em relação ao plástico verde obtido do bagaço da cana-de-açúcar: aspectos econômicos e sociais.

A busca bibliográfica foi realizada de junho a julho de 2020, nas bases de dados do portal de periódicos da Capes, Scientific Eletrônic Library Online (SCIELO), Google Scholar e site da empresa Braskem, abrangendo os artigos publicados entre 2010 a 2020. Os descritores utilizados nas pesquisas foram: plástico verde, polietileno verde, em português e inglês. Como resultados, foram encontrados 82 artigos, dos quais apenas 35 estavam em concordância com esse estudo.

Após a triagem dos artigos de acordo com as palavras de inclusão, foram seguidos os seguintes passos: leitura exploratória, leitura seletiva com a escolha dos artigos com relevância para o tema deste estudo, leitura analítica, por fim a leitura interpretativa e escrita do estudo. 


\section{RESULTADOS}

\subsection{ASPECTOS ECONÔMICOS DA PRODUÇÃO DO PLÁSTICO VERDE}

A indústria petroquímica é parte da indústria química. Caracteriza-se por utilizar um derivado de petróleo (a nafta) ou o gás natural como matérias-primas básicas. Considerando todos os seus segmentos (produtos químicos industriais, farmacêuticos, fertilizantes, higiene pessoal, perfumaria e cosméticos, defensivos agrícolas, sabões e detergentes, tintas, esmaltes e vernizes, fibras artificiais e sintéticas e outros), a indústria química teve, em 2018, um faturamento líquido estimado de US\$127,9 bilhões. 0 faturamento líquido do segmento de produtos químicos industriais, acompanhado mais de perto pela Associação Brasileira da Indústria Química (ABIQUIM), atingiu em 2018 o valor estimado de US\$ 65,2 bilhões. Em termos de faturamento líquido, é a sexta maior do mundo. A comparação tem como base o ano de 2017 e refere-se à indústria química como um todo, uma vez que em muitos países não há estatísticas por segmento (ABIQUIM).

Em busca de alternativas para a competitividade de mercado interno e externo, eficiência energética, inovação, as alternativas ambientalmente correta tornou-se uma tendência de mercado e a substituição do plástico de origem fóssil ou polietileno fóssil, pelo polietileno verde que é obtido do etanol de cana-deaçúcar. É um mercado muito importante no Brasil, quanto para o mundo, uma vez que os "plásticos" mais importantes são produtos muito utilizados no Brasil e grande parte do mundo.

Há uma preocupação para que a expansão do cultivo da cana não concorra com áreas de produção de alimentos, porém a cana tem a capacidade de ser cultivada em áreas degradadas.

De acordo com bresciani et al. (2014) são necessários 325 mil hectares de plantação de cana-de-açúcar para uma produção de um milhão de toneladas de plástico verde por ano. Considerando que o mundo consome, atualmente, 50 milhões de toneladas de plástico (desconsiderando reciclados), para a total substituição do plástico de resinas fósseis pelo plástico verde, seriam necessários mais de 16 milhões de hectares para a plantação de cana-de-açúcar, somente para essa destinação, o que equivale a cerca de $25 \%$ da área agrícola atual do brasil. Desta forma, a melhoria da eficiência das plantações e o cultivo de cana em terras degradadas e de políticas de reciclagem tornam-se fundamentais para o sucesso deste processo.

Segundo com a empresa brasileira granbio a produção cana-de-açúcar possui grandes vantagens e pode ser plantada em áreas com baixa aptidão agrícola, o que permite a exploração de regiões desfavorecidas e o aumento da produtividade por hectare, além de não competir com a produção de alimentos. 0 Brasil tem 32 milhões de hectares de pastagens degradadas que podem ser ocupadas com cana-de-açúcar, mais do que toda a área agricultável da europa.

Em termos da produção canavieira, de 2000 a 2014, a área plantada cresceu na magnitude de aproximadamente 5,6 milhões de hectares no território nacional, sendo 3,1 milhões apenas no estado de São Paulo. Em termos de produção, o acréscimo foi de cerca de 410 milhões de toneladas no Brasil e 212 milhões de toneladas em São Paulo, auferindo, respectivamente, ganhos econômicos de r\$ 35 bilhões e r\$ 18 bilhões no valor de sua produção (CAPITANI et al., 2019).

O estudo de Capitani et al. (2019), analisa que a expansão canavieira no estado de São Paulo trouxe, proporcionalmente, impactos econômicos substancialmente positivos, oferta de alimentos não se retraiu de forma significativa e os ganhos econômicos mais que compensaram as perdas, possibilitando inclusive, de financiar a importação de alimentos de outros estados mais eficientes na produção destas culturas, havendo uma dinamização de diferentes indicadores econômicos regionais, como geração de empregos, incrementos na atividade econômica como um todo.

Outro fator interessante no uso do etanol para a produção do plástico verde é sobre a variação do preço do barril do petróleo, que pode ser politicamente controlado, a depender dos interesses dos maiores produtores mundiais. Por outro lado, o preço do eteno verde depende de fatores mais técnicos tais como clima, tipo de matéria-prima utilizada na produção do etanol, tecnologia empregada na desidratação do etanol (HELLVIG et al., 2020).

A implantação de programas ambientais visando a sustentabilidade colabora com o desempenho econômico da atividade, através do melhor aproveitamento dos recursos. Em relação aos aspectos sociais, o custo da responsabilidade social das empresas no curto prazo pode parecer alto, mas é compensado a longo prazo. Mas iniciativas das empresas para melhorar as condições de trabalho, com segurança e saúde, podem resultar em economia através da redução do absenteísmo e dos acidentes de trabalho (GIMENEZ et al., 2012). 


\subsection{ASPECTOS SOCIAIS DA PRODUÇÃO DO PLÁSTICO VERDE}

O mercado globalizado pede novidades no campo da sustentabilidade e para quem quer atuar nesse mercado competitivo é preciso, salientar o interesse e a prática de condutas voltadas à responsabilidade social. Nesse aspecto a ideia de sustentabilidade aqui defendida está vinculada de forma indissociável das questões econômicas e sociais.

Nos últimos anos a sociedade, por meio das organizações, se mostra atenta, com relação ao comportamento das empresas quanto responsabilidade social. As empresas com atitudes sustentáveis deve se preocupar com a qualidade de vida das populações (DENAIRE, 1994).

O estudo de Barbieri (2010) considera que para uma empresa ser considerada sustentável seus gestores devem procurar a eficiência, indo além dos aspectos econômicos e do respeito ao meio ambiente, é dever, também, promover "a inclusão social, a proteção às minorias e grupos vulneráveis, e o equilíbrio entre os gêneros". O fato é que a responsabilidade social de uma empresa pode provocar grande impacto no contexto da região em que ela está inserida e em seus colaboradores. Assim, a empresa precisa definir como será a sua atuação e isso pede boas práticas internas e externas, alcançando os funcionários e a comunidade.

Para avaliar os aspectos sociais da produção do plástico verde, sob o enfoque dos recursos humanos, foram estudados os impactos no cultivo e colheita da cana-de-açúcar, para os trabalhadores envolvidos, pois o ciclo de vida do PE verde tem início no cultivo da cana.

Segundo Alves (2006), o corte manual da cana-de-açúcar é um trabalho pesado e extenuante, principalmente porque o pagamento do trabalhador é feito em função a sua produtividade, com isso os cortadores de cana trabalham exaustivamente causando danos a sua saúde. Uma solução a esse problema é a mecanização completa do corte de cana, mas a mesma não pode ocorrer em terrenos que apresentam declividade acima de $12 \%$, pelo risco de tombamento das máquinas e queda da produtividade do equipamento. Mas para que a mecanização do corte não cause impactos sociais, como o desemprego, é necessário a criação de novos postos de trabalho que absorvam esses trabalhadores.

No entanto, Alessi e Navarro (1997) afirmam que a mecanização da cana-de-açúcar piora as condições de trabalho e saúde dos cortadores, pois para que a utilização de máquinas seja possível e viável, o solo deve ter pouca declividade. Onde o solo é irregular o corte da cana deverá ser feito pelos trabalhadores, local esse que as condições de trabalho são prejudiciais e a produtividade é baixa, necessitando de mais incentivos às condições de trabalho.

Como esses trabalhadores possuem pouca qualificação, são necessárias políticas públicas e privadas, do setor sucroalcooleiro, com incentivo a cursos de capacitação desses trabalhadores para assumir novos postos de trabalho em outros setores (MORAIS; SORDI, 2013).

Com o objetivo de tornar o plástico verde sustentável na esfera social, em 2009, a braskem firmou um comum acordo entre o Governo, as indústrias e os sindicatos dos trabalhadores, o Compromisso Nacional para Aperfeiçoar as Condições de Trabalho na Atividade Canavieira, que visa a melhores práticas de trabalho, relações de trabalho e qualidade de vida aos trabalhadores. Para a recolocação dos trabalhadores cortadores de cana que foram substituídos pela mecanização no cultivo e colheita da cana-de-açúcar, a BRASKEM implantou o Programa de Requalificação de Trabalhadores da Cana-de-Açúcar (RenovAção) visando o treinamento e a qualificação desses trabalhadores (BRASKEM, 2020).

No estudo de Ripoll et al. (2018), observou-se que a BRASKEM, vem se valendo de conceitos tais como sustentabilidade e inovação tecnológica numa forma de ação que visa o mercado e o consumo. Mas é visível, no aspecto social a busca para se enquadrar, lançando mão de programas sociais que abrangem condutas que reforçam a imagem de prestadora de serviços que está em prol dos seus funcionários e da sociedade.

Com a propagação do termo sustentabilidade, muitas empresas incorporaram ao seu perfil o discurso sustentável e com ele tiveram que se adequar a uma nova visão. Nesse contexto, cabe a esses empreendimentos trabalhar e executar as ações provenientes do desenvolvimento sustentável, entre elas o aspecto social, porém aliado aos aspectos econômicos e ambientais. 


\section{CONCLUSÕES}

Os resultados dos levantamentos da literatura indicam que o plástico verde tem uma relevante capacidade de inovação, com a utilização de material renovável para os seus processos produtivos, podendo diminuir a extração de petróleo, objetivando a preservação ambiental e o desenvolvimento sustentável.

Sobre os aspectos sociais, verificou-se que o produtor do plástico verde investe em programas de qualificação e treinamento dos cortadores de cana, investindo também em vários programas sociais para a comunidade. Relacionado aos aspectos econômicos pode-se destacar o desenvolvimento das regiões produtoras de cana e pela capacidade de cultivo em terras degradadas, evitando a concorrência com a agricultura de alimentos.

O plástico verde proveniente do etanol da cana-de-açúcar mesmo não sendo um produto biodegradável é um produto cem por cento reciclável e quando é avaliado no aspecto global o polietileno verde é mais sustentável em relação ao plástico de origem fóssil, sendo assim verifica-se ganhos desde a substituição da matéria prima até no processo de produção do etanol.

\section{REFERÊNCIAS}

[1] ABIQUIM, Associação Brasileira da Indústria Química. Disponível em: <https://abiquim.org.br/>. Acesso em: 10 de jun. de 2020.

[2] ALESSI, N. P.; NAVARRO, V. L. Saúde e trabalho rural: o caso dos trabalhadores da cultura canavieira na região de Ribeirão Preto, São Paulo, Brasil. Caderno Saúde Pública. Rio de Janeiro,v. 13, suppl 2, p. 111-121, 1997.

[3] ALVES, F. Por que morrem os cortadores de cana? Saúde e Sociedade, São Paulo, v. 15, n.3, p. 90-98, set./dez. 2006

[4] ANDRADE, S. M. de et al. Inovação no desenvolvimento de plástico "verdes" e com menores carbon footprints: o caso do polietileno de álcool de cana de açúcar da Braskem. IV Encontro de estudos em estratégia. Recife, 2009.

[5] ANDREOLI, C.; SOUZA, C. Cana-de- açúcar: a melhor alternativa para conversão da energia solar e fóssil em etanol. Economia \& Energia, Ano $\mathrm{X}, \mathrm{n} \quad 59, \quad 2007 . \quad$ Disponível em:<http://ecen.com/eee59/eee59p/cana_melhor_conversorl.htm>. Acesso em: 20 de jul. de 2020.

[6] BOA VISTA, H. A.; SHIBAO. F.Y.; SANTOS. M. R. Produto Sustentável: Equipamentos de Proteção Individual Fabricado com Plástico Verde. Revista de Gestão Ambiental e Sustentabilidade. - GeAS. v. 4, n. 1. p. 59-71 jan. /abr. 2015.

[7] BARBIERI, J. C. et al. Inovações e Sustentabilidade: Novos Modelos e Proporções. Revista de Administração de Empresas (RAE). São Paulo. v. 50. n. 2, p. 146-154, abr./jun. 2010.

[8] BARICHELLO, R. et al. Sustainability and innovation in the Brazilian supply chain of green plastic. Journal of Cleaner Production, v. 177, p.12-18, mar. 2018.

[9] BRASKEM. Disponível em: <https://www.braskem.com.br/>. Acesso em: 10 de jun. de 2020.

[10] BRESCIANI, L. P. et al. Sustentabilidade e inovação: um estudo sobre o plástico verde. Revista em Agronegócios e Meio Ambiente, Maringá, v. 7, n. 2, p. 429-453, maio/ago. 2014.

[11] CAPITANI, D. H. D. et al. Expansão da cana-de-açúcar e os impactos sobre culturas agroalimentares no estado de São Paulo. Revista científica da fundação educacional de Ituverava - Nucleus, v. 16, n. 1, p. 259-276, abr. 2019.

[12] CMMAD - COMISSÃO MUNDIAL SOBRE MEIO AMBIENTE E DESENVOLVIMENTO. Nosso Futuro Comum. Editora da Fundação Getúlio Vargas, Rio de Janeiro, 2. ed., 1991.

[13] DENAIRE, D. Considerações Sobre a Influência da Variável Ambiental na Empresa. Revista de Administração de Empresas (ERA). São Paulo. v. 34, n. 2, p. 68-67, mar./abr. 1994.

[14] EISELE, F. V. P. et al. Inovação sustentável na cadeia de suprimentos do plástico verde a partir da ótica do ciclo de vida do produto. XVI Congresso latino-liberoamericano de gestão de tecnologia (ALTEC), Porto Alegre, out. 2015.

[15] EUROPEAN BIOPLASTICS. Disponível em:<https://www.european-bioplastics.org/bioplastics/> Acesso em: 23 de julho de 2020.

[16] FARAH, D. et al. Green plastics: analysis of a firm's sustainability orientation for innovation. Revista de Gestão Ambiental e Sustentabilidade (GeAS), São Paulo, v. 5, n. 3, p. 21-35, set./dez. 2016.

[17] FIDALGO NETO, A. A. et al. Desenvolvimento da química verde no cenário industrial brasileiro. Revista Fitos. Rio de Janeiro, edição especial p. 80-89, 2018. 
[18] GIMENEZ, C. et al. Sustainable operations:Their impact on the triple bottom line. International Journal of Production Economics, v. 140 (1), p.149-159, nov. 2012.

[19] GRANBIO, 2020. Online. Disponível em:< http://www.granbio.com.br/>. Acesso em: 10 de jun. de 2020.

[20] HELLVIG, E. L. et al. Estudo do uso de eteno verde ou fóssil na síntese de pead e pelbd nominalmente iguais: há diferença efetiva entre esses materiais?/Study on the use of green or fossil ethene in the synthesis of hdpe and pelbd nominally equal: is there an effective difference between these materials? Brazilian Journal of Development, v. 6, n. 5, p. 25473-25487, 2020.

[21] MAÇANEIRO, M. B.; CUNHA, S. K. Relações entre fatores contextuais internos às organizações e a adoção de estratégias proativas e reativas de ecoinovações. Revista de Administração Mackenzie, v. 16, n. 3, p. 20-50, 2015. Disponível em: <http://editorarevistas.mackenzie.br/index. php/RAM/article/view/6837>. Acesso em 27 de jul. de 2020.

[22] MASCARENHAS, J. M. G. A. J. Bioplásticos e plásticos biodegradáveis surfando a sexta onda: um estudo sobre a ecoeficiência. Revista Valore, Rio de Janeiro, v. 4, p. 133-142, jan. 2020.

[23] MELLO, A. et al. Polímeros Verdes - tecnologia para promoção do desenvolvimento sustentável. Investimentos transformadores para um estilo de desenvolvimento sustentável: Estudos de casos de grande impulso (Big Push) para a sustentabilidade no Brasil. Brasília: CEPAL. p. 75-88, maio 2020

[24] MORAIS, S. P.; SORDI, D. N. de. Deveriam os cortadores de cana-de-açúcar se qualificar? Modificações e permanências no trabalho agroindustrial no triângulo mineiro. Revista HISTEDBR On-line. Campinas, no 50 (especial), p. 172-192, maio 2013

[25] OLIVEIRA, L. R. et al. Sustentabilidade: da evolução dos conceitos à implementação como estratégia nas organizações. Produção, v. 22, n. 1, p. 70-82, jan./fev. 2012.

[26] RIPOLL, D. et al. Educação ambiental corporativa: o caso do marketing "sustentável" do plástico verde da Braskem. Revista Eletrônica do Mestrado em Educação Ambiental, Rio Grande, v. 35, n. 2, maio/ago. 2018.

[27] SILVA, S. M.; YAMAGUCHI, C. K.; VIEIRA, A. C. P. Perspectiva da ecoinovação nas organizações. Revista Livre de Sustentabilidade e Empreendedorismo. v. 3, n. 6, p. 214 - 229, nov./dez. 2018. Disponível em: <http://relise.eco.br/index.php/relise/article/viewFile/203/188>. Acesso em: 27 de jul. de 2020.

[28] UNICA_ União das Indústrias de Cana-de-Açúcar. Disponível em: <https://unica.com.br/noticias/combate-apoluicao-sera-prioridade-em-saude/> Acesso em: 27 de jul. de 2020.

[29] WBCSD - World Business Council for Sustainable Development. Eco-efficiency Learning Module, 2006. Disponível em: <http://docs.wbcsd.org/2006/08/EfficiencyLearningModule.pdf> Acesso em: 10 de jun. de 2020. 


\section{Capítulo 10}

Empreendedorismo social e sustentabilidade: Análise acerca do trabalho das mulheres membras da Cooperativa de Mulheres Artesãs do Poti Velho (COOPERART-Poti) em Teresina-Piauí

\section{João Lucas Queiroz Brandão \\ Ione Cristina Dantas Ribeiro}

Resumo: 0 presente artigo intitulado "Empreendedorismo Social e Sustentabilidade: análise acerca do trabalho das mulheres membras da Cooperativa de Mulheres Artesãs do Poti Velho (COOPERART- Poti) em Teresina-Piauí" é resultado do Trabalho de Conclusão do Curso de Serviço Social. A motivação pessoal para a pesquisa surgiu a partir do consumo por parte deste pesquisador dos produtos da COOPERART-Poti e por meio da realização de um trabalho acadêmico na referida cooperativa. Assim, a produção tem como objetivo geral analisar o trabalho das mulheres membro da Cooperativa de Mulheres Artesãs do Poti Velho (COOPERART-Poti) em Teresina-Piauí, enquanto prática de empreendedorismo social voltada para sustentabilidade. Quanto aos objetivos específicos da pesquisa, estes foram: contextualizar o papel social e econômico da mulher na sociedade; discutir conceitualmente sobre empreendimentos sociais, destacando o empreendedorismo feminino e descrever os impactos e desafios vivenciados pelas participantes da COOPERART-Poti no que se refere a sua experiência no empreendedorismo feminino. Trata-se de uma pesquisa de campo com abordagem qualitativa, de caráter exploratória e descritiva, fundamentada no método materialismo histórico dialético. Para tanto, foram realizadas entrevistas semiestruturadas com a participação de cinco artesãs da cooperativa em questão. Os principais autores trabalhados foram: Magalhães (1980); Neto e Froes (2002); Sachs (2002); Elkington (2012) e Tyszler (2002). A partir do estudo realizado, foi possível compreender que a COOPEART Poti promove melhoria na qualidade de vida e autonomia as suas cooperadas, as oportunizando independência financeira, numa lógica de preservação do meio ambiente.

Palavras-Chave: Empreedimentos Sociais. Sustentabilidade. Artesanato. Cooperadas. Cultura. 


\section{INTRODUÇÃO}

0 presente artigo refere-se a uma pesquisa centrada nos aspectos da sustentabilidade em sua dimensão social, ambiental e econômica, como forma de contribuir para transformação social e na tentativa de supressão de problemas sociais por meio dos empreendimentos sociais. Destaca-se ainda a importância das práticas socioeconômicas, culturais e institucionais das artesãs na cooperativa em questão como forma de geração de renda e protagonismo social.

Para início da discussão, é importante destacar os empreendimentos sociais, que são alternativas de negócios que buscam melhorar a situação econômica de um determinado grupo ou indivíduo e ainda se configuram como uma forma de tentar sanar os problemas sociais contemporâneos.

De acordo com Rosolen (2014), os empreendimentos sociais surgem a partir das inquietações de grupos ou indivíduos com os problemas de ordem social e econômica enfrentados no cotidiano, buscam na criação de valor social e introdução de inovações tecnológicas, serviços ou produtos capazes estimular mudança social.

Diante do modelo de consumo vigente na sociedade atual alinhado a um padrão de produção insustentável, explora-se os recursos naturais de forma desenfreada causando danos ambientais por um lado e ampliando as desigualdades sociais do outro. Todavia, tem-se percebido uma mudança no padrão comportamental do consumidor brasileiro, que passa a buscar produtos sustentáveis. Os empreendimentos sociais entram no rol de escolhas dos chamados consumidores sustentáveis ou "consumidores verdes" que no ato de adquirir, utilizar e descartar bens e serviços tem respeito ao meio ambiente e à dignidade humana.

O interesse pela pesquisa se deu a partir de uma visita para um trabalho acadêmico no Polo Cerâmico do Poti Velho em Teresina-Piauí e pelo fato do pesquisador ser consumidor de produtos da COOPERART-Poti. Do ponto de vista social, a pesquisa adquire singular pertinência, pois permite disseminar, técnica e teoricamente, pensando-se nas gerações futuras, a importância das discussões sobre a integração social dos empreendedores, valorização cultural e o desenvolvimento sustentável.

Diante do exposto, formulou-se o seguinte problema de pesquisa: como se desenvolve o trabalho das mulheres membro da Cooperativa de Mulheres Artesãs do Poti Velho (COOPERART-Poti) em TeresinaPiauí?

Utilizou-se o método qualitativo, construindo a pesquisa a partir de uma pesquisa de campo com entrevistas semiestruturadas. A COOPERART-Poti possui trinta e nove associadas e fica localizada no Polo Cerâmico do Poti Velho em Teresina-Piauí. Foram convidadas 05 (cinco) artesãs para participarem das entrevistas, sendo os critérios de escolha o tempo mínimo de 3 anos de atividade na cooperativa.

O objetivo geral desse estudo foi analisar o trabalho das mulheres membro da Cooperativa de Mulheres Artesãs do Poti Velho (COOPERART-Poti) em Teresina-Piauí, enquanto prática de empreendedorismo social voltada para sustentabilidade. 0 trabalho em questão possuiu como objetivos específicos: contextualizar o papel social e econômico da mulher na sociedade; discutir conceitualmente empreendimentos sociais, destacando empreendedorismo feminino; descrever os impactos e desafios vivenciados pelas participantes da COOPERART-Poti no que se refere a sua experiência no empreendedorismo feminino.

0 presente artigo apresenta uma estruturação teórica dividida em quatro itens: o primeiro traz um breve apanhado histórico sobre o papel social da mulher e seus respectivos desdobramentos no mercado de trabalho; no item dois é discutido os conceitos de desenvolvimento sustentável e sustentabilidade destacando as principais diferenças e consensos entre os termos; o item três aborda os conceitos e características acerca dos empreendimentos sociais. 0 item três trata da metodologia da pesquisa e o item cinco traz a discussão sobre a Cooperativa de Mulheres Artesãs do Poti Velho (COOPERART- Poti) e os desafios enquanto empreendimento feminino, neste item encontra-se a análise dos resultados a partir da coleta de informações realizada na referida cooperativa, seguido das considerações finais.

\subsection{ASPECTOS DA SÓCIO HISTÓRICOS DA MULHER: ENFOQUE SOB O MUNDO DO TRABALHO}

A história da mulher na sociedade é marcada por um passado e presente de lutas por direitos, considerando que ainda há uma forte presença do machismo em um contexto social marcado pelo 
patriarcalismo ${ }^{2}$. Desde os tempos mais remotos, a mulher sempre sofreu discriminações, ocupando um papel de submissão com relação ao homem, com a privação de direitos básicos e princípios como a liberdade, sendo que em algumas sociedades ela era tida como mercadoria ou apenas como objeto sexual.

Na Antiguidade, a condição da mulher em todos os contextos era de total submissão ao homem. Este tipo de dominação tinha por base a ideia posta pela igreja católica de que o ser masculino era superior. A igreja, por meio de interpretações da bíblia, propunha também uma "castração" da mulher, pois, a mesma carregava o peso do pecado original, segundo a referida instituição, remetendo à história de Adão e Eva, conforme informa Silva et al. (2005).

No avançar da história tais ideais sucumbiram, as sociedades passaram por modernizações em suas relações econômicas e políticas, sendo configurados novos direitos sociais e estabelecidos novos mercados, a partir da Idade Moderna. Grandes revoluções demarcaram a presença de mulheres em espaços como o de trabalho e da vida pública, a começar pela Revolução Francesa em 1978 que pregava a liberdade, igualdade e fraternidade como direitos essenciais à vida.

Com a chegada da I Revolução Industrial no final do Século XVIII, foram observadas transformações na economia, nas relações sociais e de trabalho, levando a um crescimento acelerado dos centros urbanos, sendo substituído o meio de produção artesanal pelas grandes manufaturas industriais, com o uso de máquinas que produziam em série, reduzindo os custos de produção e demandando mão de obra com menor especialização, não havendo a necessidade de força muscular excessiva, segundo Hobsbawm (2000), o que acabou por abrir espaços, mesmo de que de forma exploradora, para as mulheres atuarem.

De acordo com Teixeira (2009), a inserção da mulher no mercado de trabalho era subalternizada sendo ocupadas:

[...] posições fragmentadas do saber fazer e do ter o conhecimento técnico para determinado ofício, e, consequentemente, a valorização e remuneração dos respectivos trabalhos, que fazem com que as mulheres se organizem na tentativa de estabelecer relações igualitárias entre homens e mulheres no mundo do trabalho. (TEIXEIRA, 2009, p. 238)

A participação da mulher nas fábricas era interna, onde estas desempenhavam funções subalternas e com limitação de postos de trabalho na indústria. A mulher voltava a desempenhar as funções ditas femininas, retornando, muitas vezes, ao trabalho do lar (MATOS; BORELLI, 2016).

Desta feita, o sistema patriarcal vai sustentar por anos a visão de que a mulher no mercado de trabalho acabaria por dissolver as relações familiares de servidão ao marido e prejudicaria sua imagem perante à sociedade. Mesmo visto como degradante por séculos, a inserção do trabalho feminino adquiriu singular importância na construção da história da mulher como um "mediador para que as mulheres exercessem atividades além dos muros de suas residências, ocupando posições sociais e determinadas atividades profissionais até então permitidas e validadas única e exclusivamente para homens" (TEIXEIRA, 2009, p. 238).

Com a modernização dos grandes centros urbanos e criação de oportunidades no mercado de trabalho e no cenário político, houve de fato a quebra de padrões dos papéis das mulheres na sociedade. Desta forma, questões como urbanização e industrialização dos grandes centros do país, além da própria profissionalização das mulheres, são aspectos importantes para entender a presença feminina em determinados espaços ocupacionais.

Assim, como a divisão de tarefas no lar ainda não era absoluta, a mulher assumiu a dupla jornada: a do trabalho profissional e a de cuidar dos filhos, se tornando um desafio conciliar as demandas no dia a dia. Em outras palavras, socialmente recai sobre a mulher, de modo quase exclusivo, a responsabilidade de conciliar trabalho e vida doméstica, o que fica mais evidente no percentual de $91 \%$ de mulheres que eram economicamente ativas e que realizavam atividades domésticas, especialmente até final do século XIX (PASSOS; GUEDES, 2018).

Com uma crescente recusa ao trabalho exclusivamente doméstico, a participação feminina no mercado de trabalho aumentou, aspecto confirmado a partir dos dados da PNAD (2015) que mostram que em 1970 a

\footnotetext{
20 patriarcalismo aparece neste texto, não só em sua forma de dominação restrita ao âmbito familiar, mas também nas suas formas institucionais, como a divisão de papeis no mercado de trabalho, sendo marcado por desigualdades e violência contra a mulher, tendo sua origem na cultura e instituições que ainda são fundadas no sistema patriarcal. (CASTELLS, 2010).
} 
participação da mulher no mercado de trabalho não atingia 20\%, já em 2010 alcança o patamar de 49\%, evidenciando um avanço da ocupação feminina em espaços laborais, passando a desenvolver ações em diferentes áreas, com preocupações que vão desde a sua subsistência financeira até a preocupação com o meio ambiente.

\section{O DESENVOLVIMENTO SUSTENTÁVEL E SUSTENTABILIDADE: CONSIDERAÇÕES TEÓRICAS}

Para se discutir empreendedorismo social e sustentabilidade, a partir da experiência da Cooperativa de Mulheres Artesãs do Poti Velho (COOPERART- Poti) em Teresina-Piauí, é necessário compreender conceitualmente desenvolvimento sustentável e sustentabilidade.

Assim, para este trabalho, se faz necessário evidenciar a diferença entre os conceitos de desenvolvimento sustentável e sustentabilidade que são comumente confundidos e muitas vezes tratados como sinônimos, faltando um consenso sobre ambos os termos. 0 primeiro termo, conforme Moldan et al. (2012), se concentra principalmente nas pessoas e seu bem estar. O segundo, de acordo com Ayres (2008), está centrado na maneira como os seres humanos se comportam em relação à natureza, são os atos do cotidiano que contribuem para o bem do planeta e sua responsabilidade com as futuras gerações.

0 conceito de desenvolvimento sustentável pela definição clássica discutida no Relatório de Brundtlan ${ }^{3}$ é

[...] aquele que atende às necessidades do presente sem comprometer a capacidade de as gerações futuras atenderem as suas próprias necessidades. É, em essência, um processo de transformação no qual a exploração dos recursos, a direção dos investimentos, a orientação do desenvolvimento tecnológico e a mudança institucional se harmonizam e reforçam o potencial presente e futuro, a fim de atender às necessidades e aspirações humanas. (RELATÓRIO BRUNDTLAN, 1987, s/p.)

O conceito atual de desenvolvimento sustentável, que foi expresso na Cúpula Mundial em 2002, diz que o DS procura a melhoria da qualidade de vida de todos os habitantes do mundo sem aumentar o uso de recursos naturais além da capacidade da Terra. Ainda sob a visão de Sachs (2002), o desenvolvimento sustentável é conceituado a partir de 8 dimensões da sustentabilidade na medida em que somente se considera desenvolvimento sustentável o atingimento de todas "as dimensões, quais sejam, ambiental, econômica, social, cultural, espacial, psicológica, política nacional e internacional".

O desenvolvimento sustentável não representa um estado estático de harmonia, mas, antes, um processo de mudança, no qual a exploração dos recursos, a dinâmica dos investimentos, e a orientação das inovações tecnológicas e institucionais são feitas de forma consciente face às necessidades tanto atuais quanto futuras. (SVEDIN, 1987 apud Sachs, 2002, p.474).

O desenvolvimento sustentável deve partir não só por meio de políticas públicas do Estado para preservação dos recursos naturais, cabe também as empresas buscarem estratégias que possam aliar tais dimensões, considerando que há um avanço cada vez maiores de recursos tecnológicos que possibilitam o uso dos meios naturais e potencializam a produção com o mínimo de perdas e a responsabilidade da sociedade em suas práticas diante ao meio ambiente sempre pensando na sustentabilidade.

O termo sustentabilidade é alicerçado por três fatores: econômicos, ambientais e sociais, e caracterizado pela busca da harmonia entre eles, sem que se esgote os recursos naturais, formando o famoso termo "tripé" da sustentabilidade, termo criado por John Elkington em 1999.

O crescimento econômico, no âmbito sustentável, leva em consideração práticas financeiras, econômicas e administrativas, sem degradar o meio ambiente e garantindo a manutenção dos recursos naturais. A responsabilidade ambiental é o conjunto de atitudes, tanto de empresas quanto de pessoas, que promove o desenvolvimento sustentável do planeta. A responsabilidade social trata do bem-estar do capital humano de um empreendimento ou sociedade como um todo, ou seja, é o compromisso das empresas com pessoas e valores humanos. (ELKINGTON, 2012, p. 20).

\footnotetext{
3 Relatório Brundtland é o documento intitulado Nosso Futuro Comum, publicado em 1987, elaborado pela Comissão Mundial sobre Meio Ambiente e Desenvolvimento, faz parte de uma série de iniciativas, anteriores à Agenda 21.
} 
O debate acerca da sustentabilidade apresenta um crescimento nas esferas acadêmicas, empresariais e governamentais como ato político traduzido a partir de regulamentações ambientais, que por muito tempo ficou restrito aos aspectos ecológicos. Atualmente o referido debate abrange também a questão social como problemática, sendo que cada vez mais a preocupação com o futuro do planeta frente à finitude dos recursos naturais é eminente diante do padrão de produção, exploração e consumo insustentáveis.

Sachs apud Oliveira (2002, p.43) aponta cinco dimensões de sustentabilidade dos sistemas econômicos, que "devem ser observadas para se planejar o desenvolvimento: social, econômico, ecológico, espacial e cultural". Como discutido pelo autor acima, o tema sustentabilidade é concebido de forma ampla, pois na configuração atual carrega simultaneamente 4 conceitos: a sociedade ecologicamente correta; a justiça social como forma de oferecer condições igualitárias aos indivíduos para acessar seus direitos; o economicamente viável com adequação dos meios de produção que sejam mais baratos e menos agressivos ao planeta, além da preservação do meio ambiente, remetendo assim, o pensamento de onde vem tudo que nós usamos, passando também a englobar a integração cultural e a valorização das heranças, respeitando cada povo/nação.

Para que uma sociedade se torne sustentável, é necessário, como já citado, que haja uma harmonia das atividades humanas com o meio ecológico, prezando também pela resolução dos problemas sociais na atualidade, com vistas, inclusive, à contemplação de futuras gerações (FOLADORI, 1999). Sendo assim, as medidas tomadas no âmbito da sustentabilidade não devem estar com um olhar somente para o futuro. Devem sim, ser implementadas visando beneficiar, inclusive, as atuais gerações.

Conforme Silva (2008), aos poucos, as instituições, como esferas governamentais e econômicas, estão se conscientizando sobre a pauta da sustentabilidade, buscando integrar de forma correlata, evidenciando assim, um ponto positivo da sustentabilidade, o qual se configura basicamente na mudança dos padrões culturais da população na atualidade. Esses, por sua por vez, influenciam diretamente na produção e nos produtos das empresas, bem como no processo de descarte de lixos e resíduos.

Entretanto, apesar dos avanços no mercado, a ideia da sustentabilidade sofre grande resistência por parte das empresas, pois, a busca para unir interesses em lados opostos da concepção de desenvolvimento sustentável quase sempre esbarra no lucro financeiro, pois implantar reformas para conciliar produção e interferir meio ambiente pode interferir nos rendimentos empresariais.

As empresas atualmente buscam ampliar as suas ações no campo da sustentabilidade baseadas no comportamento dos consumidores. No entanto, ainda é presada a dimensão econômica sob as outras, deixando a lógica ambientalista em segundo plano ou como medida complementar. Sendo assim, produtos e produção voltados para sustentabilidade, não se caracterizam como um negócio rentável do ponto do lucro em primeiro plano, pois, conforme Elkington (2001, p. 429),

[...] o desenvolvimento sustentável envolve a busca simultânea da prosperidade econômica, da qualidade ambiental e da igualdade social. As empresas que buscam a sustentabilidade precisam empenhar-se não somente na direção de uma única linha de resultados, a financeira, mas sim na linha dos três pilares.

Desta feita, o exposto acima concorda com o pensamento de Claro e Amâncio (2008), as quais destacam que as empresas têm dificuldade em associar seus discursos, não havendo uma definição clara acerca da sustentabilidade, pois, muitas delas buscam apenas gerenciar suas práticas, almejando o lucro financeiro, sem elaboração de um plano para incluir as preocupações sociais e ambientais, como mandam as agendas governamentais para o desenvolvimento sustentável.

Ainda há um longo caminho a percorrer, visto que com o passar do tempo a sociedade se torna cada vez mais consumista, havendo um descuido com relação ao meio ambiente, em práticas que podem parecer inofensivas como jogar um papel no chão ou atos como comprar um produto que com seu descarte incorreto irá trazer malefícios para a natureza e até riscos à própria saúde.

Logo, na medida em que se avançam as discussões e elaborações de políticas e planos para criar uma sociedade responsável com o meio ambiente, observa-se que muitos países de terceiro mundo permanecem sem tomar providências contundentes; criar algum plano de contingência ou mesmo estratégia para uso de recursos naturais. Em alguns países desenvolvidos, o modelo de crescimento que busca incremento de capital não atende às necessidades humanas (HERCULANO, 1992).

Desta feita, se tornar sustentável está no saber e na consciência de que os atos da sociedade para com o meio ambiente fazem toda a diferença. Por menor que a iniciativa seja, há uma perspectiva de contribuição 
para melhoria das condições de vida e bem estar socioambiental das gerações. Eis importância de se criar hábitos no cotidiano, seja de cunho individual e/ou coletivo, pensando no planeta e nas gerações futuras, o que inclui serviços e iniciativas de trabalho, como é o caso dos empreendimentos sociais que se dedicam ao labor cooperativo, sem perder de vista o enfoque ambiental, como será visto a seguir.

\section{EMPREENDIMENTOS SOCIAIS: CONCEITOS E CARACTERÍSTICAS}

Diversos autores abordam os empreendimentos sociais como temática em expansão mundial, visto que há um significativo crescimento na participação da sociedade civil no combate às expressões da questão social que se dispõem de maneiras diferentes de acordo com as realidades locais.

No Brasil, as primeiras iniciativas de empreendimentos sociais surgem no bojo das transformações societárias que estavam em curso no país, como a consolidação do processo de abertura democrática nos anos de 1980, ocorrendo "[...] ante a crescente problematização social, a redução dos investimentos públicos no campo social, o crescimento das organizações do terceiro setor e da participação das empresas no investimento e nas ações sociais." (OLIVEIRA, 2004, p. 17).

Muitos desses negócios surgem de iniciativa pessoal e na maior parte deles não há essa apropriação do conceito de empreendimento social no qual se encaixam. Alguns surgem por meio de grupos sociais que se preocupam com as manifestações da questão social e suas expressões como desemprego, exclusão social, preconceito racial ou do manifesto de insatisfação das ações governamentais que não abrangem certas parcelas da sociedade. Na visão de Bastos et al (2013, s/p), estes negócios:

[...] uma nova tecnologia social, com imensa capacidade de inovação no processo de empreender em "novas estratégias de ação", gerando, com isso, "outras ações que afetam profundamente o processo de gestão social", já que não pretende-se assistencialista e mantenedora, mas empreendedora, emancipadora e transformadora.

Considerando a citação anterior, é importante destacar que a visão colocada sobre os empreendimentos sociais é de que eles são arranjos formais de solidariedade. Muitas vezes são tidos como empreendimento tradicional que buscam apenas o retorno financeiro. Porém, os empreendimentos têm grande importância no contexto social no qual estão envolvidos, pois, muitas vezes o produto comercializado, mais do que gerar renda, simboliza uma luta ou questão representativa do lugar do qual o/a empreendedor/a faz parte.

Os aspectos culturais e a preservação da identidade cultural nos empreendimentos sociais são fortes atributos, pois, muitos desses negócios utilizam a arte representativa e por sua vez, acabam contribuindo para um movimento de preservação cultural, em alguns momentos, e até mesmo de desenvolvimento e fortalecimento de uma identidade cultural, haja vista que cada artigo produzido guarda um valor simbólico, conforme destaca Tyszler (2002).

Muitos artistas utilizam as manifestações culturais e sociais que cercam sua realidade, na produção de artigos artesanais representativos. Em outras palavras, é por meio da atividade produtiva que os/as empreendedores/as expressam sua arte como forma de resistência aos problemas sociais, os quais englobam causas que vão desde o empoderamento feminino, passando pela luta contra o racismo até a luta LGBTq+, sendo ultrapassada a visão mercantilizadora de somente obter o lucro financeiro, permitindo, portanto, aos artesãos oportunidade de difusão de conhecimentos e apoio às causas sociais contemporâneas.

\section{METODOLOGIA}

Com o intuito de analisar os fatos que norteiam a prática das artesãs na COOPEART Poti e suas dinâmicas sociais na cooperativa, foi necessária uma aproximação, a qual se deu por meio da pesquisa de campo.

A pesquisa de campo é o tipo de pesquisa que pretende buscar a informação diretamente com a população pesquisada. Ela exige do pesquisador um encontro mais direto. Nesse caso, o pesquisador precisa ir ao espaço onde o fenômeno ocorre, ou ocorreu e reunir um conjunto de informações a serem documentadas. (GONSALVES, 2001, p. 67)

Esta abordagem de pesquisa possibilitou uma confluência de ideias teóricas acerca das temáticas abordadas, sustentabilidade e empreendedorismo social, com a realidade vivenciada pelas mulheres 
membro da COOPERART-Poti e a partir dessa ida ao campo de estudo foi possível tirar conclusões mais relevantes para a pesquisa em questão.

No que concerne ao caráter da pesquisa, foi empregado a pesquisa exploratório-descritiva, com o objetivo de compreender e analisar as relações de trabalho das mulheres da COOPERART e conhecer seu cotidiano como empreendedoras sociais. Partindo do intuito de aprofundar a discussão acerca do processo criativo das artesãs da cooperativa, que se baseiam nas suas crenças e identidade local, bem como o fortalecimento do seu protagonismo frente às dinâmicas sociais e econômicas que cercam a COOPERART-Poti, a pesquisa teve uma abordagem qualitativa.

O método empregado para a investigação foi o materialismo histórico dialético, o qual, de acordo com Foss (2018, s/p), "considera que mudanças sociais só são explicadas quando entendemos o determinado tempo histórico em que o homem viveu e organizou ali suas necessidades, entendendo a organização política e as ideias dominantes de sua época", considerando que as temáticas abordadas neste estudo são conceitos e ideias que passaram por transformações causando alterações na totalidade histórica dos sujeitos envolvidos.

Quanto à coleta de dados, foram realizadas entrevistas semiestruturadas com roteiro elaborado previamente, mas com abertura para novos questionamentos. As entrevistas foram realizadas durante o curso da pesquisa, com garantia do sigilo e privacidade de cada indivíduo entrevistado. A coleta das entrevistas se deu a partir do total consentimento sobre o uso das informações coletadas. Assim, antes da realização das abordagens foi apresentado a cada cooperada de forma oral e escrita o Termo de Consentimento Livre e Esclarecido - TCLE, em cumprimento à Resolução 510 de 7 de abril de 2016 do Conselho Nacional de Saúde.

Faz-se importante destacar que o Termo de Consentimento Livre e Esclarecido é composto pelos objetivos, no qual se propõe a pesquisa de campo, contemplando a relação pesquisador-participante e suas respectivas finalidades. 0 pesquisador informou, com base no referido Termo que as entrevistadas poderiam abdicar de sua participação em qualquer fase da pesquisa, sem penalizações posteriores. Também foi detalhado o zelo pela confidencialidade dos depoimentos obtidos e também a possibilidade de o pesquisador solicitar novas informações às entrevistadas. Assim, o TCLE foi disponibilizado em duas vias, sendo uma delas para usufruto das entrevistadas e a outra permanecerá com o pesquisador pelo período de 3 a 5 anos.

Foram convidadas seis artesãs da COOPEART- Poti para contribuir com a pesquisa. Referente aos critérios de seleção do público entrevistado, levou-se em conta a condição das entrevistadas como membro ativo da cooperativa e o tempo em que estão na COOPEART- Poti (mínimo de 3 anos para participar da pesquisa).

Quanto aos dados e depoimentos coletados, estes foram catalogados e analisados por meio de uma análise sistêmica do conteúdo. Utilizou-se tal prática metodológica na pesquisa para entender os depoimentos coletados por meio do processo de comunicação pesquisador - pesquisado, pois se construíram as categorias de análise para resolver o problema de pesquisa em questão e, por conseguinte, contemplar os objetivos do presente estudo.

Desta feita, a análise de conteúdo será a etapa que o pesquisador compreenderá, por meio dos dados obtidos as complexidades dos sujeitos e da comunidade, analisando suas subjetividades a partir de crenças, papéis sociais e culturais das pessoas e do lugar.

\section{ANÁLISE ACERCA DO TRABALHO DAS MULHERES MEMBRAS DA COOPERATIVA DE MULHERES ARTESÃS DO POTI VELHO (COOPERART- POTI) EM TERESINA-PIAUÍ}

A Cooperativa de Mulheres Artesãs do Poti Velho localizada no bairro Poti Velho em Teresina-Piauí, abrange atualmente 39 artesãs, possui uma sede própria que abriga um espaço de exposição e comercialização dos produtos confeccionados pelas artesãs da cooperativa.

Durante o processo de coleta de dados, que foi conduzido a partir de entrevistas baseadas no do trabalho das mulheres membro da COOPEART-Poti, foram entrevistadas 5 (cinco) artesãs. 0 sigilo das falas das participantes foi garantido, sendo escolhido por elas para representá-las o termo "Artesã" como forma de identificação das falas, numeradas de 1 (um) à 5 (cinco).

No processo de coleta de dados, foram identificadas três macro categorias analíticas, sendo elas: "Significação da COOPEART-Poti"; "Desafios de ser artesã em Teresina-Piauí" e "COOPEART-Poti e sustentabilidade". 
No tocante à categoria "Significação da COOPERART-Poti", a referida cooperativa em seus 14 anos de existência, a instituição se mostra como um importante ganho para as cooperadas e para a comunidade do bairro Poti Velho, pois contribui com o desenvolvimento econômico, emancipação e valorização social das mulheres do Poti e a ocupação em um espaço que até antes da sua fundação, era dominado quase que exclusivamente por homens. Em um primeiro momento, questionou-se às artesãs quando e como essas começaram a trabalhar com artesanato e quais foram os principais motivos que levaram as cooperadas a trabalhar com tal empreendimento.

Comecei em 1965 [...] eu trabalhava nesse tempo vendendo lanches para os artesãos, só que eu me interessei pela pintura, aí eu pedi uma delas para me dar uma aula de pintura e dali eu comecei a comprar peças com os artesãos, comecei a pintar daí, foi que iniciei minha atividade depois já botei um torno já começamos a produzir e até hoje. 0 principal motivo, no primeiro momento, foi a questão da própria necessidade, por eu ser mãe solteira e tinha dois filhos, entendeu, e não tinha outra fonte de renda que não fosse vender o lanche né, [...]. (ARTESÃ 1)

Comecei a trabalhar em primeiro lugar por necessidade, eu tinha filho pequeno e eu precisava ter uma renda para ajudar dentro de casa [...]. (ARTESÃ 5)

As falas das artesãs evidenciam a necessidade por renda, onde as falas entram em consenso com as razões para buscar um empreendimento propostas por Julien (2010), que é a busca por independência financeira e confirmam as afirmações de Barbosa et. al (2011) que coloca o empreendedorismo como forma de alavancar a participação feminina no mercado de trabalho.

Considerando as teorias dos autores citados acima e as narrativas das artesãs, nota-se que a motivação para empreender na comercialização das peças de artesanato é a geração de renda para o sustento da família e melhoria no orçamento familiar.

Muitas das artesãs, quando perguntadas se sobrevivem exclusivamente da renda da cooperativa, responderam que não, como são os casos das Artesãs 1, 2, e 5 que a partir dos rendimentos, investiram no seu próprio empreendimento, abrindo sua própria loja de peças em cerâmica e o comercio de variedades, e afirmam também que antes sobreviviam das vendas na cooperativa e o hoje o dinheiro obtido é para complementar a renda.

Em termos sociais, a cooperativa contribuiu para o reconhecimento da mulher para além das atividades domésticas, a sua significação social, além de uma profissionalização e aperfeiçoamento das suas práticas voltadas ao oficio de artesã por meio de cursos e o incentivo ao empreendedorismo, conforme os relatos das artesãs 1 e 3 :

[...] a cooperativa veio para fortalecer mais isso da geração da renda [...] e esse reconhecimento da profissão dentro e fora do Estado. Através da cooperativa, eu posso te afirmar que foi o reconhecimento da minha profissão [...] dentro da cooperativa eu fui mais reconhecida como profissional sabe, a que sempre se destacou como mulher e além de ser mulher ainda tive que puxar outras mulheres para esta atividade entendeu foi onde a gente foi reconhecida realmente como artesão como ceramista certo. (ARTESÃ 1)

[...] eu entrei aqui na cooperativa, sabia de nada, aí fiz 3 cursos modelagem para saber mexer com a argila, bijuteria e o outro curso, aprender a vender [...] de empreendedorismo né, como lidar com as vendas. [...] antes ninguém me conhecia, eu era a simples dona de casa, e hoje muitas pessoas me conhecem, é no Sebrae, na SESCOOPI [...], tem gente que chega já reconhece logo, então não sou aquela que era só dona de casa, hoje eu sou a artesã da COOPEART-Poti [...]. (ARTESÃ 3)

O ingresso da mulher no mundo do trabalho é um marco na construção sócio-histórica do papel da mesma. 0 protagonismo social demonstrado nas entrevistas pelas artesãs corrobora com o pensamento de Teixeira (2009) a respeito do rompimento da visão "mulher do lar" onde a mulher passa a ser reconhecida como ocupante dos espaços públicos e passam a desempenhar atividades laborais afora dos afazeres domésticos. 
É certo afirmar que a cooperativa em estudo colaborou em diversas frentes na vida social e econômica da mulher. Quando perguntada acerca das contribuições que o trabalho na COOPERART-Poti proporcionou para as artesãs, obteve-se as seguinte resposta "Ela já me deu, é, essa autonomia, me sentir mais viva, me sentir assim útil, [...] porque é muito bom e muito gratificante ver que tá sendo reconhecida [...] é muito gratificante tá aqui." (ARTESÃ 3)

Analisando o depoimento da artesã 3, o desempenho das atividades na produção de artesanato em cerâmica na cooperativa contribui para a valorização da autoestima das mulheres membras, evidenciando o ponto forte e diferencial de se empreender, se configurando como um empreendimento voltado também aos aspectos sociais, indo além da obtenção de renda. Bastos et al (2013, s/p) afirmam que essa modalidade de empreender socialmente em

[...] seu objetivo final não se limita à geração de lucro, tendo uma preocupação central nos aspectos e impactos sociais de sua ação. 0 empreendedor social pode ser caracterizado como [...] agentes de mudança social que "adotam uma missão de gerar e manter valor social."

Mediante a fala e a citação dos autores acima, pode-se afirmar que a COOPEART perpassa a ideia de empreendedorismo comum, tradicional com vistas apenas para o mercado, a modalidade empregada na referida cooperativa busca não só a comercialização dos produtos, mas também criar condições para a melhoria na qualidade vida e bem estar psicossocial das suas cooperadas, sendo uma válvula propulsora de transformações sociais.

As falas anteriores refletem um desenvolvimento sócio material especialmente das cooperadas, a partir de sua profissionalização, na qual ocorrera por meio do artesanato, o que merece análise pelo fato de Teresina não ser uma cidade de potencial para tal área. Desta feita, a segunda macro categoria identificada foi "Desafios de ser artesã em Teresina-Piauí", onde as cooperadas narraram a experiência de viver a dupla jornada conciliar o ambiente doméstico com o mundo do trabalho.

Na COOPEART, foi possível identificar que a tentativa conciliatória desta dupla jornada de trabalho é um desafio para algumas artesãs. Para tanto, quando perguntadas acerca dos desafios de ser artesã, a Artesã 1 respondeu que "Teve um total desafio desde o momento em que entrei até hoje [...], eu tinha dois filhos de menor e mãe solteira e tinha que ajustar essa questão de cuidar da casa e tentar buscar essa questão da geração de renda.". Nesta questão, a Artesã 2 também afirma ter dificuldade "[...] eu tenho que dividir o trabalho de casa com o daqui (o companheiro), o meu artesanato eu faço mais em casa, mas eu venho pra cá fazer os cursos e os plantões."

Nota-se, a partir dos depoimentos acima, que a divisão das tarefas do lar ainda não é bem assimilada, especialmente por homens, sendo atribuídas quase sempre de forma única e exclusiva à reponsabilidade da mulher. Desta feita, considerando os dados da PNAD de 2017, as taxas de realização de afazeres domésticos entre homens e mulheres eram de $76,4 \%$ e $91,7 \%$, respectivamente, refletindo numa sobrecarga de trabalho duplicado dentro e fora de casa para a mulher.

As artesãs relatam ainda que a criação da cooperativa foi um fato decisivo que as ajudou na conciliação das tarefas. Assim, quando indagadas se a COOPEART as ajudou nesse desafio, a Artesã 1 afirmou "aqui foi muito decisivo sabe [...] porque dava pra trabalhar em casa ou perto, e eu acompanho meus filhos na escola e cuidava da casa também".

A parceria de instituições sociais que ofertam suporte na profissionalização das artesãs da cooperativa é algo constante nas entrevistas. Instituições como Sebrae e Fundação Wall Ferraz prestam auxílio no desenvolvimento de novas peças e ofertas de cursos desde a fundação da COOPEART, atribuindo qualificação para as profissionais e valor às peças produzidas.

A Artesã 3 afirma que por meio da cooperativa, os órgãos parceiros as ajudaram nos desafios citados no excerto acima. Para tanto, elas responderam que:

Sim, ela sempre ajuda, a COOPEART, porque a COOPEART sempre tem os órgãos que dão apoio pra nós, como Sebrae sempre tá trazendo novas ideias com cursos e peças para dar aquele apoio, também a Fundação Wall Ferraz né, então esses apoios que a gente ganha dos órgãos para tá renovando isso é muito bom para gente. (ARTESÃ 3).

A partir dos desafios de inovar e trazer algo que representasse a superação, identidade e a realidade local da comunidade do Poti Velho foi que surgiu a coleção "Mulheres do Poti Velho" refletindo de forma simbólica as lutas, as origens das artesãs, sua religiosidade e os aspectos culturais que as cercam. 
Logo, é possível afirmar que a COOPEART-Poti possibilitou às artesãs a superação dos desafios que cercam a prática do artesanato, fortalecendo o reconhecimento da mulher neste espaço ocupacional e explorando as potencialidades do artesanato representativo e a sua consolidação no Polo Cerâmico do Poti Velho em Teresina.

Contudo, durante a condução das entrevistas foi possível observar que a COOPEART-Poti vive situações relativas à questão ambiental, buscando soluções para problemas decorrentes da extração de argila dos leitos do rio Poti e das lagoas ao redor do Poti Velho para confecção dos seus produtos. Trata-se de um esforço ocasionado a partir do dilema entre a necessidade de exploração (mesmo que consciente) da argila e os preceitos de preservação do meio ambiente trabalhados na comunidade. Neste contexto, percebeu-se analiticamente uma outra categoria: "COOPEART-Poti e Sustentabilidade".

Assim, foi perguntando às artesãs sobre as ações da cooperativa em estudo voltadas para sustentabilidade, sendo obtidas as respostas:

[...] a questão ambiental, assim apesar da gente trabalhar com a utilização da argila que é a nossa principal matéria prima que é retirada do meio ambiente, a gente procura trabalhar com mais pecas pequenas para que o consumo de argila na produção também seja bem menor [...]. (ARTESÃ 1)

[...] a gente aqui já estamos adaptando um pouco para o forno elétrico, a gente teve um probleminha com ele, mas já estamos consertando, [...] já tivemos também um fogo a gás para ajudar a não poluir o meio ambiente, aí é assim nós aqui na cooperativa não trabalhamos mais com o fogo a lenha, trabalhamos com o forno elétrico e isso já é uma forma de não poluir o meio ambiente [...]. (ARTESÃ 3)

As ações citadas pelas artesãs são de fato importantes para amenizar os problemas ambientais entre leitos e também a poluição atmosférica. A aquisição de fornos a gás e elétricos pela cooperativa como uma solução para diminuir os impactos na queima da lenha nos fornos tradicionais faz parte de um dos pilares da sustentabilidade que é a responsabilidade ambiental. A mudança no portfólio dos produtos da COOPEART-Poti é uma tentativa de buscar garantir a renovação natural dos recursos extraídos e a redução dos possíveis impactos fruto da exploração na natureza de insumos como a argila. Tais transformações acabam por contemplarem também a dimensão econômica, pois oportunizam maior rentabilidade em termos de lucro financeiro.

Essas mudanças na base de produção das peças artesanais da cooperativa entram em conformidade com os apontamentos sobre as ações voltadas à sustentabilidade de Silva (2008) e Ayres (2008), pois as instituições passam a tentar se adaptar às propostas sustentáveis, frente às demandas ambientais, econômicas e sociais contemporâneas e também pelas modificações do perfil de consumo da população, que influenciam diretamente no padrão de produção dos empreendimentos, onde os consumidores passam a buscar produtos/serviços que em sua produção se preocupam com os impactos de suas ações no meio ambiente.

As entrevistas mostraram também uma preocupação com as dimensões sociais e culturais da sustentabilidade e o perfil de produtos diferenciados que trazem a parte social da cooperativa enquanto empreendimento que manifestam suas tradições em forma de produtos artesanais.

[...] a geração de renda de forma justa do grupo das mulheres, a maioria das mulheres sobrevivi única e exclusivamente daqui da produção e só tem essa ocupação, temos também a questão cultural, entendeu... porque a cooperativa tem um perfil bem diferente do polo na questão da produção [...] A gente tem prioridade em registrar a nossa própria identidade cultural aqui da comunidade do Poti Velho, de Teresina e do Piauí, sempre a gente procura ter esse produto diferenciado levando essa identidade [...]. (ARTESÃ 1)

Concordando com a fala acima, Sachs apud Oliveira (2002) apontam que as empresas, as instituições, os governos e a sociedade devem agir de forma coordenada e planejar ações voltadas à inclusão de renda e tentativa de sanar os problemas ambientais, a questão ecológica e ao crescimento econômico, bem como os aspectos culturais de cada povo ou nação e sua integração. Tyszler (2002) pontua que a produção de arte representativa é importante para o fortalecimento cultural e valorização dos aspectos tradicionais de cada cultura, tendo em vista a carga simbólica que cada produto carrega. 
No tripé da sustentabilidade a dimensão social também é prezada pela COOPEART-Poti. Considerando a fala da Artesã 1 , anteriormente, é notório pensar que a cooperativa é um espaço de ocupação e geração de oportunidades para as mulheres da comunidade sendo uma forma propícia para igualdade social e uma possível solução para alguns problemas sociais como o desemprego. A partir dos novos contornos acerca do termo, é acrescida a parte da valorização e representatividade cultural como ações sustentáveis.

A COOPEART-Poti caminha para se tornar empreendimento sustentável, que por meio do artesanato dar valor humano e cultural para suas cooperadas e comunidade. Porém, as ações buscando a adaptação com meios e métodos menos agressivos ao meio ambiente ainda esbarram em desafios relacionados a conciliação entre os fatores econômicos e ambientais, pela questão da matéria prima, que até então é dependente da extração da argila. 0 relato da Artesã 2 evidencia esse dilema, segundo ela "[...] aqui a gente só pode trabalhar com argila, [...], não podemos trabalhar com madeira, palha... a cooperativa ainda não dá essa permissão para mudar, se a gente mudar, vai produzir como? Então aqui é só argila".

De acordo com Claro e Amâncio (2008) há essa dificuldade por parte dos empreendimentos trazer na prática a sustentabilidade em sua totalidade, sem sobrepor uma dimensão sob a outra. Na cooperativa em questão já existe essa noção e preocupação com a pauta ambientalista, no entanto por se tratar de uma produção em cerâmica a base de argila, ainda tem essa barreira em mudar a matéria prima e aliar todas as dimensões e seguir conforme Elkignton (2001) em uma linha única de resultados baseados em suprir os três pilares da sustentabilidade.

A partir da experiência da COOPEART-Poti é possível notar as tentativas relacionadas a responsabilidade socioambiental e cultural, como a busca por otimizar o uso da a argila evitando desperdícios, passando pela produção e queima das peças por meios ecologicamente corretos, além de outras ações pela comunidade voltadas a preservação do meio ambiente, agregando também os valores culturais. A demanda pelo cumprimento dos padrões sustentáveis é pauta colocada em discursão pelas cooperadas junto aos atores sociais que fazem parceria.

Desta feita, é possível afirmar que a cooperativa deu início a uma transformação no Polo Cerâmico do Poti Velho em Teresina-Piauí, rumo à uma comunidade local ecologicamente correta, justa, com valorização dos indivíduos, voltada para criação de oportunidades e respeito/divulgação das culturas que cercam não só a comunidade, mas também se estendem à toda cidade e estado do Piauí, dada a abrangência de comercialização das peças.

\section{CONCLUSÃO}

0 presente artigo tratou dos impactos do empreendedorismo de cunho social, baseados na experiência de trabalho das mulheres da COOPEART-Poti como forma de geração de renda e emprego e na tentativa de supressão dos problemas socioeconômicos da comunidade Poti Velho em Teresina-Piauí. Foi discutido ainda como as práticas voltadas à sustentabilidade na cooperativa em questão refletem nas dimensões ambiental, social, econômica e cultural da região.

Para tanto, ao longo do trabalho foram discutidos nos itens o papel social da mulher, evidenciando a sua trajetória desde os tempos de submissão em relação ao homem até sua ascensão no mercado de trabalho e sua emancipação. Abordou-se também a questão da diferença entre os termos sustentabilidade e desenvolvimento sustentável e seus conceitos. Ainda buscou-se conceituar os empreendimentos sociais e suas principais características, além de seus impactos no empreendedorismo feminino. Foi discutido também o trabalho das mulheres membro da cooperativa em estudo e as questões que as rodeiam.

Assim, a partir das entrevistam pode-se perceber que uma das principais motivações das entrevistadas adentrarem o mundo do artesanato foi a busca por renda e melhoria na qualidade de vida. Foi possível perceber também que a cooperativa contribuiu para a emancipação das mulheres membro no contexto socioeconômico e valorização social, visto que os desafios acerca do trabalho com artesanato estão na questão de aliar o trabalho doméstico com artesanato, além da necessidade de inovação dos produtos. Neste caso, as cooperadas contam com o apoio da cooperativa e dos órgãos parceiros.

Por meio das entrevistas, foi possível perceber que a cooperativa em estudo fomenta o incentivo à produção consciente e eficiente, com estímulo à criatividade na fabricação e comercialização de artigos de decoração em porcelana e bijuterias, gerando renda e emprego naquela comunidade. É possível afirmar também, que a produção de suas peças representativas sobre a mulher negra, identidade local e religiosidade, acabam por criar condições de autoestima local e bem estar social nos moradores do bairro Poti Velho, além de diminuir os impactos ambientais. Não obstante, ainda no aspecto ambiental, observou- 
se uma preocupação por parte das cooperadas, no que se refere à extração consciente de argila, remetendo a uma lógica de preservação do meio ambiente.

Desta feita, diante de tudo que fora discutido neste material e considerando as narrativas examinadas, fica evidente a COOPEART Poti como um empreendimento promotor de uma melhoria qualidade de vida e autonomia a partir da independência financeira das suas cooperadas, revelando também suas preocupações com o meio ambiente. Dessa forma, é possível afirmar que a cooperativa discutida tem suas funções que vão desde o seu papel social, na promoção de uma comunidade mais justa, até às questões econômicas, as quais envolvem geração de renda e emprego, chegando também à questão ambiental, onde suas ações remetem a esforços de um trabalho sensível à preservação do meio ambiente, numa lógica de exploração consciente dos recursos naturais. Neste intento, sugere-se uma ação conjunta que integre associações e cooperativas que trabalhem com argila e afins, para buscarem desenvolver mais práticas voltadas à preservação dos recursos naturais não renováveis em Teresina.

\section{REFERÊNCIAS}

[1] AYRES, Robert U. Sustainability economics: Where do we stand?. Ecol Econ, v. 67, n. 2, p. 281-310, 2008.

[2] BARBOSA, Felipe Carvalhal et al. Empreendedorismo feminino e estilo de gestão feminina: Estudo de casos múltiplos com empreendedoras na cidade de Aracaju-Sergipe. Revista da Micro e Pequena Empresa, v. 5, n. 2, p. 124$141,2011$.

[3] BASTOS, M. F et al. Redes, empreendedorismo social e negócios inclusivos: em busca de um modelo compreensivo sobre inovação no combate à pobreza na América Latina. In: INTERNATIONAL SOCIETY FOR THIRD SECTOR RESEARCH CONFERENCE, 9, 2013, Santiago de Chile. Proceedings... Baltimore: ISTR, 2013, p. 1-22.

[4] BRUNDTLAND, Gro Harlem; COMUM, Nosso Futuro. Relatório Brundtland. Our Common Future: United Nations, 1987.

[5] CLARO, Danny Pimentel; AMÂNCIO, Robson. Entendendo o conceito de sustentabilidade nas organizações. Revista de Administração-RAUSP, v. 43, n. 4, p. 289-300, 2008.

[6] ELKINGTON, John. Sustentabilidade, canibais com garfo e faca. São Paulo: M. Books do Brasil, p. $20,2012$.

[7] FOSS, Marlon Nantes. As contribuições do materialismo histórico dialético para a pesquisa sobre o programa ensino médio inovador (ProEMI). In: Jornada Brasileira de Educação e Linguagem/Encontro do Profeduc e Profletras/Jornada de Educação de Mato Grosso do Sul, v. 1, n. 1, 2018, Mato Grosso do Sul. Anais. Disponível em: https://anaisonline.uems.br/index.php/jornadaeducacao/article/view/4892. Acesso em: 01 abr. 2020.

[8] FOLADORI, Guillermo. Sustentabilidad ambiental y contradicciones sociales. Ambiente \& Sociedade, n. 5, p. 19-34, 1999.

[9] GONSALVES, E. P. Iniciação à pesquisa científica. 1 ed. Campinas, SP Alinea, 2001. 80 p.

[10] HERCULANO, Selene. Do desenvolvimento (in)suportável à sociedade feliz. In: GOLDENBERG, Mirian (Orgs.). Ecologia, Ciência e Política. Rio de Janeiro: Editora Revan, 1992. p. 9-49.

[11] HOBSBAWM, Eric J. Da revolução industrial inglesa ao imperialismo. 6. ed. Rio de Janeiro: ForenseUniversitária, 2011. 362 p.

[12] INSTITUTO BRASILEIRO DE GEOGRAFIA E ESTATÍSTICA. Pesquisa nacional por amostra de domicílios-PNAD 2015 [Internet]. IBGE, Coordenação de Trabalho e Rendimento. - Rio de Janeiro: IBGE, 2016.

[13] JULIEN, P.A. Empreendedorismo Regional: e a economia do conhecimento. 1. ed. São Paulo: Saraiva, 2010. $400 \mathrm{p}$.

[14] MATOS, Maria Izilda; BORELLI, Andrea. Trabalho. Espaços femininos no mercado produtivo. In: PINSKY, Carla Bassanezi; PEDRO, Joana Maria. Nova história das mulheres no Brasil. São Paulo: Contexto, 2016. p. 126 - 147.

[15] MOLDAN, Bedřich et al. How to understand and measure environmental sustainability: Indicators and targets. Ecol Indic, v. 17, p. 4-13, 2012.

[16] OLIVEIRA, Edson Marques. Empreendedorismo social no Brasil: fundamentos e estratégias. Franca (SP): Faculdade de História, Direito e Serviço Social da Universidade Estadual Paulista, 2004.

[17] PASSOS, Luana; GUEDES, Dyeggo Rocha. Participação feminina no mercado de trabalho e a crise de cuidados da modernidade: conexões diversas. Planejamento e Políticas Públicas, n. 50, 2018. Disponível em: https://www.ipea.gov.br/ppp/index.php/PPP/article/view/847/462 Acesso em: 12 jun. 2020.

[18] ROSOLEN, Talita. Negócios sociais e valores pessoais: Um estudo quantitativo com estudantes de administração. 2014. Tese de Doutorado. Universidade de São Paulo. Disponível em: 
https://teses.usp.br/teses/disponiveis/12/12139/tde-09122014-164116/publico/TatitaRosolenVC.pdf. Acesso em: 01 de abr. 2020.

[19] SACHS, Ignacy. Desenvolvimento sustentável, bio-industrialização descentralizada e novas configurações rural-urbanas: os casos da Índia e do Brasil. In: VIEIRA, Paulo Freire; WEBER, Jacques (Orgs.). Gestão de Recursos Naturais Renováveis e Desenvolvimento - novos desafios para a pesquisa ambiental. São Paulo: Cortez, 2002.

[20] SILVA, Glauce Cerqueira Corrêa da et al. A mulher e sua posição na sociedade: da antiguidade aos dias atuais. Rev. SBPH, Rio de Janeiro, v. 8, n. 2, p. 65-76, dez. 2005 . Disponível em: http://pepsic.bvsalud.org/scielo.php?script=sci_arttext\&pid=S1516-08582005000200006\&lng=pt\&nrm=is. Acesso em: 22 jun. 2020.

[21] SILVA, D. da. Sustentabilidade Corporativa. In: VI Simpósio de Excelência em Gestão e Tecnologia - SEGeT, Resende, RJ, 2009. Anais. Disponível em: www.aedb.br/seget/arquivos/artigos10/31_cons\%20teor\%20bacha.pdf. Acesso em: 15 de mai. de 2020.

[22] TEIXEIRA, Cíntia Maria. As mulheres no mundo do trabalho: ação das mulheres, no setor fabril, para a ocupação e democratização dos espaços público e privado. Psic.: Teor. e Pesq., Brasília, v. 25, n. 2, p. 237-244, jun. 2009. Disponível em: http://www.scielo.br/scielo.php?script=sci_arttext\&pid=S010237722009000200012\&lng=en\&nrm=iso. Acesso em: 22 jun. 2020. https://doi.org/10.1590/S010237722009000200012.

[23] TYSZLER, Marcelo; BARBERO, Edson. Planejamento estratégico em organizações do terceiro setor: o caso do Instituto de Estudos e Orientação à Família. São Paulo: Semead, 2002. 


\section{Capítulo 11}

\section{Responsabilidade empresarial sustentável: Impacto social promovendo sucesso empresarial}

\section{Ari Melo Mariano \\ Caroline Helena Ramos de Queiroz. \\ Fabrício Curvelo Camara Sales \\ Paulo Roberto Cuoco de Melo \\ Camila Rodrigues Lima}

Resumo: 0 presente estudo aborda a prática e atividades de Responsabilidade SócioCorporativa diretamente ligada à Sustentabilidade em relação à promoção do sucesso empresarial, seja em termos de lógica econômica ou valores políticos, sociais, tecnológicos, demográficos ou ambientais. Procura-se demonstrar como a adoção de uma gestão empresarial voltada à sustentabilidade pode colaborar para o crescimento empresarial efetivo e através de um estudo de caso da empresa Coca-Cola evidencia quais fatores que são diferenciais no momento de sensibilizar o cliente para os valores agregados da sustentabilidade. Os resultados foram obtidos a partir de pesquisas na base de dados Scielo e outras fontes disponibilizadas pelo instituto BOVESPA e Relatórios de Sustentabilidades de diversas empresas tomadas como fontes confiáveis. Por meio da análise de dados, constatou-se que há de fato aumentos significativos e válidos quanto à possibilidade de sucesso empresarial quando os investimentos em atividades, práticas ou programas são aliados à gestão empresarial sustentável e à uma boa estratégia de marketing.

Palavras-chave: Sustentabilidade, Responsabilidade Social, Projetos Sociais, Sucesso Empresarial, Vantagem Competitiva 


\section{INTRODUÇÃO}

No século XX a impulsão do desenvolvimento tecnológico fez com que aumentasse não só a expectativa de vida do ser humano, como também sua capacidade de autodestruição. Com o perigo eminente de extinção por conta do esgotamento dos recursos naturais e práticas irresponsáveis, dada a característica de evolução, perpetuação e sobrevivência de todo ser vivo, a humanidade identificou a necessidade de adotar mudanças em sua estrutura para suportar e suprir o crescimento inevitável de sua raça (BELLEN, 2005).

Diante das atuais crises ambientais intrinsecamente ligadas à evolução do sistema capitalista, o desenvolvimento sustentável e à adoção de práticas ecológicas e socialmente responsáveis tornou-se tema eminente das agendas políticas dos Estados, organizações, empresa públicas e privadas e da sociedade civil como um todo. E é comum que haja uma tendência de se estabelecer e enfatizar uma lógica econômica, característica do capitalismo, dentro desse discurso, além da ecológica, cultural, social, tecnológica, demográfica e política, que procuram remeter à razão ambiental através de práticas ecoeficientes do "capitalismo verde", termo aferido por Chico Mendes, que evocado pelo governo do Acre pelo impacto social, político e econômico de seus ideais foi destituído de seu argumento político revolucionário e convertido em pragmático "ambientalista", juntamente com todo o complexo de organizações da sociedade civil que se posiciona em prol da ascensão do desenvolvimento sustentável (ANDRADE DE PAULA, 2013).

Contudo, o desenvolvimento sustentável é definido como um processo de transformação no qual a exploração dos recursos, a direção dos investimentos, a orientação do desenvolvimento tecnológico e a mudança institucional se harmonizam e reforçam o potencial presente e futuro, Com o propósito de atender às necessidades e aspirações humanas, e tem ênfase em satisfazer as necessidades tanto do presente quanto contribuir na preservação da qualidade de vida e bem estar da sociedade de modo a perpetuá-la (CAMARGO, 2003). Entretanto, o surgimento de diversos atores derivados da globalização tem levando este conceito a algumas contradições que divergem na concepção e aplicações das práticas sustentáveis: (...) ao mesmo tempo em que cria limites ao modo de vida, de forma que seja respeitado o meio ambiente, existe a cobrança do crescimento ou maior desenvolvimento para atender as necessidades humanas (...) (JACOBI, 1997).

Estas mesmas necessidades humanas remetem à necessidade vital de conservação do meio ambiente, sendo assim, a simples evocação de lógicas meramente econômicas ignora as múltiplas dimensões da sustentabilidade e direitos adquiridos de democracia e equidade que comportam as necessidades vigentes de difusão de práticas sustentáveis (FLORES, 2013). No modelo capitalista é válido, conveniente e amplamente lógico apelar à racionalidade econômica no tratamento das questões ambientais, pois as empresas foram cultuadas a priorizar seus lucros e investimentos estando sempre atentas às oportunidades de negócio, porém, não somente e inteiramente, pois a mesma pode salientar as desigualdades e dificultar o entendimento real da importância e execução de projetos de governança ambiental em esfera global, como podemos observar, por exemplo, através de experiências com conferências climáticas no âmbito internacional. Experiências essas, tais como a iniciativa de propor a adoção de práticas resultantes na aquisição de créditos de carbono, que se utilizam de maior apelo à lógica econômica.

Ainda neste âmbito, outro importante fator a ser pertinentemente considerado é que nos dias atuais, mesmo em meio a tantas evidências de que a sustentabilidade tenha se tornado prérequisito em meio aos planejamentos de qualquer empresa ou organização, muitas não conseguem de fato comprovar ou evidenciar a dimensão de seus investimentos e comprometimento no setor. Discursão esta reafirmada e aprofundada, por exemplo, em "Responsabilidade Social Corporativa: uma investigação sobre a percepção do consumidor" (FOURNEAU e SERPA, 2007), onde se evidencia ainda um forte debate quanto ao impacto negativo da evidente ausência de interesse e preocupação com o desenvolvimento sustentável por parte das empresas sobre os consumidores, acarretado pela falta de investimentos e comprometimento social por parte dos setores público e privado.

Tendo em vista ser este um tema relativamente recente e de certa forma ainda revolucionário, de modo a apresentar e deferir em prol dos aspectos e vantagens que as empresas podem alcançar no mercado ou em relação aos seus clientes por adotarem ações ambientalmente e socialmente responsáveis, diversos artigos, tais como os já referidos e outro como: "Responsabilidade Social e Investimento Social Privado: Entre o Discurso e a Evidenciação"(MILANI FILHO, 2008); "As Vantagens da Sustentabilidade Empresarial" (GOMES e RAELI, 2010) e "Responsabilidade Social Empresarial: Uma Análise sobre a Correlação entre a Variação do Índice de Sustentabilidade Empresarial (ISE) e o Lucro das Empresas Socialmente Responsáveis que compõem esse Índice" (SOUSA, F. A. de; et. al., 2011), fundamentam seus argumentos respaldando-se 
em pesquisas e bancos de dados como o "Índice de Sustentabilidade Empresarial" (ISE, BM\&FBOVESPA), criado no Brasil no ano de 2005 em parceria com entidades profissionais ligadas ao mercado de capitais, que tem como objetivo identificar os índices de acompanhamento dos mercados fundados, levando em consideração a performance de ações comprometidas com a sustentabilidade, ou seja, "com o atendimento das necessidades e aspirações do presente sem o comprometimento da capacidade de atender às do futuro" (Edemir Pinto, Diretor Presidente da BM\&FBOVESPA).

Com análises de dados tangíveis, fornecidos através de pesquisas eletrônicas, relatórios anuais, balanço social e banco de dados de instituições de pesquisas especializados em análises de investimentos especificamente ligados às praticas sustentáveis que comprovam e proporcionam aos investigadores e interessados leituras detalhadas e análises dinâmicas dos fatos, é possível ponderar que as estratégias empresariais, a rentabilidade e os valores de mercado das empresas privadas e das organizações estão diretamente ligados à adoção de práticas socialmente responsáveis, principalmente no âmbito sustentável, sejam elas no setor privado ou público.

Todavia, para maior respaldo, os referimentos em prol da adoção de práticas sustentáveis e socialmente responsáveis necessitam ainda de maior aprofundamento em estudos de caráter exploratório para deferir, de forma a não restar dúvidas, que a adoção de práticas que direcionam as empresas à atividades de tal caráter, com valores fundamentados na responsabilidade ambiental, ética, econômica e de governança (WODIANER e BACARJI, 2010), estimula a difusão de uma nova cultura entre as empresas e organizações para com seu público alvo e a sociedade de modo geral.

Ademais, é também de grande valia ressaltar que, apesar de ainda não sido tomada como prática obrigatória, em pleno século XXI é essencial, imprescindível e indispensável evolvermos terminantemente para esta consciência sustentável, de modo a aferir maior credenciamento, boa apreciação e conceituada reputação perante a estima crítica dos consumidores, negociantes, parceiros, investidores, governo e sociedade de modo geral.

Sendo assim, tendo em vista que os meios sustentáveis colaboram para o crescimento empresarial efetivo, quais fatores que são diferenciais no momento de sensibilizar o cliente para a sustentabilidade?

Dada a ausência de políticas públicas amplas e relevantes ao mesmo tempo em que a abordagem de sustentabilidade e responsabilidade social faz parte de tanto marketing empresarial, a escolha deste tema se justifica em mostrar que as empresas podem e devem desenvolver ações em contribuição para o desenvolvimento de forma sustentável e socialmente responsável. Seja implementando suas estratégias de gestão socioambiental através de políticas de incentivo ao uso de transporte coletivo, adoção de medidas que contribuam para a redução significativa no uso de descartáveis e materiais de escritório, adaptação da jornada de trabalho a fim de reduzir gastos de energia elétrica, inserção da empresa, funcionários e parceiros em projetos socioambientais, como investimentos na produção de créditos de carbono e projetos socias, ou até mesmo investindo em técnicas e programas de reciclagem, como nos materiais de uso interno da empresa e nos processos de fabricação dos produtos, por ser este um recurso importante para a contribuição da preservação do meio ambiente, entre outras várias alternativas.

Uma vez delimitado o problema da pesquisa e justificada sua relevância, o objetivo inerente deste estudo é identificar os fatores que são diferenciais no momento de sensibilizar o cliente demonstrando/comprovando/justificando a importância e valia da adoção de práticas e atividades que remetam desenvolvimento da empresa à sustentabilidade.

Da sua metodologia, este trabalho foi desenvolvido através de pesquisa exploratória com dados secundários. A realização da pesquisa documental utilizou as seguintes fontes de informação: material disponibilizado por entidades que atribuem índices de sustentabilidade entre empresas e organizações, pesquisas bibliográficas que abordam o tema especificado e artigos científicos.

E para responder ao questionamento quanto aos diferenciais providos pelas práticas sustentáveis em termos de alcance e apreciação de clientes e ainda comprovar o potencial que tais práticas são capazes de agregar no momento de sensibilizar não só o consumidor quanto ao valor social da empresa, mas também destacar para todos os setores de investimentos e serviços os valores que vão muito além das lógicas econômicas que estão intrinsecamente agregados à adoção de atividades e práticas sustentáveis, foi realizada uma pesquisa na base de dados Scielo com as palavras-chaves: Sustentabilidade, Responsabilidade Social, Projetos Sociais, Sucesso Empresarial, Vantagem Competitiva, e foram encontrados 2290 artigos justificando cientificamente o tema.

\section{0 LEGADO DO ÍNDICE DE SUSTENTABILIDADE EMPRESARIAL (ISE)}


O desenvolvimento econômico do país está intimamente relacionado ao bem-estar da sociedade e à busca por empresas socialmente responsáveis, sustentáveis e rentáveis, nas quais seja interessante realizar investimentos. Por isso, uma empresa socialmente responsável é aquela preocupada com o meio ambiente e a comunidade, onde a Responsabilidade Social é muito mais do que uma obrigação com a sociedade. É antes, uma forma de gestão que garante a integridade das operações, certifica a qualidade do produto e, acima de tudo, ratifica a responsabilidade por tudo o que faz.

Tendo a necessidade de compreender e medir e comprovar o comprometimento das empresas com o meio-ambiente e a sociedade, o índice visa oferecer aos investidores o livre acesso a um banco de dados (Figura 1) composto por ações de empresas que apresentam reconhecido comprometimento com a responsabilidade social e a sustentabilidade empresarial. Este é uma ferramenta para análise comparativa da performance das empresas listadas na BOVESPA sob o aspecto da sustentabilidade corporativa, baseada na eficiência econômica, no equilíbrio ambiental, na justiça social e na governança corporativa.

Figura 1: Lista das empresas Elegíveis - Carteira do ISE 2015

\begin{tabular}{|c|c|c|c|}
\hline \multicolumn{4}{|c|}{$\begin{array}{l}\text { USTA DAS EMMPRESAS ELEGIVEIS - CARTEIRA DO ISE } 2015 \\
\text { PERIODD BASE 2014 }\end{array}$} \\
\hline ABC BRASIL & Cosan & ITAUSA & QUALICORP \\
\hline ABRIL EDUCA & CPFL ENERGIA & ITAUUNIBANCO & RAIADROGASIL \\
\hline AES TIETE & CPFL RENOYAV & JBS & RANDON PART \\
\hline AWANSCE & CREMER & JHSSF PART & RODOBENSIMOB \\
\hline AU AMER LAT & CSU CARDSYST & ISL & ROSSI RESID \\
\hline ALPARGATAS & CVC BRASIL & KEPLER WEBER & SABESP \\
\hline ALUPAR & CYRE COM-CCP & KLABIN S/AA & SANEPAR \\
\hline AMBEV S/A & CYRELA REALT & KROTON & SANTANDER BR \\
\hline ANHANGUERA & DASA & LE LIS BLANC & SANTTOS BRP \\
\hline ANIMA & DAYCONAL & LIGHT S/A & SAO CARLOS \\
\hline AREZZOO $\infty$ & DIREGIONAL & LINDX & SAO MARTINHO \\
\hline ARTERIS & DURATEX & LLXLOG & SARANA LNR \\
\hline AUTOMETAL & ECORODOWIAS & LOCALIZA & SER EDUCA \\
\hline B2W DIGITAL & ELETROBRAS & LOCAMERICA & SID NACIONAL \\
\hline BANRISUL & ELETROPAULO & LOG-IN & SIERRABRASIL \\
\hline BBSEGURIDADE & EMBRAER & LOJAS AMERIC & SLC AGRICOLA \\
\hline BEMATECH & ENERGIAS BR & LOJAS MARISA & SMILES \\
\hline BHG & ENEVA & LOJAS RENNER & SOUZA CRUZ \\
\hline BICBANCO & EQUATORIAL & LOPES BRASIL & SUL AMERICA \\
\hline BIOSEV & ESTACIO PART & M.DLASBRANCO & SUZANO PAPEL \\
\hline BMFBOVESPA & ETERNIT & MAEAZZ LUIZA & TAESA \\
\hline BR BROKERS & EUCATEX & MAGNESITA SA & TARPON INY \\
\hline BR INSURANCE & EVEN & MARCOPOLO & TEEHNOS \\
\hline BR MALLS PAR & EZTEC & MARFRIG & TECNISA \\
\hline BR PHARMA & FER HERINGER & METAL LEVE & TEGMA \\
\hline BR PROPERT & FEREASA & MILIS & TELEBRAS \\
\hline BRADESCO & FIBRIA & MINERVA & TELEF BRASIL \\
\hline BRADESPAR & FLEURY & MRV & TEREOS \\
\hline BRASIL & FORIA TAURUS & MULTIPLAN & TIM PART S/A \\
\hline BRASULAGRO & GAFISA & MULTIPLUS & TIME FOR FUN \\
\hline BRASKEMA & GENERALSHOPP & NATURA & TaTVs \\
\hline BRF SA & GERDAU & ODONTOPREY & TRACTEBEL \\
\hline BROOKFIELD & GERDAU MET & O이 & TRAN PAULIST \\
\hline CCRSA & GOL & P.ACUCAR-CBD & TRESUL \\
\hline CEX CAPUAD & GRAZZIOTIN & PANAMMERICANO & TRIUNFO PART \\
\hline CELESC & GRENDENE & PARANA & TUPY \\
\hline CEMIG & GUARARAPES & PARANAPANEMA & ULTRAPAR \\
\hline CESP & HELBOR & PDG REALT & UNICASA \\
\hline CETIP & HYPERMARCAS & PETROBRAS & USIMINAS \\
\hline CIA HERING & IDELASNET & PINE & V-AGRD \\
\hline CIELO & $1 G B S / A$ & PQRTO SEGURO & VALE \\
\hline COELCE & IGUATEMI & PORTOBELLO & VAUD \\
\hline COMGAS & IMC HOLDINGS & POSITIVO INF & VIAYAREIO \\
\hline CONTAX & INDS ROMI & PROFARMA & WEG \\
\hline COPASA & INEPAR & PROYIDENCIA & \\
\hline COPEL & 1OCHP-MAXION & QGEP PART & \\
\hline
\end{tabular}

Fonte: BM\&FBOVESPA, 2014, disponível em: http://www.bmfbovespa.com.br/Indices/download/Listaempresaselegiveis-ao-ISE-2015.pdf

A metodologia do índice foi desenvolvida pelo Centro de Estudos em Sustentabilidade da "Fundação Getúlio Vargas" (FGV-EAESP), o Instituto Ethos, o Ministério do Meio Ambiente e ainda com o apoio financeiro do "International Finance Corporation" (IFC) reunindo inicialmente 28 empresas, e adota o conceito internacional do "Triple Botton Line" (TBL) que avalia, de forma integrada, dimensões 
econômico-financeiras, sociais e ambientais das empresas, acrescido de critérios e indicadores de governança corporativa.

O ISE é hoje benchmark de investidores que querem acompanhar o retorno de empresas preocupadas com sustentabilidade, entre outros fundos de investimento, e desde 2011 é também o índice de referência em negociações na Bolsa de Valores de São Paulo (BOVESPA), além de estimular outras empresas e setores a incorporar questões ambientais, sociais e de governança aos processos de decisão da empresa, tornando o mercado mais atrativo para os investidores em geral e, em particular, para os gestores comprometidos com investimentos socialmente responsáveis (BM\&FBOVESPA).

Figura 2: Evolução Mensal do ISE - Crescimento de 2005 a 2014 (BM\&FBOVESPA, 2014).

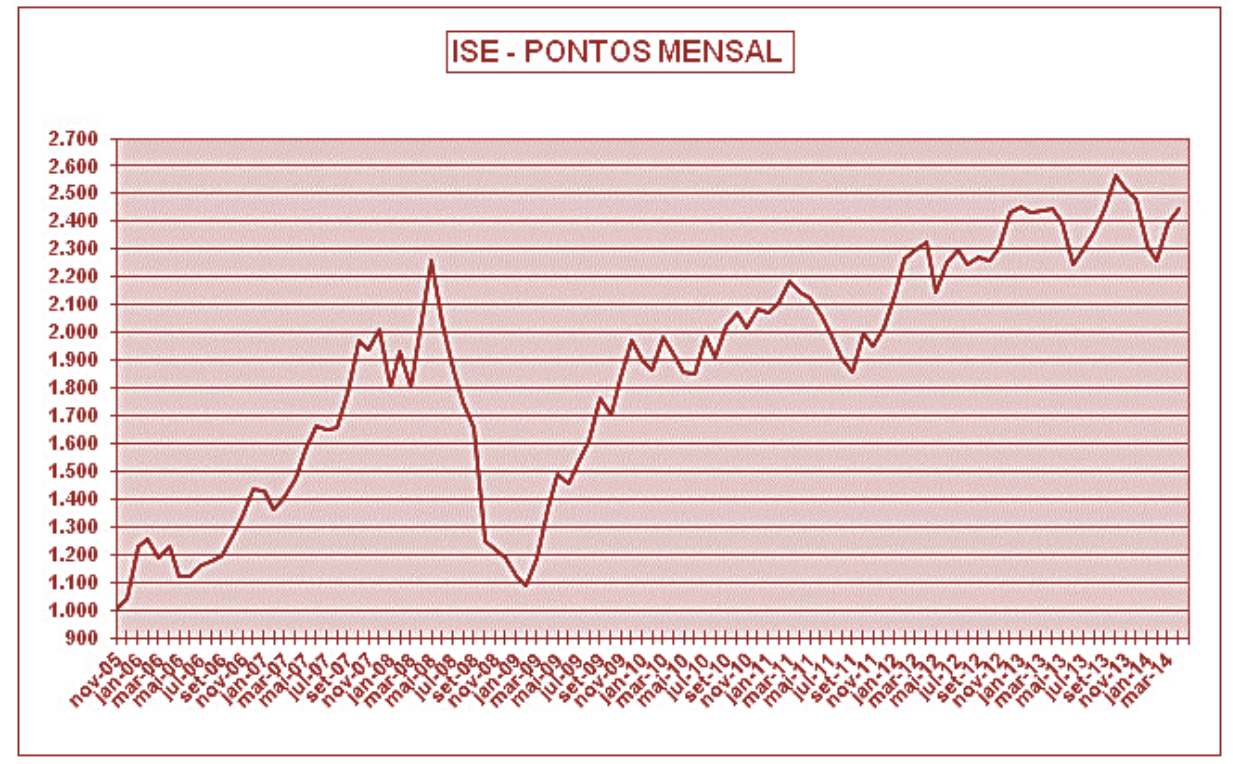

Fonte: http://www.bmfbovespa.com.br/indices/EvolucaoMensal.aspx?Indice=ISE\&idioma=pt-br

Ao longo de sua existência, o ISE vem sendo induzido por um amplo processo colaborativo de participação, pois são as empresas integrantes que contribuem para o aperfeiçoamento da sua organização, contribuindo para o desenvolvimento de uma nova cultura entre as empresas no Brasil e no mundo. Fundamentado em práticas e pesquisas que priorizam a sustentabilidade, o ISE vêm analisando e divulgando dados quanto ao impacto que ações sustentáveis ou não-sustentáveis exercem sobre empresas e organizações em relação à seus clientes, subordinados, entes, agentes e sociedade de modo geral (BM\&FBOVESPA). Comprovando, deste modo, a grande valia de investimentos no setor e assim proporcionando maior esclarecimento sobre os valores agregados às politicas de sustentabilidade e responsabilidade social.

\section{TRIPLE BOTTOM LINE (TBL) - O TRIPÉ DA SUSTENTABILIDADE}

Para efeitos de esclarecimento é pertinente informar que, dentre os vários conceitos de sustentabilidade desenvolvidos a partir dos anos 90 que se utilizam de relatórios corporativos das empresas comprometidas com o desenvolvimento sustentável para medir em termos sociais, ambientais e econômicos os resultados de uma organização, como por exemplo The Natural Step (2000), Capitalismo Natural (Hawken et al., 1999), Teoria dos Capitais (Porritt, 2001; Dyllick e Hockerts, 2002) e Triple Bottom Line (Jhon Elkington,1998; Figura 3), também adotado pelo Índice de Sustentabilidade Empresarial, foi a abordagem preferida para o conceito de sustentabilidade neste estudo, visto que, apesar de ainda apresentar medições de caráter voluntário, além de ser um dos mais amplos e populares, apoia-se na integração de questões sociais, ambientais e econômicas que constitui o tripé do desenvolvimento. 


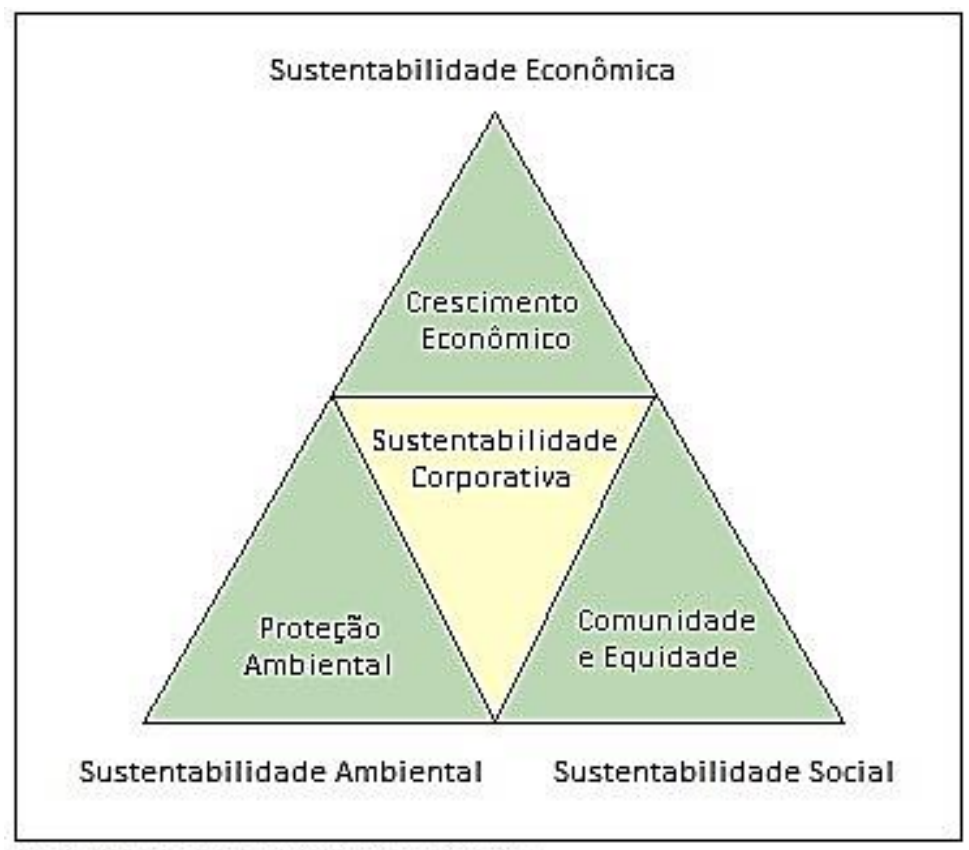

Fonte: J. Elkington apud M. Almeida (2006)

Tal conceito destaca o desenvolvimento sustentável como um processo para alcançar o desenvolvimento humano, de uma maneira segura, igualitária, prudente, inclusiva (HART e MILSTEIN, 2004), e vem sendo objeto de constantes aperfeiçoamentos desde sua criação. Uma empresa sustentável, por conseguinte, é aquela que contribui para o desenvolvimento sustentável ao gerar, simultaneamente, benefícios econômicos, sociais e ambientais, conhecidos como os três pilares sustentáveis (HART, 2004).

O TBL enfatiza os modelos da integração entre os aspectos econômicos, social e ambiental e a integração entre as visões de curto e longo prazo. Sendo o primeiro modelo de integração de curto prazo, defendendo que a ideia de que a sustentabilidade meramente econômica não é suficiente para garantir a sustentabilidade global de uma empresa. Ademais, o modelo de Elkington, quando utilizado para diferenciar as visões de curto e longo prazo, conclui que ambição por lucros imediatos é completamente oposta à sustentabilidade, pois as empresa devem optar pela satisfação das necessidades das gerações atuais bem como, a longo prazo, das futuras, sem prejuízos de qualquer tipo.

Essencialmente, o tripé da sustentabilidade gera uma possibilidade das empresas obterem licenças para operar satisfazendo a seus acionistas, através de lucros e dividendos no tripé econômico, bem como a seus empregados, clientes e sociedade de modo geral, através do melhor desempenho no tripé socioambiental (GOMES, 2000). Em termos estratégicos, esse modelo propõe que, através de uma boa gestão estratégica, as empresas aumentem o desempenho minimizando os impactos econômicos, ambientais e sociais, as empresas possam aumentar seu valor gerando mais oportunidades e reduzindo riscos.

E embora outros modelos também sejam interessantes e apresentem aspectos diretamente relacionados com o contexto social e econômico no qual foram desenvolvidas, as empresas que utilizam do método de Elkington para analisar os resultados de seu tripé perceberam rapidamente que o consumidor tem se tornado cada vez mais responsável e exige ter o conhecimento sobre o impacto econômico, ambiental e social que geram os produtos por ele elegido (MACEDO, 2007).

\section{ANÁLISE PEST-DA EM PROL DO DESENVOLVIMENTO SUSTENTÁVEL}

A inerente importância dos fatores socioambientais e ecológicos na primeira década do século XXI deu origem às práticas sustentáveis, gerando uma necessidade de atualização no enquadramento da "Análise PEST" para "Análise PEST-DA" (acrônimo para uma ferramenta de planejamento estratégico amplamente utilizado na análise das lógicas Política, Econômica, Social, Tecnológica, Demográfica e Ambiental como forças dinâmicas em contínua alteração), trivialmente utilizada na compreensão, avaliação e enquadramento de fatores macro e socioambientais de modo a optimizar a gestão estratégica empresarial. 
Trata-se, portanto, de uma ferramenta estratégica útil e essencial para a análise dos fatores externos que podem influenciar, direta ou indiretamente, a entrada de qualquer empresa no mercado, ou o reposicionamento das existentes, valendo-se de relatórios referentes a diversos fatores macro ambientais que devem ser levados em consideração para uma melhor compreensão do potencial comercial e desempenho do mercado. Portanto, é fundamental que haja uma análise crítica na escolha dos fatores a serem priorizados, de preferência sempre remetendo à razão ambiental, de modo a um balanço social que aprimore o aproveitamento do tempo e recursos de forma eficiente.

O balanço social da empresa deve demonstrar o grau de responsabilidade social assumido, permitindo que os agentes econômicos visualizem e comprovem suas ações beneficentes em programas sociais e investimentos em atividades, práticas e tecnologias sustentáveis que possam prestar contas à sociedade (IUDÍCIBUS; et. al., 2000).

\subsection{ESTUDO DE CASO: "THE COCA-COLA COMPANY"}

Um excelente exemplo de sucesso do enquadramento de fatores ambientais na gestão estratégica é a CocaCola, empresa americana nascida em Atlanta, Geórgia, no ano de 1886. Em 1980 a empresa revolucionou o mercado mundial de bebidas, lançando o refrigerante em lata, em 1988 impulsionou suas ações no mercado com mais uma novidade, as embalagens descartáveis "Oneway", e na década de 90 lançou a lata de alumínio reciclável (thecocacolacompany.com, 2014). E constantemente embalada nas discursões sobre sustentabilidade e preservação ambiental, a empresa foi ainda mais a frente lançado um processo de diversificação de bebidas não carbonadas como água mineral, chá gelado e sucos a base de frutas e em seguida desenvolveu uma garrafa crushable 100\% reciclável com a tecnologia "PlantBottle", na qual até $30 \%$ da matéria tem origem no etanol da cana-de-açúcar, reduzindo em cerca de $20 \%$ as emissões de dióxido de carbono, e produzida ainda através do processo de sopro convencional aliado a uma pré-forma e base diferenciada para garantir a performance mecânica que permite aos consumidores a possibilidade de torcerem as embalagens após o consumo, de modo a reduzir em 37\% seu volume para descarte e facilitar o transporte e armazenamento das garrafas (thecocacolacompany.com, 2014). E muito recentemente, em 2014, a empresa divulgou seu mais novo projeto que visa ampliar ainda mais o uso sustentável de suas garrafas pet, com o projeto "Coca-Cola 2nd lives" (thecocacolacompany.com, 2014), onde a empresa mostra como reaproveitar as garrafas de uma forma criativa, divertida e útil, criando diversas tampas especiais, onde você pode transformar a garrafa num borrifador para regar plantas, diversos brinquedos, dispensador de detergente e shampoo ou até mesmo num apontador de lápis. A empresa, para divulgar o projeto, lançou uma campanha audiovisual divulgada em massa através das redes sociais, onde seu vídeo publicitário que revela o andamento da campanha no Vietnã ultrapassou a marca de 3 milhões de visualizações em pouco menos de um mês após seu lançamento em 15 de março de 2014.

Hoje no Brasil, a empresa detém cerca de $53 \%$ de participação do mercado total de bebidas não alcoólicas prontas para o consumo e $60 \%$ do mercado de refrigerantes, perdendo a liderança somente no mercado de água mineral, atingindo um faturamento anual de $90 \%$ destes setores (MACHADO, L. S.; et. al., ApexBrasil, 2014).

Na análise PEST-DA da emprese observa-se uma crescente preocupação da gestão estratégica em investir e divulgar inúmeros projetos de responsabilidade social e desenvolvimento sustentável. Alguns de seus projetos mais conhecidos são o "Nurture"(institutococacola.org.br, 2014), iniciado na África no ano de 2010 em parceria com a "TechnoServe" e "Bill \& Melinda Gates Foundation", e posteriormente expandido no Haiti, com o objetivo de ensinar aos agricultores como aumentar o rendimento das colheitas, o "Rain" (institutococacola.org.br, 2014) para financiamento de tubos, recipientes e toda a infraestrutura necessária numa iniciativa de reabastecer a África, valendo-se ainda de uma parceria com comunidades locais para o treinamento de agentes que possam ensinar as pessoas como evitar a contaminação da água, o "Coletivo" " (institutococacola.org.br, 2014), projeto que apoia e oferece cursos profissionalizantes, promovendo oportunidades de inclusão e garantia de renda através de subprojetos voltados à cooperativas, mulheres e jovens. E a fim de comprovar a relevância de tais projetos para a sociedade a empresa disponibiliza dados estatísticos e gráficos, tais como os do programa de valorização do jovem apresentados a seguir: 
Tabela 1 -Dados de evasão escolar com o programa da Coca-Cola de valorização do jovem

\begin{tabular}{|llll|}
\hline Ano & taxa de evasão & & \\
1999 & 2,00 & Taxa de evasão & \\
2000 & $2,4 \mid$ & Média & 1,5 \\
2001 & 2,4 & Erro padrão & 0,256196 \\
2002 & 1,9 & Mediana & 1,9 \\
2003 & 2,1 & Modo & 2,4 \\
2004 & 2,1 & Desvio padrão & 0,849706 \\
2005 & 0,7 & Vanância da amostra & 0,722 \\
2006 & 1,6 & Curtose & $-1,09798$ \\
2007 & 0,9 & Assimetria & $-0,6682$ \\
2008 & 0 & Intervalo & 2,4 \\
2009 & 0,4 & Mínimo & 0 \\
& & Máximo & 2,4 \\
& & Soma & 16,5 \\
& & Contagem & 11 \\
& & & \\
\hline
\end{tabular}

Fonte: http://www.institutococacols.org.briprojato-educscso.htm

Gráfico 2 - Evasão escolar com 0 Programa Da Coca-Cola de valorização do jovem

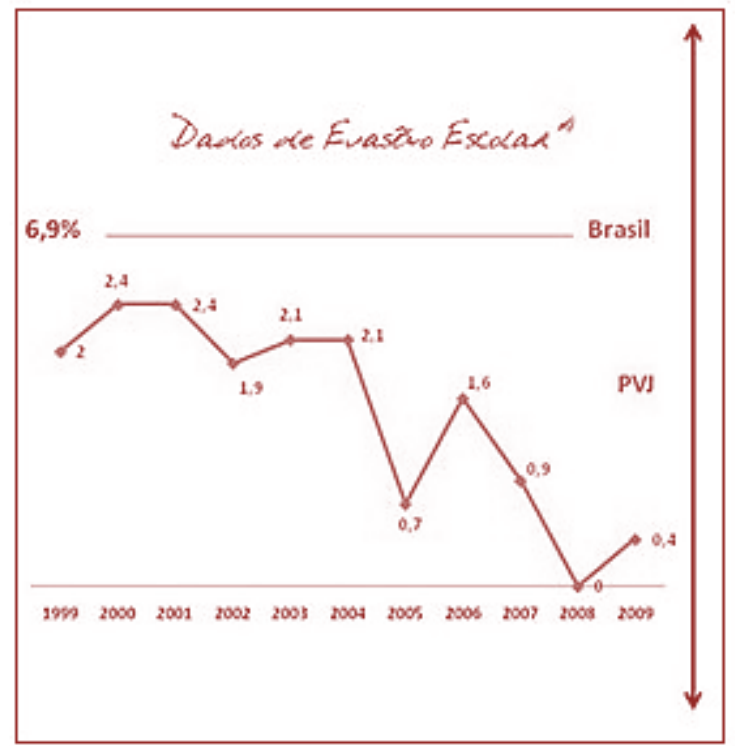

Fonte: http://www.institutococacolg.org.br/projeto-educacso.htm

Esta análise da coca-cola company comprova que o sucesso das empresas está intrinsecamente ligado a seu

caráter socialmente responsável voltado à sustentabilidade. Mesmo atentos às oportunidades de negócios, a empresa mostra-se consciente dos recursos usados e das necessidades dos clientes. E como a Coca-Cola Company, outras empresas nacionais como Oboticário e Banco do Brasil a tempos compreenderam a importância e necessidade de investimentos socialmente responsáveis e sustentáveis, tanto para benefício próprio quanto para seus clientes e a sociedade como um todo.

\section{METODOLOGIA}

Foram realizada duas etapas para alcançar o objetivo deste estudo. 0 primeiro método adotado para este estudo foi o método exploratório através de pesquisa bibliográfica realizada na base de dados scielo onde se encontrou 253 artigos sobre o tema proposto. Também foram consultados relatórios oficiais que 
possuíam informações sobre o tema. Em uma segunda etapa foi utilizado o método qualitativo a exposição do estudo de caso sobre a coca cola.

0 estudo exploratório deu a familiaridade a respeito do tema, enquanto o estudo de caso ajudou a materializar os valores e teorias descritos neste estudo.

\section{CONSIDERAÇÕES FINAIS}

A princípio neste trabalho foi levantado o problema gerado pela impulsão do desenvolvimento tecnológico que fez com que aumentasse não só a expectativa de vida do ser humano, como também sua capacidade de autodestruição, levando a humanidade a identificar que a necessidade de adotar mudanças em sua estrutura para suportar e suprir o crescimento inevitável de sua raça é também. Eminente. A resposta para contornar a situação e retomar o equilíbrio ambiental está não somente em campanhas e propagação de práticas que possam poupar o uso indevido dos recursos naturais e que sejam também menos agressivas ao meioambiente, mas também na adoção de práticas social e sustentavelmente responsáveis partindo primordialmente dos setores públicos e privados. Logo, este trabalho alcança seu objetivo demonstrando a grande valia de investimentos em práticas e atividades não só para atrair clientes, mas também para agregar valores e reduzir os custos. E é comum que muitas empresas abracem esta causa meramente pela lógica econômica e é também possível que muitas se valham de declarações falsas ou não comprovadas quanto à sua gestão ambiental empresarial, minando a credibilidade dada à relevância destas práticas, o que vem a ressaltar uma necessidade de maior fiscalização, estudos e exposição daqueles que de fato contribuem com a restauração e preservação do meio-ambiente e da sociedade, e daqueles que não. Este trabalho fica como contribuição para que futuros pesquisadores estudem possibilidade de realizar futuras pesquisas, , sejam na forma de ensaios em outras empresas ou através de pesquisas de campo, além de implementar os recursos já existentes e atualmente divulgados, de modo a fazer valer a transparência e ética sócio-coorporativa.

Pois na medida em que há um aumento nos índices de adoção de práticas e atividades sustentáveis nas empresas, há também por consequência um aumento da conscientização e entendimento quanto à necessidade de reduzir os gastos e o consumo, destacando para a sociedade a importância das empresas estarem trabalhando com projetos sustentáveis (ABREU, 2007).

A partir desses conceitos observa-se que um dos motivos que leva uma empresa a agir de forma socialmente responsável é se enquadrar nos conceitos de sustentabilidade através de condutas de responsabilidade social que contribuam para o bem estar da humanidade, estimulando atitudes coletivas bem como individuais e promovendo ações que contribuam para a constante melhoria da qualidade de vida e conservação ambiental.

Deste modo, tomando por referência pesquisas bibliográficas e materiais específicos disponibilizados por empresas com perfil socialmente responsável e diretamente ligadas a atividades e práticas que conduzem ao desenvolvimento da sustentabilidade em suas premissas e políticas, comprova-se que sustentabilidade e responsabilidade social são de fato conceitos fundamentais a serem incorporados às estratégias de organizações que almejam atingir seus objetivos e manter crescente seu valor de mercado junto a investidores, consumidores e sociedade. Evidenciando que a sustentabilidade é uma estratégia para criar e conservar valor para as empresas e para a sociedade, sendo necessária uma integração das questões sociais na estratégia e nas operações do negócio, principalmente devido aos seus impactos sobre os elementos intangíveis de valor para uma organização, como imagem, lealdade dos clientes e aval para funcionamento.

Ressaltando que é preciso, contudo, cautela e discernimento para que os projetos de gestão estratégica voltados para questões socioambientais não sejam apenas uma representação teatral da responsabilidade social e do comprometimento com a sustentabilidade que toda empresa deveria ter. Projetos inexistentes, exaltados meramente como modelos de economia verde não praticada, mas que tem por objetivo apenas ludibriar e atrair investidores e consumidores a fim de aumentar o valor econômico de interesse particular. Pois haverá o momento em que a sustentabilidade deixará de ser uma opção ora classificatória para tornarse prática compulsória em todo e qualquer setor de empreendimento no planeta, e os cidadãos do mundo certamente não terão se esquecido daqueles que desde o início se preocuparam não só com os lucros e benefícios próprios, mas que também tiveram grande consideração para com o futuro do meio ambiente e o bem estar de sua sociedade. 


\section{REFERÊNCIAS}

[1] ABREU, Carlos. Você sabe o que é sustentabilidade empresarial?, 2008.

[2] ANDRADE DE PAULA, ELDER. 25 anos depois, Chico Mendes vive mais indignado com o capitalismo verde, 2013. Disponível em: http://reporterbrasil.org.br/2013/12/25-anos-depois-chico-mendes-vive-maisindignado-com-ocapitalismo-verde/ - Acesso em 12/06/2014 às 16:00hrs

[3] BELLEN, Hans Michael van. Indicadores de Sustentabilidade, editora FGV, 1a edição, Rio de Janeiro, 2005.

[4] Carteira do ISE 2014, Lista das Empresas Elegiveis - Período Base 2014 - BMFBOVESPA, 2014. Disponível em: http://www.bmfbovespa.com.br/Indices/download/Lista-empresas-elegiveis-ao-ISE-2015.pdf

[5] CENTRO DE ESTUDOS EM SUSTENTABILIDADE. Fundação Getúlio Vargas. Disponível em: http://ces.fgvsp.br

[6] DYLLICK, T.; HOCKERTS, K. Beyond the business case for corporate sustainability. Business Strategy and the Environment, 2002.

[7] EKLINGTON, J.. Triple Bottom Line Revolution: Report from the Third Millennium . CPA Australia, 1999.

[8] FOURNEAU; SERPA. Responsabilidade Social Corporativa, 2007

[9] GOMES, Silvio Figueiredo; RAELI, André Gomes. As Vantagens da Sustentabilidade Empresarial, 2010 HART, S. A natural resource based view of the firm. Academy of Management Review, 1995.

[10] HAWKEN, P.; LOVINS, A.; LOVINS, L. Capitalismo natural: criando a próxima revolução industrial. São Paulo: Cultrix, 1999.

[11] INSTITUTO BRASILEIRO DE GOVERNANÇA CORPORATIVA (IBGC). Guia de sustentabilidade para as empresas versão para consulta pública. São Paulo, 2007.

[12] INSTITUTO ETHOS. Perguntas freqüentes: o que é responsabilidade social empresarial. 2005.

[13] IUDICIBUS, Sérgio de. Teoria da Contabilidade. 6ํㅜ ed. São Paulo: Editora Atlas, 2000

[14] JACOBI, P. et al. (orgs.). Educação, meio ambiente e cidadania: reflexões e experiências. São Paulo: SMA, 1998.

[15] MACEDO, Luiz Carlos. Responsabilidade Social Empresarial e Sustentabilidade na Cadeia de Valor do

[16] Varejo. Fundação Getúlio Vargas, Escola de Administração de Empresas de São Paulo, 2007

[17] BOVESPA, ISE - Índice de Sustentabilidade Empresarial. Disponível em: http://www.bovespa.com.br MILANI FILHO, Marco Antônio Figueiredo. Responsabilidade social e investimento social privado: entre o discurso e a evidenciação, 2008

[18] PORRITT. Sustentabilidade Corporativa: Análise da Teoria dos Capitais, 2001

[19] Site THE COCA-COLA COMPANY. Disponível em: http://www.coca-colacompany.com/; http://www.cocacola.com/; https://www.youtube.com/watch?v=rWgCQgzJOU4 - Acesso em 13/06/2014 ás 19:30hrs

[20] Site COCA-COLA COMPANY - BRASIL: http://www.cocacolabrasil.com.br/viva-positivamente/razao-de-ser/; http://www.cocacola.com.br/; http://www.cocacolabrasil.com.br/wpcontent/uploads/2013/03/Brazil_200405_Social_Responsibility_Report.pdf. - Acesso em 14/06/2014 ás 09:30hrs.

[21] WODIANER, Adalberto Marcondes; BACARJI, Celso Dobes. ISE - Sustentabilidade no Mercado de Capitais. 1. edição, São Paulo, Report Editora, 2010. 


\section{Capítulo 12}

\section{Aspectos socioeconômicos da agricultura orgânica no estado de Roraima: Um estudo com a Associação Hortivida}

Dayana Machado Rocha

Emerson Clayton Arantes

Resumo: A pesquisa objetivou a descrição histórica de como se iniciou a Associação de Hortifrutigranjeiros Orgânicos de Boa Vista - AHOBV (Hortivida), bem como relatar a experiência adquirida através das visitas a feira para observar qual a dinâmica do local e a interação dos agricultores/feirantes com os consumidores. Assim como evidenciar que os mesmos praticam uma agricultura urbana, pois produzem nas suas residências situadas no município de Boa Vista-RR. 0 presente trabalho objetivou elaborar o perfil dos agricultores e dos consumidores orgânicos do Município de Boa Vista - RR, por meio da caracterização sócio-econômica de ambos. Porquanto, foram aplicados questionários e roteiros de entrevistas aos 07 agricultores pertencentes à Associação de Hortifrutigranjeiros Orgânicos de Boa Vista - AHOBV (Hortivida), bem como, aos 62 consumidores que compravam no estabelecimento durante o período de aplicação dos questionários. A pesquisa se faz relevante, pois a Associação Hortivida é credenciada junto a uma Organização de Controle Social (OCS), na qual, é permitida a venda direta ao consumidor. Assim, concluiu-se que a associação tem caráter ambiental e social importante, pois a mesma dissemina conhecimentos por meio de seminários e minicursos abertos ao público, garante a preservação do meio ambiente e o abastecimento da região com seus produtos que trazem benefícios a saúde. Nesse sentido, espera-se com esse estudo, maiores investimentos públicos de incentivo à agricultura orgânica e a promoção da conscientização ambiental, dos benefícios à saúde e social dos agricultores.

Palavras chave: Agricultura orgânica, produção e consumo. 


\section{INTRODUÇÃO}

O estudo baseia-se na análise do perfil do consumidor e do agricultor orgânico do município de Boa Vista RR. Em virtude disso, estipulou-se uma associação de agricultores orgânicos para a realização da pesquisa com os respectivos ofertantes e demandantes, assim, a pesquisa foi realizada na feira especializada em produtos orgânicos realizada pela Associação de Hortifrutigranjeiros Orgânicos de Boa Vista - AHOBV (HORTIVIDA), habilitada pelo Ministério da Agricultura, Pecuária e Abastecimento-MAPA, na qual pode efetuar venda direta ao consumidor orgânico.

De acordo com o MAPA (2016), a principal característica da produção orgânica é a não-utilização de agrotóxicos, adubos químicos ou substâncias sintéticas que agridam ao meio ambiente (usualmente utilizados em sistemas de produção não ecologicamente corretos). Para ser considerado orgânico, o processo produtivo contempla o uso do solo, da água, do ar e dos demais recursos naturais, respeitando as relações sociais e culturais.

Campanhola e Valarini (2001) presumem que as vantagens da agricultura orgânica, para o pequeno agricultor, ocorrem: pelo processo de policultivo, sendo esse viável em pequenas áreas; pela possibilidade de produção em pequena escala, mas bem diversificada; por atender o mercado local; por empregar toda a família, podendo ainda gerar mais empregos pela exigência de mão-de-obra; mais econômico por utilizar menos insumos externos; por conseguinte não utiliza de agrotóxicos, o que proporciona maior biodiversidade no solo, aumento da nutrição dos alimentos e o aumento da vida útil pós-colheita. Todos esses benefícios são valorizados e compreendidos pelo público consumidor que aceita pagar valores mais altos por esses produtos.

Todavia, o autor também aponta as maiores desvantagens da produção orgânica para os mesmos: dificuldades no estabelecimento de contratos duradouros devido à produção em pequena escala; baixa capacidade gerencial, que dificulta na decisão sobre o que produzir, assim como sobre os mecanismos que devem utilizar para obter maior lucratividade na venda de seus produtos; a falta de assistência técnica e pesquisa científica; dificuldade financeira; dificuldade de acesso ao crédito bancário; custos da certificação; indisponibilidade de mão-de-obra e a falta da mesma com capacitação, inviabilizando a prática em determinadas localidades.

Tendo em vista que a agroecologia engloba diferentes sistemas agrícolas, como agricultura biodinâmica, natural, permacultura, bem como agricultura orgânica que se baseia em uma técnica de produção isenta de insumos artificiais, pois de acordo com a Federação Internacional de Movimentos da Agricultura Orgânica (IFOAM), a agricultura orgânica baseia-se nos princípios da saúde, ecologia, equidade e ambiente. Portanto estudar a Associação (Hortivida) é de fundamental importância para o âmbito Agroecológico, já que a mesma se preocupa em fazer uma agricultura orgânica, visando a proteção do ambiente, saúde da família e dos consumidores em geral. Além de estarem sensibilizando outras pessoas a praticarem esse tipo de agricultura através da sua prática, bem como os seminários e minicursos que oferecem.

A pesquisa foi feita na Associação (Hortivida) que é localizada dentro de Boa Vista - Roraima, a feira onde os produtores vendem o que produzem, em suas casas, fica localizada na Praça AMOCA, e suas respectivas residências ficam localizadas no município de Boa Vista, onde são produzidos os alimentos. Essa pesquisa teve como objetivo entender como a associação foi criada - através de relatos dos associados - de qual forma surgiu o interesse em agricultura orgânica, conhecer o ambiente de plantio e venda desses alimentos, entender como contribuem para o conhecimento acerca do tema para sociedade, assim como entender como isso afeta o estilo de vida desses agricultores.

Desta forma, este trabalho aborda uma economia que é vivida cotidianamente por um grupo de associados, que buscam a valorização de suas práticas ecologicamente corretas e socialmente justas. Com o cultivo consorciado de hortaliças, frutas e a criação de animais. Uma produção de subsistência, basicamente, com um pequeno excedente voltado para o mercado local de um grupo de consumidores esclarecidos e com poder aquisitivo elevado. 0 que caracteriza uma produção de pequena escala, atendendo a um nicho com crescente demanda de alimentos cultivados e coletados sem a inserção de agrotóxicos.

A preocupação com a saúde e o meio ambiente, a busca da qualidade dos produtos, preços, comodidade, segurança, conforto e praticidade são muito importantes e tem influenciado nas escolhas dos consumidores. Diante disso, torna-se importante analisar o instrumento de pesquisa proposto (questionário survey) aos consumidores orgânicos, pois esse conhecimento permite orientar o trabalho de produção, o processo de "marketing" e a comercialização desses produtos. 
Dois tipos de consumidores de produtos orgânicos são apresentados por Darolt (2002). 0 primeiro encontra-se motivado, bem informado e exigente em termos de qualidade biológica do produto. Preferem realizar as compras em feiras verdes ${ }^{4}$, restaurantes e lojas especializadas em produtos orgânicos. 0 outro tipo é o consumidor das grandes redes de supermercados, esse segundo também é bem informado, mas, contudo, não prioriza alimentos in natura como é caso do primeiro consumidor.

Seymour (2005) define padrões de consumo para as classes sociais dos consumidores em geral, pois que, de acordo com esse mesmo autor, nem sempre os níveis educacionais elevados ou o elevado capital econômico são suficientes para garantir que o consumidor tenha as melhores escolhas e hábitos alimentares, mesmo porque, um desacompanhado (condição mais condição cultural) do outro não garante que consumidor possua as condições necessárias para o consumo de alimentos orgânicos. Uma vez que, os consumidores de maior escolaridade podem não possuir de condições econômicas suficientes para saciar seus desejos de consumo, assim como nem sempre aquele que possui elevado capital econômico possui cultura suficiente para distinguir o melhor hábito alimentar. Há ainda, a propaganda influenciando a lei da oferta e da procura, a qual impõe aos mais desprovidos de capital econômico e cultural o consumo de alimentos de baixa (ou quase nenhuma) qualidade nutricional.

Padrões de consumo para Seymour (2005):

Capital econômico elevado e capital cultural baixo: são representados por empregadores, os quais possuem uma alimentação de alto custo, calórica, com ingredientes caros e raros. São pratos complicados de bolos e massas, e que levam basicamente ingredientes enlatados e em conserva;

Capital econômico baixo e capital cultural alto: essa categoria é representada pelos professores, que ao passo de possuir dos conhecimentos, não possuem de renda apta que garanta tal consumo, assim, os mesmos fazem os preparos de seus pratos tradicionais com ingredientes baratos e práticos, coincidindo com uma cozinha original e exótica;

Capital econômico e cultural médio-alto: os profissionais liberais, abastecidos de conhecimento e renda considerável, conseguem manter uma culinária almejada pelos consumidores de capital baixo e cultural alto, assim priorizam o consumo de alimentos leves, de baixa caloria com produtos refinados e saudáveis;

Capital econômico e cultural baixa: e pôr fim a categoria dos funcionários, esses desafortunados de poder aquisitivo ou cultura são induzidos pela estratégia econômica do mercado convencional a consumir alimentos pesados, gordurosos, calóricos e primordialmente mais acessíveis a sua renda.

Em relação aos consumidores, a pesquisa buscou analisar o comportamento dos mesmos de acordo com seus conhecimentos a respeito do sistema de produção orgânico, motivações para o consumo, oferta, divulgação, preços e os hábitos de consumo.

\section{MATERIAIS E MÉTODOS}

A metodologia utilizada foi classificada como de pesquisa qualitativa, por meio de entrevista em profundidade. Para Ramalho (2011, p.102), entrevistas em profundidade "são caracterizadas como entrevistas realizadas de forma direta e pessoal, em que um único respondente é entrevistado individualmente, sendo objetivo do entrevistador, nesse tipo de entrevista, descobrir, entre outros, motivações, crenças e atitudes".

As entrevistas ocorreram de forma individual, em horários preestabelecidos, de manhã e à tarde em seus respectivos locais de produção, no período de 2015. Sendo estruturadas em seis categorias: conversão; associação; produção; entraves; comercialização; reafirmação da escolha. Também foram feitas as observações nos locais e tomado notas para fins de pesquisa. As entrevistas foram realizadas com os 07 membros da associação Hortivida, ocorreram em seus locais de produção, sendo esses, compostos por propriedades periurbanas (quintais de suas casas ou terrenos arrendados). Assim, buscou-se conhecer e apresentar por meio de fotos os modos de vida desses associados e a maneira como produzem os alimentos para a comercialização.

Para a coleta dos dados socioeconômicos utilizou-se do método de pesquisa survey em seu propósito descritivo. Conforme Pinsonnealt \& Kraemer (1993), o instrumento busca identificar quais situações,

\footnotetext{
${ }^{4}$ Cuperschmid e Tavares (2002, p. 06) explicam que "o consumidor verde é aquele indivíduo que procura adotar atitudes e comportamentos de compra coerente com a conservação dos ecossistemas". Exatamente como os princípios do sistema de produção orgânicos estabelecem. Nesse intuito, as feiras verdes representam o canal de obtenção desses produtos ecologicamente corretos.
} 
eventos, atitudes ou opiniões estão manifestos em uma população. Portanto, adaptou-se do modelo do questionário elaborado pela Embrapa (2007) para aplicação com os consumidores. Também se adaptou do questionário elaborado por Barbé (2009), contendo questões abertas e fechadas para aplicação com os produtores de orgânico do município de boa vista - RR.

Ao todo, foram entrevistadas 69 pessoas, sendo, 07 agricultores pertencentes à associação de orgânicos de Boa Vista (HORTIVIDA) e 62 consumidores de orgânicos escolhidos aleatoriamente no ponto de venda realizada na feira da mesma associação pesquisada. Os questionários dos consumidores continham 22 questões de múltipla escolha enquanto dos produtores 18 questões que direcionavam a um roteiro de entrevista.

Foram consideradas como público-alvo as pessoas que se encontravam nas bancas de hortaliças do estabelecimento, efetivamente comprando produtos (FLV- frutas, legumes e verduras) orgânicos. No entanto, não foi possível estimar o quanto tal amostra representa ao universo de consumidores, uma vez que não se conseguiu, no momento da pesquisa, estimar o número total de consumidores que circulava mensalmente no estabelecimento, uma vez que, o período, em que foi realizada a aplicação dos questionários, era um período de férias e muitos dos seus consumidores fieis estavam viajando.

\section{RESULTADOS E DISCUSSÕES}

\subsection{HISTÓRICO DA ASSOCIAÇÃO}

Criada em 29 de julho de 2005 a Associação dos Hortifrutigranjeiros Orgânicos de Boa Vista - AHOBV, sendo essa, uma entidade sem fins lucrativos, de duração indeterminada com sede provisória na travessa Astério Bentes Pimentel, 230, Bairro jardim floresta 1 de Roraima, com o intuito de lutar pela expansão desta atividade orgânica em âmbito local, nacional e internacional. Assim, regida pelo Novo Código Civil Brasileiro, lei $\mathrm{n}^{\circ} 10.406$ de 22 de janeiro de 2002, de acordo com as demais leis vigentes do país e pelo próprio Estatuto social da associação dos hortifrutigranjeiros orgânicos de Boa Vista - AHOBV.

A associação é composta por um presidente, Francisco Canindé e os demais associados distribuídos em cinco homens e uma mulher. Por meio de suas atividades periurbanas ${ }^{5}$, cultivam espécies de origem vegetal como as hortaliças e legumes, frutas das mais variadas espécies e a criação de alguns animais como frangos, porcos, etc. 0 trabalho é feito no decorrer da semana e aos sábados e quartas-feiras, reúnem-se na Praça da Amoca e na avenida Capitão Júlio Bezerra (localizado próximo ao Supermercado Goiana), aonde comercializam sua produção ao ar livre. 0 sistema de produção destes produtores nem sempre ocorreu sobre os preceitos do sistema orgânico, anterior a este sistema a maioria (exceto uma produtora) utilizava dos mecanismos oferecidos pelo sistema convencional. Atraídos para a mudança por questões adversas, bem como apontam os produtores, como problemas com a saúde por uso de agrotóxicos na produção e o desequilíbrio ambiental em que se encontravam suas propriedades por uso de tais insumos químicos.

Dessa forma, tais agricultores fizeram, por três anos, parte da primeira turma do curso de agricultura orgânica oferecido em parceria do SEBRAE, EMBRAPA, prefeitura e outros parceiros institucionais, onde puderam adquirir ensinar e trocar conhecimentos sobre o sistema de produção orgânico tanto na teoria como na prática. Ainda em seu primeiro ano de conversão, os resultados da produção orgânica foram medidos em $\mathrm{R} \$ 325.151,00$, correspondendo em 4,5\% menor em comparação com a atividade convencional exercida anteriormente (AGROECOLOGIA EM REDE, 2016). Nesse projeto foram capacitados 22 produtores com cursos de produção orgânica; associativismo; como vender mais e melhor; processar minimamente hortaliças e visitas técnicas a feiras nacionais. Esse curso está em funcionamento desde então e visa à formação de agricultores em práticas alternativas de produção agrícola com base em uma agricultura sustentável. No entanto, somente nove desses agricultores, capacitados na primeira turma do curso de agricultura orgânica, engajaram-se para a associação. 0 restante se dispersou e a grande maioria ainda trabalha com a agricultura convencional. Como é o caso de três associados, que por questões adversas voltaram a operar com sistema convencional. Em 2012 uma agricultora orgânica, vinda do Rio de Janeiro, conhece a associação e resolve fazer parte da família Hortivida, aumentando o quadro para 07 associados desde então.

\footnotetext{
${ }^{5} \mathrm{O}$ conceito de agricultura urbana ou periurbana trata da atividade agrícola e/ou pecuária praticada nos espaços interurbanos ou periurbanos, estando vinculadas às dinâmicas urbanas ou das regiões metropolitanas (SANTANDREU; LOVO, 2007).
} 


\subsection{CARACTERIZAÇÃO SOCIOECONÔMICA DO AGRICULTOR}

Após as análises dos dados constatou-se que a maioria dos agricultores da associação é do sexo masculino contendo apenas uma associada do sexo feminino. E que destes, apenas um produtor é natural de Roraima, o restante, em sua maioria, pertencia a zona rural do seu estado de origem, assim migrando para o estado de Roraima em busca de novas oportunidades, conforme tabela abaixo.

Tabela 01- Perfil Sócio econômico dos associados da HORTIVIDA - 12/2014

\begin{tabular}{|c|c|c|c|c|c|c|}
\hline Idade & Etnia & Estado civil & Natural & Zona & Grau de ensino & Quant. filhos \\
\hline 52 & Pardo & Casado & PA & Rural & $1^{\circ} \mathrm{Grau}$ & 08 \\
\hline 56 & Branco & Casado & RR & Rural & Técnico & 03 \\
\hline 49 & Branco & Solteiro & RJ & Urbana & $1^{\circ} \mathrm{Grau}$ & 02 \\
\hline 39 & Pardo & Solteiro & MA & Rural & $1^{\circ} \mathrm{Grau}$ & 01 \\
\hline 48 & Pardo & Casado & MA & Rural & $1^{\circ} \mathrm{Grau}$ & 02 \\
\hline 49 & Branco & Solteiro & RJ & Urbana & $3^{\circ} \mathrm{Grau}$ & 02 \\
\hline 56 & Pardo & Casado & RO & Rural & $2^{\circ} \mathrm{Grau}$ & 06 \\
\hline 49 & Pardo & Casado & -- & Rural & $1^{\circ} \mathrm{Grau}$ & 03 \\
\hline
\end{tabular}

Fonte: dezembro de 2014, dados da pesquisa

Os agricultores orgânicos apresentam em média 49 anos de idade e vivem em suas propriedades Periurbanas. As famílias são compostas, em média, 03 filhos e 05 pessoas por família. Com relação à escolaridade, verificou-se que 05 possuem apenas o ensino fundamental incompleto, o restante possui ensino superior. Questionados a respeito da renda mensal da família, 05 responderam que a renda mensal fica na faixa de 03 a 05 salários, os outros 02 afirmam receber valor superior com a comercialização de sua produção orgânica.

Dentre os principais entraves para a produção orgânica, segundo os associados, destaca-se: a falta de mãode-obra qualificada; falta de políticas públicas voltadas para o setor de orgânicos; e as dificuldades em conseguir financiamento que atendam às exigências da produção vigente.

\subsection{RESULTADOS DAS ENTREVISTAS REALIZADAS COM OS ASSOCIADOS, DA HORTIVIDA, ACERCA DO SISTEMA DE PRODUÇÃO ORGÂNICO}

Todos os associados (exceto um) sempre atuaram no campo utilizando dos mecanismos convencionais, e assim, por meio do curso oferecido em 2005 pelo SEBRAE é que eles fizeram a transição da maneira convencional de se produzir para a orgânica. Essa mudança veio de uma série de problemas consequentes do sistema convencional, assim esses motivos podem ser vistos de acordo com essas 05 facetas: problemas com o estabelecimento de produção em desequilíbrio; desejo de mudança; preocupação com a saúde e a natureza; responsabilidade social; satisfação pessoal.

"Porque é um produto limpo, não tem agrotóxico, melhor para a saúde. No passado cheguei a ficar intoxicado com os agrotóxicos". Entrevistado A

Indagados sobre a importância de fazer parte de uma associação reconhecida como orgânica os associados da Hortivida falaram que foi por meio da associação que o grupo fortaleceu nas práticas orgânicas, pois os mesmos tratam de realizar eventos, confraternizações para a promoção das trocas de ideias. Também citam a importância de se ter a associação justamente pelas diversidades locais, dificuldades climáticas. Assim, a entrevistada, ainda trata de compor indivíduos que venham para somar na produção e comercialização orgânica, inserida na associação em 2012.

"A união que o grupo teve em celebrar uma associação, foi o que fortaleceu nas práticas orgânicas. Pois logo que nos organizamos, como associação, passamos a realizar muitos mutirões, onde uma vez por semana, todos se juntavam para realizar uma tarefa na propriedade do outro". Entrevistado B

Dos 07 associados, 05 comercializam sob uma estrutura coletiva devido à falta de volume de produção; pelo reconhecimento de produto superior; contato com cliente; pela união em estar lado a lado com os 
demais associados, compartilhando conhecimentos. Contudo, para os que não comercializam, os principais motivos são: de demanda ainda insipiente, tendo esses que vender sua produção orgânica como produto convencional para restaurantes e assim garantir a venda por inteira de sua produção; seguido das atividades da produção não permitirem realização das atividades produtivas durante as 06 horas de operação das duas feiras, o que prejudica certas culturas como a alface, em que é necessário fazer a rega nesse intervalo de tempo.

"Faço minhas vendas ainda como convencional, uma parte do que eu produzo um associado leva para a feirinha, mas o restante eu vendo como convencional, sem o reconhecimento de produção orgânica, para restaurantes, mercearias. A feira tem a vantagem de poder vender por conta, e a fidelidade dos clientes que frequentam semanalmente a feira de orgânicos, mas ainda falta muita consciência da população em relação a qualidade. Se dependesse só da feira eu não ia me sobreviver aqui, por isso eu optei continuando a vender pelo preço convencional, mas produzido de maneira orgânica". Entrevistado C

Segundo os associados, existe demanda para seus produtos, e essa tem crescido, no entanto, a oferta diversificada não tem sido suficiente. A dificuldade em suprir essa demanda vem da escassez de mão de obra e da dificuldade da continuidade da produção familiar, visto que a maioria dos associados não possui o apoio dos filhos, e alguns deles não possuem cônjuge. Estando essa produção dependente de mão de obra terceira para a obtenção de maiores números de produção. Contudo, os associados afirmaram ter dificuldades em encontrar mão de obra disponível. Para os associados, durante o período de alta produção, o mercado absorve muito produto convencional por este está sendo ofertado em maiores números com preços bem inferiores ao produto orgânico. Assim, quando há escassez do produto convencional o seu preço eleva ao ponto do orgânico e então a procura pelo orgânico cresce a um ponto que a oferta não consegue suprir.

"As vendas oscilam de acordo com o mercado dos convencionais, quando é inverno e os produtores convencionais produzem menos, eu vendo mais. E quando é verão e o mercado convencional está a todo vapor, minhas vendas caem um pouco. Não é o clima que altera minhas vendas, mas a demanda dos clientes que por não serem abastecidos pelos convencionais, abri uma brecha para que os orgânicos tenham mais saída". Entrevistado A

Para os associados o lucro de uma produção orgânica é superior ao da produção convencional, pois apesar dos preços serem semelhantes aos convencionais (preços estabelecidos pelos associados da Hortivida), os gastos com insumos externos são bem inferiores, assim o seu ganho torna-se superior. Assim, os mesmos definem como necessário saber utilizar os recursos disponíveis, que ao longo do tempo a produção tornasse alto sustentável não utilizando mais de recursos externos, isso gera um outro aumento no lucro que passa a não ter mais gastos com insumos externos.

"Muito superior. Porque na agricultura orgânica, a gente chega uma época, que tu acaba fazendo economia. Eu mesmo tô fazendo economia por ano aqui de adubo químico, que de primeiro eu usava, que hoje eu não uso mais. Adubo químico, veneno, essas coisas tudo se chama economia pra mim". Entrevistado D

Diferentes foram os argumentos que os mesmos usaram para justificar a opinião sobre a concorrência. Entende-se que não existe concorrente de produtos orgânicos, ainda que para alguns dos associados essa concorrência se der pelo produto convencional (tal concorrência só os atinge quando a safra é muito boa, o que reduz os preços dos convencionais a um passo que os clientes optam pela economia de tal escolha).

"Concorrência alta. A concorrência é dada pelo produto convencional, nós temos clientes fiéis que não trocam nossos produtos superiores pelo produto convencional, mas não são todos. Falta conscientização da sociedade para diminuir essa concorrência, para o aumento do consumo de alimentos orgânicos". Entrevistado E

"Não tem concorrência. Não tem produção orgânica, só tem produção convencional e eu não considero esse como concorrência por ser um produto inferior". Entrevistado F

Os preços são fixados de acordo com o preço do mercado ou avaliando o custo de produção. Entre os que avaliam o preço conforme o mercado, estão divididas as opiniões entre achar que dessa forma perde e achar que ganha. Alguns associados ao comparar os custos de produção com o de mão de obra e estipular uma porcentagem de lucro, conseguem ter certeza de que realmente estão lucrando, e ainda, conseguem comparar seu preço com o do mercado para identificar se o seu preço estar competitivo com o mesmo.

"A gente vai acompanho o mercado. Mas essa forma não é segura de trabalhar, o certo é fazer um controle, mas a gente não tem esse controle, não tem esse estudo organizado de quanto que ta consumindo tal coisa, 
daí pode ter prejuízo. A gente vai cobrando quando o cliente chia muito, a gente, abaixa o preço e assim a gente vai negociando". Entrevistado $\mathbf{F}$

Segundo a opinião dos associados, a falta de visibilidade do sistema orgânico para a sociedade no geral que ainda é alheia com relação aos benefícios do alimento orgânico tanto para a saúde quanto para a manutenção da agrobiodiversidade, promoção social e cultural dos agricultores. Assim, desorientados, esses clientes não percebem as dificuldades do sistema optando por um produto mais barato, mas que internaliza para a sociedade e ao meio ambiente suas adversidades de produção.

"O maior problema que a gente tem é a questão da falta de visibilidade para a sociedade, do que representa um alimento sem veneno. Temos nossos clientes que são fiéis, mas os clientes que não tem conhecimento quando vem comprar com a gente, não valoriza nosso produto". Entrevistado A

"Se o governo fizesse um trabalho de conscientização nesse sentido, melhoraria muito. Já que o governo interfere e muito no avanço do sistema orgânico, são as burocracias que impõem ao agricultor de comprar os produtos que necessita. Por exemplo, eu importo organismos vivos, mas para que eles cheguem vivos já que são importados de outros estados, é apropriado que venham de avião, no entanto o governo vem proibindo esse canal. O que dificulta ou quase extermina a chegada desses organismos vivos". Entrevistado B

\subsection{CARACTERIZAÇÃO SOCIOECONÔMICA DO CONSUMIDOR DE ORGÂNICOS}

Em Boa Vista - RR, o perfil sócio demográfico dos consumidores de orgânicos foi semelhante àqueles encontrados em estudos similares, realizados com consumidores de alimentos orgânicos (Barbé 2009, Embrapa 2007, Andrade 2012 e Junior 2012). Assim como, os dados dessa pesquisa mostram-se similares também aos dados apresentados pelo relatório de pesquisa do SEBRAE, (2012) "hábitos de consumo em Boa Vista", no qual foi demonstrado que as mulheres comem mais frutas e verduras que os homens, e que uma grande parcela dos consumidores possui renda e nível de escolaridade elevada conforme é apresentado na tabela 02 .

Tabela 02: caracterização socioeconômica do consumidor orgânico do município de Boa Vista

\begin{tabular}{|c|c|c|c|c|c|}
\hline \multirow{2}{*}{ Gênero } & \multicolumn{2}{c}{ Idade } & Estado civil & Escolaridade & Ocupação \\
profissional & Renda familiar \\
\hline Feminino & Até20 anos & Solteiro & Fundamental & Setor público & Até 01salário \\
\hline $58 \%$ & $0 \%$ & $21 \%$ & $6 \%$ & $23 \%$ & $5 \%$ \\
\hline Masculino & De 21 a 35 & Casado & Ensino médio & Setor privado & De 01 a 03 \\
\hline $42 \%$ & $29 \%$ & $68 \%$ & $41 \%$ & $56 \%$ & $12 \%$ \\
\hline & De 36 a 50 & Divorciado & Ensino & Aposentado & De 03 a 05 \\
\hline & $50 \%$ & $8 \%$ & $53 \%$ & $4 \%$ & $20 \%$ \\
\hline & Mais de 50 & Viúvo & & Desempregado & De 05 a 10 \\
\hline & $21 \%$ & $3 \%$ & & $2 \%$ & $22 \%$ \\
\hline & & & & Adm. Do lar & Mais de 10 \\
\hline & & & & $5 \%$ & $22 \%$ \\
\hline
\end{tabular}

Fonte: dezembro de 2015, dados da pesquisa

Os consumidores, aqui pesquisados, encaixam-se no padrão de consumo sugerido por Seymour, (2005), em que os mesmos possuem capital econômico e cultural médio-alto. Para o autor, nem sempre os níveis 
educacionais elevados ou o elevado capital econômico são suficientes para garantir que o consumidor tenha as melhores escolhas e hábitos alimentares, mesmo porque, um desacompanhado do outro não garante que o consumidor possua as condições necessárias para o consumo de alimentos orgânicos.

Em relação ao consumo, são apontados pelos consumidores, como medidas de incentivo necessárias para maior adesão: aumentar a oferta (30\%); melhorar na regularidade da mesma (28\%); aumentando sua diversidade (23\%); deve-se aumentar a divulgação destes alimentos (19\%), abordando sobre os benefícios que os mesmos oferecem, pois ainda há pouca conscientização da comunidade local.

\section{CONSIDERAÇÕES FINAIS}

De acordo com os resultados da pesquisa realizado com o grupo de agricultores orgânicos pertencentes a associação Hortivida. Sendo essa fundada a partir do curso em agricultura orgânica oferecido, pela EMBRAPA em 2005, qual teve ainda em seu primeiro ano de conversão, resultados da produção orgânica medidos em $\mathrm{R} \$ 325.151,00$, correspondendo em 4,5\% menor em comparação com a atividade convencional exercida anteriormente. No entanto, sabe-se que essa redução da receita não representa perda do lucro, uma vez que, o produtor passa a conhecer outras maneiras de utilizar os recursos de sua propriedade, diminuindo assim, custos com insumos externos.

Diante dos dados apresentados e atendendo aos objetivos propostos neste trabalho pode-se concluir que a maioria das pessoas que consomem produtos orgânicos em Boa Vista é do sexo feminino, casadas e possuem idade superior a 35 anos. Em sua maioria os consumidores possuem curso superior e sua renda é superior a 05 salários mínimos. A associação Hortivida vem abastecendo um público consumidor de renda considerada média-alta, por meio do canal "feiras especializadas em produtos orgânicos". Com isso, Feiras especializadas e as feiras livres são os canais mais utilizados para compra dos produtos orgânicos em Boa Vista. 0 meio de informação mais utilizado por estes consumidores são a TV e a internet.

Embora muitos consumidores tenham ouvido falar sobre a produção dos alimentos orgânicos, a maioria vem buscando tais produtos basicamente pelos benefícios para a saúde. 0 que enfatiza maior consciência sobre os benefícios de se consumir produtos orgânicos em contrapartida do desconhecimento do processo de produção e das questões sociais envolvidas. Partindo desse pressuposto, sugere-se que o consumidor pesquisado pode vir a adquirir futuramente por meio de outros canais que não diretamente do produtor, caso haja abertura do mercado por canais de supermercados ou lojas especializadas. Portanto, acredita-se ser de suma importância para a continuidade da produção orgânica local, o incentivo dos produtos locais ofertados pelos produtores da região, como é o caso dos associados da Hortivida, para fins de promoção do consumo solidário, sustentável e soberano.

Conclui-se que a associação perpetua-se ao longo de mais de uma década, por intermédio da união celebrada entre os associados e seus clientes fidelizados, que os acompanham desde o início. União essa que ocorreu por intermédio dos incentivos institucionais que apoiaram a fundação da associação dando visibilidade a mesma com divulgação intensa durante o período de instalação da mesma. No entanto, faltam apoios institucionais que intensifiquem, nesse sentido, mecanismos de forma que possam sensibilizar mais pessoas para que essas venham somar e aumentar nas práticas e no consumo orgânico.

\section{REFERÊNCIAS}

[1] AGROECOLOGIA EM REDE. Associação dos hortifrutigranjeiros orgânicos de boa vista - Hortivida. Disponível em: http://www.agroecologiaemrede.org.br/experiências.php? experiencia=740. Acessado em 06/08/2016.

[2] ANDRADE L. M. S.; Bertoldy M. C. Atitudes e motivações em relação ao consumo ao consumo de alimentos orgânicos. Belo Horizonte: MG, 2012.

[3] BARBÉ, L. C. Caracterização de consumidores e produtores dos produtos BARBOSA, S. C. A. O processo de construção da participação no Conselho Municipal de Desenvolvimento Rural Sustentável no município de Viçosa, MG. 2007. 33 f. Dissertação (Mestrado em Extensão Rural)-Departamento de Economia Rural, Universidade Federal de Viçosa , Viçosa, MG, 2007. agroecológicos/orgânicos. Campos dos Goytacazes -RJ, 2009.

[4] CAMPANHOLA, C.; VALARINI, P. J. A agricultura orgânica e seu potencial para o pequeno agricultor. Cadernos de Ciência \& Tecnologia, Brasília, v.18, n.3, p.69-101, set./dez. 2001.

[5] CUPERSCHMID, N. R. M.; TAVARES, M. C. Atitudes em Relação ao Meio Ambiente e sua Influência no Processo de Compra de Alimentos. RIMAR - Revista Interdisciplinar de Marketing, v.1, n.3, p. 5-14, set./dez. 2002. 
[6] DAROLT, M. R. Agricultura Orgânica: Inventando o futuro. Londrina: Iapar, 2002. DIEHL, Astor Antônio. Pesquisa em ciências sociais aplicadas: métodos e técnicas. São Paulo: Prentice Hall, 2004.

[7] EMBRAPA. Perfil do Consumidor e do Consumo de Produtos Orgânicos noRio Grande do Norte. Aracaju: Sergipe, 2007.

[8] JUNIOR, E. P. A. et al. Aspectos relativos a saúde e ao meio ambiente ligados ao consumo de alimentos orgânicos. Santa Maria: UFSM, 2012.

[9] MAPA. Ministério da Agricultura, Pecuária e abastecimento - MAPA. Produção de orgânicos. Disponível em: http://www.agricultura.gov.br/desenvolvimentosustentavel /organicos acessado em 15/05/2016

[10] PINSONNEAULT, A. \& KRAEMER, K. L. Survey research in management information systems: an assessement. Joumal Management Information System, 1993.

[11] RAMALHO, Aline Dias de Souza. Análise do comportamento do consumidor e do produtor/ comercializador de hortifrutis orgânicos da região metropolitana de belo horizonte. Dissertação de mestrado do curso de Administração da Universidade FUMEC. Belo Horizonte - MG, 2011.

[12] SEBRAE. Serviço Brasileiro de Apoio às Micro e Pequenas Empresas. Hábitos de consumo. Resultado completo da pesquisa“hábitos de consumo em BOA VISTA/RR" - SEBRAE/RR - 2012.

[13] SEYMOUR, D. A construção social do gosto. In: SLOAN, Donald (Org.). Gastronomia, restaurantes e comportamento do consumidor. Barueri, SP: Manole, 2005.

[14] SANTANDREU, Alain; LOVO, Ivana Cristina. Panorama da agricultura urbana e periurbana no Brasil e diretrizes políticas para sua promoção. Belo Horizonte, 2007. 


\title{
Capítulo 13
}

\section{Certificação e produção orgânica no Brasil}

\author{
Guilherme Patricio de Araujo \\ Marta Cristina Marjotta-Maistro \\ Amanda Rezzieri Marchezini
}

Resumo: A busca pela sustentabilidade produtiva visa atender a demanda de consumidores que valorizam processos mais limpos de produção, que evitam a contaminação e degradação ambiental, além de incorporar as populações rurais no processo de desenvolvimento. 0 presente trabalho tem como objetivo analisar o número de produtores, o tipo de certificação destacando a mais utilizada (Auditoria, Organização de Controle Social (OCS) ou Sistema Participativo de Garantia/Organismo Participativo de Avaliação da Conformidade (SPG/OPAC) e quais as culturas mais consumidas e produzidas, ressaltando aquelas que utilizam uma maior área para o cultivo. A pesquisa tem caráter exploratório e quantitativo e os dados utilizados são secundários disponibilizados no site do Ministério de Agricultura, Pecuária e Abastecimento (MAPA Cadastro Nacional de Produtores Orgânicos), além da Pesquisa Nacional sobre o Consumidor de Orgânicos no Brasil realizada pela Organis (2019). Os resultados indicaram que a região Sul do Brasil é a que possui o maior número de propriedades agrícolas orgânicas. Segundo último relatório (2020) do Cadastro Nacional de Produtores Orgânicos, o Brasil possui 21.141 produtores. Sobre a certificação, a grande maioria de propriedades orgânicas da região Norte possui sua certificação por auditoria, na qual garante o selo de certificação; já as propriedades da região Sul se destaca a certificação por meio de OPAC; a região Nordeste do pais é a que possui o maior número de propriedades com certificação via OCS. A cultura orgânica mais produzida é a soja; já as mais consumidas são as frutas. Com esses dados considera-se que: há diferenciação regional em termos da participação da propriedade orgânica e da modalidade de certificação; coexistem produtos orgânicos tanto para abastecimento doméstico como para exportação; a região Sul é a que mais se destaca pelo seu número de produtores orgânicos; pode-se destacar que a certificação tende a ser cada vez maior no setor; e por fim vale destacar que, o mercado de orgânicos é uma área que vem crescendo no cenário nacional, mas que ainda é pouco explorada, como apontada pela sua baixa representatividade no total nacional, possibilitando oportunidade para a capacitação do produtor rural e para a ampliação da produção de orgânicos no Brasil.

Palavras-chave: Orgânicos, certificação, selo, sustentabilidade 


\section{INTRODUÇÃO}

A busca pela sustentabilidade produtiva visa atender a demanda de consumidores que valorizam por processos mais limpos de produção, evita a contaminação e degradação ambiental, além de também incorporar as populações rurais no processo de desenvolvimento, representando a mudança de uma agricultura de insumos para uma agricultura de manejo, visando ser ambientalmente correta, socialmente justa e economicamente viável (MAZZOLENI; NOGUEIRA, 2006).

A agricultura orgânica é o sistema de produção que exclui o uso de fertilizantes sintéticos, agrotóxicos, reguladores de crescimento, organismos geneticamente modificados e preconiza o uso de estercos de animais, rotação de culturas, adubação verde, compostagem e controle biológico de pragas e doenças. Esse sistema de produção está diretamente relacionado ao desenvolvimento rural sustentável, pois traz ao meio rural uma nova prática que privilegia o uso eficiente dos recursos naturais, a manutenção da biodiversidade, a preservação ambiental, bem como a qualidade de vida humana (PENTEADO, 2009).

A transmissão de conhecimento a respeito da produção, realizada por meio da certificação de produtos orgânicos abre grande oportunidade para que esses agricultores incrementem sua renda e melhorarem economicamente suas atividades. Contudo, para que produtos naturais tenham a rotulagem de produtos orgânicos, precisam ser produzidos de acordo com as normas estabelecidas na agricultura orgânica, assim como obter uma certificação que assegure essas condições, o que agrega ainda mais valor ao produto (BORGUINI; TORRES, 2006).

A comercialização de produtos orgânicos sofre com alguns entraves que afetam seu avanço no país, de acordo com Buainaim e Batalha (2007) o crescimento do mercado está relacionado com : descontinuidade na oferta de produtos com a demanda superior à oferta, campanhas promocionais insuficientes de esclarecimento aos diferentes segmentos de mercado, elevados custos de conversão e de certificação, estrutura de crédito deficiente, estrutura de apoio governamental insuficiente, falta de tecnologias com enfoque agroecológico apropriadas aos diferentes agroecossistemas brasileiros, ausência de levantamento sistematizado de informações de mercado, entre outros.

Atualmente, no Brasil, existem três mecanismos para garantir a qualidade do produto orgânico: o controle social na venda direta (OCS), o sistema participativo de garantia (SPG) e a certificação por auditoria (BRASIL, 2009). 0 controle da qualidade orgânica tem como objetivo oferecer à sociedade a garantia de que os produtos foram produzidos de acordo com a legislação para os sistemas de orgânicos de produção. Para os produtos serem comercializados como orgânico deverão obrigatoriamente ser controlado por um desses mecanismos.

Assim sendo, o objetivo deste artigo é dimensionar a produção de orgânicos por região, analisando o número de produtores, o tipo de certificação destacando a mais utilizada (Auditoria, Organização de Controle Social (OCS) ou Sistema Participativo de Garantia/Organismo Participativo de Avaliação da Conformidade (SPG/OPAC) ) e quais as culturas mais consumidas e produzidas, ressaltando aquelas que utilizam uma maior área para o cultivo.

Justifica-se esta pesquisa devido a importância de uma agricultura mais sustentável, e a importância da segurança alimentar baseada na certificação de orgânicos que, por sua vez, traz, ao produtor, uma maior agregação de valor e consequentemente uma maior rentabilidade. Nesse sentido, o entendimento desse tipo de agricultura subsidia a aplicação de políticas públicas que busquem incentivar e/ou valorizar a agricultura orgânica familiar para que então atenda a demanda.

Este artigo está dividido em seis partes, sendo a primeira esta Introdução, seguido pelo

Referencial Teórico utilizado na pesquisa, a Metodologia, a Discussão dos Resultados e a Conclusão, finalizando com as Referências Bibliográficas.

\section{REFERENCIAL TEÓRICO}

\subsection{HISTÓRICO E CONCEITUAÇÃO DE PRODUTOS ORGÂNICOS}

O início da agricultura orgânica foi a década de 1920. Entretanto, ainda não havia padrões referentes à segurança alimentar nem interesse no meio-ambiente. Dos anos de 1930 a 1970 foram fundamentadas as bases da produção orgânica. A partir da década de 1980, devido às mudanças nos hábitos alimentares da população, a fim de buscar uma melhor qualidade de vida, esse tipo de agricultura se fortaleceu (OLIVEIRA; ALMEIDA JÚNIOR, 2008; VILELA et al., 2006). Segundo Arbos et al. (2010), na década de 1990, 
houve um aumento vertiginoso da busca por dietas mais saudáveis, com diminuição nos prejuízos à saúde, o que levou ao aumento do consumo de alimentos orgânicos.

Impulsionadas pelos princípios da sustentabilidade e por pressões sociais, intensificou-se a produção e a procura por produtos orgânicos. Em 1994 o Ministério da Agricultura (MA) foi então procurado por Organizações Não Governamentais (ONG) que propuseram a regulamentação da certificação de produtos orgânicos, o que resultou na Portaria MA no 178 de agosto de 1994 e que criou a Comissão Especial para propor normas de certificação de produtos orgânicos (CAMARGO, 2002).

Em 27 de dezembro de 2007, o Decreto $n^{\circ} 6.323$ (BRASIL, 2007) regulamentou a Lei 10.831 de 2003 (BRASIL, 2003), que apresenta alguns conceitos, diretrizes e disposições gerais sobre as relações de trabalho existentes na atividade da agricultura orgânica, relativas à produção, comercialização, informações sobre a qualidade (identificação, rotulagem e publicidade) e também sobre os insumos. Além disso, regulamenta a atividade de avaliação da conformidade através da certificação dos produtos orgânicos e sua respectiva fiscalização.

Segundo a lei no 10.831, de 23 de Dezembro 2003, art. 1o considera-se sistema orgânico de produção agropecuária todo aquele em que se adotam técnicas específicas, mediante a otimização do uso dos recursos naturais e socioeconômicos disponíveis e o respeito à integridade cultural das comunidades rurais, tendo por objetivo a sustentabilidade econômica e ecológica, a maximização dos benefícios sociais, a minimização da dependência de energia não-renovável, empregando, sempre que possível, métodos culturais, biológicos e mecânicos, em contraposição ao uso de materiais sintéticos, a eliminação do uso de organismos geneticamente modificados e radiações ionizantes, em qualquer fase do processo de produção, processamento, armazenamento, distribuição e comercialização, e a proteção do meio ambiente.

\subsection{CERTIFICAÇÃO DE PRODUTOS ORGÂNICOS}

No Brasil, o produtor orgânico deve fazer parte do Cadastro Nacional de Produtores Orgânicos (MAPA), o que é possível somente se estiver certificado por um dos três mecanismos possíveis. Segundo o Ministério da Agricultura, Pecuária e Abastecimento (MAPA) os tipos de certificação são:

Certificação por Auditoria: quando é feito uma concessão do selo SisOrg por uma certificadora pública ou privada credenciada no MAPA; o organismo de avaliação da conformidade obedece a procedimentos e critérios reconhecidos internacionalmente, além dos requisitos técnicos estabelecidos pela legislação brasileira;

Sistema Participativo de Garantia (SPG): caracterizada pela responsabilidade coletiva dos membros do sistema, que podem ser produtores, consumidores, técnicos e demais interessados; para estar legal, um SPG tem que possuir um Organismo Participativo de Avaliação da Conformidade (OPAC) legalmente constituído, que responderá pela emissão do SisOrg;

O último tipo de certificação é aquele realizado por um Organismo de Controle Social (OCS), onde a legislação brasileira abriu uma exceção na obrigatoriedade de certificação dos produtos orgânicos para a agricultura familiar; exige-se, porém, o credenciamento numa organização de controle social cadastrado em órgão fiscalizador oficial. Com isso, os agricultores familiares passam a fazer parte do Cadastro Nacional de Produtores Orgânicos, que permite a venda direta de produtos orgânicos ao consumidor, onde o próprio grupo é responsável em assegurar que um produto, processo ou serviço atenda aos regulamentos ou normas específicas a que foi submetido. A ideia de criação desse organismo veio da observação de que muitos produtores da região já vinham trabalhando com práticas agroecológicas e sustentáveis respeitando o meio ambiente e o processo produtivo.

\subsection{DESAFIOS NA COMERCIALIZAÇÃO DE PRODUTOS ORGÂNICOS}

A falta de informação do consumidor ainda é um dos entraves para o desenvolvimento da agricultura orgânica. Segundo o especialista Sérgio Carrano da BioBrazil Fair para o site OrganicsNet (2015), um dos fatores que prejudicam a popularização dos produtos orgânicos é a falta de campanhas e políticas de divulgação dos benefícios do setor.

A questão da desconfiança enquanto a esses produtos se perde a partir da certificação de produtos orgânicos, dado que este procedimento assegura que um produto obedeça a determinados requisitos tais 
como, por exemplo, a ausência de agrotóxicos e adubos químicos, ausências de transgênicos. A emissão deste certificado garante que aquele produto é diferente dos demais.

Segundo a ORGANIS (2018) a agricultura orgânica brasileira vem se desenvolvendo a uma taxa de $20 \%$ ao ano, e já tem grande participação no mercado interno, movimentando cerca de $\mathrm{R} \$ 3$ bilhões, sendo considerado entre os setores que mais crescem no Brasil. A demanda pelos produtos orgânicos, que vem crescendo, está relacionada a preocupação e exigência dos consumidores, que buscam por uma qualidade melhor de alimentos e com os impactos ambientais. Alcançar uma vantagem competitiva sustentável é uma busca constante das organizações, com isso a ampliação da agricultura orgânica está atribuída ao desenvolvimento de um mercado socialmente justo para produtores e consumidores, economicamente viável e que é altamente gerador de empregos (MAPA, 2007).

0 aumento do comércio de produtos orgânicos deve ir além das técnicas de produção e da busca por um padrão de qualidade superior, ele também deve ser baseado no estudo e aplicações dos fundamentos do marketing. Dentre algumas ferramentas, o marketing mix (produto, preço, praça e promoção) mostra-se uma poderosa aliada como ferramenta de atuação junto ao mercado consumidor, pois concentra as ações a serem tomadas pelo produtor junto aos quatro principais pilares que irão influenciar na decisão de compra dos consumidores, possibilitando traçar a adoção e o direcionamento de estratégias de marketing, em específico de marketing ambiental ou marketing verde. Segundo Ottman (2013) no "marketing verde", se usam ferramentas mercadológicas que tem como objetivo criar e disponibilizar no mercado produtos que sejam socialmente corretos e ambientalmente responsáveis. 0 termo marketing verde é utilizado também para descrever as estratégias que os profissionais de marketing procuram utilizar objetivando a satisfação do consumidor envolvido com as questões ambientais e sociais (AGRAWAL, 2013; OTTMAN et al., 2006; PEATTIE; CRANE, 2005).

A fim de prever as perspectivas de comportamentos futuros dos consumidores muitos modelos de comportamentos foram criados, o que é o caso do modelo de Blackwell et al. (2005), que permite a distinção e a compreensão das diferentes fases do processo decisório de compra. Para esses autores, o processo decisório de compra é dividido em etapas: (a) Reconhecimento da Necessidade, (b) Busca, (c) Avaliação de Alternativa Pré-Compra, (d) Compra, (e) Consumo e (f) Avaliação Pós-Consumo. As estratégias de marketing verde podem influenciar em todas as etapas do processo de decisão de compra, conscientizando o consumidor dos benefícios dos "produtos verdes" e ajudando-o a reconhecer as necessidades de consumo deste tipo específico de produto, fornecendo informações aos consumidores, facilitando e influenciando seu processo de busca e sua escolha futura, explicitando os benefícios "verdes" do produto, sugerindo maior valor em decorrência dos atributos relativos à sustentabilidade em comparação às demais opções de compra e disponibilizando o produto de maneira atrativa e adequada ao perfil dos "consumidores verdes" e disponibilizando um produto com qualidade esperada, mantendo a preocupação com a experiência de compra e consumo do consumidor desde o uso até o descarte do produto, evidenciando os benefícios "verdes" de todo o processo (AGRAWAL, 2013; BLACKWELL et al., 2005; CRONIN, 2011; GINSBERG; BLOOM, 2004).

Um determinante fator de mensuração de resultados e sucesso é o consumidor final de qualquer produto (NAVA, 2004). Esse diferencial competitivo é baseado no produto e no marketing que ele carrega. Segundo Prata Neves (2001), os produtos orgânicos deverão ampliar sua participação de mercado, graças as novas tendências de consumo alimentar, que na busca por uma vida mais saudável, os consumidores irão cada vez mais sair à procura de alimentos naturais, livres de defensivos agrícolas e outros insumos utilizados na agricultura convencional. Sendo assim, os alimentos orgânicos satisfazem perfeitamente a essa nova tendência. (STRINGHETA e MUNIZ, 2003; O'DONOVAN e MCCARTHY, 2002).

A definição de canis de distribuição do produto é uma das principais estratégias de comercialização, pois é através dela que um produto chegue até seu mercado-alvo, tornando-o disponível para o consumo. Com isso medidas são necessárias para transferir o produto da sua origem e transportá-lo até o destino com o menor prazo e o maior cuidado a fim de evitar desperdícios e perdas (ETZEL; WALKER; STANTON, 2001). A crescente demanda pelos produtos orgânicos, atualmente é incompatível com a oferta, o que representa uma oportunidade para agricultores, onde permite o desenvolvimento de uma agricultura orgânica sustentável, competitiva, capaz de produzir alimentos de alta qualidade durante o ano todo através das condições climáticas e ecológicas favoráveis, sendo economicamente viável ao produtor. 


\section{METODOLOGIA E FONTE DE DADOS}

O artigo será conduzido pela utilização de dados secundários obtidos por meio de revisões bibliográficas, englobando livros, trabalhos acadêmicos, sites de instituições públicas e privadas, entre outras produções existentes na literatura relacionada à área de estudo, sendo uma pesquisa de caráter exploratória. Pode-se citar fontes dos dados: Ministério da Agricultura, Pecuária e Abastecimento (MAPA); Instituto Brasileiro de Geografia e Estatística (IBGE); Associação de Promoção dos Orgânicos (Organis).

A análise será realizada de maneira descritiva/exploratória. De acordo com Gil (2008) as pesquisas exploratórias têm como objetivo desenvolver, esclarecer e modificar conceitos e ideias. Além disso, define a pesquisa descritiva como a descrição das características de determinada população ou fenômeno ou o estabelecimento de relações entre variáveis. São diversos os estudos que podem ser classificados sob esta definição e uma de suas características mais significativas está na utilização de técnicas padronizadas de coleta de dados.

\section{RESULTADOS E DISCUSSÃO}

A partir de 2012, o mercado de orgânicos no Brasil vêm mostrando um notável crescimento, e com a certificação destes produtos trouxe uma maior credibilidade ao segmento. Segundo o Instituto de Pesquisa de Cultura Orgânica e da Federação Internacional de Movimentos da Agricultura Orgânica, desde 2013, o país é considerado como um dos maiores produtores de alimentos orgânicos do mundo, e conforme dados do Conselho Brasileiro da Produção Orgânica e Sustentável (Organis) o faturamento no setor de orgânicos foi de $\mathrm{R} \$ 4,0$ bilhões, em 2018 , o que se mostra sete vezes maior do que o faturamento de $\mathrm{R} \$ 500$ milhões de 2010.

O Brasil conta com mais de 705 mil hectares destinados a agricultura orgânica, de acordo com um levantamento da Federação Internacional de Agricultura Orgânica (2016), o que coloca o país na 10ํㅜ posição no ranking, atrás de países como Itália, EUA, Argentina, dentre outros. O Ministério da Agricultura, Pecuária e Abastecimento (MAPA) possui o cadastro nacional dos produtores orgânicos, onde é possível obter diversas informações sobre produção, certificação, etc. Conforme apontam os resultados na Figura 1 tem-se a participação relativa (em porcentagem) de propriedades orgânicas no montante nacional em 2020.

Figura 1 - Mapa com dados sobre propriedades orgânicas por região

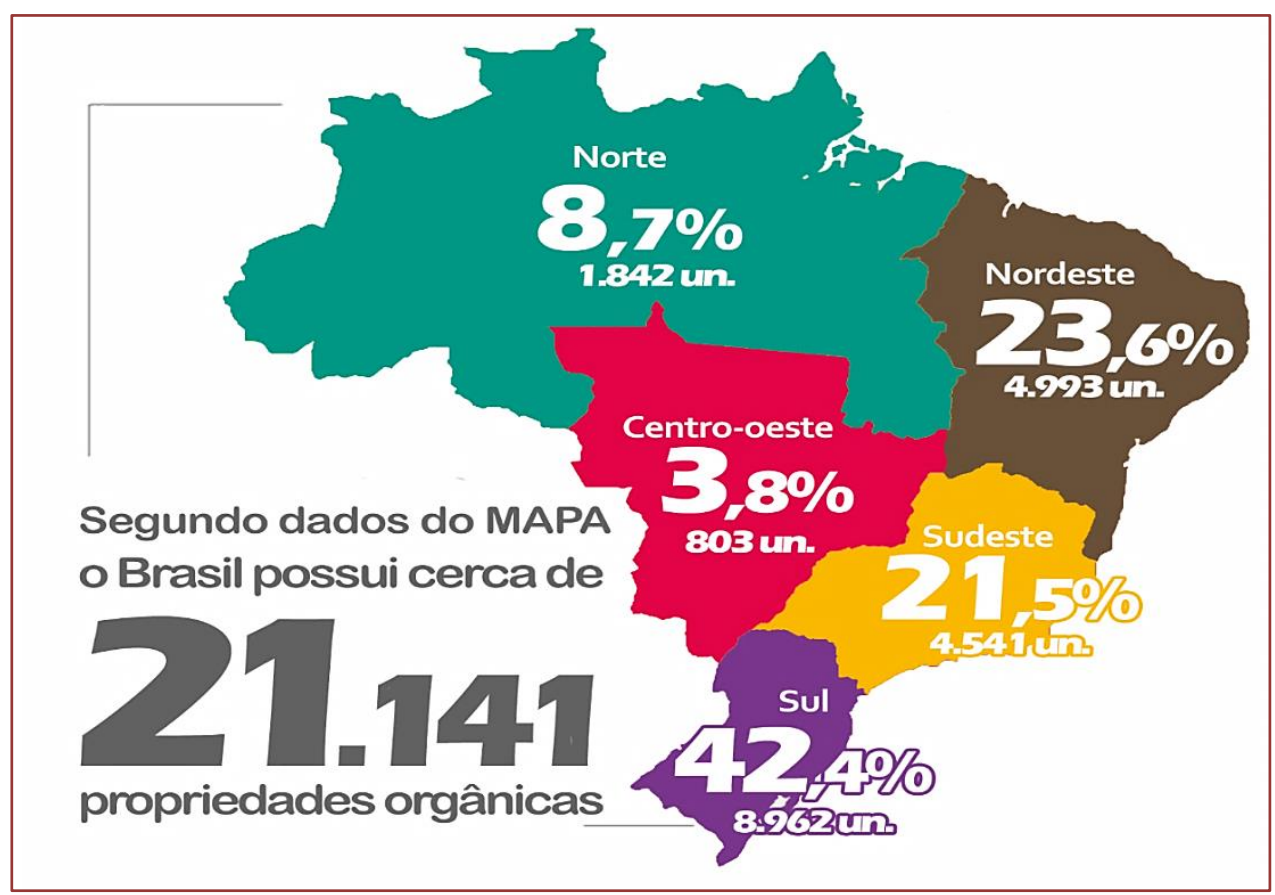


De acordo com dados da Figura 1, a região Sul do Brasil possui 42,4\% de todos os produtores orgânicos do território, sendo uma região muito importante para a produção de orgânicos e, junto com a região Sudeste, possui um importante papel nacional em relação a participação na produção e abastecimento, onde juntos somam 63,9\% e mais de 13.500 produtores. A região Nordeste é muito importante, sendo uma agricultura orgânica familiar de carater de subsistencia e regional, onde representam 23,6\% do total nacional. A região Centro-oeste possui uma agricultura orgânica de monocultura, com a implantação de soja e cana orgânica, segundo dados do MAPA, representando 3,8\% dos produtores nacionais.

A Figura 2 traz a diferenciação da certificação nas regiões do Brasil, sendo quantificadas os três tipos existentes, são eles: Auditoria, OCS e OPAC. Foram analisadas 21.141 propriedades orgânicas que estão no cadastro nacional de produtores orgânicos, subdivididos em suas regiões.

Figura 2 - Quantificação dos tipos de certificação no Brasil - por região

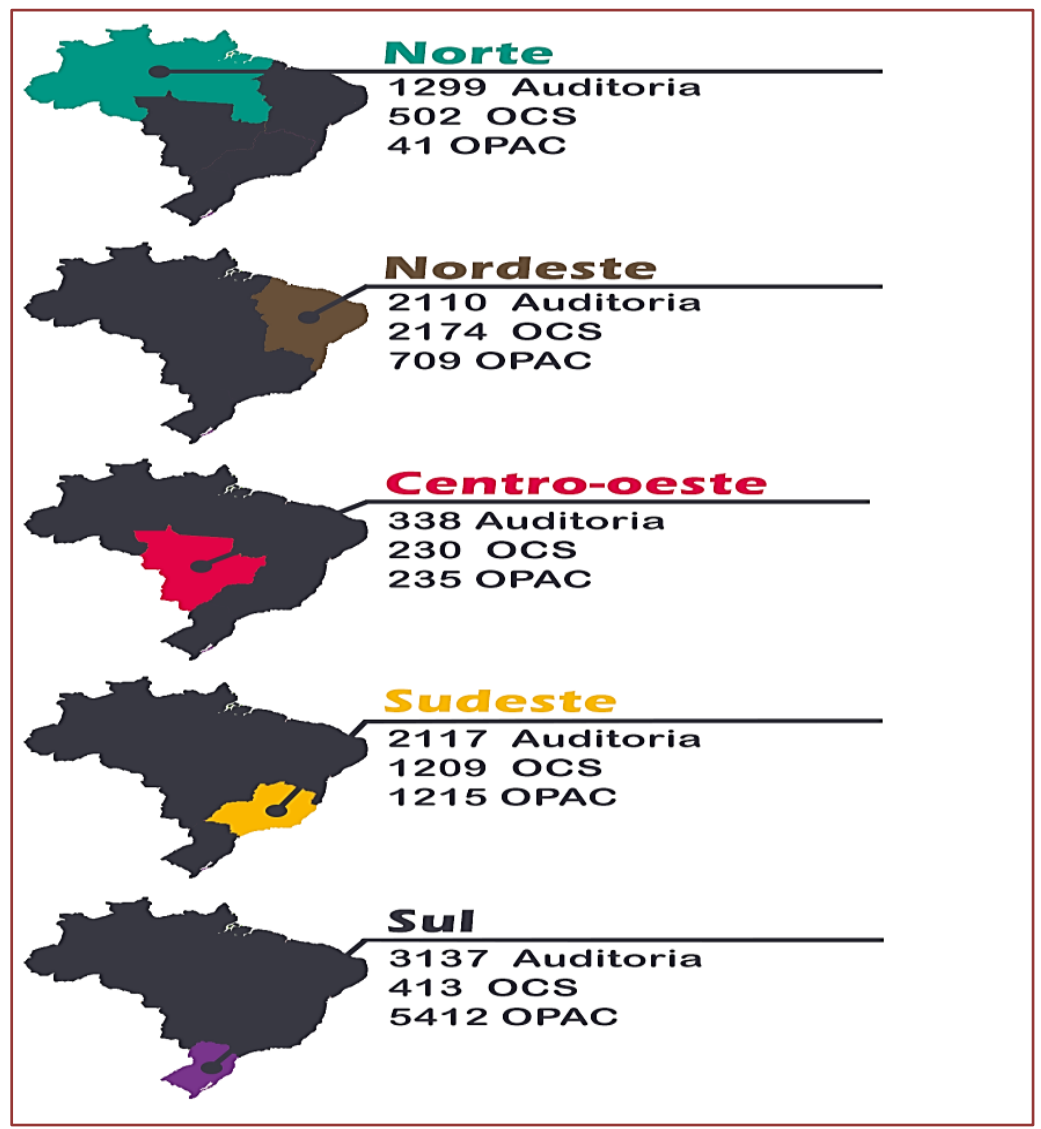

Fonte: MAPA (2020). Elaboração própria

De acordo com a Figura 2, a região Sul se destaca por possuir o maior número de propriedades que possui Organização Participativa de Avaliação da Conformidade (OPAC) como certificação, com cerca de 5412 propriedades cadastradas. Outro tipo de certificação com destaque na região é a pôr certificadora com 3137 propriedades, que possuem o selo de produto orgânico (Figura 3), que pode ser obtido através de uma série de parâmetros exigidos pelo MAPA.

Dos 1842 produtores da região Norte, 70,52\% possui a certificação por auditoria, representando a região brasileira que possui o maior número de propriedades com selo de orgânicos e que segue todos os critérios.

A região Centro-Oeste é a região que possui os valores mais próximos dentre os tipos de certificação existente, onde cerca das 803 unidades produtivas, 42\% é por auditoria, 29\% por OCS e 29\% por OPAC, quando comparados com dados das outras regiões. 
Figura 3 - Selo da certificação orgânica por auditoria

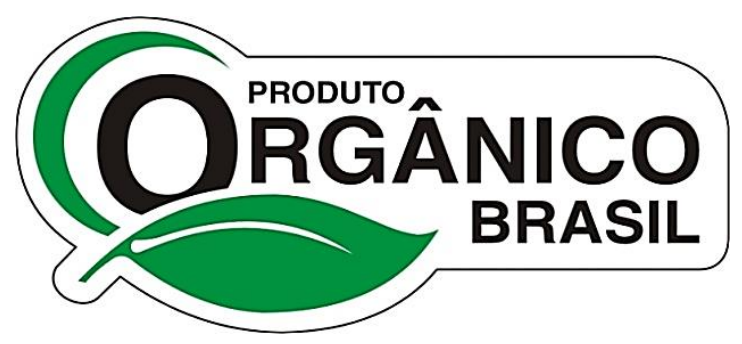

Fonte: Ministério da Agricultura, Pecuária e Abastecimento (2017).

Conforme o Gráfico 1, os estados de Minas Gerais, Espirito Santo, São Paulo, Paraná e Rio Grande do Sul representam cerca de $70 \%$ de tudo aquilo que é produzido de orgânicos no Brasil, mostrando um predomínio das regiões Sul e Sudeste neste tipo de cultivo, no ano de 2017.

Gráfico 1 - Estados Brasileiros com maior participação na produção de alimentos orgânicos.

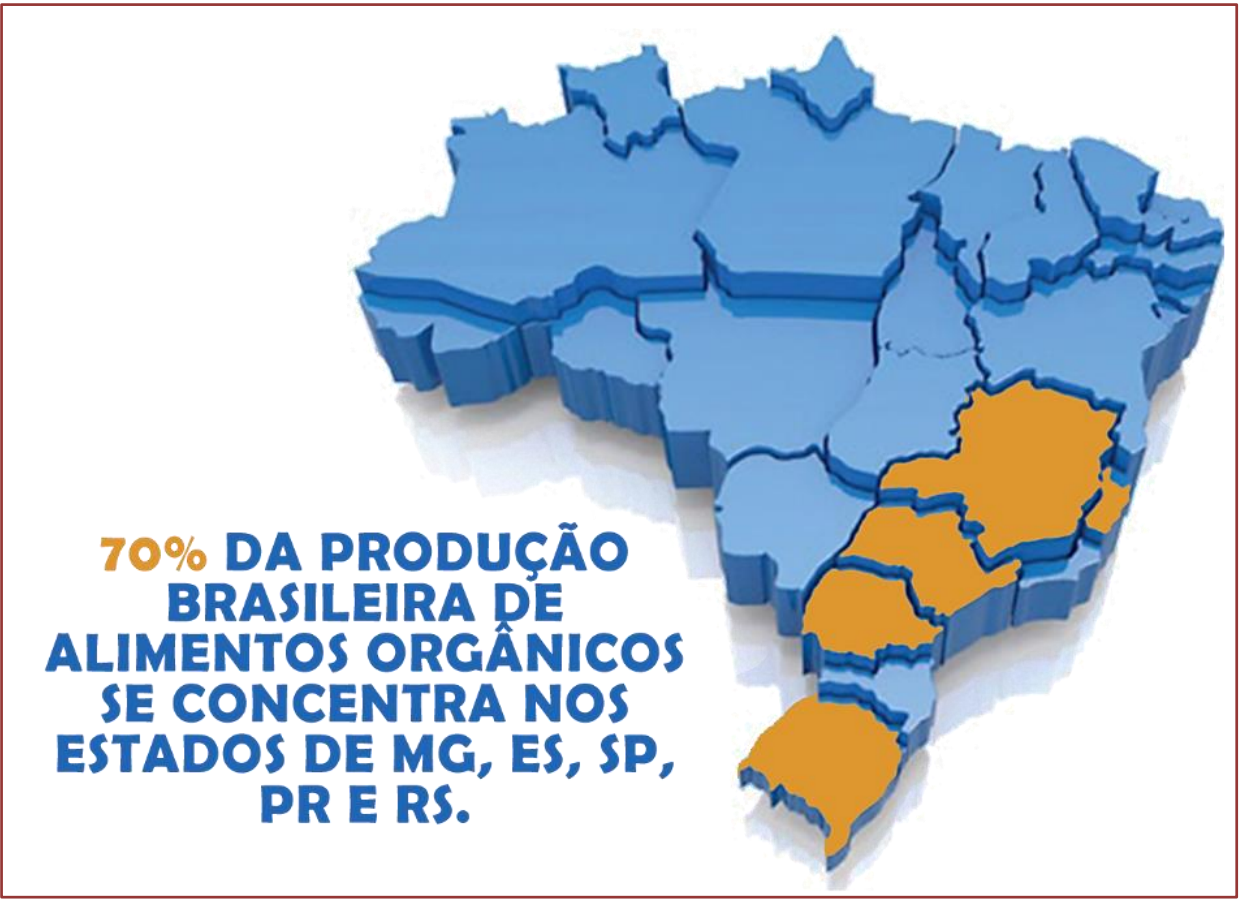

Fonte: MAPA (2017); Elaboração própria.

No Gráfico 2 dados que refletem um panorama da produção de orgânicos no Brasil (Organis, 2019). Como mostra, é possível realizar uma comparação, entre os anos de 2017 e 2019, sobre o consumo de produtos orgânicos. 
Gráfico 2 - Produtos orgânicos mais consumidos

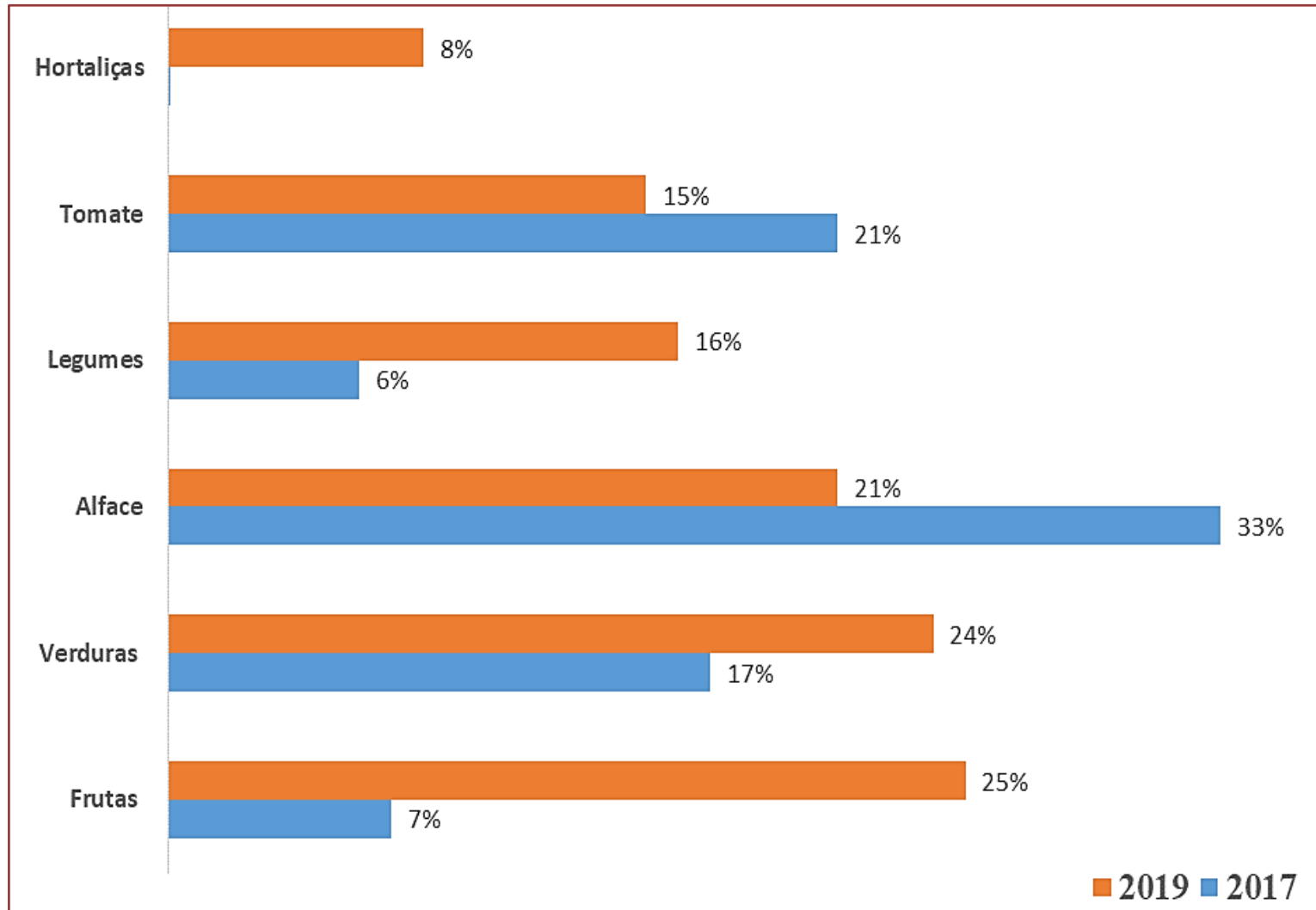

Fonte: Organis (2019). Elaboração própria.

Dentre os produtos mais consumidos estão as frutas, com maior destaque, com 25\% das respostas dos entrevistados, e fruta também obteve um crescimento quando comparado os anos de 2017 e 2019 . Por sua vez o consumo de alface e tomate diminuíram. Não foram disponibilizados dados sobre o consumo de hortaliças em 2017.

Em 2015 foi realizada a 11ํ edição da Semana dos Alimentos Orgânicos, onde dados do MAPA foram divulgados, tais como quais eram os produtos orgânicos mais produzidos e quais demandavam área de plantio. Os mais produzidos foram soja (31\%), hortaliças (27\%) e café (25\%). A soja orgânica vem conquistando o consumidor brasileiro, porém sua maior produção direciona-se a exportação para países europeus, segundo EMBRAPA SOJA (2020); já os que demandam maior tamanho de área para plantio são as frutas (26\%), cana (23\%) e palmito (18\%).

Hoje, grande parte dos produtores orgânicos são familiares e possuem pequena ou média propriedade, sendo sua produção direcionada a culturas que possam trazer um rápido retorno financeiro e que sejam fáceis de manejar, que é o caso das verduras, frutas e hortaliças. A soja, por sua vez, é geralmente produzida por indústrias alimentícias onde que direcionam sua colheita para a fabricação de óleos, farelos e outros, sendo por meio dos produtos transformados que chegam ao consumidor final.

\section{CONCLUSÕES}

Cada região possui sua particularidade em relação a comercialização, produção para exportação ou para abastecer o mercado doméstico e cultura escolhida para o plantio. A região Sul é a que mais se destaca pelo seu número de produtores orgânicos, seguida do Nordeste e Sudeste. Quando o quesito é produção as regiões Sul e Sudeste se destacam.

Dentre as culturas orgânicas mais consumidas destacam-se frutas e verduras. Já as mais produzidas são soja, hortaliças e café e as que demandam maior área são frutas, cana e palmito. Esses dados demonstram 
a diversidade de produção coexistindo, tantos produtos que fazem parte da pauta de exportação brasileira, como para serem consumidos no mercado doméstico.

A certificação do produto, por sua vez, traz aos consumidores a sensação de segurança, além de saber que esse produto está livre de contaminantes, garantindo a qualidade. As três opções de certificação hoje existentes são utilizadas por produtores que podem escolher de acordo com sua condição, de modo que agregue valor ao seu produto e traga retorno. Hoje, a certificação por auditoria, é a opção que os produtores mais utilizam, ressaltando que existem diferenças regionais também quanto à modalidade de certificação.

Por fim, vale destacar que, o mercado de orgânicos é uma área que vem crescendo no cenário nacional, mas que ainda é pouco explorada, como apontada pela sua baixa representatividade no total nacional, possibilitando oportunidade para a capacitação do produtor rural e para a ampliação da produção de orgânicos no Brasil.

\section{REFERÊNCIAS}

[1] AGRAWAL, Akash Deepak. GREEN MARKETING: SUSTAINABLE MARKETING STRATEGY. Indira Management Review, p. 17, 2013.

[2] BlaCkWELL, R. D.; MiNiARD, P. W.; ENGEL, J. F. Comportamento do consumidor. São Paulo: Pioneira Thomson Learning, 2005

[3] BORGUINI, R. G.; TORRES, E. A. F. S. Alimentos orgânicos: qualidade nutritiva e segurança do alimento. Segurança Alimentar e Nutricional, v. 13, n. 2, p. 64-75, 2006.

[4] BRASIL. Lei n.o 10831, de 23 de dezembro de 2003. Dispõe sobre a agricultura orgânica e dá outras providências. Diário Oficial da República Federativa do Brasil.Brasília, 23 dez. 2003. Disponível em: <http://acd.ufrj.br/consumo/legislacao/n_l10831_03.html>. Acesso em: 12 mar. 20.

[5] BRASIL. MINISTÉRIO DA AGRICULTURA, PECUÁRIA E ABASTECIMENTO. Decreto № 6.323, DE 27 DE DEZEMBRO DE 2007. Publicado no Diário Oficial da União, Brasília, 28 de dezembro de 2007. Seção 1 , Páginas 2 a 8.

[6] BRASIL. Legislação para os sistemas orgânicos de produção animal e vegetal. Ministério da Agricultura, Pecuária e Abastecimento. Secretaria de Desenvolvimento Agropecuário e Cooperativismo. Brasília: Mapa/ACS, 2009.

[7] CAMARGO, C. P.; PESSOA, M. C. P. Y.; SILVA, A. S. Qualidade e Certificação de Produtos Agropecuários. Embrapa Informação Tecnológica. Brasília, DF. 2002 Disponível em: http://www.embrapa.br/publicacoes/tecnico/folde TextoDiscussao/arquivos-pdf/texto14.pdf. Acesso em: $11 \mathrm{mar}$. 20.

[8] CRONIN JR, J. Joseph et al. Green marketing strategies: an examination of stakeholders and the opportunities they present.Journal of the Academy of Marketing Science, v. 39, n. 1, p. 158-174, 2011.

[9] ETZEL, M. J., WALKER, B. J. e STANTON, W. Marketing. 11ํo ed. São Paulo: Makron Books, 2001.

[10] GIL, A. C. Métodos e técnicas de pesquisa social. 6. ed. Editora Atlas SA, 2008

[11] GINSBERG, Jill Meredith; BLOOM, Paul N. Choosing the right green marketing strategy.MIT Sloan Management Review, v. 46, n. 1, p. 79-84, 2004.

[12] MAZZOLENI, E. M.; NOGUEIRA, J. M. Agricultura orgânica: características básicas do seu produtor. Rev. Econ. Sociol. Rural, Brasília, v. 44, n. 2, p. 263-293, June 2006.

[13] NAVA, E. J. R. Estratégias de marketing junto ao mercado de consumo para aquisição de alimentos orgânicos: uma abordagem do mix de marketing. Florianópolis: UFSC, 2004. 164p(Dissertação de mestrado).

[14] O’DONOVAN, P., MCCARTHY, M. Irish consumer preference for organic meat. British Food Journal. Bradford: 2002. Vol. 104, pg 353.

[15] OLIVEIRA, A.S.; ALMEIDA JÚNIOR, J.F. Proposta de um produto alimentício orgânico e avaliação comparativa de sua aceitação e preferência sensorial. In: Encontro Latino-Americano de Iniciação Científica, 12., 2008, São José dos Campos

[16] OTTMAN, Jacquelyn. Green Marketing| Sustainability Marketing, The New Rules of Green Marketing Book| J. Ottman Consulting. 2013

[17] PEATTIE, Ken; CRANE, Andrew. Green marketing: legend, myth, farce or prophesy? Qualitative Market Research: An International Journal, v. 8, n. 4, p. 357-370, 2005.

[18] PENTEADO, S.R. Manual Prático de Agricultura Orgânica: Fundamentos e Técnicas. Edição do autor. Campinas, SP, 2009 
[19] STRINGHETA, P. C.; MUNIZ, J. R Alimentos Orgânicos: Produção, Tecnologia e Certificação. Viçosa: UFV, 2003

[20] VILELA, N.J. et al. Perfil dos consumidores de produtos orgânicos no Distrito Federal. Disponível em: <https://www.embrapa.br/hortalicas/busca-de-publicacoes/-/publicacao/779839/perfil-dos-consumidores-deprodutos-organicos-no-distrito-federal>. Acesso em: 11 mar. 20. 


\section{Capítulo 14}

\section{Sustentabilidade socioambiental e impactos na geração elétrica nos pequenos potenciais hídricos do rio Muatala, Nampula - Moçambique}

Alcido Alberto João

António Gonçalves Fortes

Momade Jaime Chau

Claudino Pita Richad

Paulo Baptista Alface

Ernesto Taperero Fernando

Resumo: A geração de energia elétrica, em sistema off grid, por meio de turbinas hidráulicas constitui uma alternativa para suprir a demanda por eletricidade nas zonas rurais e suburbanas não abrangidas pela energia da rede nacional, tanto pela sua capacidade de reduzir a pobreza energética, como para minimizar parte dos problemas socioambientais que o mundo enfrenta. Neste contexto, realizou-se um estudo experimental com objetivo de avaliar o funcionamento de um sistema hidrelétrico com turbina Kaplan e analisar a sustentabilidade socioambiental e impactos associados à implantação do sistema para geração de eletricidade nos pequenos potenciais hídricos da cidade de Nampula, Moçambique. A coleta de dados foi realizada no segundo quadrimestre de 2020. Operando a vazão de $0,01 \mathrm{~m}^{3} / \mathrm{s}$ e $0,75 \mathrm{~m}$ de altura de queda, no sistema, padrão e com engrenagens, gerou-se, respectivamente, uma tensão média de $24,5 \mathrm{~V}$ e $52 \mathrm{~V}$, e a corrente média de $31 \mathrm{~mA}$ e $44 \mathrm{~mA}$, capaz de atender parte das necessidades energéticas domésticas da comunidade local. Em termos de impactos, não houve alterações paisagísticas e dos parâmetros físico-químicos da água. Porém, o sistema teve ineficiências devido às perdas por atrito no gerador e perdas de transmissão na engrenagem. Conclui-se que sistema hidrelétrico com turbina Keplan, construído a partir de materiais alternativos apresenta sustentabilidade socioambiental e econômica, para além de gerar uma potência útil nos rios de baixo declive.

Palavras-chave: sistema hidrelétrico, turbina Kaplan, sustentabilidade, impactos. 


\section{INTRODUÇÃO}

O setor energético é muito importante para o desenvolvimento econômico e social de um país, servindo de apoio na elaboração de políticas públicas e diretrizes, indicativas ou determinativas, para os agentes públicos e privados de oferta e consumo de energia e de regulação seja no gerenciamento de indicadores de eficiência, de qualidade e do meio ambiente (VILA, 2014).

Deste modo, a contribuição do setor energético no contexto da globalização impõe a adoção de medidas que conduzam à estabilidade da procura e oferta dos bens e serviços energéticos para os diferentes estratos da sociedade. Este é o ponto de partida da Política de Desenvolvimento de Energias Novas e Renováveis, na qual se considera que as energias renováveis assumem um papel de destaque no mercado mundial das energias e por darem resposta a diversas imposições globais, como a segurança energética, mudanças climáticas, melhorias no acesso às energias modernas no meio rural e suburbano (MOÇAMBIQUE, 2009a).

Diversos autores pesquisaram sobre o desenvolvimento sustentável, preservação do meio ambiente, geração de emprego e renda e o crescimento econômico. Todas essas questões divergem na geração e utilização das energias renováveis. Porém, os desafios socioambientais e econômicos levam a sociedade a desenvolver técnicas e tecnologias de geração de energia elétrica, a partir de fontes renováveis de energias, que não comprometem o meio ambiente, sendo estas, disponíveis localmente, de baixo custo, eficientes e eficazes.

Em 2013, o Fundo de Energia (FUNAE) de Moçambique realizou estudos para apurar o potencial hídrico do país e foram identificados um total de 1.446 novos possíveis projetos hidrelétricos, com potencial total de 18,6 Gigawatt $(G W)$, sendo Tete, Manica e Nampula as províncias que apresentam maiores potenciais. Destes projetos, apenas 351 locais foram priorizados economicamente, com potencial estimado de 5,6 GW (GUEIFÃO et al., 2013).

Segundo Nhamire e Mosca (2014, p. 9), Moçambique é o segundo maior produtor da eletricidade da região austral de África, com geração média de 2,279 GW. Apesar disso, o País é o quarto da região, com menos acesso à eletricidade pelos cidadãos. Apenas $22 \%$ da população moçambicana usa energia elétrica da rede nacional (ERN). Estes dados mostram a fraca mobilização de recursos e investimentos para produção de energia e a fraca disseminação das tecnologias acessíveis e sustentáveis aos mais necessitados.

Fortes et al. (2020) consideram que as populações que vivem nas comunidades ou áreas isoladas, distantes e de difícil acesso, ficam isentas da ERN, originando-se os problemas de integração da educação, saúde, saneamento, abastecimento de água, melhoria nos processos produtivos de subsistência, estabilidade e insegurança, universalização da informação e a qualidade de vida, no sentido geral.

É neste âmbito que surge a presente pesquisa, para responder as questões relacionadas com práticas sustentáveis e a demanda da eletricidade nas regiões não abrangidas pela ERN, com objetivo de avaliar o funcionamento de um sistema hidrelétrico com turbina Kaplan, analisar a sustentabilidade socioambiental e possíveis impactos associados à implantação do sistema para geração de eletricidade nos pequenos potenciais hídricos no rio Muatala, na cidade de Nampula.

Analisou-se a relevância da utilização deste sistema nos seguintes domínios: (i) segurança - uso de materiais atóxicos; (ii) economia - utilização de materiais alternativos, de fácil acesso, recicláveis e de baixo custo, para geração de eletricidade; (iii) reprodução - fácil manuseio do protótipo em diversos ambientes; (iv) didática - os resultados da presente pesquisa podem ser utilizados na abordagem de conteúdos de eletricidade e energias renováveis no ensino secundário, técnico profissional e superior; (v) tecnológica e ambiental - desenvolvimento de tecnologias locais de ER para geração de eletricidade com baixíssimos impactos ambientais.

\section{REVISÃO DE LITERATURA}

\subsection{CARACTERIZAÇÃO DO SETOR ENERGÉTICO DA CIDADE DE NAMPULA}

A cidade de Nampula é a cidade capital da província de mesmo nome (Fig. 1), localizada na região norte do País. A sua população é estimada em 743.125 habitantes (INE, 2019). O clima predominante é o tropical úmido com duas estações: uma chuvosa e quente, entre os meses de novembro e abril, caracterizado por aguaceiros e trovoadas frequentes. A outra, seca e fria, entre maio e outubro. 0 valor máximo e mínimo absoluto da temperatura do ar é de $33,9{ }^{\circ} \mathrm{C}$ e $19{ }^{\circ} \mathrm{C}$, respectivamente. Quanto à precipitação, a média anual é de 1.045 mm (MAE, 2014). 
A Eletricidade de Moçambique (EDM) é responsável pela eletrificação (geração, transmissão e distribuição) em Moçambique. E o FUNAE está voltado para a eletrificação rural, fora da rede nacional, usando sistemas geradores a diesel e solares.

A maior parte da eletricidade usada na cidade de Nampula é da ERN gerada pelas centrais hidrelétricas existentes no país, seguindo da energia fotovoltaica. Para uso doméstico, ainda se utiliza a biomassa lenhosa, gás de cozinha, petróleo, velas, pilhas alcalinas e baterias.

Figura 1: Localização geográfica da cidade de Nampula.

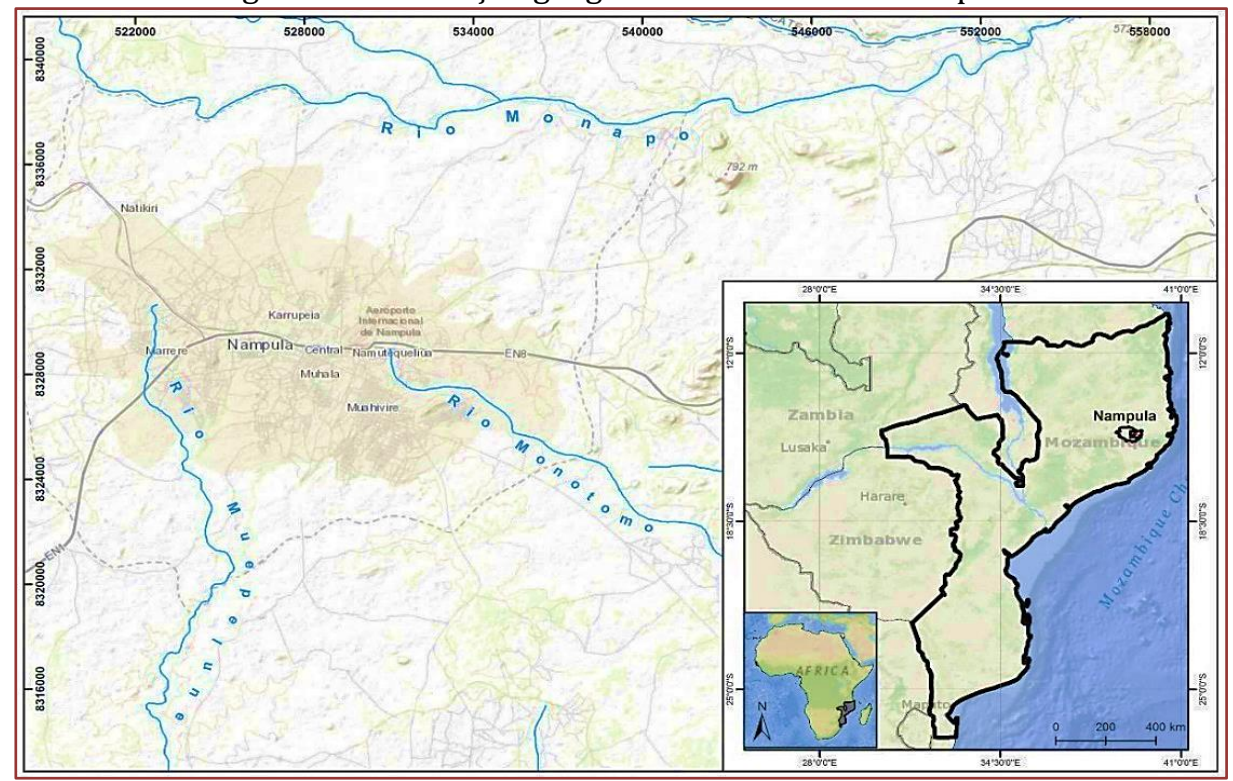

Fonte: Dados dos Autores (2021).

\subsection{ENERGIA HIDRELÉTRICA E CENTRAIS HIDRELÉTRICAS}

A energia hidrelétrica é aquela que provém da condensação, precipitação e evaporação das águas, fatores estes causados pela irradiação solar e atração gravitacional. As usinas hidrelétricas têm a capacidade de transformar a energia cinética e potencial gravitacional das massas de águas dos rios em energia mecânica e elétrica. Ela vem sendo utilizada a milhares de anos para o bombeamento de água, moagem de grãos, corte de madeiras e pedras para a construção e outras aplicações. A partir do século XVIII passou a ser utilizada para mover máquinas têxteis, e nesse período, foram desenvolvidos os princípios para geração hidrelétrica (GIELENA et al., 2019).

Uma das formas de aproveitamento da massa de água para a geração de eletricidade é através das turbinas hidráulicas, que proporcionaram uma grande revolução no setor industrial, contribuindo no desenvolvimento e aperfeiçoamento de diversos tipos de turbinas, porém, requerem um investimento elevado para a sua aquisição e operacionalização.

O potencial hidráulico mede a capacidade de um rio de gerar energia elétrica (GIELENA et al., 2019). 0 potencial depende da vazão hidráulica e do desnível existente ao longo do curso do rio. Este desnível pode ser: (i) natural, exemplo da cachoeira; (ii) através de uma barragem (Fig. 2A e 2B), (iii) ou através do desvio do leito natural do rio. 
Figura 2: Usina hidrelétrica. A: hidrelétrica de Cahora Bassa em Moçambique; B: Componentes de uma usina hidrelétrica.

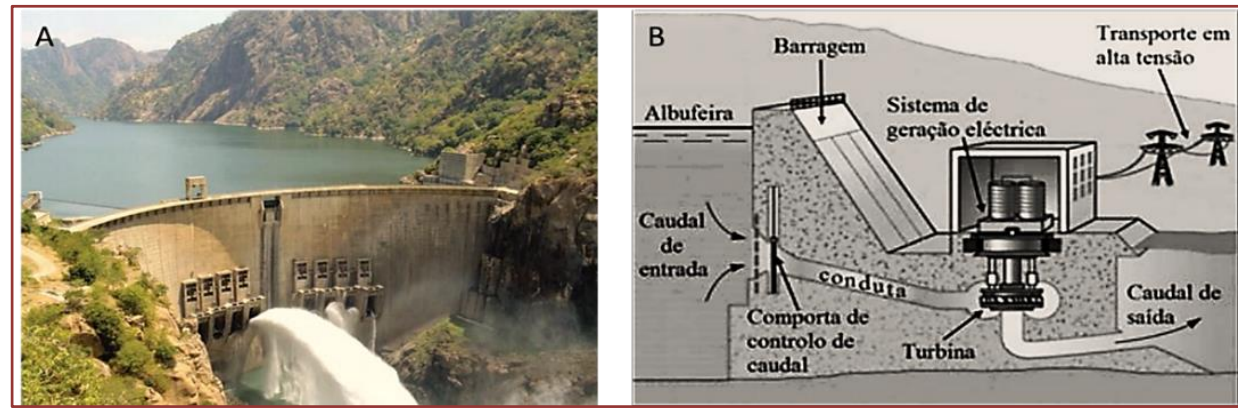

Fonte: Adaptado de (GUEIFÃO et al., 2013).

As turbinas hidráulicas são máquinas primárias que transformam as energias cinética e gravitacional, armazenada na água que circula pelo circuito hidráulico, em energia mecânica, a qual faz acionar um gerador elétrico (GOMES; CAMIOTO, 2016).

As turbinas hidráulicas possuem um princípio de funcionamento comum. A água entra na turbina vinda de um reservatório e escapa para um canal de nível mais baixo (Fig. 2B). A água que entra é conduzida por um ducto fechado até um conjunto de palhetas ou injetores que transferem a energia mecânica (energia de pressão e cinética) do fluxo de água em potência de eixo. A pressão e a velocidade da água na saída são menores que na entrada (Fig. 2A). A água que sai da turbina é conduzida por um ducto até um canal inferior (JÚNIOR, 2013, p. 9).

Dependendo da variação da pressão e da direção do fluxo, as turbinas hidráulicas podem ser classificadas conforme apresentado na tabela 1.

Tabela 1: Classificação das turbinas hidráulicas

\begin{tabular}{|c|c|l|c|}
\hline \multicolumn{1}{|c|}{$\begin{array}{c}\text { Quansificação das turbinas } \\
\text { variação da } \\
\text { pressão estática }\end{array}$} & $\begin{array}{c}\text { Ação ou } \\
\text { impulso }\end{array}$ & $\begin{array}{l}\text { Quando a turbina aproveita a energia cinética de um jato de } \\
\text { água incidindo sobre as pás e a transformação se dá à } \\
\text { pressão constante. }\end{array}$ & Pelton \\
\cline { 2 - 4 } & Reação & $\begin{array}{l}\text { Quando a turbina aproveita a energia cinética de uma } \\
\text { massa de água incidindo sobre as pás e a transformação se } \\
\text { dá à pressão variável. }\end{array}$ & $\begin{array}{c}\text { Hélice, } \\
\text { Kaplan e } \\
\text { Francis }\end{array}$ \\
\hline \multirow{2}{*}{$\begin{array}{c}\text { Quanto a direção } \\
\text { do fluxo }\end{array}$} & Radial & $\begin{array}{l}\text { Quando o fluxo de água que passa pelas pás do rotor se } \\
\text { efetua na direção radial. }\end{array}$ & Francis \\
\cline { 2 - 4 } & Tangencial & $\begin{array}{l}\text { Quando o fluxo de água que passa pelas pás do rotor toma a } \\
\text { direção do eixo da turbina. }\end{array}$ & $\begin{array}{c}\text { Kaplan, } \\
\text { Quando a água incide nas pás na direção tangencial ao } \\
\text { rotor. }\end{array}$ \\
\cline { 2 - 4 } & Diagonal & $\begin{array}{l}\text { Quando o fluxo de água que passa pelas pás do rotor toma a } \\
\text { direção radial e axial do eixo da turbina. }\end{array}$ & Felton \\
\cline { 2 - 4 } & \multicolumn{2}{|c|}{ Fonte: Adaptado de (JÚNIOR, 2013) } \\
\hline
\end{tabular}

Geralmente a potência do eixo pode ser aproveitada para a geração de eletricidade por meio de geradores. Para casos em que a rotação do eixo da turbina é muito baixa, Barreto et al. (2008) recomendam o uso de multiplicadores de velocidade do tipo correia e polia ou caixa de transmissão mecânica. Gomes e Camioto (2016) consideram que o uso desses dispositivos resulta em perdas mecânicas e no aumento no trabalho de manutenção do gerador.

A escolha do tipo de turbina depende da altura de queda e da vazão volumétrica disponível (GOMES; CAMIOTO, 2016). Portanto, neste trabalho vai-se abordar apenas os aspectos conceituais e técnicos das turbinas Kaplan - objeto de estudo.

A turbina Kaplan (Fig. 3) foi criada pelo engenheiro austríaco Viktor Kaplan (1876-1934) que, por meio de estudos teóricos e experimentais, a partir das turbinas de Hélice com a possibilidade de variar o passo das pás (JÚNIOR, 2013). As turbinas Kaplan podem ter eixo vertical ou horizontal e são classificadas como 
turbinas de reação, geralmente adequadas às quedas fracas, caudais elevados e a potência unitária na turbina aumenta quando a configuração é vertical, pois permite diâmetros do rotor muito maiores.

Figura 3: Esquema de uma turbina Kaplan de eixo: A: vertical; B: horizontal.

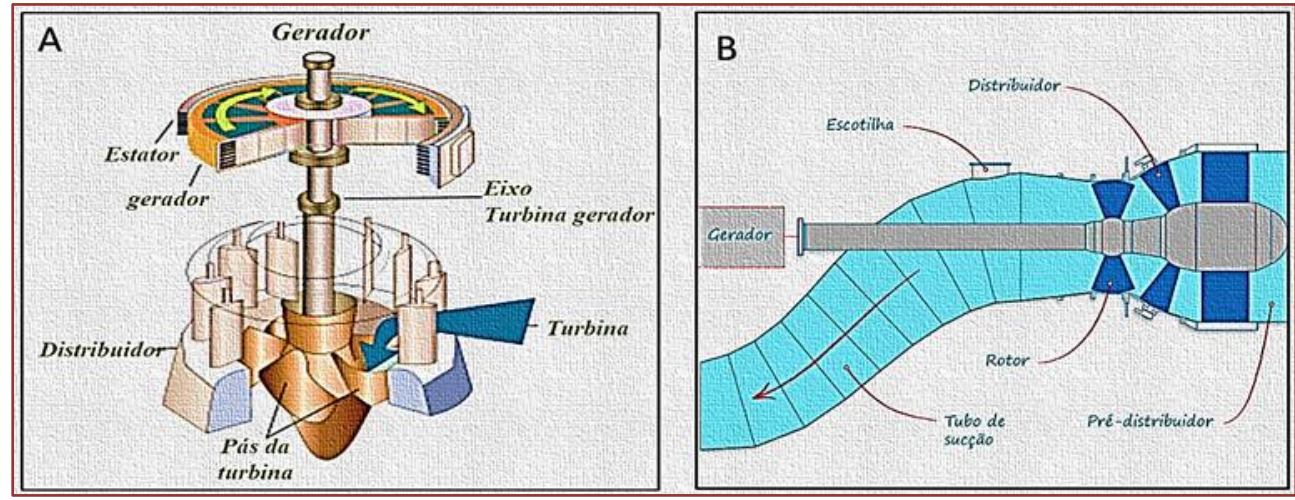

Fonte: (BARRETO et al., 2008, p. 46).

Quanto ao seu funcionamento, a turbina Kaplan é movida pela pressão estática associada a efeitos de reação, ou seja, as pás se movem por causa da diferença de pressão na entrada e saída da turbina. De acordo com Caus e Michels (2017),

A coluna de água exerce uma pressão sobre as pás em forma ou não de hélices, colocadas em um eixo, fazendo as girar com grande velocidade, nesse caso, a água entra na turbina com uma grande pressão e sai com uma pressão muito menor o que faz melhorar o rendimento da turbina (CAUS; MICHELS, 2017, p. 17).

Essa diferença de pressão na entrada e saída da turbina é convertida em energia cinética das pás que faz girar o eixo da turbina. Para o estudo do comportamento das turbinas Kaplan é importante conhecer as grandezas (tabela 2) que influenciam no seu funcionamento, sobretudo, a vazão, a altura de queda, as potências e o rendimento.

Tabela 2: Conceitos e expressão matemática dos parâmetros usados na análise do sistema hidrelétrico

\begin{tabular}{|c|c|c|c|}
\hline Grandeza & Conceito & Fórmula & Expressão \\
\hline Altura de queda (H) & $\begin{array}{l}\text { A altura vertical entre dois níveis de água, entre o } \\
\text { ponto de captação }\left(\mathrm{H}_{\mathrm{d}}\right) \text { e ponto de restituição }\left(\mathrm{H}_{\mathrm{p}}\right) \text {. }\end{array}$ & $H_{d}=H-H_{p}$ & (2) \\
\hline Potência bruta $\left(\mathbf{P}_{\mathbf{b}}\right)$ & $\begin{array}{l}\text { A potência contida no desnível topográfico da } \\
\text { instalação, que depende da vazão (Q) e altura de } \\
\text { queda }(H) \text {. }\end{array}$ & $P_{b}=\rho g Q H$ & (3) \\
\hline Velocidade de rotação $(n)$ & $\begin{array}{l}\text { A velocidade com que o eixo da turbina e/ou gerador } \\
\text { gira. Ela depende do número de dentes }\left(z_{1}\right) \text { e rotação } \\
\left(n_{1}\right) \text { da engrenagem e número de dentes }\left(z_{1}\right) \text { da } \\
\text { engrenagem maior. }\end{array}$ & $n_{2}=n_{1} \frac{Z_{2}}{Z_{1}}$ & (4) \\
\hline Potência hidráulica $\left(P_{d}\right)$ & $\begin{array}{l}\text { A potência disponível para ser aproveitada pela } \\
\text { turbina. Ela é diretamente proporcional a vazão }(Q) \text { e } \\
\text { altura disponível }\left(H_{d}\right) \text {. }\end{array}$ & $P_{d}=\rho g Q H_{d}$ & (5) \\
\hline $\begin{array}{l}\text { Potência extraída pelo } \\
\text { gerador }\left(P_{G}\right)\end{array}$ & $\begin{array}{l}\text { A energia elétrica nos terminais do gerador varia em } \\
\text { função da tensão gerada (U) e da intensidade da } \\
\text { corrente (I). }\end{array}$ & $P_{G}=U \cdot I$ & $(6)$ \\
\hline Rendimento da turbina $\left(\eta_{t}\right)$ & $\begin{array}{l}\text { A energia total }\left(P_{m}\right) \text { que a turbina consegue extrair da } \\
\text { fonte hidráulica disponível }\left(P_{d}\right) \text {. }\end{array}$ & $\eta_{t}=\frac{P_{m}}{P_{d}}$ & $(8)$ \\
\hline Rendimento do sistema $\left(\eta_{T}\right)$ & $\begin{array}{l}\text { A energia total }\left(P_{G}\right) \text { que o sistema consegue extrair da } \\
\text { fonte hidráulica disponível }\left(P_{d}\right) \text {. }\end{array}$ & $\eta_{T}=\frac{P_{G}}{P_{d}}$ & (9) \\
\hline
\end{tabular}




\subsection{IMPACTOS NA GERAÇÃO HIDRELÉTRICA EM PEQUENA ESCALA}

Segundo Gueifão et al. (2013), considera-se pequenas centrais hidrelétricas (PCHs), as centrais cuja potência instalada não ultrapassa $10 \mathrm{MW}$. As PCHs são infraestruturas importantes para a geração de energia descentralizada, por serem de menor porte, estes apresentarem maior simplicidade na concepção e na operação, um custo relativamente reduzido em relação às grandes usinas hidrelétricas, pelo seu menor impacto sobre o ambiente e rapidez no processo de instalação. Para as PCHs, geralmente não utilizam reservatórios para represa de grandes volumes de água e normalmente operam a fio de água, permitindo a passagem contínua do rio com uma capacidade nominal estável.

As PCHs apresentam três características principais: (i) rápida entrada no sistema de potência e flexibilidade para mudar rapidamente a quantidade de energia proporcionada ao sistema; (ii) baixos custos de operação, manutenção e de geração de energia; e (iii) propriedades mais suaves de inserção ambiental.

As PCHs mostram-se uma alternativa interessante, visto que representam uma forma de geração de energia limpa e renovável, de baixo custo em comparação com outras formas, e com condições de atendimento a locais isolados. Além disso, Geller (2016) afirma que tais desenvolvimentos energéticos não produzem nenhuma emissão atmosférica durante a geração de eletricidade, sendo o principal benefício ambiental das PCHs o deslocamento ou a vacância das emissões da geração de eletricidade convencional, repercutindo em um impacto positivo de proporção global.

Mesmo sendo uma fonte de energia limpa, alguns impactos ambientais podem surgir dos desenvolvimentos de PCHs e tendem a afetar as comunidades e ecossistemas. Segundo a lei do ambiente moçambicana, considera-se "impacto ambiental a qualquer mudança do ambiente, para melhor ou para pior, especialmente com efeitos no ar, na terra, na água e na saúde das pessoas, resultantes da atividade humana" (MOÇAMBIQUE, 1997a, art. 1, § 16).

Segundo Barreto et al. (2008) os impactos são classificados em negativos ou positivos e podem afetar três dimensões: meio físico, meio biótico e o meio antrópico. Compreende-se como meio físico afetado o curso de água, o solo e a atmosfera, como meio biótico a fauna e a flora e como meio antrópico as comunidades locais.

Assim sendo, são considerados impactos ambientais na geração de energia hídrica, o alagamento de importantes áreas florestais, destruição de extensas áreas de vegetação natural, matas ciliares, o desmoronamento das margens, o assoreamento do leito dos rios, prejuízos à fauna e à flora locais, alterações no regime hidráulico dos rios, possibilidades da transmissão de doenças e a emissão dos gases de efeito estufa (GEE) na atmosfera, na sua maioria são ocasionados pelo represamento da água (GELLER, 2016; MOÇAMBIQUE, 1997).

As usinas com reservatório possuem uma contribuição significativa para as emissões de GEE, principalmente nos 10 primeiros anos da operação da usina. Usinas localizadas em clima tropical devem ser avaliadas de forma particular, e poucos estudos existem considerando este contexto. 0 bioma que compõe a área inundada, também contribui para maior ou menor produção dos gases metano e carbônico. Em relação ao tamanho e profundidade, as emissões são maiores em reservatórios extensos e rasos. Em relação ao tempo de operação, há um consenso das pesquisas que afirmam que as emissões diminuem conforme o tempo (GELLER, 2016, p. 36).

Para além dos impactos ambientais, há também os impactos sociais que não devem ser deixados de lado, como é o caso de alagamento de propriedades, casas e áreas produtivas (GELLER, 2016). Ou seja, a inundação de áreas para a construção de barragens gera problemas de realocação das populações ribeirinhas, comunidades indígenas e pequenos agricultores. Portanto, cada rio apresenta características únicas, por esse motivo, efeitos variam de acordo com cada rio e cada vez mais é importante que se faça a avaliação integrada do rio e da bacia, para que se tenha a noção dos efeitos cumulativos levando em conta a conservação ambiental e a manutenção da qualidade de vida da população. 


\subsection{SUSTENTABILIDADE E ENERGIAS RENOVÁVEIS}

A discussão mais concreta e prática sobre o "desenvolvimento sustentável", emerge na Conferência sobre o Meio Ambiente de 1972, realizada em Estocolmo, na Suécia pela Organização das Nações Unidas (ONU). O debate central da conferência foi a questão do desenvolvimento econômico a partir da observância dos conceitos de sustentabilidade, como "aquele que atende às necessidades do presente sem comprometer a possibilidade de as gerações futuras atenderem às suas próprias necessidades". Em seguida, na Conferência Mundial da ONU sobre Meio Ambiente e Desenvolvimento realizada no Rio de Janeiro em 1992, houve a criação da Agenda 21, que estabelecia a obrigatoriedade da regulação ambiental "proteção ambiental, desenvolvimento econômico e justiça social" através da cooperação entre países e da transmissão de informação às populações. Desde então, vêm se propondo diversos indicadores e índices para avaliar o progresso dos países em direção ao desenvolvimento sustentável, estabelecendo relações de causalidade e medidas necessárias (DUTRA; MARQUES, 2014; ONU, 2015).

Uma sociedade moderna só opera com o uso de uma ou mais formas de energia. A racionalização do seu uso possibilita melhor qualidade de vida, gerando consequentemente, crescimento econômico, emprego, autoemprego e competitividade. Uma política de ação referente à eficiência energética tem como meta o emprego de técnicas e práticas capazes de promover o uso inteligente da energia, reduzindo custos e produzindo ganhos na perspectiva do desenvolvimento sustentável (EDENR MOÇAMBIQUE, 2011, p: 27).

Dutra e Marques (2014, p. 4) consideram que "o desafio do desenvolvimento sustentável não tem como ser enfrentado a partir da perspectiva teórica que desconsidera as dimensões culturais e éticas no processo de tomada de decisão". Heinberg (2007) identificou os axiomas (Tabela 3) que facultam a compreensão do conceito.

Tabela 3: Os cinco axiomas da sustentabilidade

\begin{tabular}{|c|c|}
\hline Axioma & Argumentos \\
\hline 1 & $\begin{array}{l}\text { Axioma de Tainter: qualquer sociedade que persista no uso insustentável de recurso crítico pode } \\
\text { colapsar. Excepção: uma sociedade pode evitar o colapso se encontrar recursos de substituição. } \\
\text { Limite à excepção: num mundo finito o número de substituições possíveis é finito. }\end{array}$ \\
\hline 2 & $\begin{array}{l}\text { Axioma de Barlett: o crescimento da população e/ou o crescimento nas taxas de consumo de } \\
\text { recursos não podem ser sustentados. }\end{array}$ \\
\hline 3 & $\begin{array}{l}\text { Para ser sustentável, o uso de recursos renováveis deve decorrer a uma taxa menor ou igual à taxa } \\
\text { de reposição natural do recurso. }\end{array}$ \\
\hline 4 & $\begin{array}{l}\text { Para ser sustentável, o uso de recursos não renováveis deve decorrer a uma taxa decrescente, e a } \\
\text { taxa de decréscimo deve ser maior ou igual à taxa de esgotamento dos recursos. A taxa de } \\
\text { esgotamento consiste na quantidade que é extraída e usada durante um intervalo de tempo } \\
\text { especificado expressa em percentagem do total que resta do recurso (para extração). }\end{array}$ \\
\hline 5 & $\begin{array}{l}\text { A sustentabilidade exige que as substâncias introduzidas no ambiente pelas atividades humanas } \\
\text { sejam minimizadas e tornadas inofensivas para as funções da biosfera. Nos casos em que a } \\
\text { poluição e o consumo de recursos não renováveis tenham ocorrido, a taxas crescentes e ponham } \\
\text { em causa a viabilidade dos ecossistemas, a redução nas taxas de extração e consumo desses } \\
\text { recursos pode ter de ocorrer a uma taxa maior do que a taxa de esgotamento. }\end{array}$ \\
\hline
\end{tabular}

Fonte: Adaptado de HEINBERG (2007). 
Na área energética, o conceito de sustentabilidade foca-se na busca de ferramentas e desenvolvimento das "energias sustentáveis", que visam minimizar os impactos ambientais e criação de mecanismos de produção de modelos alternativos baseados na sustentabilidade. O conceito de energias "sustentáveis", "limpas" ou renováveis baseia-se na utilização direta ou indireta de energia solar na geração das fontes de energia hídrica, solar, eólica e biomassa, com exceção da energia das marés, nuclear e geotérmica (DUTRA; MARQUES, 2014).

O termo "energia sustentável" é usado para denotar sistemas, tecnologias e recursos energéticos que sejam capazes de não apenas suprir, no longo prazo, as necessidades humanas - econômicas e de desenvolvimento - mas também o façam de forma compatível com (i) a preservação da integridade subjacente dos sistemas naturais essenciais, evitando, inclusive, mudanças climáticas catastróficas; (2) a extensão de serviços básicos de energia a mais de 2 bilhões de pessoas no mundo todo que atualmente não têm acesso a formas modernas de energia; e (3) a redução de riscos para a segurança e do potencial para conflitos geopolíticos que poderiam advir da disputa crescente por reservas de petróleo e gás natural distribuídas desigualmente. 0 termo sustentável neste contexto abrange uma gama de objetivos programáticos que vai além da mera adequação de suprimentos (BORBA; GASPAR, 2010, p. 58).

O desenvolvimento tecnológico tem permitido que, aos poucos, elas possam ser aproveitadas quer como energia alternativa, quer na produção de calor e de eletricidade, como a energia eólica, solar, da biomassa, e de PCHs, constituindo-se em fonte convencional de geração de eletricidade (BIZAWU; AGUIAR, 2016). Por isso, a tecnologia, o planeamento e a gestão dos sistemas energéticos são ferramentas que permitem o uso eficiente das formas finitas e alternativas de energia pela atividade humana, de uma forma equitativa.

\subsection{POLÍTICAS ENERGÉTICAS NACIONAIS}

A Lei de Eletricidade, Lei no 21/97 de 1 de outubro, estabelece as regras relativas à produção, transporte, distribuição, comercialização, incluindo importação e exportação, de energia elétrica. Esta lei institui a política geral da organização do setor e gestão do fornecimento de energia elétrica no território moçambicano (MOÇAMBIQUE, 1997b).

A Resolução no 5/98 de 3 de março, define as orientações estratégicas para o desenvolvimento do setor energético, segundo as convenções regionais e mundiais (MOÇAMBIQUE, 1998).

O Decreto no 8/2000 de 20 de abril, estabelece as competências e os procedimentos relativos à atribuição de concessões de produção, transporte, distribuição e comercialização de energia elétrica. Este Decreto foi definido com vista a regulamentar a Lei de Eletricidade no 21/97, de 1 de outubro (MOÇAMBIQUE, 2000).

O Decreto no 45/2004 de 29 de setembro, regula o processo de avaliação do impacto ambiental e revoga o Decreto no78/98 de 29 de dezembro (MOÇAMBIQUE, 2004),

O Decreto no 42/2005 de 29 de novembro, regula as normas referentes à planificação, financiamento, construção, posse, manutenção e operação de instalações de produção, transporte, distribuição e comercialização de eletricidade (MOÇAMBIQUE, 2005).

A Resolução 10/2009 aprova a estratégia de energia e revoga a Resolução nº 24/2000, de 3 de outubro (MOÇAMBIQUE, 2009b). Esta estratégia,

Visa preparar o país, para a transição para um futuro energético sustentável, ampliando a matriz de oferta energética, privilegiando as fontes energéticas endógenas e garantindo simultaneamente o crescimento do acesso por maiores camadas populacionais aos benefícios da energia moderna, em particular da eletricidade a qual pode ser produzida com fontes de energia primária diversificada, comprovada relação entre $o$ acesso à eletricidade e $o$ desenvolvimento humano (MOÇAMBIQUE, 2009a, p. 3-4).

O Decreto no 58/2014, regulamento que define o regime tarifário para as energias novas e renováveis (REFIT), define as tarifas a serem praticadas para comercialização de eletricidade gerada pelas seguintes fontes: biomassa, eólica, hídrica e solar, em função da capacidade instalada. "A Eletricidade de Moçambique é autorizada a transferir os custos de ligação à rede de transporte, associada aos projetos devidamente licenciados pela autoridade competente e elegíveis ao programa REFIT" (MOÇAMBIQUE, 2014a, art. 15). 
O Código de ERN, aprovado pelo Diploma Ministerial nº 184/2014 de 12 de novembro, estabelece as condições técnicas de ligação das instalações à ERN e as condições técnicas de planeamento e exploração da mesma, ficando abrangidos pela sua aplicação o gestor da rede nacional de transporte e de energia elétrica, os concessionários de transporte e de distribuição e os utilizadores ligados à ERN (MOÇAMBIQUE, 2014b).

Relativamente ao procedimento a adotar para o licenciamento dos projetos importa observar o Decreto n. ${ }^{\circ}$ 48/2007, de 22 de outubro, alterado pelo Decreto n.. 10/2016, de 25 de abril, que estabelece o regulamento de licenças para instalações elétricas (RLIE), o qual "tem por fim fixar as normas a seguir nas concessões de licenças para o estabelecimento e exploração de instalações destinadas à produção, transporte, transformação, distribuição e utilização de energia elétrica para qualquer fim ou serviço"(MOÇAMBIQUE, 2016, art. 2).

O RLIE divide em dez categorias as instalações destinadas à produção, transporte, transformação, distribuição e utilização de energia elétrica para qualquer fim ou serviço, de forma a diferenciar o tratamento dado a cada tipo de instalação ao nível de procedimento de licenciamento. No que respeita à geração de energia elétrica com base nas fontes renováveis, as instalações são classificadas na 1aㅡ categoria (art. 3, alínea a). Deste modo, a geração elétrica a partir de fontes renováveis carecem de licença e vistoria prévias para o seu estabelecimento e exploração (art. 4 e 5) e todas as instalações elétricas, ficam sujeitas à fiscalização técnica permanente do Ministério de Recursos Minerais e Energia (MOÇAMBIQUE, 2016).

\section{MATERIAIS E MÉTODOS}

A pesquisa é classificada como aplicada e exploratória, de abordagem quantitativa, baseada na combinação dos métodos bibliográfico, experimental e o trabalho de campo.

Usou-se o método bibliográfico na coleta de dados existentes, sem delimitação espacial e temporal, em diversas obras literárias, manuais, artigos científicos, dissertações e teses. A pesquisa experimental foi usada na construção, testagem e coleta dos dados primários e parâmetros técnicos da pesquisa. E o trabalho de campo utilizou-se para implantar o sistema hidrelétrico construído, no curso do rio Muatala e na coleta/registo dos dados in situ.

Para a coleta de dados fez-se o uso da técnica de observação participante, que através de um protocolo de observação, verificou-se as características do local e análise dos impactos dele.

Para a construção do sistema e sua implantação, usou-se os seguintes materiais (tabela 4):

Tabela 4: Materiais usados para a construção do sistema hidrelétrico

\begin{tabular}{|c|c|}
\hline 1. Construção da Turbina & 2. Construção do gerador \\
\hline \multirow{3}{*}{$\begin{array}{l}\text { Chapa metálica de } 3 \mathrm{~mm} ; \\
1 \text { Rolamentos; } \\
4 \text { parafusos; } \\
\text { - } \\
\text { - } 1 \text { Eixo de } 25 \mathrm{~cm} \text { e } 5 \text { porcas; } \\
\text { - } \quad \text { Uma caixa espiral de } 25 \mathrm{~cm} \text { de altura } 45 \mathrm{~cm} \text { de } \\
\text { - } \quad 2 \text { anilhas e } 10 \mathrm{~cm} \text { de tubo } 1 / 2 .\end{array}$} & $\begin{array}{l}\text { Uma base de madeira de forma circular; } \\
\text { Bobinas e magneto extraído da motorizada; } \\
1 \text { rolamento; } \\
1 \text { eixo e } 6 \text { porcas; } \\
2 \text { parafusos com porca. }\end{array}$ \\
\hline & \multirow{5}{*}{$\begin{array}{l}\text { 5. Coleta de dados } \\
1 \text { voltímetro; } \\
\text { 0 sistema construído; } \\
\text { Fita métrica; } \\
1 \text { balde de } 20 \text { litros; } \\
1 \text { cronómetro; } \\
\text { Um celular e seu carregador; } \\
\text { Duas lâmpadas LED, } 7 \text { w e } 20 \mathrm{~W} ; \\
\text { Uma bactéria chumbo/ácido de } 3 \mathrm{~W} \text { e } \\
\text { - }\end{array}$} \\
\hline & \\
\hline 3. Construção de multiplicador de velo & \\
\hline $\begin{array}{l}2 \text { cubos de bicicleta; } \\
\text { Madeira } 50 \times 30 \mathrm{~cm} ; \\
\text { - } \quad 4 \text { parafusos; } \\
1 \text { eixo de } 25 \mathrm{~cm} \text { e } 5 \text { porcas. }\end{array}$ & \\
\hline 4. Represamento e montage & \\
\hline $\begin{array}{l}\text { Sacos de polietileno de } 25 \mathrm{~kg} \text {; } \\
1 \text { base de ferro. }\end{array}$ & \\
\hline
\end{tabular}

Fonte: Dados dos Autores (2021) 
Os procedimentos experimentais foram divididos em seguintes fases:

Para a Construção da turbina, (i) fez-se os moldes de chapa de zinco e cortou-se as pás (Fig. 4A); (ii) soldou-se as chapas na lateral do tubo de $5 \mathrm{~cm}$ e montou-se o eixo; (iii) pintou-se com tinta anticorrosiva para evitar corrosão durante a operação (Fig. 4B); (iv) fixou-se o rolamento e o rotor no interior da caixa (Fig. 4C); (v) com quatro pedaços de varão de $8 \mathrm{~mm}$ com $60 \mathrm{~cm}$ de comprimento e um varão de $6 \mathrm{~mm}$ e $125,6 \mathrm{~cm}$ de comprimento, fez-se uma base (tabela 5).

Para construção do gerador: (i) com a base de madeira de diâmetro $6 \mathrm{~cm}$, fez-se um orifício no centro e fixou-se um rolamento; (ii) centralizou-se as bobinas e furou-se nas laterais do rolamento de modo a transpassar os parafusos (Fig. 4D); (iii) montou-se o estator, fixou-se um eixo no magneto e conectou-se ao estator passando o eixo no centro do rolamento (Fig. 4E).

Para construção do multiplicador de velocidade: (i) fez-se duas circunferências na madeira com raios de 12 e $4 \mathrm{~cm}$; (ii) com a marcação de $1 \mathrm{~cm}$ para dentro, fez-se 16 dentes na engrenagem maior e 8 na menor (Fig. 4F); (iii) fez-se furos de acordo com as dimensões do eixo; (iv) finalizada as engrenagens, montou-se no sistema (tabela 5).

Tabela 5:Dimensões da turbina, tubo PVC e as engrenagens.

\begin{tabular}{|c|c|c|c|c|c|c|c|}
\hline \multirow[b]{2}{*}{ Grandezas } & \multicolumn{2}{|c|}{ Engrenagens } & \multicolumn{4}{|c|}{ Turbina } & \multirow[b]{2}{*}{$\begin{array}{l}\text { Tubo } \\
\text { PVC }\end{array}$} \\
\hline & Maior & Menor & $\begin{array}{c}\text { Seção de } \\
\text { entrada }\end{array}$ & & & $\begin{array}{l}\text { Seção de } \\
\text { saída }\end{array}$ & \\
\hline Diâmetro (cm) & 24 & 8 & 11 & & & 40 & 11 \\
\hline Raio (cm) & 12 & 4 & 5.5 & & & 20 & 5.5 \\
\hline Compr. $(\mathrm{cm})$ & - & - & - & & & - & 700 \\
\hline Área $\left(\mathrm{cm}^{2}\right)$ & 452,16 & 50,25 & 94,99 & 19,63 & 267,94 & 126 & 94,99 \\
\hline
\end{tabular}

Fonte: Dados dos Autores (2021).

Para represamento e montagem do sistema no rio: (i) fez-se a limpeza no local, encheu-se e montou-se os sacos de areia, de modo a barrar a água e canalizar-se diretamente para a turbina; (ii) instalou-se o sistema no rio, após terminar as fases de represamento (Fig. 4G).

Para a coleta de dados: (i) através do ducto que sai da represa encheu-se o balde de $10 l$ e registou-se o tempo que levou a encher o balde; (ii) mediu-se a altura bruta do rio, o diâmetro e o comprimento do ducto; (iii) registou-se a rotação do eixo da turbina, a tensão e a intensidade da corrente; (iv) descreveu-se os impactos durante a instalação, operação e desinstalação do sistema.

Figura 4: Construção e instalação do sistema. A: Molde das pás; B: rotor pintado; C: turbina pronta; D: estator com as bobinas; E: gerador finalizado; F: engrenagem de madeira; G: sistema instalado no rio.

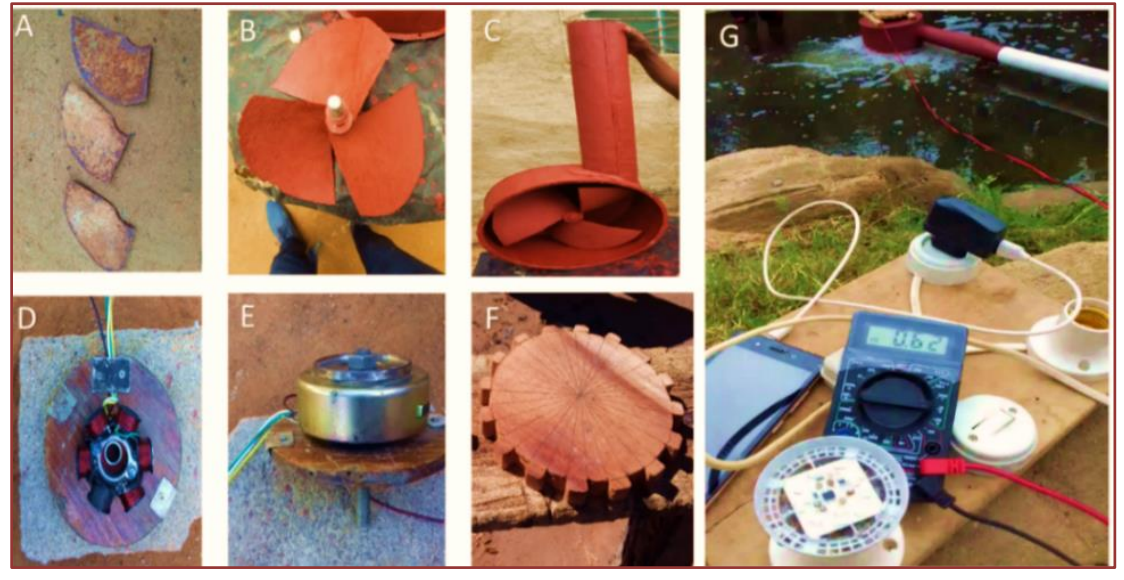

Fonte: Dados dos Autores (2021). 
Para a análise da viabilidade técnica do uso da turbina Keplan construído a partir de materiais alternativos baseou-se nas seguintes etapas: (i) converter as ideias no protótipo funcional; (ii) descrever a funcionalidade e os resultados reais obtidos; (iii) identificar as limitações técnicas do protótipo; (iv) indicar a viabilidade de utilização do protótipo; (v) sugerir adequações, para se equiparar aos respetivos sistemas convencionais ou as necessidades dos consumidores.

O método usado na análise da viabilidade econômica foi o custo nivelado de eletricidade, que consiste na avaliação econômica do valor real do custo de produção de uma unidade geradora de energia. Em seguida fez-se a comparação com o preço das turbinas Keplan convencionais e os sistemas energéticos mais utilizados pela população desprovida da ERN.

\section{RESULTADOS E ANÁLISES}

\subsection{VIABILIDADE TÉCNICA OU DE EFICIÊNCIA}

Inicialmente, instalou-se o sistema no trecho do rio, sem as engrenagens, e permaneceu em funcionamento por cerca de $10 \mathrm{~h} /$ dia, com uma vazão média de $10 \mathrm{l} / \mathrm{s}$ e a altura de queda de 0,75 $\mathrm{m}$. Com 168 rotações por minuto (rpm), o sistema gerou uma tensão de $24,5 \mathrm{~V}$ e corrente de $31 \mathrm{~mA}$ (tabela 6). A seguir, adicionou-se ao sistema as engrenagens, mantendo-se constante a vazão e a altura de queda, os valores de tensão e corrente aumentam respectivamente para $52 \mathrm{~V}$ e $44 \mathrm{~mA}$. Em ambos os casos, testou-se o sistema, carregando uma bateria de chumbo de $3 \mathrm{~W}$.

Tabela 6: Parâmetros técnicos colhidos com o sistema hídrico, com eixo da turbina ligado diretamente com o gerador e com multiplicador de velocidade (MV)

\begin{tabular}{|c|c|c|c|c|c|c|c|c|c|c|c|c|}
\hline \multirow[t]{2}{*}{ MV } & \multirow[t]{2}{*}{ Dia } & \multirow{2}{*}{$\begin{array}{l}\text { Vazão } \\
\text { Média } \\
\left(\mathrm{m}^{3} / \mathrm{s}\right)\end{array}$} & \multirow{2}{*}{$\begin{array}{c}\text { Altura } \\
\text { (m) }\end{array}$} & \multicolumn{3}{|c|}{ Tensão Média (V) } & \multicolumn{3}{|c|}{ Corrente Média (mA) } & \multicolumn{3}{|c|}{$\begin{array}{l}\text { Velocidade de } \\
\text { rotação (rpm) }\end{array}$} \\
\hline & & & & Min & Max & Med & Min & Max & Med & Min & $\operatorname{Max}$ & Med \\
\hline \multirow{3}{*}{$\begin{array}{l}\text { Sem } \\
\text { MV }\end{array}$} & 1 & \multirow{3}{*}{0,01} & \multirow{3}{*}{0,75} & 21,6 & 24,8 & 23,20 & 27,4 & 31,5 & 29,45 & 161 & 165 & 163 \\
\hline & 2 & & & 24,4 & 24,7 & 24,55 & 28 & 29,8 & 28,90 & 166 & 168 & 167 \\
\hline & 3 & & & 23,3 & 24,1 & 23,70 & 27,6 & 31,3 & 29,45 & 162 & 168 & 165 \\
\hline \multirow{3}{*}{$\begin{array}{l}\text { Com } \\
\text { MV }\end{array}$} & 1 & \multirow{3}{*}{0,01} & \multirow{3}{*}{0,75} & 47,3 & 50,4 & 48,85 & 43,3 & 44,6 & 43,95 & 110 & 118 & 114 \\
\hline & 2 & & & 45,1 & 51,3 & 48,20 & 42,4 & 43,16 & 42,75 & 109 & 120 & 114 \\
\hline & 3 & & & 48 & 52,4 & 50,20 & 43,9 & 44,3 & 44,10 & 113 & 121 & 117 \\
\hline
\end{tabular}

Fonte: Dados dos Autores (2021)

A partir dos dados da tabela (6) estimou-se a potência bruta $\left(\mathrm{P}_{\mathrm{b}}\right)$ contida no desnível topográfico do rio (H) que é dado pela expressão 3 , tabela 2 .

$$
P_{b}=\rho \cdot g \cdot Q \cdot H=1000 \cdot 9,8 \cdot 0,01 \cdot 0,75=73,5 \mathrm{~W}
$$

Ou seja, a potência do rio no local testado foi de 73,5 W. Uma parte desta energia foi dissipada na tubulação até chegar na turbina. Enquanto, a potência hidráulica na entrada da turbina $\left(\mathrm{P}_{\mathrm{d}}\right)$ considerando as perdas na tubulação, em função do desnível topográfico $\left(\mathrm{H}_{\mathrm{d}}\right)$ foi de:

$$
P_{d}=\rho \cdot g \cdot Q \cdot H d=1000 \cdot 9,8 \cdot 0,01 \cdot 0,714=70,00 \mathrm{~W}
$$

Para determinar a potência mecânica da turbina $\left(\mathrm{P}_{\mathrm{m}}\right)$, usou-se a área $(\mathrm{A})$ do tubo (tabela 5$)$. A velocidade (v) das pás (tabela 7) foi de $165 \mathrm{rpm}$ (ou 2,8 m/s). A $P_{m}$ foi de:

$$
P_{m}=\rho g h \cdot A \cdot v=1000 \cdot 9,8 \cdot 0,25 \cdot 0,0094985 \cdot 2,7632=64,3 \mathrm{~W}
$$


A $\mathrm{P}_{\mathrm{m}}$ no eixo da turbina antes e depois de inserir as engrenagens foi de 64,3 W e 49,10 W, respectivamente. Isso se deve ao aumento das perdas mecânicas na engrenagem de madeira.

Para determinar a potência extraída pelo gerador, mediu-se a tensão e a corrente média nos terminais do gerador, obtendo-se $49 \mathrm{~V}$ e 43,60 mA respectivamente (tabela 7). Então:

$$
P_{G}=U \cdot I=49 \mathrm{~V} \cdot 43,60 \mathrm{~mA}=2136,4 \mathrm{~mW}=2,14 \mathrm{~W}
$$

Antes e depois de inserir as engrenagens, as potências extraídas pelo gerador foram de 0,7 W e de 2,14 W respectivamente. Esse aumento mostra que a introdução das engrenagens tem impacto na potência extraída pelo gerador de energia. 0 rendimento da turbina $\left(\eta_{t}\right)$ foi de:

$$
\eta_{t}=\frac{P_{m}}{P_{d}}=\frac{64,30 \mathrm{~W}}{70,00 \mathrm{~W}} \cdot 100=92 \%
$$

A turbina construída extraiu cerca de $92 \%$ da energia disponível. Considerando-se as perdas hidráulicas, volumétricas e mecânicas, o rendimento do sistema em geral $\left(\eta_{\mathrm{T}}\right)$ foi:

$$
\eta_{T}=\frac{P_{G}}{P_{d}}=\frac{2136,4 \mathrm{~mW}}{70,00 \mathrm{~W}} \cdot 100=3,05 \%
$$

Isso significa que, o sistema extraiu cerca de 3\% da energia disponível, considerando as perdas na turbina hidráulica (por fricção, hidráulicas, volumétricas e mecânicas), as perdas por transmissão (ao adicionar as engrenagens) e as perdas no gerador (por atrito).

A tabela (7) apresenta o resumo da avaliação do sistema antes e depois de serem adicionadas as engrenagens, mantendo-se constante a vazão média e altura de queda.

Tabela 7: Parâmetros técnicos no sistema hidrelétrico estudado

\begin{tabular}{|l|c|c|c|c|c|}
\multicolumn{1}{c}{ Grandezas } & Rio & Turbina & Gerador & Engrenagem & \multicolumn{1}{c|}{ Sistema } \\
\hline Tensão Média (V) & - & - & 24 & 49 & 49 \\
\hline Corrente Média (mA) & - & - & 29,30 & 43,60 & 43,60 \\
\hline Potência Média (W) & 73.50 & 64,30 & 0,70 & 49,10 & 2,14 \\
\hline Rendimento (\%) & 100 & 92 & 1,1 & 76,4 & 3,0 \\
\hline Frequência linear (Hz) & - & 2,75 & 2,75 & 2,1 & 4,2 \\
\hline Velocidade de rotação média (rpm) & - & 165 & 165 & 126 & 252 \\
\hline
\end{tabular}

Fonte: Dados dos Autores (2021).

No geral, as perdas no sistema hidrelétrico são inevitáveis. Segundo Caus e Michels (2017, p. 3) “em turbinas hidráulicas, o rendimento representa as perdas verificadas nas diferentes condições de operação, considerando que uma parte da potência disponível nos eixos da turbina é dissipada em perdas internas $e$ externas na própria turbina". Assim sendo, a figura 5 apresenta a relação das perdas do sistema construído: 
Figura 5: Perdas no sistema hidrelétrico construído.

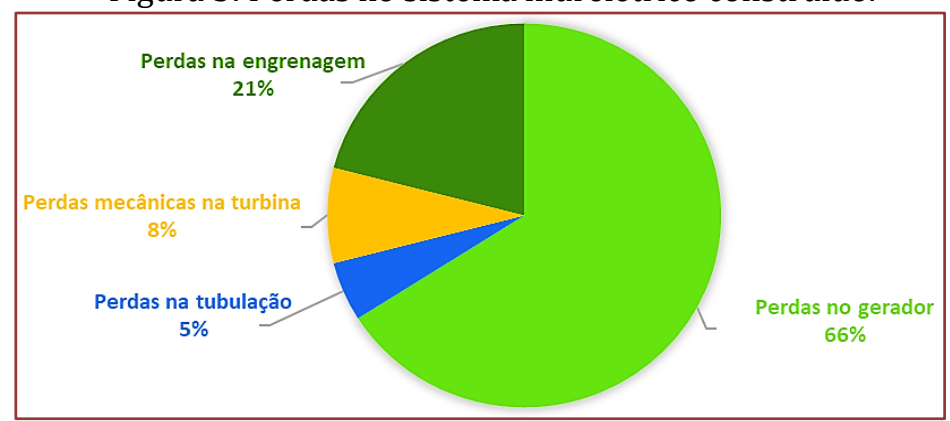

Fonte: Dados dos Autores (2021)

As principais causas da baixa eficiência na turbina construída foram provenientes das perdas hidráulicas ou volumétricas da água dentro da turbina e das perdas mecânicas, causado pelo atrito nos rolamentos que converte parte da energia extraída da água em calor (efeito Joule). Além disso, Yamachita (2013) indica como principais causas da baixa eficiência dos geradores, as perdas por histerese magnética, por corrente de Foucault, por efeito Joule no estator e no rotor, e por atrito nos rolamentos, que convertem parte de energia mecânica em calor.

\subsection{VIABILIDADE ECONÓMICA}

Na tabela 8, estão apresentados os gastos de materiais e serviços, realizados na projeção, construção, instalação e desinstalação do sistema.

Tabela 8: Relação entre materiais e os gastos realizados durante a pesquisa.

\begin{tabular}{|c|c|c|c|c|}
\hline Materiais & Quantidade & $\begin{array}{l}\text { Preço/unidade } \\
\text { (meticais-MTn }{ }^{6} \text { ) }\end{array}$ & $\begin{array}{l}\text { Preço total } \\
\text { (MTn) }\end{array}$ & Observação \\
\hline Estator rotor Magnético & 1 & - & - & Reciclável \\
\hline Chapa 3mm (aço) & 1 & - & - & Reciclável \\
\hline Tubo cilíndrico $5 \mathrm{~mm}$ & 1 & 50,00 & 50,00 & - \\
\hline Chapa 1mm (Zinco) & 1 & - & - & Reciclável \\
\hline Eixo & 2 & 100,00 & 200,00 & - \\
\hline Tubo Pvc $110 \mathrm{~mm}$ & $6 \mathrm{~m}$ & 150,00 & 900,00 & - \\
\hline Madeira 40x30 cm & 1 & - & - & Reciclável \\
\hline Porcas & 11 & 10,00 & 110,00 & - \\
\hline Varrão & 2 & - & - & Reciclável \\
\hline Rolamento & 2 & 50,00 & 100,00 & - \\
\hline Parafuso de chapa & $1 \mathrm{~kg}$ & 100,00 & 100,00 & - \\
\hline Parafuso com porca & 2 & 20,00 & 40,00 & - \\
\hline Pregos 2 polegadas & $1 / 4 \mathrm{~kg}$ & 100,00 & 25,00 & - \\
\hline Fio de ligação $2 \times 2.5 \mathrm{~mm}$ & $5 \mathrm{~m}$ & 10,00 & 50,00 & - \\
\hline Lâmpada Led & 2 & - & - & Reutilizado \\
\hline Interruptor & 1 & - & - & Reutilizado \\
\hline Distribuidor & 1 & - & - & Reutilizado \\
\hline Bocal & 2 & - & - & Reutilizado \\
\hline Tomada & 1 & - & - & Reutilizado \\
\hline Tinta anticorrosivo $1 \mathrm{~L}$ & 1 & 300,00 & 300,00 & - \\
\hline Sacos de polietileno de $25 \mathrm{~kg}$ & 5 & - & - & Recicláveis \\
\hline \multicolumn{3}{|c|}{ Total material } & \multicolumn{2}{|c|}{ 1,875 MTn } \\
\hline Serviços & \multicolumn{2}{|c|}{ Função } & Pagamento & Observação \\
\hline Carpinteiro & \multicolumn{2}{|c|}{ Engrenagens e base do gerador } & 150,00 & - \\
\hline Ratoneiro (bate chapa) & \multicolumn{2}{|c|}{ Tubo espiral } & 300,00 & - \\
\hline Serralheiro & \multicolumn{2}{|c|}{ Cortar e soldar pás e fazer a base } & 300,00 & - \\
\hline Diversos & \multicolumn{2}{|c|}{ Transporte, Material de limpeza } & 310,00 & - \\
\hline \multicolumn{3}{|l|}{ Total Serviços } & \multicolumn{2}{|c|}{$1.060,00$} \\
\hline \multicolumn{3}{|l|}{ Total gasto } & \multicolumn{2}{|c|}{$2.935,00$} \\
\hline
\end{tabular}

61 dólar norte americano (USD) equivale a 73,1 meticais (MTn). Fonte: Banco de Moçambique "http://www.bancomoc.mz/fm_mercadosmmi.aspx?id=10". Acesso no dia 20/03/2021 
Fonte: Dados dos Autores (2021).

Pelas condições dos materiais usados, o sistema construído possui todas as condições técnicas para permanecer em operação num período acima de 10 anos. Foram utilizados ferros, chapas de aço e de zinco revestidas de tinta anticorrosiva, para aumentar o tempo de vida do sistema.

0 total de gastos (tabela 8) mostram que o protótipo é viável economicamente, em comparação com o sistema de turbina Kaplan convencional, que seus preços variam no mercado nacional entre 15.000,0025.000,00 MTn, consoante o fabricante, o modelo, a potência e a eficiência da turbina. Comparativamente as pilhas alcalinas (fonte mais usada pela população rural), o sistema é viável economicamente devido a vida útil das pilhas e a poluição que tem causado ao meio ambiente, sobretudo quando descartadas de forma incorreta, podendo contaminar o solo, as águas superficiais e o lençol freático, visto que elas são altamente tóxicas por conterem altos teores de metais como zinco, chumbo e manganês.

\subsection{IMPACTOS SOCIOAMBIENTAIS}

Os impactos ambientais podem advir de várias formas, desde a construção, a implantação e a desativação da central, sobretudo a emissão de GEE no meio ambiente, causados pela queima de matéria orgânica e inorgânica, eliminação de plantas para dar lugar a central, ruídos e perda da flora e da fauna existentes no rio e na área circunvizinha. Mas segundo Kemerich et al. (2011, p. 149), “... alguns impactos podem ser rapidamente excluídos da preocupação social, como é o caso da geração de ruídos e impacto visual, a partir da criação de uma camada vegetal que possa cercar o empreendimento".

Nesse âmbito, durante a implantação do sistema no local, não houve mudanças em termos paisagísticos e florísticos, devido à dimensão reduzida deste (Fig. 6A), a hidrologia do rio e as condições geológicas locais, caracterizado por maciço gnáissico descontínuo, estável e não coberto. Por esses motivos, não houve necessidade de ocupar grandes áreas para a sua instalação e reduzindo sincronicamente os impactos socioambientais diretos, tais como, o alagamento de propriedades, casas e áreas produtivas.

Por não afetar de forma significativa os parâmetros físico-químicos da água, como o cheiro, turbidez, pH, condutividade, temperatura e total de sólidos dissolvidos, a água após o contato com o sistema pode ser reutilizada, para as mesmas aplicações de tempos antes do contato com o sistema: confecção de blocos e tijolos, irrigação, lavagem de roupa, tomar banho, alimentação de animais domésticos e outras eventuais atividades domésticas.

Quanto a morte dos seres vivos existentes no rio é inevitável. Notou-se que existem habitat no rio, que de certa forma pode haver uma atração pela pressão da água na tubulação, acabando por serem esmagados pelas pás da turbina, constituindo o impacto ambiental mais significativo. Assim sendo, para sistemas permanentes ou de grande porte, a solução é colocar uma rede de cobertura para diminuição deste tipo de impacto.

Segundo as condições do sistema em termos de dimensões e a forma do rio não houve nenhum impacto negativo para a sociedade. Nenhuma machamba está próxima do local de instalação do sistema, por isso não houve necessidade de reassentamento da população para dar espaço a instalação da PCH (Fig. 6A e 6B).

Figura 6: características do local. A: o sistema instalado; B: após a desinstalação do sistema.

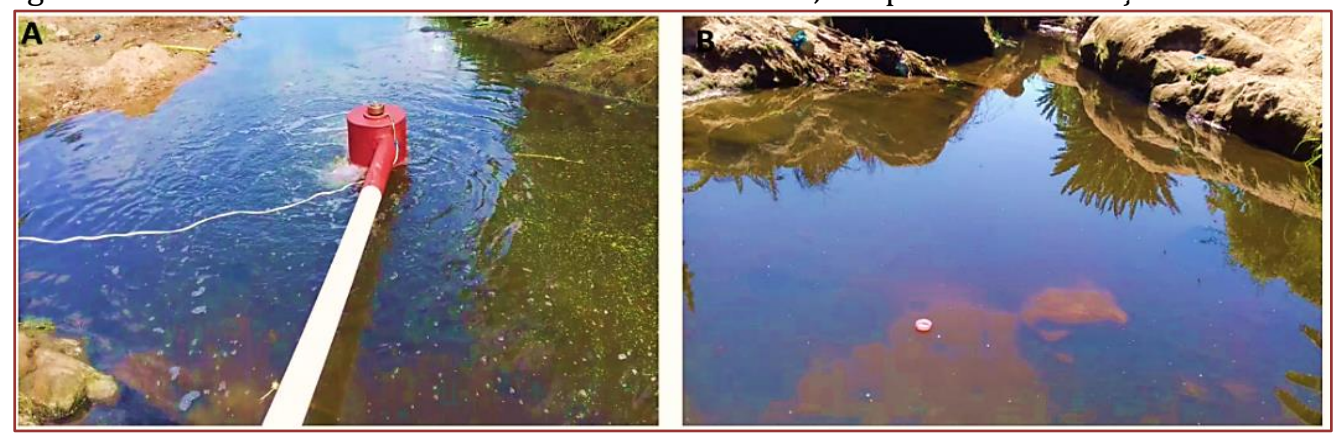

Fonte: Dados dos Autores (2021). 


\subsection{ANÁLISE DOS RESULTADOS}

O setor energético tem um papel crucial para o desenvolvimento socioeconômico de um País, constituindo um dos indicadores de qualidade de vida. A falta de acesso à eletricidade, sobretudo, nas áreas rurais e suburbanas inviabiliza o acesso a diversos bens e serviços. Apesar disso, cerca de $77 \%$ da população moçambicana (23 milhões de pessoas) não têm acesso a ERN, o que se impõe a procura/adoção de mecanismos que potencializam o aproveitamento de diversas fontes de energias renováveis disponíveis localmente.

Neste contexto, a tecnologia e os resultados da presente pesquisa podem constituir alternativa, tanto para redução da pobreza energética que assola a maior parte da cidade de Nampula e Moçambique no geral, como para geração descentralizada de eletricidade com baixos impactos ambientais, usando-se recursos disponíveis localmente, o que torna esta tecnologia, acessível e sustentável.

Consta como as principais limitações na expansão dos serviços energéticos ligados à rede e no desenvolvimento de projetos de energias renováveis em Moçambique, o rápido declínio do ambiente macroeconômico, caracterizado pela alta inflação e desvalorização da moeda nacional, a alta taxa de pobreza e baixo poder de compra, a insegurança, falta de serviços de logística e de fornecimento deficientes e pelo fato da maioria da população viver em áreas rurais e remotas (FORTES et al., 2020); NHAMIRE; MOSCA, 2014).

A partir da análise da matriz energética nacional, consta que as tecnologias de energia hídrica, em pequena escala, não apresentam níveis altos de utilização, devido ao elevado custo associado à aquisição, instalação e manutenção dos sistemas hidroelétricos. Porém, a utilização de sistemas energéticos alternativos auxilia na estabilidade da procura e oferta dos bens e serviços energéticos para os diferentes estratos sociais, sobretudo nos mais necessitados. E a utilização de tecnologias de fontes renováveis de energia podem dar respostas às diversas imposições globais sobre o meio ambiente e a sustentabilidade.

Na dimensão econômica (tabela 9), a geração de eletricidade a partir de turbinas Kaplan construídas por materiais alternativos pode ser uma ótima oportunidade de negócio para microempreendedores no ramo de energia hídrica, aos fornecedores das componentes do sistema, aos revendedores e à população em geral. Além disso, deve-se melhorar a utilização de recursos e tecnologias locais, criar soluções de baixo custo e desenvolver pequenas empresas para conceber, fabricar, distribuir, instalar e gerir as aplicações.

Em termos político e legal, Moçambique tem leis, políticas e regulamentos do setor energético bastante recentes, porém o quadro legal ainda carece de mecanismos para compatibilizar o atual estágio das tecnologias energéticas, as necessidades do País:

- A instabilidade sociopolítica e econômica não permite a realização de todos os programas para a expansão da ERN;

- Não existe política públicas que regula e compensa financeiramente para os pequenos e micros geradores transferirem os excedentes de energia geradas em sistemas off grid para os sistemas on grid e vice-versa;

- A política tarifária não reflete os custos do investimento e muito menos os de exploração da empresa, sendo estes, nalguns casos, suportados em pequena porção pelo orçamento geral do Estado, dos doadores e financiadores externos;

Além destas barreiras genéricas associadas ao país, os promotores de energias renováveis têm ainda que lidar com barreiras específicas ao setor da energia relacionadas com o perfil energético nacional, o enquadramento económico e financeiro, o nível de educação e formação, para além da falta de experiências, a nível institucional e técnico, na geração de energia hidrelétrica, em pequena escala, em sistemas isolados off grid ou on grid.

Por isso, para usufruir dos benefícios e massificar o uso das tecnologias energéticas alternativas no atendimento das necessidades dos consumidores, sobretudo os rurais e suburbanos, não abrangidos pela ERN, estas tecnologias devem ser acessíveis, de baixo custo e gerar uma potência necessária para uso doméstico. Apesar das perdas hidráulicas e mecânicas (Fig. 5), o sistema apresenta-se mais eficiente que outras fontes de eletricidade, usadas pelas comunidades, sobretudo, as biomassas tradicionais, velas, sistemas à petróleo, pilhas alcalinas e as baterias chumbo/ácido. Estes últimos sistemas devem ser recarregados periodicamente ou descartados após a utilização, constituindo, deste modo, um dos maiores problemas socioambientais. 
Diante disso, a criação e desenvolvimento de tecnologias de aproveitamento de energias limpas e renováveis, em pequena escala, poderá contribuir no desenvolvimento socioambiental e socioeconômico da comunidade. Estes PCHs podem ser desenvolvidos para gerar eletricidade em sistemas on grid e off grid, gerando, em sistemas acoplados, o equivalente às grandes centrais, sem necessidade de construir linhas de transporte e distribuição de eletricidade.

\section{CONCLUSÃO}

A construção de um sistema hidrelétrico com turbina Kaplan usando material alternativo e de baixo custo é sustentável, nas dimensões social, ambiental e econômica, constituindo uma alternativa viável para geração descentralizada de eletricidade, sobretudo para eletrificação rural e em comunidades isoladas não abrangidas pela ERN.

O sistema construído apresenta condições para a geração de eletricidade nos pequenos potenciais hídricos para acionar aparelhos de baixa potência, de uso comum e diário das populações, como rádio, televisão, carregadores de celular, lâmpadas e outros. Para além do uso doméstico, o sistema pode ser usado para bombeamento de água, irrigação e piscicultura.

As principais perdas do sistema hidrelétrico estudado foram no gerador e nas engrenagens. Pode-se obter maior rendimento na potência do gerador se adequar às rotações da turbina e do eixo do gerador por meio do uso de engrenagens multiplicadoras de velocidade.

Não se verificou nenhum impacto negativo significativo durante a instalação, teste e desmonte do sistema. Porém, para sistemas permanentes deve-se realizar estudos de impacto ambiental detalhado para controle de possíveis desmoronamento das margens, prejuízos à fauna e à flora locais, e alterações no regime hidráulico do rio.

A instabilidade macroeconômica, a pobreza, o déficit técnico/tecnológico e a falta de uma legislação específica que incentiva os pequenos geradores de eletricidade constitui um fator limitante no desenvolvimento e expansão das tecnologias de geração descentralizada de energia hídrica em Moçambique.

Em suma, sistema hidrelétrico com turbina Keplan, construído a partir de materiais alternativos é acessível sustentável sob ponto de vista socioambiental e econômico, para além de gerar uma potência útil nos rios de baixo declive com baixos impactos nocivos ao ambiente. Um conjunto de PCHs pode gerar o equivalente a grandes centrais hidroelétricas.

\section{REFERÊNCIAS}

[1] BARRETO, E. J. F.; PINHO, J. T.; TIAGO, G. L.; RENDEIRO, G.; NOGUEIRA, M.; GONZALEZ, W. A. Pequenos Aproveitamentos Hidrelétricas: Soluções energéticas para a Amazónia. Brasília, DF: Ministério de Minas e Energia, 2008.

[2] BIZAWU, K.; AGUIAR, P. L. M. DE. Energias renováveis e desenvolvimento sustentável: desafios e perspectivas para os Países emergentes. CONPEDI Law Review, v. 2, n. 4, p. 394-411, 2016.

[3] BORBA, M. C. V.; GASPAR, N. F. Um futuro com energia sustentável: iluminando o caminho. Rio de Janeiro, RJ: FAPESP, 2010.

[4] CAUS, T. R.; MICHELS, A. Energia Hidroelétrica: Eficiência na Geração. Tese de pós-graduação em eficiência energética aplicada aos processos produtivos. UFSM e UAB, Camargo, 2017.

[5] DUTRA, A. DA S.; MARQUES, F. V. M. DA S. O uso de energias renováveis como mecanismo de sustentabilidade. X Congresso Nacional de Excelência em Gestão. Anais...Niterói - RJ: CNEG e INOVARSE, 2014

[6] FORTES, A. G.; RAIMUNDO, B.; MUTENDA, F. M. Energias renováveis em Moçambique: disponibilidade, geração, uso e tendências futuras. Revista Brasileira Multidisciplinar, v. 23, n. 1, p. 7-27, 2020.

[7] GELLER, M. T. B. Análise do ciclo de vida da Usina Hidrelétrica de CURUA - UNA. Tese de Doutorado em Sociedade Natureza e Desenvolvimento. Universidade Federal do Oeste do Pará. Santarem - PA, 2016.

[8] GIELENA, D.; BOSHEllA, F.; SAYGINB, D.; BAZILIANC, M. D.; WAGNERA, N.; GORINIA, R. The role of renewable energy in the global energy transformation. Energy Strategy Reviews, v. 24, p. 38-50, 2019.

[9] GOMES, V. P. R. G.; CAMIOTO, F. DE C. Análise de viabilidade econômica da implementação de um sistema de energia fotovoltaica nas residências uberabenses. XXXVI Encontro Nacional de Engenharia de Produção. Anais...João Pessoa/PB, Brasil: Associação Brasileira de Engenharia de Produção, 2016 
[10] GUEIFÃO, C.; ANDRÉ, J. NÓBREGA, R.; CARANOVA, R.; SANTOS, J.; ANDRÉ, S.; ...; FALCÃO, D. Atlas das energias renováveis de Moçambique: Recursos e projectos para produção de electricidade. 1. ed. Maputo: Gesto-Energia, S.A., 2013.

[11] HEINBERG, R. Five axioms of sustainability. Disponível em: <http://richardheinberg.com/178-five-axiomsof-sustainability>. Acesso em: 30 abr. 2020

[12] INE. IV Recenseamento geral da população e habitação: Resultados definitivos Moçambique. Maputo: Instituto Nacional de Estatística, 2019.

[13] JÚNIOR, R. L. S. Projeto conceitual de uma turbina a ser utilizada na usina hidrelétrica externa de Henry Borden. Projeto de graduação em Engenharia Mecânica. Universidade Federal do Rio de Janeiro. Rio de Janeiro - RJ, 2013

[14] MAE. Perfil do distrito de Nampula - Província de Nampula. Maputo: Ministério da Administração Estatal, 2014.

[15] MOÇAMBIQUE. Lei 20/1997, de 1 de outubro. Lei do ambiente. Maputo: Boletim da República de Moçambique, 1997a.

[16] MOÇAMBIQUE. Lei de Electricidade, Lei no 21/97 de 1 de outubro. Maputo: Boletim da República de Moçambique, 1997b.

[17] MOÇAMBIQUE. Resolução no 5/98 de 3 de março. Política energética. Maputo: Boletim da República de Moçambique, 1998.

[18] MOÇAMBIQUE. Decreto no 8/2000 de 20 de abril. Regulamento que estabelece as competências e os procedimentos relativos à atribuição de concessões de produção, transporte, distribuição e comercialização de energia eléctrica, bem como a sua importação e exportação. Maputo: Boletim da República de Moçambique, 2000.

[19] MOÇAMBIQUE. Decreto no 45/2004 de 29 de setembro: Regulamento sobre o processo de avaliação de impacto ambiental. Maputo: Boletim da República de Moçambique, 2004.

[20] MOÇAMBIQUE. Decreto no 42/2005 de 29 de novembro. Regulamento que estabelece normas referentes à rede nacional de energia eléctrica. Maputo: Boletim da República de Moçambique, 2005.

[21] MOÇAMBIQUE. Resolução 62/2009, de 14 de outubro. Política de Desenvolvimento de Energias Novas e Renováveis. Maputo: Boletim da República de Moçambique, 2009a.

[22] MOÇAMBIQUE. Estratégia do sector de energia. Resolução no 10/2009 de 4 de Junho. Maputo: Boletim da República de Moçambique, 2009b.

[23] MOÇAMBIQUE. Estratégia de desenvolvimento de energias novas e renováveis para o período 2011-2025. Maputo: Ministério de Energia, 2011. p 1-41.

[24] MOÇAMBIQUE. Decreto n 58/2014. Regulamento que estabelece o regime tarifário para as energias novas e renováveis. Maputo: Boletim da República de Moçambique, 2014a.

[25] MOÇAMBIQUE. Diploma Ministerial no 184/2014 de 12 de novembro. Código da rede eléctrica nacional. Maputo: Boletim da República de Moçambique, 2014b.

[26] MOÇAMBIQUE. Decreto no 10/2016, de 25 de abril. Regulamento de Licenças para Instalações Eléctricas (RLIE). Maputo: Boletim da República de Moçambique, 2016.

[27] NHAMIRE, B.; MOSCA, J. Electricidade de Moçambique: mau serviço, não transparente e politizada. Maputo: Centro de Integridade Pública de Moçambique, 2014.

[28] ONU. A Agenda 2030 para o Desenvolvimento Sustentável. Disponível em: <http://www.agenda2030.org.br/sobre/>. Acesso em: 19 abr. 2019.

[29] VILA, C. U. Planejamento Energético e as políticas públicas: Aspectos conceituais e metodológicos. In: PEREIRA, T. C. G. (Ed.). Energias Renováveis: Políticas Públicas e Planejamento Energético. Curitiba - PR: COPEL, 2014. p. $24-45$.

[30] YAMACHITA, R. A. Determinação de perdas e rendimento em motores elétricos empregando termografia infravermelha. Tese de Doutorado em Engenharia Elétrica. Universidade Federal de Itajubá, Itajubá - MG, 2013. 


\section{Capítulo 15}

Análise do perfil da pegada hídrica cinza da rizicultura no perímetro irrigado Betume, Neópolis SE

Camilo Rafael Pereira Brandão

Inajá Francisco de Sousa

Resumo: A água é um recurso essencial e apenas 2,5\% é caracterizada como água doce. O conceito de Pegada Hídrica (PH) foi proposto por Hoekstra em 2002, sendo um indicador de uso direto e indireto da água e dividida em três componentes no qual a Pegada Hídrica Cinza é definida como o volume de água necessário para assimilar a carga de poluentes nos corpos hídricos. Portanto, o objetivo deste trabalho foi contabilizar a PH do componente cinza da rizicultura no baixo São Francisco para os anos de 2016, 2017 e 2018, analisando a evolução do perfil desta pegada cinza para a localidade. 0 estudo foi realizado no perímetro irrigado Betume no município de Neópolis - SE e a contabilização está de acordo com o cálculo proposto por Hoekstra et al., (2011) a partir de dados coletados na região e na literatura específica. A partir dos resultados obtidos demostram um perfil de ascensão da PH cinza da rizicultura na região no qual os corpos hídricos locais até o momento conseguem assimilar a curto prazo os efluentes dos produtos químicos lançados de acordo com o CONAMA 357ํ. Por fim, observa-se que o lançamento de efluentes da rizicultura diretamente no rio São Francisco e rio Betume compromete a qualidade da água que possui usos múltiplos na região.

Palavras-Chave: Agricultura; Qualidade da água; Gerenciamento de Recursos Hídricos. 


\section{INTRODUÇÃO}

De toda água existente no planeta terra, 97,5\% está concentrada nos oceanos, a água doce representa apenas 2,5\% sendo distribuída entre os processos agrícolas, industriais e humanos (TUNDISI; TUNDISI, 2011). 0 uso deste recurso mundialmente é dividido em setores, sendo $70 \%$ para agricultura no qual se destina a irrigação de plantações, $20 \%$ para os processos industriais e $10 \%$ para o consumo humano (MILLER JR, 2014). Sua gestão envolve a preservação das nascentes fornecedoras através do manejo adequado dos corpos d'água e é administrada por diferentes esferas do poder público e organizações privadas (RIBEIRO, 2014).

Foi instaurado no Brasil, através da Lei 9.433/97, a Política Nacional dos Recursos Hídricos (PNRH) e o Sistema Nacional de Gerenciamento de Recursos Hídricos (SINGREH) no qual tem como prerrogativas equacionar a demanda crescente das águas destinadas ao crescimento urbano, agrícola, industrial, assim como, o avanço na degradação de rios e lagos (TUNDISI; TUNDISI, 2011).

Com a implementação destes dois marcos hídricos no país, foi aberto um leque de possibilidades para uma gestão mais eficiente e participativa no qual dispõe de cinco instrumentos, destacamos aqui, o Enquadramento dos Corpos Hídricos no qual são referências para o checkup da saúde dos rios, englobando todos os elementos que medem a qualidade da água a partir de um monitoramento contínuo (COSTA et al., 2019; BRANDÃO; SOUSA, 2020), e a Outorga de Direitos de Uso dos Recursos Hídricos no qual deve ser vista como um instrumento de distribuição de água entre os mais diversos usos dentro de uma bacia hidrográfica, objetivando as necessidades socioambientais e econômicas, diminuindo os conflitos entre os usuários e possibilitando o atendimento para futuras demandas no uso da água (OLIVEIRA; FACCIOLI, 2011).

Portanto, a crescente demanda por alimentos para suprir as necessidades da população global vem acelerando os processos de degradação da qualidade dos recursos hídricos mundiais, buscando contornar este atual cenário, o conceito da Pegada Hídrica (PH) foi proposto em 2002, sendo um indicador do uso direto e indireto da água por consumidor ou produtor, contabilizando e apresentando uma ferramenta de gestão eficiente de recursos hídricos pelos setores produtivos (ALDAYA; MUNÕZ; HOEKSTRA, 2010). É um importante indicador na prestação de serviços ecossistêmicos, apresentando soluções para contornar os efeitos da escassez hídrica a nível local e global (GIACOMIN; OHNUMA JR, 2012).

Deste modo, a PH possui três componentes para a contabilização da água doce consumida durante os processos, sendo estes industriais ou agrícolas, no qual a $\mathrm{PH}$ verde é o consumo da água de chuva armazenada no solo ou vegetal, a PH azul é o consumo de água disponível em uma bacia hidrográfica e incorporada na produção de um produto (HOEKSTRA et al., 2011). Hoekstra et al., (2011) define a PH cinza como o volume de água necessário para assimilar a carga de poluentes a partir de concentrações naturais e padrões da água existentes, sendo estes, a qualidade da água que compõe o corpo receptor de acordo com as normas referentes as concentrações máximas permitidas, mostrando a capacidade de assimilação dos corpos receptores para diluir os poluentes, a contabilização deste componente é importante por indicar o nível de poluição na cadeia de produtos e processos.

A utilização da PH pode auxiliar nos instrumentos de gestão implementados pela PNRH, enriquecendo o entendimento e ajudando na gestão dos recursos hídricos a nível local em diferentes partes do Brasil, este conceito já vem sendo amplamente aplicado internacionalmente e começa a ser utilizado nacionalmente (CLASSE; RIBEIRO; ROCHA, 2013). Portanto, as estratégias tradicionais de gestão da água focadas apenas nas transferências físicas dos recursos hídricos podem ser complementadas por estudos adicionais sobre indústrias e produtos agrícolas que consomem intensivamente este recurso, buscando melhorar a escassez através do ajuste do consumo da água por estes setores (XU; CHUNHUI, 2020).

A produção de arroz no Estado de Sergipe se concentra em várzeas inundáveis do baixo São Francisco usado nos perímetros irrigados, esta cultura possui grande importância na geração de empregos e mãode-obra familiar na região, sofre com a baixa do preço e a limitação na disponibilidade hídrica. Andrade (2016) discorre sobre a importância dos projetos de irrigação existentes neste estado, no qual são referências apesar da atual fragilidade devido à baixa vazão do rio São Francisco.

0 mercado de produtos agroquímicos brasileiro teve uma alta expansão na última década sendo o dobro do ritmo do mercado global, fazendo com que o país se encontre em primeiro lugar no ranking mundial (MENDES et al., 2019). Mesmo possuindo uma legislação para o uso dos produtos agroquímicos e seu descarte final, o lançamento de efluentes gerados sem tratamento diretamente nos rios e lagos afetam a qualidade dos corpos hídricos e pode comprometer os abastecimentos para gerações futuras. 
A abordagem da PH reflete mudanças em estratégias no manejo da água, no qual enfatiza uma produção baseada na valoração, sendo assim, um importante instrumento em termos de governança da água (CHAPAGAIN; TICKNER, 2012). Diante do contexto exposto, este trabalho objetivou analisar o perfil de evolução da pegada hídrica do componente cinza da rizicultura no baixo São Francisco nos anos de 2016, 2017 e 2018.

\section{METODOLOGIA}

O Perímetro Irrigado Betume é localizado entre os municípios de Neópolis, Ilha das Flores e Pacatuba no baixo São Francisco, no estado de Sergipe - Brasil (Figura 1), e a rizicultura é a principal atividade e seu sistema baseia-se na irrigação por inundação, possuindo cerca de 148km de redes de irrigação. Possui 2.865ha irrigáveis e se encontra em operação desde 1978 (CODEVASF, 2005; BRASIL, 2014). Sua administração é feita pela Companhia de Desenvolvimentos dos Vales do São Francisco e do Parnaíba no qual contempla a agricultura familiar (CODEVASF) (BRITTO, 2015).

FIGURA 1. Localização do perímetro irrigado Betume a nível estadual e regional.

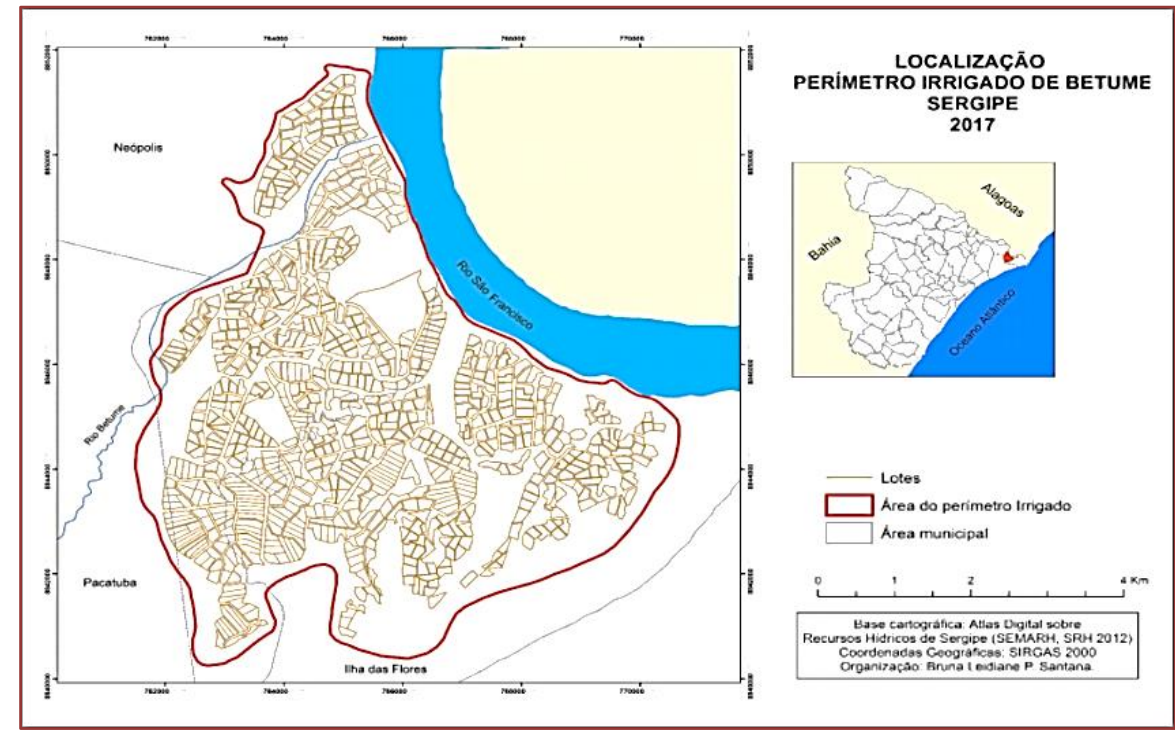

Organização: Leidiane P. Santana, 2017

O levantamento das informações acerca da produtividade de arroz nos anos de 2017, 2018 e 2019 , foi realizado junto à CODEVASF em um lote de aproximadamente 3,9 hectares (Tabela 1). A água proveniente das bombas instaladas nas proximidades do rio São Francisco e do rio Betume são distribuídas via canais que interligam os lotes.

TABELA 1. Produtividade do lote da rizicultura (ton) nos anos de 2016, 2017.

\begin{tabular}{|c|c|c|c|}
\hline Ano & 2016 & 2017 & 2018 \\
\hline Produtividade (ton $/ \mathrm{ha}^{-1}$ ) & 9.850 & 8.750 & 8.000 \\
\hline
\end{tabular}

Fonte: CODEVASF (2018)

Apegada hídrica cinza foi calculada multiplicando a taxa de aplicação de agroquímicos por hectare (TAQ, $\mathrm{Kg} / \mathrm{ha}$ ), pela fração de lixiviação/escoamento $(\alpha)$, dividida pela concentração máxima aceitável $\left(\mathrm{C}_{\max }\right)$, menos a concentração natural do poluente considerado $\left(\mathrm{C}_{\text {nat }}\right)$, dividida então pela produtividade da cultura (Y ton/ha), de acordo com a Eq 1. 


$$
\text { PHcinza }=\frac{(\alpha \times T A Q) /(\operatorname{Cmax}-\text { Cnat })}{\mathrm{Y}}
$$

A fração de lixiviação adotada neste estudo está de acordo com Chapagain e Hoekstra (2010) que é de 5\%. Os dados referentes a taxa de aplicação de fertilizantes para a cultura do arroz estão de acordo com Bayer et al. (2012), no qual o valor é 30, o valor da concentração máxima aceitável para o poluente se encontra dentro dos limites enquadrados pelo CONAMA N ${ }^{\circ} 357 / 05$ para o lançamento de efluentes $\left(20 \mathrm{mg} \mathrm{L}^{-1}\right) .0^{2}$ poluente mais crítico considerado nesta pesquisa é o nitrogênio $\left(\mathrm{N}_{2}\right)$ e o valor da concentração natural no corpo hídrico foi igual a zero de acordo com Hoekstra et al. (2011).

\section{RESULTADOS E DISCUSSÃO}

A pegada hídrica cinza é um indicador do volume de água necessário para assimilar uma carga poluente que atinge um corpo de água, sendo um indicador da apropriação dos recursos hídricos por meio da poluição, avaliando o uso sustentável, eficiente e equitativo da água (FRANKE; BOYACIOGLU; HOEKSTRA, 2013). Chapagain e Hoekstra (2011) estimaram a média da PH global para a rizicultura entre 2000 e 2004 , o valor médio no Brasil para a depuração/diluição dos poluentes desta atividade nos corpos hídricos é de $61 \mathrm{~m}^{3}$ ton $^{1}$

Os resultados obtidos durante a realização desta pesquisa demonstram um perfil em ascensão da PH cinza na rizicultura do baixo São Francisco (Figura 2). Os corpos hídricos locais até o momento conseguem assimilar os efluentes de produtos agroquímicos lançados no rio sem um tratamento prévio após o fim do ciclo da plantação.

O valor da PH cinza saltou de $11,89 \mathrm{~m}^{3} /$ ton (2016) para $13,8 \mathrm{~m}^{3} /$ ton (2017), um aumento de cerca de $16 \%$. Se calcularmos esta porcentagem no período entre 2016 e 2018 (14,6 $\mathrm{m}^{3} /$ ton), o aumento é de aproximadamente $22 \%$, um acréscimo de $6 \%$ entre 2016 e 2017. A longo prazo, caso este ritmo continue o mesmo, é possível projetar um aumento de até $18 \%$ até 2021.

É necessário o monitoramento constante da qualidade da água na região já que o seu uso é voltado para a agricultura e o consumo humano e também o uso eficiente de sistemas de tratamentos que proporcionem o lançamento de efluentes com menores cargas poluentes e, consequentemente, a diminuição na PH cinza da região.

FIGURA 2. Curva de crescimento da pegada hídrica cinza do arroz.

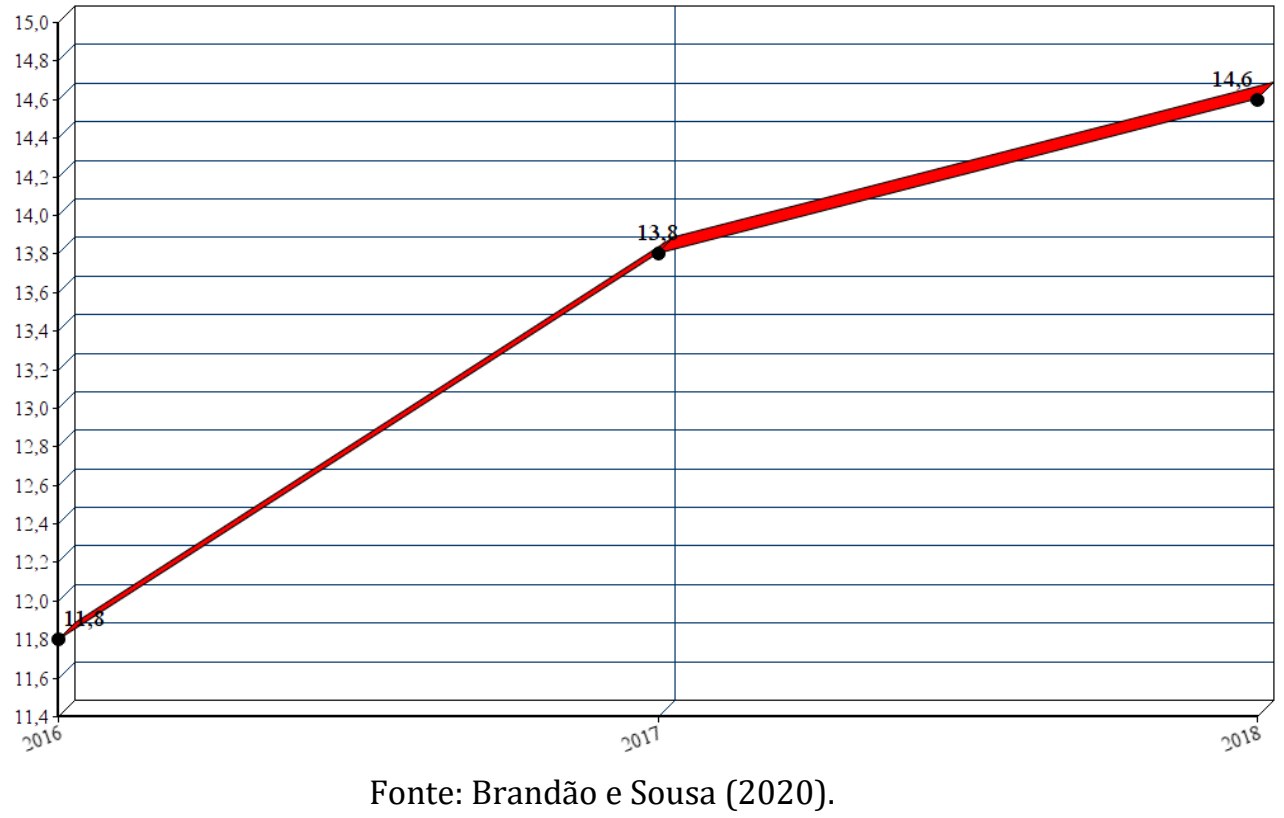

Fonte: Brandão e Sousa (2020). 
Britto et al., (2016) avaliou a qualidade da água utilizada no cultivo do arroz no baixo São Francisco e os impactos da produção na qualidade da água, comprovando que as concentrações indicam interferências antrópicas no ambiente aquático no qual se destacam principalmente durante a colheita do arroz quando as águas represadas são drenadas para o rio, relatando a ocorrência de coliformes termotolerantes no qual indicam que a água está contaminada, provavelmente devido a efluentes domésticos ou agropastoris.

Grande parte de pesquisas voltadas para a PH do cultivo do arroz são realizados no continente asiático, a China se destaca, sendo o maior produtor de arroz do mundo. Xinchun et al., (2018) realizou a avalição da PH do arroz irrigado no leste da China no qual a PH cinza corresponde a 40,9\% da PH total entre os anos de 2011 e 2014. Rodriguez, Galarreta e Kruse (2015) analisaram PH da batata na região pampa da Argentina, no qual demonstrou que a PHcinza corresponde a 43,6\% da PH total do desenvolvimento da cultura, isso implica no volume de água necessário para assimilar os fertilizantes nitrogenados lixiviados impactando de maneira considerável na qualidade da água daquela localidade.

É importante lembrar que os recursos hídricos a nível global sofrem depreciação e uso predatório e as consequências por este modo insustentável de utilização é refletida na escassez hídrica a nível local e global prejudicando os ecossistemas aquáticos. Pedde, Kroeze e Rodrigues (2013) avaliaram o crescimento populacional e seus impactos na escassez hídrica da América do Sul no futuro, concluindo que o Nordeste do Brasil será uma das regiões mais afetadas, portanto, é necessário a mitigação da PHcinza projetando eliminar ou reduzir o uso de substâncias químicas nos cultivos, tendo como opção a agricultura orgânica. Na região do baixo São Francisco já existem agricultores optando por este tipo de produção.

\section{CONSIDERAÇÕES FINAIS}

O cálculo da pegada hídrica cinza no desenvolvimento da cultura do arroz no perímetro irrigado Betume apresenta um resultado significativo em virtude da tendência de crescimento a nível local. 0 estudo demonstra que o lançamento dos efluentes da rizicultura diretamente no rio São Francisco e rio Betume sem tratamento compromete a qualidade da água disponível para usos múltiplos na região.

Dois dos cincos instrumentos de gestão da Política Nacional dos Recursos Hídricos (PNRH) juntamente com a contabilização da $\mathrm{PH}$ azul, verde e cinza podem contribuir para uma gestão responsável e sustentável das águas, sendo eles, o enquadramento dos corpos de água, assegurando o acesso a água de qualidade e medidas preventivas para poluição, e a cobrança pelo uso, já que é necessário voltar a atenção ao valor cobrado para os irrigantes da região, criando pactos em comum acordo para a preservação dos recursos hídricos locais.

Por fim, observa-se o crescimento das discussões a respeito da escassez hídrica na comunidade em geral, sendo a pegada hídrica o indicador de sustentabilidade extremamente necessário na formulação de políticas e ações que visem a gestão dos recursos hídricos a nível mundial.

\section{AGRADECIMENTOS}

0 presente trabalho foi realizado com apoio da agência de fomento: Coordenação de Aperfeiçoamento de Pessoal de Nível Superior - BRASIL (CAPES) -- Número do Processo: 88881.157414/2017-01 Número do Auxílio: 1968/2017.

\section{REFERÊNCIAS}

[1] ALDAYA, M. M.; MUÑOZ, G.; HOEKSTRA, A. Y. Water footprint of cotton, wheat and rice production in Central Asia. UNESCO-IHE, 2010

[2] ANDRADE, C. B.; Diagnostico da rizicultura na foz do rio São Francisco sob a perspectiva de um modelo sustentável de gestão. 159f. Tese de Doutorado (Doutorado em Desenvolvimento e Meio Ambiente), Universidade Federal de Sergipe, 2016.

[3] BRANDÃO, C. R. P; SOUSA, I. F.; Contabilização da pegada Hídrica azul, verde e cinza da rizicultura no perímetro irrigado Betume - SE. 2020. 128f. Dissertação (Mestrado em Desenvolvimento e Meio Ambiente) Universidade Federal de Sergipe, 2020. 
[4] BRASIL. Resolução n. o 430, de 13 de maio de 2011. Dispõe sobre as condições e padrões de lançamento de efluentes, complementa e altera a Resolução n. o 357, de 17 de março de 2005, do Conselho Nacional do Meio Ambiente-CONAMA. Diário Oficial da União. 2011.

[5] BRITTO, F. B.; Monitoramento e modelagem da qualidade da água e agroquímicos em corpos hídricos no Baixo São Francisco sergipano. 165f. Tese de Doutorado (Doutorado em Desenvolvimento e Meio Ambiente), Universidade Federal de Sergipe, 2015.

[6] BRITTO, F. B.; SILVA, T. M. M.; VASCO, A. N.; NETTO, A. O. A.; CARVALHO, C. M. Impactos da produção do arroz inundado na qualidade da água do Rio Betume, Sergipe. Revisa Agropecuária Técnica, v. 37, p. 44-54, 2016.

[7] CHAPAGAIN, A. K.; HOEKSTRA, A. Y. The blue, green and grey water footprint of rice from production and consumption perspectives. Ecological Economics, v. 70, n. 4, p. 749-758, 2011.

[8] CHAPAGAIN, A; TICKNER, D. Pegada Hídrica: evolução do conceito e sua utilidade na prática. In: EMPINOTI, V; JACOBI, P.R.(Org.). Pegada Hídrica: inovação, corresponsabilização e os desafios de sua aplicação. São Paulo: Annablume, 2012.

[9] CLASSE, T. M., RIBEIRO, C. B. M, ROCHA, W. S. D. Análise da metodologia da Pegada Hídrica como possível ferramenta na gestão pública dos recursos hídricos. III Simpósio de Recursos Hídricos da Bacia do Rio Paraíba do Sul. Universidade Federal de Juiz de Fora. 2016.

[10] COSTA, D. A.; ASSUMPÇÃO, R. S. F. V.; AZEVEDO, J. P. S.; SANTOS, A. Dos instrumentos de gestão de recursos hídricos - o Enquadramento - como ferramenta para reabilitação de rios. Saúde em Debate, v. 43, p. 35-50, 2020.

[11] FRANKE, N. A; BOYACIOGLU, H; HOEKSTRA, A. Y. Grey Water Footprint Accounting: Tier 1 supporting guidelines. Delft: Unesco-lhe.

[12] GIACOMIN, G. S; JR, A. A. O.; Análise de resultados de pegada hídrica por países e produtos específicos. Revista Eletrônica em Gestão, Educação e Tecnologia Ambiental, v. 8, n. 8, p. 1562-1572, 2012.

[13] HOEKSTRA, A. Y.; CHAPAGAIN, A. K.; ALDAYA, M.; MEKONNEN, M. M. Manual de Avaliação da Pegada Hídrica: Estabelecendo o Padrão Global. Water Footprint Network, 2011. 191p.

[14] MENDES, C. R. A.; MENDES, C. E. P.; SANTOS, F. S.; LUZ, K. S. R.; SANTANA, L. P. AGROTÓXICOS: principais classificações utilizadas na agricultura brasileira-uma revisão de literatura. MAESTRIA, n. 17, p. 95-107, 2019.

[15] MILLER JR, G.T. Ciência Ambiental. Tradução All Tasks. Revisão Técnica Wellington Braz Carvalho. São Paulo: Cengage Learning, 2014.

[16] OLIVEIRA, M. S. S.; FACCIOLI, G. G. Outorga de direito de recursos hídricos na bacia hidrográfica do rio Sergipe. 2011. 114 f. Dissertação (Pós-Graduação em Desenvolvimento e Meio Ambiente) - Universidade Federal de Sergipe, São Cristóvão, 2011.

[17] PEDDE, Simona; KROEZE, Carolien; RODRIGUES, Lineu N. Escassez hídrica na América do Sul: situação atual e perspectivas futuras. XX Simpósio Brasileiro de Recursos Hídricos, 2013.

[18] RIBEIRO, C.S. Pegada Hídrica e Água Virtual: Estudo de caso da manga no Submédio doVale do São Francisco, Brasil. 2014. 79f. Dissertação (Mestrado em Economia) - Falculdade de Economia, Universidade Federal da Bahia, 2014.

[19] RODRIGUEZ, C. I., GALARRETA, V. R.; KRUSE, E. E. Analysis of water footprint of potato production in the pampean region of Argentina. Journal of Cleaner Production, 90, 91-96. 2015.

[20] TUNDISI, J. G.; TUNDISI, M. T.; Recursos hídricos no século XXI. Oficina de Textos, 2011.

[21] XINCHUN, C.; MENGYANG W.; RUI S.; LA, Z.; DAN, C.; GUANGCHENG, S.; XIANGPING, G.; WEIGUANG, W.; SHUHAI, T.l. Water footprint assessment for crop production based on field measurements: A case study of irrigated paddy rice in East China. Science of the Total Environment, v. 610, p. 84-93, 2018.

[22] XU, M.; LI, C.; The Concepts of Virtual Water and Water Footprint. In: Application of the Water Footprint: Water Stress Analysis and Allocation. Springer, Singapore, 2020. p. 9-16. 


\section{Capítulo 16}

Estudo de um processo de baixo custo para a separação da emulsão óleo-água de fluido de corte emulsionável

Joyce Aparecida Pifano de Oliveira

Paulo Cézar Gonçalves

Kátia Valéria Marques Cardoso Prates

Janksyn Bertozzi

Janaina Fracaro de Souza Gonçalves

Resumo: As atividades de usinagem de peças dependem do uso de fluidos de corte que, após o seu uso, tornam-se passivos ambientais perigosos. No lugar de descartar a água que compõe o fluido de corte degradado, pode-se buscar reutilizar esta água na própria indústria. Dessa forma, o objetivo do presente trabalho foi estudar um processo de baixo custo para a separação da emulsão óleo-água de fluido de corte emulsionável. Para realizar a quebra da emulsão, foi realizado um planejamento estatístico utilizando o Delineamento do Composto Central Rotacional (DCCR) em 15 ensaios em triplicata para avaliar a influência do pH, da concentração de Cloreto de Cálcio e Cloreto de Magnésio. A análise da superfície de resposta da interação Cloreto de Magnésio e pH indicaram que utilizar ou não o cloreto de Magnésio não interfere na quebra da emulsão. Entretanto quando se avalia a interação do Cloreto de Cálcio e pH obtém-se uma interação positiva, indicando que o uso do Cloreto de Cálcio é necessário para que ocorra a quebra da emulsão. Pode-se concluir pelos resultados que o melhor processo de separação do óleoágua do fluido de corte ocorreu no ensaio 12 com pH 9 e 3,67g de Ca.

Palavras-chave: pH; Cloreto de cálcio; Cloreto de magnésio; Fluido de corte emulsionável. 


\section{INTRODUÇÃO}

As indústrias de transformação contribuem para a economia brasileira, representando cerca de $11 \%$ do Produto Interno Bruto (PIB) e registrando altas no saldo de vagas formais de emprego (CAGED, 2019; CNI, 2020). Tais indústrias realizam processos de corte, moagem e forjamento de metais, utilizando fluidos de corte para facilitar estes processos. Esse fluído possui forte estabilidade, por se tratar de uma emulsão, e possui alto consumo de água, óleos e aditivos (HUANG et. al, 2020)

Apesar do aspecto econômico positivo para a economia, existe o aspecto negativo ligado ao grande volume de efluente oleoso gerado. Tal efluente é gerado pois, conforme utilizado, o fluido de corte passa por alterações devido à degradação causada pelo uso e pela ação de microrganismos, perdendo componentes essenciais que garantem a eficiência relacionada às suas funções (PINTO et al., 2011).

Por isso, o desenvolvimento de estratégias economicamente eficientes para tratar águas residuais oleosas são de grande significância para a segurança ambiental e saúde humana (YOU et al, 2020). Utilizando um tratamento adequado, ao invés de descartar a água utilizada no processo de usinagem, a água pode ser reutilizada ou reciclada.

Dessa forma, objetivou-se com esse trabalho estudar um processo de baixo custo para a separação da emulsão óleo-água do fluido de corte, com foco na obtenção da fase aquosa, utilizando diferentes concentrações de Cloreto de Cálcio $\left(\mathrm{CaCl}_{2} \cdot 2 \mathrm{H}_{2} \mathrm{O}\right)$, Cloreto de Magnésio $\left(\mathrm{MgCl}_{2} \cdot 6 \mathrm{H}_{2} \mathrm{O}\right)$ e alterações do $\mathrm{pH}$.

\section{METODOLOGIA}

Os procedimentos experimentais foram realizados na Universidade Tecnológica Federal do Paraná (UTFPR Londrina) utilizando fluido de corte degradado destinado ao descarte, proveniente de uma indústria metal-mecânica da região metropolitana de Londrina-PR.

Para realizar a quebra da emulsão, foi realizado um planejamento estatístico utilizando o Delineamento do Composto Central Rotacional (DCCR) composto por 15 ensaios em triplicata para avaliar a influência da concentração dos sais Cloreto de Cálcio $\left(\mathrm{CaCl}_{2} .2 \mathrm{H}_{2} \mathrm{O}\right)$ e Cloreto de Magnésio $\left(\mathrm{MgCl}_{2} \cdot 6 \mathrm{H}_{2} \mathrm{O}\right)$ e do pH (Tabela 1).

Para a elaboração da superfície de resposta, os sobrenadantes das amostras (fase aquosa) foram coletados, diluídos e varridos em equipamento de Espectrofotometria de absorção no UV-Visível Perkin Elmer, modelo lambda 25, com o comprimento de onda $280 \mathrm{~nm}$, por absorver tanto substâncias que absorvem no visível, como substâncias que não absorvem no visível, gerando um indicativo mais sensível.

Tabela 1- Codificação dos ensaios para o DCCR.

\begin{tabular}{|c|c|c|c|c|c|c|}
\hline Ensaio & $\mathrm{pH}$ & $\mathrm{Ca}$ & $\mathrm{Mg}$ & $\mathrm{pH}$ & $\mathrm{Ca}^{2+}(\mathrm{g})$ & $\mathrm{Mg}^{2+}(\mathrm{g})$ \\
\hline 1 & -1 & -1 & -1 & 6,17 & 0,53 & 1,21 \\
\hline 2 & 1 & -1 & -1 & 11,82 & 0,53 & 1,21 \\
\hline 3 & -1 & 1 & -1 & 6,17 & 3,14 & 1,21 \\
\hline 4 & 1 & 1 & -1 & 11,82 & 3,14 & 1,21 \\
\hline 5 & -1 & -1 & 1 & 6,17 & 0,53 & 7,15 \\
\hline 6 & 1 & -1 & 1 & 11,82 & 0,53 & 7,15 \\
\hline 7 & -1 & 1 & 1 & 6,17 & 3,14 & 7,15 \\
\hline 8 & 1 & 1 & 1 & 11,82 & 3,14 & 7,15 \\
\hline 9 & $-1,41$ & 0 & 0 & 5,00 & 1,83 & 4,18 \\
\hline 10 & 1,41 & 0 & 0 & 13,00 & 1,83 & 4,18 \\
\hline 11 & 0 & $-1,41$ & 0 & 9,00 & 0,00 & 4,18 \\
\hline 12 & 0 & 1,41 & 0 & 9,00 & 3,67 & 4,18 \\
\hline 13 & 0 & 0 & $-1,41$ & 9,00 & 1,84 & 0,00 \\
\hline 14 & 0 & 0 & 1,41 & 9,00 & 1,84 & 8,36 \\
\hline 15 & 0 & 0 & 0 & 9,00 & 1,84 & 4,18 \\
\hline
\end{tabular}

Fonte: Pifano, 2017 (alterado pelo autor) 


\section{RESULTADOS E DISCUSSÃO}

Na Figura 1 pode-se visualizar as superfícies de resposta obtidas por meio do DCCR.

Figura 1 - Superfícies de resposta obtidas a partir da fase aquosa proveniente da quebra da emulsão óleoágua do fluido de corte.

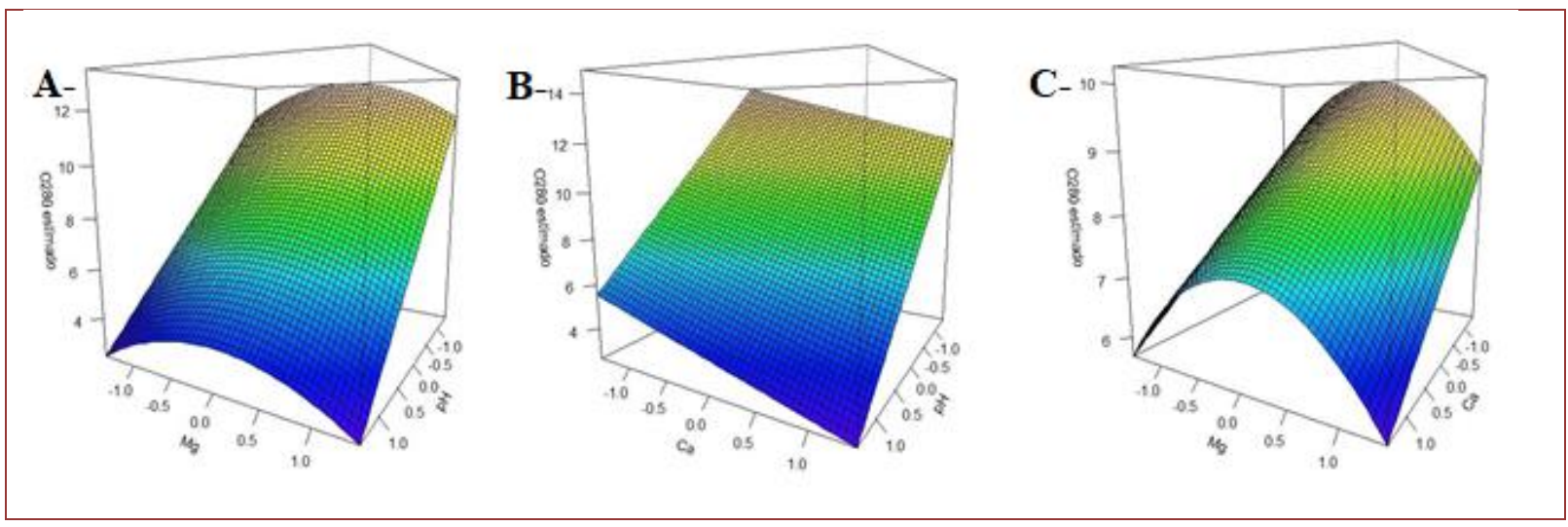

Legenda: A- em função do pH e Mg. B- em função do pH e Ca e C- em função do Ca e Mg.

Como nas superfícies encontradas o resultado procurado eram os valores mínimos de absorção, mostrando que a fase aquosa foi limpa de óleos e reagentes, pode-se observar na Figura 1-A que a interação do pH com o Cloreto de Magnésio possui os pontos de ótimo nos ensaios 13 e 14. Esse resultado demonstra que não utilizar o Magnésio tem o mesmo efeito que utilizá-lo na maior concentração, portanto seu uso na quebra da emulsão é dispensável.

Na Figura 1-B tem-se a interação entre o Cloreto de Cálcio e o pH, com variável explicativa $\mathrm{Mg}$ na codificação 0 . Pode-se observar que o ponto ótimo é no ensaio 12, mostrando que essa interação justifica o uso do Cálcio, pois sua não utilização implica em uma limpeza menos eficiente da parte aquosa, no ensaio 11.

Fixando a variável explicativa pH em 0, na Figura 1-C, pode-se observar novamente que o uso ou não do Magnésio implica na mesma limpeza da fase aquosa, enquanto que a utilização do Cálcio é expressiva. No entanto, na faixa de pH 9 a absorbância no espectro é maior em relação as Figuras 1-A e 1-B.

Apesar disso, elevar o pH até 11,82 ou 13 mostrou-se inviável neste trabalho. 0 pH devido a soma do Ca e Mg comportar-se semelhante a um tampão: o $\mathrm{OH}$ é adicionado, mas o $\mathrm{pH}$ não aumenta pois está sendo consumido na precipitação do Ca e Mg.

\section{CONSIDERAÇÕES FINAIS}

A partir dos resultados pode-se perceber que o objetivo do trabalho foi cumprido, com a quebra da emulsão do fluido de corte e obtenção da fase aquosa, e por meio da analise das superfícies de resposta, os melhores resultados foram aqueles referentes ao Ensaio 12. 0 uso do Cloreto de Magnésio não influenciou os resultados. 


\section{REFERÊNCIAS}

[1] CAGED. Síntese do emprego formal. Dez 2019. Dísponível em: http://pdet.mte.gov. br/caged Acessado em : 20 de junho de 2020

[2] CNI. A importância da indústria de transformação para o Brasil. 2020. Disponível em: https://bucket-gw-cnistatic-cms-si.s3.amazonaws.com/media/filer_public/30/28/3028e5bb-a418-481d-997bc631aed82b56/flyer_a_importancia_da_industria_no_brasil_transformacao_marco_2020.pdf/ acessado em 20 de junho de 2020

[3] PIFANO, J. A. Quebra da emulsão óleo-água de fluido de corte degradado. 52f. Trabalho de Conclusão de Curso (Bacharelado em Engenharia Ambiental) - Universidade Tecnológica Federal do Paraná, Londrina, 2017.

[4] PINTO, M. J..Estratégia e viabilidade econômica no processo de regeneração do óleo lubrificante mineral usado em equipamentos industriais. Xxxi encontro nacional de engenharia de produção- Belo Horizonte, 2011

[5] HUANG, Xiangfeng et al. Functional magnetic nanoparticles for enhancing ultrafiltration of waste cutting emulsions by significantly increasing flux and reducing membrane fouling. Journal of Membrane Science, v. 573, p. 7384, 2019.

[6] YOU, Xiaofei et al. Engineering highly effective nanofibrous membranes to demulsify surfactant-stabilized oilin-water emulsions. Journal of Membrane Science, p. 118398, 2020. 


\title{
Capítulo 17
}

Fungos filamentosos em solo de caatinga salinizada no Vale do Submédio São Francisco, Brasil

\author{
Cledson Sandro Barros de Sá \\ Ricardo Kenji Shiosaki \\ Maryluce Albuquerque da Silva Campos \\ Leilyane Conceição de Souza Coelho \\ Antônio Marcos dos Santo
}

Resumo: Salinização do solo é um problema mundial, além de plantas, afeta os microorganismos. Fungos filamentosos são importantes para o solo, pois participam da degradação de matéria orgânica, podendo ser utilizado como bioindicador das condições do solo. 0 objetivo deste trabalho foi avaliar os fungos filamentosos de solo salinizado no Projeto de Irrigação Senador Nilo Coelho (N11), Vale do Submédio São Francisco, em Petrolina, estado de Pernambuco, Brasil. Foram coletadas e analisadas 40 amostras de solo, em duas áreas de Caatinga, salinizada e nativa, nos períodos seco e chuvoso. Para isolamento dos fungos filamentosos 1 grama de cada amostra foi adicionada a $9 \mathrm{ml}$ de solução salina e diluída, inoculadas em placas de Petri contendo meio de cultura, incubadas a $28^{\circ} \mathrm{C}$ durante 8 dias e depois quantificadas as colônias. Maior quantidade de colônias de fungos filamentosos foi observada na Caatinga nativa. A salinização afeta negativamente os fungos filamentosos, refletindo em menor quantidade de colônias.

Palavras-chave: Semiárido; Bioindicador; Fungi. 


\section{INTRODUÇÃO}

O forte acúmulo de sais solúveis na superfície do solo resulta no processo conhecido como salinização do solo. Este processo tem forte ocorrência em regiões de clima árido e semiárido, onde as taxas de evaporação são altas e as chuvas muito reduzidas, tornando-se, assim, um grande problema em diversos países. Yan et al. (2018) afirmam que esse processo é um dos mais sérios problemas de deterioração dos solos no mundo. No Brasil, esse problema tem sido muito frequente na região Nordeste, devido ao clima semiárido. Este processo afeta o solo, as plantas e os micro-organismos presentes no solo (WU et al. 2015).

Dentre os micro-organismos afetados estão os fungos filamentosos, que possuem ampla distribuição nos mais diversos substratos, onde exercem diversas funções. Alguns são encontrados parasitando e outros são saprófitos ou formam associação mutualística com cianobactérias, algas ou plantas (OLIVEIRA et al. 2013). Haliru et al. (2018) afirmam que os fungos filamentosos são constituídos por anamorfos cosmopolitas como: Penicillium e Aspergillus e outros representantes dos filamentosos são Mucor $e$ Trichoderma. Os fungos filamentosos mais tolerantes a solos salinizados são representados por fungos da ordem Eurotiales (HALIRU et al. 2018).

Diante da importância desses micro-organismos para o ambiente e do potencial de utilização destes como indicadores de qualidade do solo, este trabalho se propõe a investigar a seguinte questão: a salinidade influencia a presença de fungos filamentosos na Caatinga no semiárido brasileiro? A hipótese que norteia este trabalho é a de que a salinidade afeta negativamente a presença de fungos filamentosos.

Desta forma, o objetivo do presente trabalho foi avaliar os fungos filamentosos, nos períodos seco e chuvoso, em solos de Caatinga salinizada e Caatinga nativa não salinizada, no Projeto de Irrigação Senador Nilo Coelho (N11), no Vale do Submédio São Francisco, município de Petrolina, Pernambuco, Brasil.

\section{METODOLOGIA}

Período e área de coleta: 0 solo foi coletado nos períodos seco e chuvoso (agosto de 2017 e fevereiro de 2018 , respectivamente) em duas áreas: área de Caatinga salinizada $\left(9^{\circ} 15^{\prime} 35^{\prime \prime S}\right.$ e $\left.40^{\circ} 24^{\prime} 01^{\prime \prime} \mathrm{W}\right)$ e área de Caatinga nativa adjacente $\left(9^{\circ} 15^{\prime} 18.41^{\prime \prime S}\right.$ e $\left.40^{\circ} 23^{\prime} 38.67 " \mathrm{~W}\right)$, ambas localizadas no núcleo irrigado de moradores 11 (N11), área agrícola pertencente ao Projeto de Irrigação Senador Nilo Coelho, município de Petrolina Pernambuco, Brasil (Semiárido). A área salinizada sofreu uma inundação no ano de 2004, resultando num processo de salinização do solo com o decorrer do tempo. A área salinizada ocupa cerca de $0,8 \%$ do N11, nesse local apenas foram encontradas poucas plantas ainda vivas e muitos troncos de árvores mortas.

Material coletado: Foi constituído de 40 amostras simples de solo, sendo 20 amostras na área salinizada e 20 amostras na área de Caatinga, nos períodos seco e chuvoso. As amostras foram conduzidas ao Laboratório de Micologia, localizado na Universidade de Pernambuco (UPE) Campus Petrolina para avaliação dos fungos filamentosos. Para avaliação da condutividade elétrica (CE), amostras compostas dos solos das duas áreas foram enviadas ao laboratório Plantsoil. $\mathrm{Na}$ área salinizada, no período seco, a CE foi $65,60 \mathrm{dS} / \mathrm{m}$ e no período chuvoso foi de $106,20 \mathrm{dS} / \mathrm{m}$. Na Caatinga, no período seco a CE foi de $0,98 \mathrm{dS} / \mathrm{m}$ e no período chuvoso foi de 1,30 dS/m. Quanto à salinidade, de acordo com a classificação proposta por Richards (1954), o solo da área de Caatinga salinizada foi classificado como extremamente salino (CE >16) e o da área de Caatinga nativa como não salino $(\mathrm{CE}<2)$.

Delineamento experimental: 0 delineamento foi do tipo inteiramente casualizado em arranjo fatorial com dois locais de coleta (área de Caatinga salinizada e área de Caatinga nativa), em dois períodos de coleta (seco e chuvoso), em 10 repetições, totalizando 40 parcelas experimentais.

Isolamento e quantificação dos isolados fúngicos: para isolamento dos fungos filamentosos foi utilizado a técnica de Clark (1965), segundo a qual, 1 grama de cada amostra de solo foi adicionada a $9 \mathrm{ml}$ de solução salina $(0,9 \%)$ e em seguida a suspensão foi diluída nas proporções de $10^{-1}, 10^{-2}, 10^{-3}$ e $10^{-4}$, em seguida inoculadas em placas de Petri contendo meio de cultura: Yeast Malt Agar (YMA), acrescido de antibiótico (cloranfenicol). As placas de Petri foram incubadas a $28^{\circ} \mathrm{C}$ e acompanhadas durante 8 dias. Após o surgimento de colônias, a quantificação dos fungos foi realizada por análise macroscópica das colônias, sendo contabilizadas as unidades formadoras de colônias (UFC).

Análise estatística: Para comparar a área de Caatinga salinizada com a área de Caatinga nativa (não salinizada) os dados foram submetidos à análise de variância e as médias comparadas pelo teste de Tukey $(\mathrm{P}<0,05)$, utilizando o programa Statistica. 


\section{RESULTADOS E DISCUSSÃO}

0 número de colônias de fungos filamentosos foi significativamente maior na área de Caatinga nativa (52) comparada a área salinizada (3), independente do período de coleta (Figura 1). Min et al. (2016) observaram que em solos com CE de 4.61e $8.04 \mathrm{dS} \mathrm{m}^{-1}$ há uma redução da comunidade de microorganismos presentes do solo, resultados que corroboram com os resultados no presente trabalho.

Mesmo sendo amplamente distribuídos, inclusive no semiárido (OLIVEIRA et al. 2013), os fungos filamentosos se mostraram sensíveis aos níveis de salinidade da área de estudo, onde a CE foi superior a $60 \mathrm{dS} / \mathrm{m}$. Segundo Richards (1954), o solo coletado da área de Caatinga salinizada é classificado como extremamente salino (CE > 16). A salinidade é um fator determinante da estrutura das comunidade de micro-organismos do solo (ANDRONOV et al. 2012).

Figura 1. Unidades formadoras de colônias (UFC) de fungos filamentosos em área de Caatinga salinizada e em área de Caatinga nativa, no projeto de irrigação Senador Nilo Coelho núcleo 11, Vale do Submédio São Francisco, Petrolina/ $\mathrm{PE}, \mathrm{Brasil}$, independentemente do período de coleta. Médias seguidas pela mesma letra, não diferem por Tukey a 5\%.

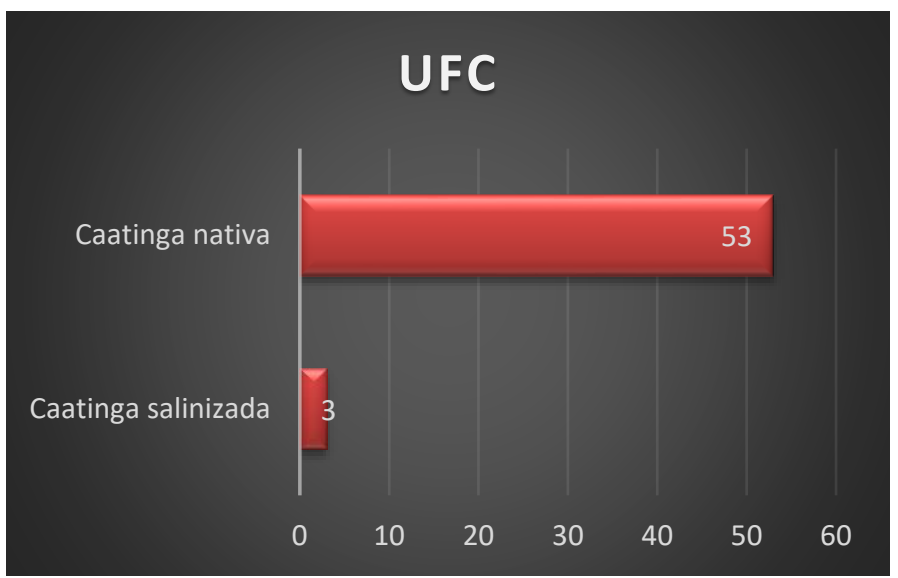

\section{CONCLUSÕES}

A salinização afeta negativamente as populações de fungos filamentosos, representado no presente trabalho pela quantidade de unidades formadoras de colônia.

\section{AGRADECIMENTOS}

À Coordenação de Aperfeiçoamento de Pessoal de Nível Superior (CAPES) pelo apoio ao Programa de PósGraduação em Ciência e Tecnologia Ambiental (PPGCTA), Universidade de Pernambuco, Brasil.

\section{REFERÊNCIAS}

[1]. ANDRONOV, E. E.; PETROVA, S. N.; PINAEV, A. G.; PERSHINA, E. V.; RAKHIMGALIEVA, S. Zh.; AKHMEDENOV, K. M.; GOROBETH, A. V.; SERGALIEV, N. Kh. Analysis of the Structure of Microbial Community in Soils with Different degrees of Salinization Using T-RFLP and Real-Time PCR Techniques,Eurasian Soil Science, v. 45 n. 2, p. 147-156, 2012.

[2]. CLARK, F.E. Agar-plate method for total microbial count. In Methods of soil analysis, Part 2. Chemicala nd microbiological properties. (C.A. Blanc, D. Evans, J.L. White, L.E. Ensminger, F.E. Clark \& R.C. Dinauer, eds.). Madson Inc., New York, p.1460-1466, 1965.

[3]. HALIRU, M.; KASIM, F. H.; GUNNY, A. A. N.; GOPINATH, S. C. B. Salt-adapted Moulds and Yeasts: Potentials in

Industrial and Environmental Biotechnology. Process Biochemistry. Disponível em:
https://doi.org/10.1016/j.procbio.2018.03.026 Acesso em: 20 de abril de 2018. 
[4]. MIN, W.; ; GUO, H.; ZHANG, W.; ZHOU, G.; MA, L.; YE, J.; LIANG, Y.; HOU, Z. Response of soil microbial community and diversity to increasing water salinity and nitrogen fertilization rate in an arid soil. Acta Agriculturae Scandinavica, Section B — Soil \& Plant Science. v. 66, n. 2, p. 117-126, 2016.

[5]. OLIVEIRA, L. G.; CAVALCANTI, M. A. Q.; FERNANDES, M. J. S.; LIMA, D. M. M. Diversity of filamentous fungi isolated from the soil in the semiarid area, Pernambuco, Brazil. Journal of Arid Environments, v. 95, p. 49-54, 2013.

[6]. RICHARDS, L. A. Diagnosis and improvement of saline and alkaline soils. Washington: United States Salinity Laboratory Staff, 1954.

[7]. WU, Y. P.; ZHANG, Y.; BI, Y. M.; SUN, Z. J. Biodiversity in saline and non-saline soils along the Bohai Sea coast, China. Pedosphere. 25(2): 307-315, 2015.

[8]. YAN, D.; YAN, D.; SONG, X.; YU, Z.; PENG, D.; TING, X.; WENG, B. Community structure of soil nematodes under different drought conditions. Geoderma, v. 325, p. 110 - 116, 2018. 


\section{Capítulo 18}

Síntese de carvão ativado fisicamente com vapor de água visando tratamento de efluentes industriais para fins de reúso

Ricardo Francisco Alves

José Luiz, Francisco Alves

Jean Constantino Gomes da Silva

Emmely Oliveira da Trindade

Guilherme Davi Mumbach

Rênnio Felix de Sena

Resumo: 0 Brasil e as demais regiões áridas e semiáridas do mundo sofrem limitações em seu desenvolvimento urbano nos setores agrícolas e industriais, ocasionadas pela escassez da água. 0 reúso de águas, além de auxiliar na preservação das águas de melhor qualidade para o consumo humano, é também uma forma de mitigação de contaminação de corpos receptores. Nesse contexto, o carvão ativado pode ser utilizado tanto no tratamento de águas de abastecimentos domésticos, quanto para tratamento de águas residuais da atividade industrial. Atualmente busca-se diminuir o custo de produção do carvão ativado, assim, o uso de fontes renováveis apresenta grande atrativo devido ao seu baixo custo. Assim, o objetivo do presente estudo foi a utilização de resíduos provenientes da poda de arborização urbana a fim de sintetizar carvão ativado fisicamente com vapor de água e caracterizar sua estrutura porosa através de análise de adsorção de N2 (g) a $77 \mathrm{~K}$ bem como o rendimento da produção do carvão ativado. Os resultados obtidos demonstraram que a utilização da poda da arborização urbana como precursor mostrou-se ser eficiente propiciou a síntese de um carvão com elevada capacidade adsortiva, elevada área BET e Langmuir, e satisfatórios valores de área e volume de microporos. Estes dados representam características promissoras para a utilização do precursor estudado para síntese de carvão ativado, assim, colaborando para sustentabilidade do meio ambiente. Além disso, o carvão ativado sintetizado contribuindo para redução da carga poluído em recursos hídricos no processo de tratamento de efluentes, bem como seu reuso.

Palavra-chave: carvão ativado, efluente industrial, reuso 


\section{INTRODUÇÃO}

O Brasil e as demais regiões áridas e semiáridas do mundo sofrem com limitações em seu desenvolvimento urbano, bem como em setores agrícolas e industriais. Essas limitações são ocasionadas devido as características geográficas e topográficas que chegam a causar a escassez de recursos naturais essenciais, como a água, para tal desenvolvimento. Águas com qualidade inferior, como esgotos domésticos, águas de drenagens agrícolas, águas salobras e águas residuárias industriais, devem ser consideradas fontes alternativas de captação para usos menos restritivos (KOROTTA-GAMAGE \& SATHASIVAN, 2017; WONG et al., 2018).

O reúso de águas, além de auxiliar na preservação das águas de melhor qualidade para o consumo humano é também uma barreira contra a contaminação dos corpos receptores e uma forma de redução de custos sendo que em várias regiões tem-se adotado a cobrança pela utilização deste recurso (WONG et al., 2018). Portanto, torna-se crescente a preocupação dos consumidores industriais em reduzir o volume de água utilizada. Neste contexto, o reúso de água no processo produtivo torna-se uma das metas a ser alcançada.

Existem vários processos de tratamento de águas residuárias, pode-se citar a filtração adsortiva, operações com membranas e processos oxidativos avançados. Em meio aos vários adsorventes existentes o carvão ativado ganha destaque. Segundo Danish (2018) carvão ativado é um material adsorvente largamente utilizado tanta no tratamento de águas de abastecimentos domésticos e industrial.

Tendo a perspectiva do desenvolvimento sustentável busca-se diminuir o custo de produção do carvão ativado, logo uma alternativa é a utilização de precursores de fontes renováveis e de baixo custo (IOANNIDOU \& ZABANIOTOU, 2007; DANISH \& AHMAD, 2018). Em decorrência dessa problemática o objetivo do presente estudo foi sintetizar carvão ativado fisicamente com vapor de água sintetizado a partir da poda da arborização urbana, ou seja, a partir de matérias-primas de baixo custo e buscando dar um destino sustentável e econômico para esses resíduos que muitas vezes são descartados de maneira inadequada. Além disso, caracterizar a estrutura porosa do carvão ativado através de análise de adsorção de $\mathrm{N}_{2}$ (g) a $77 \mathrm{~K}$ bem como o rendimento da produção do carvão ativado.

\section{METODOLOGIA}

\subsection{COLETA DO PRECURSOR E PRODUÇÃO DOS ADSORVENTES}

Inicialmente os resíduos da poda da arborização urbana, resíduos da Adenanthera pavonina (Figura 1), foram coletadas na região da grande João Pessoa, Estado da Paraíba. As amostras coletadas foram inicialmente submetidas a secagem por meio da exposição ao sol. Folhagens e galhos foram separados e cortados em tamanhos uniformes. 0 tamanho das amostras foi de aproximadamente $10 \mathrm{~cm}$. Após a homogeneização, as amostras foram mantidas em uma estufa com temperatura controlada de $80{ }^{\circ} \mathrm{C}$.

Figura 1 - Foto da poda da arborização urbana.

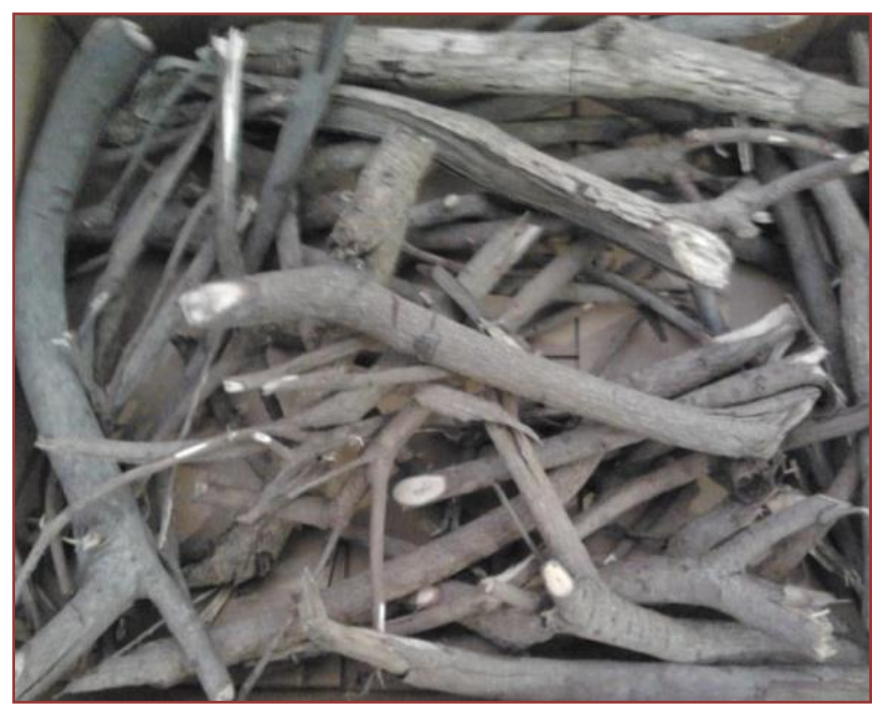


Para a ativação física, a amostra (galhos) devidamente homogeneizada foi submetida a uma temperatura de $1073 \mathrm{~K}\left(800^{\circ} \mathrm{C}\right)$ com atmosfera de vapor de água e $\mathrm{N}_{2}$ sob um fluxo constante de $15 \mathrm{~L} \mathrm{~h}^{-1}$ e $0,8 \mathrm{~kg} \mathrm{~h}^{-1}$, respectivamente. 0 nitrogênio é obtido a partir de uma câmara de armazenamento de nitrogênio líquido, isto conferia a ausência de agentes oxidantes atmosféricos e garantia a retirada de gases voláteis e semivoláteis eliminados durante a pirólise. 0 vapor de água utilizado para a produção do carvão ativado era produzido em uma caldeira elétrica acoplada ao forno, o qual era mistura na atmosfera de nitrogênio durante a síntese. A ativação física consistiu em pesar $100 \mathrm{~g}$ da poda da arborização urbana que estava na estufa e colocá-la no forno, ver Figura 2, onde o carvão ativado obtido foi denominado CAF. Ao término da ativação o forno foi desligado e o reator foi resfriado por transferência de calor por convecção forçada, até atingir a temperatura ambiente. Neste momento, o fluxo de nitrogênio é desligado e o carvão ativado produzido é colocado na estufa.

Figura 2 - Forno-reator tubular de leito fixo com rampa de aquecimento digital em atmosfera de $\mathrm{N}_{2}$ para pirólise da CHINO, adaptado à caldeira.

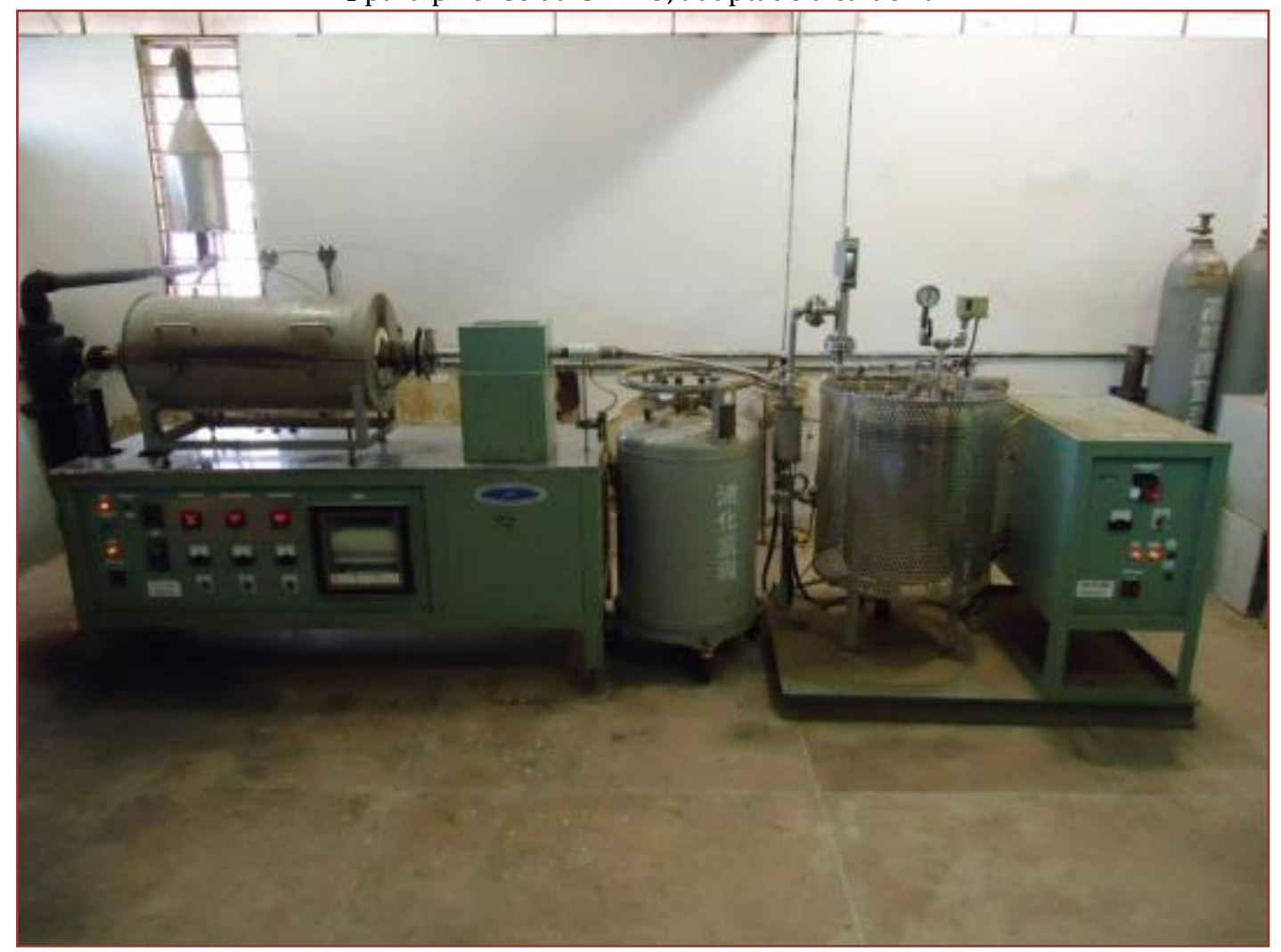

\subsection{CARACTERIZAÇÃO DO ADSORVENTE}

\subsubsection{RENDIMENTO}

Após a síntese, o carvão ativado foi levado à estufa a $110^{\circ} \mathrm{C}$ para secagem e, posteriormente, pesado a fim de determinar o rendimento. 0 rendimento foi calculado através da razão entre a massa final do carvão e a massa inicial em base seca (Eq. 1).

$$
\text { Rendimento }=100 \times\left(\frac{\mathrm{m}_{\text {final }}}{\mathrm{m}_{\text {inicial }}}\right)
$$




\subsubsection{PROPRIEDADES TEXTURAIS: ISOTERMAS DE ADSORÇÃO DE NITROGÊNIO}

Os carvões preparados foram caracterizados por adsorção/dessorção de $\mathrm{N}_{2}$ a $77 \mathrm{~K}$, utilizando o instrumento da MICROMERITICS, modelo ASAP 2020. A partir dos dados pode-se calcular a área superficial e volume de poros no carvão ativado.

\section{RESULTADOS E DISCUSSÃO}

A isoterma de adsorção de nitrogênio obtida para o carvão ativado proveniente dos resíduos de poda da arborização urbana (CAF), é apresentada na Figura 3. 0 perfil apresentado na isoterma de adsorção para CAF fornece informações preliminares sobre o mecanismo de adsorção e da estrutura porosa do carvão ativado.

Figura 3 - Isotermas de adsorção do carvão ativado CAF.

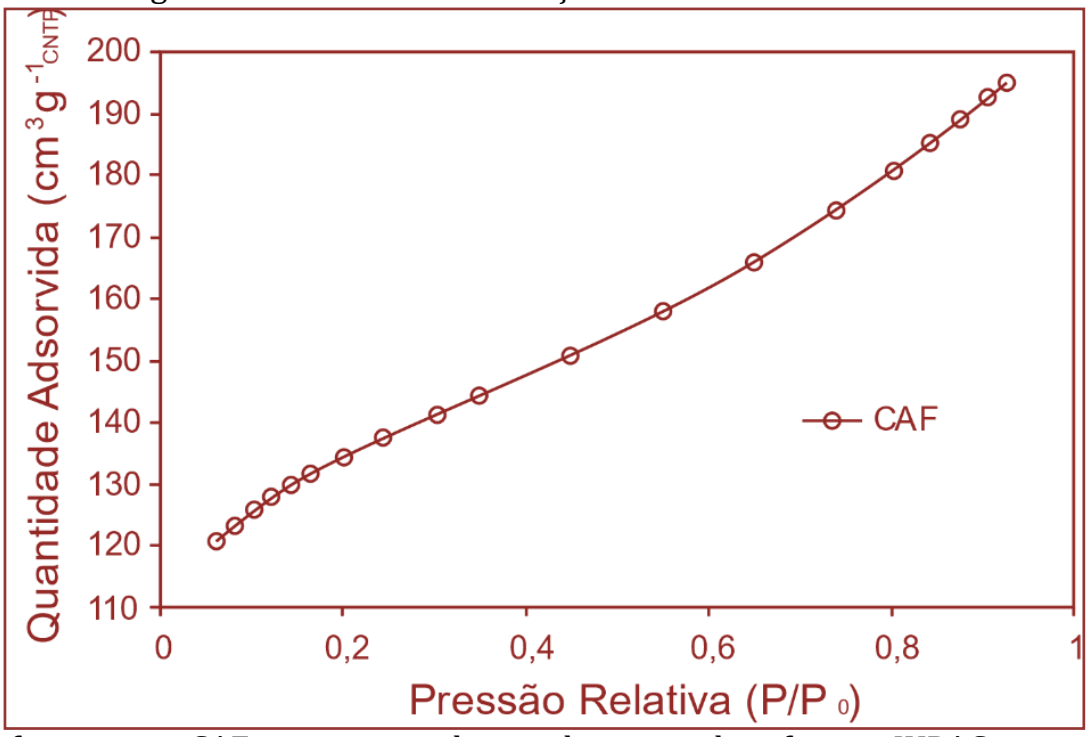

O carvão ativado fisicamente CAF apresentou, de acordo com a classificação IUPAC, uma isoterma do tipo II que é muito comum no caso de adsorção física, e corresponde à formação de multicamadas (THOMMES et al., 2015). 0 CAF apresentou uma capacidade de adsorção de gás $\mathrm{N}_{2}$ adsorvido (120 a $195 \mathrm{~cm}^{3} \mathrm{~g}^{-1} \mathrm{CNTP}$ ).

Figura 4 - Áreas superficiais e de microporo do CAF.

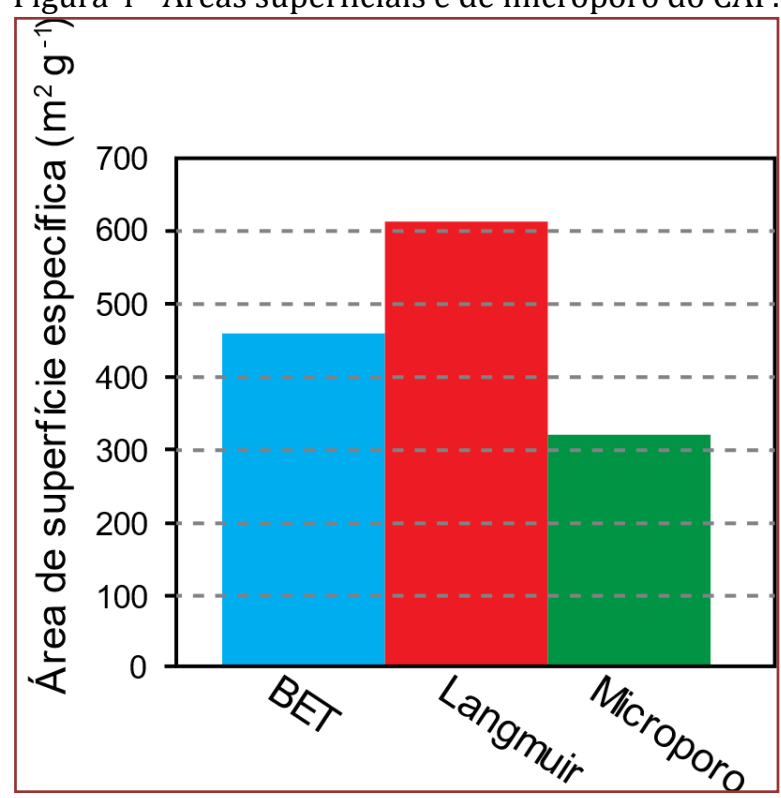


O carvão ativado fisicamente (CAF) possui área de superfície específica $\left(461 \mathrm{~m}^{2} \mathrm{~g}^{-1}\right.$ BET e $615 \mathrm{~m}^{2} \mathrm{~g}^{-1}$ Langmuir) e o seguinte resultado para o volume e área de microporos, $0,149 \mathrm{~cm}^{3} \mathrm{~g}-1$ e $322 \mathrm{~m}^{2} \mathrm{~g}^{-1}$, respectivamente, obtendo um rendimento de $19,4 \%$.

\section{CONCLUSÕES}

A produção de carvões ativados utilizando-se a poda urbana de árvore (especificamente a Adenanthera pavonina) mostrou-se ser eficiente propiciou a síntese de um carvão com elevada capacidade adsortiva, elevada área BET e Langmuir, e satisfatórios valores de área e volume de microporos.

Os resultados obtidos comprovam que a utilização do precursor estudado para síntese de carvão ativado se torna uma excelente alternativa de baixo custo capaz de colaborar para sustentabilidade do meio ambiente. Possuindo grande potencial de aplicabilidade desse carvão ativado sintetizado dentro do processo de tratamento de efluentes para fins de reúso por meio do processo de adsorção, contribuindo para diminuição da poluição hídrica.

\section{REFERÊNCIAS}

[1] DANISH, M.; AHMAD, T. A review on utilization of wood biomass as a sustainable precursor for activated carbon production and application. Renewable and Sustainable Energy Reviews, v. 87, p. 1-21, 2018. [s.n.]. http://dx.doi.org/10.1016/j.rser.2018.02.003.

[2] IOANNIDOU, O.; ZABANIOTOU, A. Agricultural residues as precursors for activated carbon production-A review. Renewable and Sustainable Energy Reviews, v. 11, n. 9, p. 1966-2005, 2007. [s.n.]. http://dx.doi.org/10.1016/j.rser.2006.03.013.

[3] KOROTTA-GAMAGE, S. M.; SATHASIVAN, A. A review: Potential and challenges of biologically activated carbon to remove natural organic matter in drinking water purification process. Chemosphere, v. 167, p. 120-138, 2017. [s.n.]. http://dx.doi.org/10.1016/j.chemosphere.2016.09.097.

[4] THOMMES, M.; KANEKO, K.; NEIMARK, A. V.; OLIVIER, J. P.; RODRIGUEZ-REINOSO, F.; ROUQUEROL, J.; SING, K. S. W. Physisorption of gases, with special reference to the evaluation of surface area and pore size distribution (IUPAC Technical Report). Pure and Applied Chemistry, v. 87, n. 9-10, 2015. [s.n.]. http://dx.doi.org/10.1515/pac2014-1117.

[5] WONG, S.; NGADI, N.; INUWA, I. M.; HASSAN, O. Recent advances in applications of activated carbon from biowaste for wastewater treatment: A short review. Journal of Cleaner Production, v. 175, p. 361-375, 2018. [s.n.]. http://dx.doi.org/10.1016/j.jclepro.2017.12.059. 


\section{Capítulo 19}

Development of tree species from Brazilian savanna consortiated with green manures in a revegetated area

\section{Eva de Melo Ferreira \\ Michel de Paula Andraus \\ Aline Assis Cardoso \\ Wilson Mozena Leandro}

Abstract : The use of native species in a degraded area is one of the main alternatives of revegetation and possible recovery of a local environment. Therefore, the use of legumes can provide the minimum necessary for the survival of the trees used, enriching the soil, and combating the invasion of exotic species. The study brings a proposal for a consortium between green manures and trees from the Brazilian Savanna as a form of regeneration in soils with deteriorated quality. The species used were: Dipteryx alata, Caryocar brasiliense, Guazuma ulmifolia, Byrsonima crassifolia, Physocalymma scaberrimum and Apeiba albiflora, intercropped with Cajanus cajan, Crotalaria juncea and Stilosante capitata 80\%. There was no consortium in two blocks. For one year the diameter and height of the plants were measured. Among one of the main results was the reduction in competition between cultivated and exotic species, e.g., Brachiaria. As a key to the success of similar projects, environmental monitoring throughout the development of vegetation is essential. Diversity in the choice of species is also recommended for pest control.

Keywords: green areas, soil enrichment, Environmental Monitoring, tree development. 


\section{INTRODUCTION}

The deforestation of green areas is a chronic problem in several countries, and the revegetation of these places can be expensive and requires regular monitoring. As one of the main soils uses in commodity exporting countries like Brazil, there are the agrobusiness and vegetable production. As access to water is facilitated, Permanent Preservation Areas (PPA) around water bodies are one of the affected ecosystems. According to the Brazilian Forest Code, PPAs are: "Protected areas covered or not by native vegetation, with the environmental function of preserving water resources, the landscape, geological stability, biodiversity, the genetic flow of fauna and flora, the soil and ensure the well-being of human populations".

In a decree of the year 2017, the Brazilian government committed itself to restore, by the year 2030, 12.5 million hectares of degraded areas. For example, the restoration of legal reserve areas represents about $4.5 \pm 1$ million hectares, with $0.6 \pm 0.35$ million hectares occupied by agricultural activities (Brasil, 2017). The use of native species in these restoration processes is important not only for the survival of plants, but also in increasing the resistance to pests in an ecologically sustainable way. The effects of revegetation on soil cover can be measured by assessing the physical and chemical attributes of the area. In a study carried out on degraded pasture area, in revegetation with leguminous species, it was possible using Acacia auriculiformis, Inga edulis and Mimosa caesalpiniifolia to partially recover the physical quality of the soil, since the tensile strength values were predominantly closer to the secondary forest than the degraded pasture under study (Faustino et al., 2021).

One of the initial stages of the revegetation process is to change the topsoil. This favours the development of plants and when it comes to agroecological production, it is essential in the removal of pesticides. In addition, topsoil can serve as resources for the selection of more resistant options and knowledge of colonizing species. In addition to legumes, grasses previously existing in the area are a good choice of plant species for degraded areas (Saraiva et al., 2020). After planting and establishing vegetation, control of the area is essential. Ferreira et al., (2018) agreeing that in PPAs, it is important to assess the original species, to increase the possibility of recovery and allow the resurgence of previously existing fauna.

The introduction of techniques that favour biological processes and provide greater productivity per unit area is important for ecological and economic sustainability (Labigaline et al., 2020). In terms of the above, some plants are useful in replacing the use of pesticides with agroecological alternatives. For this reason, the main objective of the present study was to evaluate the development of tree species in consortium with green manures in the restoration of degraded areas.

\section{MATERIAL AND METHODS}

The present work was carried out in a Permanent Preservation Area in process of revegetation. The process started in 2011, with the use of native species from the Brazilian Cerrado in a consortium with green manures. Among other benefits, green manures were used to reduce competition with the grass Urochloa, one of the most aggressive exotic species. Its development and spread are fast advancing. Another factor that explains the use of green manures is the maintenance of the trees. Pesticides were not used in pest control and soluble chemical fertilizers were not applied.

Downstream of the revegetated area there was the cultivation of organic coffee, a pivot used in the irrigation of experiments at the Agronomy School of Federal University of Goiás, and the planting of physic nut (Jatropha curcas). The trees used in the revegetation process were obtained from a commercial nursery in Goiânia. The planting and maintenance of the area was carried out by the University employees. One of the problems found at the site is the existence of large rodents, such as the capybara (Hydrochoerus hydrochaeris), which brought about the infestation by ticks.

The area where reforestation exists, was not in the entire PPA of the water body, but only on the right bank. The species were divided into nine blocks, with six trees in each, all the blocks with the same species. At the beginning of the work, all the first six blocks had green manure. Blocks seven, eight and nine were used in the study, as those without the presence of green manures. During the execution of the work, some plants died.

The diameter of the trees was measured using a calliper, in a position close to the ground. In all measurement months, this happened on the last day of the month and the measurement position of the plants was the same throughout the study. To measure the height, a simple measuring tape and topography sight of known length was used, the reference being the last leaf of the plant. The data were organized in electronic spreadsheets and analysed using free access statistical software. Statistical 
analyses were carried out in plots sub-subdivided over time. Green manures were the sub-plots, and the development period was sub-sub plots. The statistical analysis carried out considered the correlation between green manure and tree species, aiming at knowing possible interferences. In addition, graphs were constructed where dispersion curves were expressed to represent the development of the plants during the study period.

\section{RESULTS}

The species with the best development in relation to height was Apeiba albiflora- (AA). The green manure used in the area was Crotalaria juncea. The contribution of $\mathrm{N}$ to the soil / plant system is estimated between 100 and $300 \mathrm{~kg} \mathrm{~N} /$ ha / year (Silva et al., s/d). In the second block, the species with the best diameter development was the Guazuma ulmifolia. For the Dipteryx alata, there was no significant difference in height in all treatments (Table 1). In single cultivation, there was a difference between September and February (Table 2).

Table 1. Dipteryx alata height $(\mathrm{cm})$ in single cultivation and intercropped at different times of evaluation.

\begin{tabular}{|c|c|c|c|c|c|c|c|c|c|c|c|c|}
\hline \multirow{2}{*}{ Treatments } & \multicolumn{4}{|c|}{ First year } & \multicolumn{8}{|c|}{ Second year } \\
\hline & Sept & Oct. & Now. & Dec. & $\mathrm{Jan}$. & Feb. & Mar. & Apr. & May & Jun. & Jul. & Aug. \\
\hline $\begin{array}{l}\text { Dipteryx alata/Cajanus } \\
\text { cajan }\end{array}$ & $55,50 \mathrm{Aa}^{*}$ & $70,00 \mathrm{Aa}$ & $70,00 \mathrm{Aa}$ & $75,00 \mathrm{Aa}$ & $75,00 \mathrm{Aa}$ & $75,00 \mathrm{Aa}$ & $75,00 \mathrm{Aa}$ & $75,00 \mathrm{Aa}$ & $78,00 \mathrm{Aa}$ & $78,00 \mathrm{Aa}$ & $78,00 \mathrm{Aa}$ & $78,00 \mathrm{Aa}$ \\
\hline $\begin{array}{l}\text { Dipteryx alata/ } \\
\text { Estilosanthes capitata }\end{array}$ & $69,50 \mathrm{Aa}$ & $91,50 \mathrm{Aa}$ & $91,50 \mathrm{Aa}$ & $100,50 \mathrm{Aa}$ & $100,50 \mathrm{Aa}$ & $100,50 \mathrm{Aa}$ & $108,50 \mathrm{Aa}$ & $111,50 \mathrm{Aa}$ & $111,50 \mathrm{Aa}$ & $111,50 \mathrm{Aa}$ & $111,50 \mathrm{Aa}$ & $111,50 \mathrm{Aa}$ \\
\hline $\begin{array}{l}\text { Dipteryx } \\
\text { alata/Crotalaria juncea }\end{array}$ & $45,50 \mathrm{Aa}$ & $68,50 \mathrm{Aa}$ & $68,50 \mathrm{Aa}$ & $68,50 \mathrm{Aa}$ & $82,50 \mathrm{Aa}$ & $83,00 \mathrm{Aa}$ & $83,00 \mathrm{Aa}$ & $87,50 \mathrm{Aa}$ & $87,50 \mathrm{Aa}$ & $89,00 \mathrm{Aa}$ & $89,50 \mathrm{Aa}$ & $89,50 \mathrm{Aa}$ \\
\hline Dipteryx alata & $29,50 \mathrm{Aa}$ & $42,50 \mathrm{Aa}$ & $42,50 \mathrm{Aa}$ & $58,50 \mathrm{Aa}$ & $58,50 \mathrm{Aa}$ & $69,00 \mathrm{Aa}$ & $69,00 \mathrm{Aa}$ & $87,00 \mathrm{Aa}$ & $88,50 \mathrm{Aa}$ & $88,50 \mathrm{Aa}$ & $90,00 \mathrm{Aa}$ & $90,00 \mathrm{Aa}$ \\
\hline
\end{tabular}

* Values followed by the same letter, uppercase in the column and lowercase in the row, do not differ by Tukey's test at $5 \%$ probability.

Table 2. Dipteryx alata diameter (mm), in single cultivation and intercropped at different times of evaluation.

\begin{tabular}{|c|c|c|c|c|c|c|c|c|c|c|c|c|}
\hline \multirow{2}{*}{ Treatments } & \multicolumn{4}{|c|}{ First year } & \multicolumn{8}{|c|}{ Second year } \\
\hline & Sept. & Oct. & Nov. & Dec. & Jan. & Feb. & Mar. & Apr. & May & Jun. & Jul. & Aug. \\
\hline $\begin{array}{l}\text { Dipteryx alata/Cajanus } \\
\text { cajan }\end{array}$ & $11,00 \mathrm{Aa}^{*}$ & $11,30 \mathrm{Aa}$ & $11,30 \mathrm{Aa}$ & $11,30 \mathrm{Aa}$ & $15,04 \mathrm{Aa}$ & $15,42 \mathrm{Aa}$ & $16,71 \mathrm{Aa}$ & $16,74 \mathrm{Aa}$ & $17,56 \mathrm{Aa}$ & $17,66 \mathrm{Aa}$ & $19,87 \mathrm{Aa}$ & $27,11 \mathrm{Aa}$ \\
\hline $\begin{array}{l}\text { Dipteryx alata/ } \\
\text { Estilosanthes capitata }\end{array}$ & $10,98 \mathrm{Aa}$ & $13,08 \mathrm{Aa}$ & $13,08 \mathrm{Aa}$ & $13,85 \mathrm{Aa}$ & $14,73 \mathrm{Aa}$ & $15,18 \mathrm{Aa}$ & $17,48 \mathrm{Aa}$ & $17,62 \mathrm{Aa}$ & $17,62 \mathrm{Aa}$ & $18,48 \mathrm{Aa}$ & $18,94 \mathrm{Aa}$ & $18,94 \mathrm{Aa}$ \\
\hline $\begin{array}{l}\text { Dipteryx } \\
\text { alata/Crotalaria juncea }\end{array}$ & $9,07 \mathrm{Aa}$ & $14,49 \mathrm{Aa}$ & $14,49 \mathrm{Aa}$ & $14,49 \mathrm{Aa}$ & $15,31 \mathrm{Aa}$ & $15,85 \mathrm{Aa}$ & $15,85 \mathrm{Aa}$ & $15,55 \mathrm{Aa}$ & $17,35 \mathrm{Aa}$ & $17,95 \mathrm{Aa}$ & $17,95 \mathrm{Aa}$ & $18,41 \mathrm{Aa}$ \\
\hline Dipteryx alata & $5,77 \mathrm{Ab}$ & 7,39 Aab & 7,39 Aab & $7,60 \mathrm{Aab}$ & $10,95 \mathrm{Aab}$ & $11,60 \mathrm{Aab}$ & $19,00 \mathrm{Aa}$ & $19,00 \mathrm{Aa}$ & $19,00 \mathrm{Aa}$ & $19,50 \mathrm{Aa}$ & $19,50 \mathrm{Aa}$ & $19,50 \mathrm{Aa}$ \\
\hline
\end{tabular}

* Values followed by the same letter, uppercase in the column and lowercase in the row, do not differ by Tukey's test at $5 \%$ probability.

Table 3. Caryocar Brasiliense height (cm) in single cultivation and intercropped at different times of evaluation.

\begin{tabular}{|c|c|c|c|c|c|c|c|c|c|c|c|c|}
\hline \multirow{2}{*}{ Tratamentos } & \multicolumn{4}{|c|}{ First year } & \multicolumn{8}{|c|}{ Second year } \\
\hline & Sept. & Oct. & Nov. & Dec. & Jan. & Feb. & Mar. & Apr. & May & Jun. & Jul. & Ago. \\
\hline $\begin{array}{l}\text { Caryocar brasiliense/ } \\
\text { Cajanus cajan }\end{array}$ & $69,00 \mathrm{Ab}^{*}$ & $79,50 \mathrm{Ab}$ & $79,50 \mathrm{Ab}$ & $107,50 \mathrm{Aab}$ & $109,00 \mathrm{Aa}$ & $202,00 \mathrm{Aa}$ & $213,00 \mathrm{Aa}$ & $155,50 \mathrm{Aab}$ & $162,50 \mathrm{Aab}$ & $167,50 \mathrm{Aab}$ & $171,00 \mathrm{Aab}$ & $171,00 \mathrm{Aab}$ \\
\hline $\begin{array}{l}\text { Caryocar brasiliense/ } \\
\text { Estilosanthes capitata }\end{array}$ & $63,00 \mathrm{Aa}$ & $64,00 \mathrm{Aa}$ & $64,00 \mathrm{Aa}$ & $95,00 \mathrm{Aa}$ & $105,00 \mathrm{Ba}$ & $130,00 \mathrm{ABa}$ & $105,00 \mathrm{Ba}$ & $105,00 \mathrm{ABa}$ & $105,00 \mathrm{ABa}$ & $109,00 \mathrm{ABa}$ & $109,00 \mathrm{ABa}$ & $109,00 \mathrm{ABa}$ \\
\hline $\begin{array}{l}\text { Caryocar brasiliense/ } \\
\text { Crotalaria juncea }\end{array}$ & $92,50 \mathrm{Aa}$ & $92,50 \mathrm{Aa}$ & $92,50 \mathrm{Aa}$ & $92,00 \mathrm{Aa}$ & $126,00 \mathrm{ABa}$ & $128,00 \mathrm{ABa}$ & $116,00 \mathrm{Ba}$ & $123,00 \mathrm{Aa}$ & $125,00 \mathrm{Aba}$ & $122,50 \mathrm{ABa}$ & $130,00 \mathrm{Aa}$ & $130,00 \mathrm{Aa}$ \\
\hline Caryocar brasiliense & $140,50 \mathrm{Aa}$ & $140,50 \mathrm{Aa}$ & $140,50 \mathrm{Aa}$ & $140,50 \mathrm{Aa}$ & $140,00 \mathrm{ABa}$ & $104,00 \mathrm{Ba}$ & $31,50 \mathrm{Ba}$ & $32,00 \mathrm{Ba}$ & $39,00 \mathrm{Ba}$ & $39,00 \mathrm{Ba}$ & $39,00 \mathrm{Ba}$ & $39,00 \mathrm{Ba}$ \\
\hline
\end{tabular}

* Values followed by the same letter, uppercase in the column and lowercase in the row, do not differ by Tukey's test at $5 \%$ probability. 
Table 4. Caryocar brasiliense diameter ( $\mathrm{mm}$ ) in single and intercropped cultivation at different times of evaluation.

\begin{tabular}{|c|c|c|c|c|c|c|c|c|c|c|c|c|}
\hline \multirow{2}{*}{ Treatments } & \multicolumn{4}{|c|}{ First year } & \multicolumn{8}{|c|}{ Second year } \\
\hline & Sept. & Oct. & Nov. & Dec. & Jan. & Feb. & Mar. & Apr. & May & Jun. & Jul. & Aug. \\
\hline $\begin{array}{l}\text { Caryocar brasiliense/ } \\
\text { Cajanus cajan }\end{array}$ & $12,83 \mathrm{Aa}^{*}$ & 13,30 Aba & $15,67 \mathrm{Aa}$ & $16,10 \mathrm{Aa}$ & $19,93 \mathrm{Aa}$ & $22,47 \mathrm{Aa}$ & $22,64 \mathrm{Aa}$ & $23,73 \mathrm{Aa}$ & $23,73 \mathrm{Aa}$ & $23,92 \mathrm{Aa}$ & $24,12 \mathrm{Aa}$ & $24,26 \mathrm{ABa}$ \\
\hline $\begin{array}{l}\text { Caryocar brasiliense/ } \\
\text { Estilosanthes capitata }\end{array}$ & $12,00 \mathrm{Aa}$ & $13,73 \mathrm{ABa}$ & $13,73 \mathrm{Aa}$ & $13,73 \mathrm{Aa}$ & $16,82 \mathrm{Aa}$ & $16,82 \mathrm{ABa}$ & $17,00 \mathrm{Aa}$ & $17,00 \mathrm{ABa}$ & $17,03 \mathrm{ABa}$ & $18,80 \mathrm{ABa}$ & $21,40 \mathrm{Aba}$ & $21,98 \mathrm{ABa}$ \\
\hline $\begin{array}{l}\text { Caryocar brasiliense/ } \\
\text { Crotalaria juncea }\end{array}$ & $13,98 \mathrm{Aa}$ & $16,02 \mathrm{Aa}$ & $16,02 \mathrm{Aa}$ & 19,35 Aa & $19,70 \mathrm{Aa}$ & $19,70 \mathrm{Aa}$ & $19,83 \mathrm{Aa}$ & $22,02 \mathrm{Aa}$ & $23,91 \mathrm{Aa}$ & $25,78 \mathrm{Aa}$ & $28,14 \mathrm{Aa}$ & $31,45 \mathrm{Aa}$ \\
\hline Caryocar brasiliense & $5,03 \mathrm{Ba}$ & $5,03 \mathrm{Ba}$ & $5,03 \mathrm{Ba}$ & $5,03 \mathrm{Ba}$ & $5,33 \mathrm{Ba}$ & $5,35 \mathrm{Ba}$ & 6,83 Ba & $6,83 \mathrm{Ba}$ & $7,59 \mathrm{Ba}$ & $7,59 \mathrm{Ba}$ & $7,59 \mathrm{Ba}$ & $7,59 \mathrm{Ba}$ \\
\hline
\end{tabular}

* Values followed by the same letter, uppercase in the column and lowercase in the row, do not differ by Tukey's test at $5 \%$ probability.

Table 5. Guazuma ulmifolia height $(\mathrm{cm})$ in single cultivation and intercropped at different times of evaluation.

\begin{tabular}{|c|c|c|c|c|c|c|c|c|c|c|c|c|}
\hline \multirow{2}{*}{ Treatments } & \multicolumn{4}{|c|}{ First year } & \multicolumn{8}{|c|}{ Second year } \\
\hline & Sept. & Oct. & Nov. & Dec. & Jan. & Feb. & Mar. & Apr. & May & Jun. & Jul. & Aug. \\
\hline $\begin{array}{l}\text { Guazuma ulmifolia/ } \\
\text { Cajanus cajan }\end{array}$ & $228,00 \mathrm{Aa}^{*}$ & $275,00 \mathrm{Aa}$ & $275,00 \mathrm{Aa}$ & $292,50 \mathrm{Aa}$ & $301,50 \mathrm{Aa}$ & $312,00 \mathrm{Aa}$ & $335,00 \mathrm{Aa}$ & $328,00 \mathrm{Aa}$ & $355,00 \mathrm{Aa}$ & $360,00 \mathrm{Aa}$ & $367,50 \mathrm{Aa}$ & $367,50 \mathrm{Aa}$ \\
\hline $\begin{array}{l}\text { Guazuma ulmifolia/ } \\
\text { Estilosanthes capitata }\end{array}$ & $96,50 \mathrm{Aa}$ & $178,50 \mathrm{Aa}$ & $178,50 \mathrm{Aa}$ & $146,00 \mathrm{Aa}$ & $290,00 \mathrm{Aa}$ & $330,00 \mathrm{Aa}$ & $217,50 \mathrm{Aa}$ & $221,50 \mathrm{Aa}$ & $230,00 \mathrm{Aa}$ & $207,50 \mathrm{Aa}$ & $355,00 \mathrm{Aa}$ & $230,50 \mathrm{Aa}$ \\
\hline $\begin{array}{l}\text { Guazuma ulmifolia/ } \\
\text { Crotalaria juncea }\end{array}$ & $205,00 \mathrm{Aa}$ & $230,00 \mathrm{Aa}$ & $230,00 \mathrm{Aa}$ & $190,00 \mathrm{Aa}$ & $198,50 \mathrm{Aa}$ & $202,50 \mathrm{Aa}$ & $294,00 \mathrm{Aa}$ & $294,00 \mathrm{Aa}$ & $315,00 \mathrm{Aa}$ & $305,00 \mathrm{Aa}$ & $325,00 \mathrm{Aa}$ & $335,00 \mathrm{Aa}$ \\
\hline Guazuma ulmifolia & $225,00 \mathrm{Aa}$ & $238,00 \mathrm{Aa}$ & $240,50 \mathrm{Aa}$ & $252,50 \mathrm{Aa}$ & $277,00 \mathrm{Aa}$ & $281,00 \mathrm{Aa}$ & $343,50 \mathrm{Aa}$ & $372,00 \mathrm{Aa}$ & $396,00 \mathrm{Aa}$ & $385,00 \mathrm{Aa}$ & $405,00 \mathrm{Aa}$ & $420,00 \mathrm{Aa}$ \\
\hline
\end{tabular}

* Values followed by the same letter, uppercase in the column and lowercase in the row, do not differ by Tukey's test at $5 \%$ probability.

Table 6. Guazuma ulmifolia diameter ( $\mathrm{mm}$ ) in single cultivation and intercropped at different times of evaluation.

\begin{tabular}{|c|c|c|c|c|c|c|c|c|c|c|c|c|}
\hline \multirow{2}{*}{ Treatments } & \multicolumn{4}{|c|}{ First year } & \multicolumn{8}{|c|}{ Second year } \\
\hline & Sept. & Oct. & Nov. & Dec. & Jan. & Feb. & Mar. & Apr. & May & Jun. & Jul. & Aug. \\
\hline $\begin{array}{l}\text { Guazuma ulmifolia/ } \\
\text { Cajanus cajan }\end{array}$ & $61,16 \mathrm{Aa}^{*}$ & $61,54 \mathrm{Aa}$ & $61,54 \mathrm{Aa}$ & $63,49 \mathrm{Aa}$ & $80,47 \mathrm{Aa}$ & $81,82 \mathrm{Aa}$ & $76,75 \mathrm{Aa}$ & $81,50 \mathrm{Aa}$ & $82,50 \mathrm{Aa}$ & $82,50 \mathrm{Aa}$ & $82,50 \mathrm{Aa}$ & $82,50 \mathrm{Aa}$ \\
\hline $\begin{array}{l}\text { Guazuma ulmifolia/ } \\
\text { Estilosanthes capitata }\end{array}$ & $14,45 \mathrm{Aa}$ & $45,49 \mathrm{Aa}$ & $45,49 \mathrm{Aa}$ & $45,49 \mathrm{Aa}$ & $91,58 \mathrm{Aa}$ & $93,10 \mathrm{Aa}$ & $50,52 \mathrm{Aa}$ & $50,52 \mathrm{Aa}$ & $48,80 \mathrm{Aa}$ & $50,28 \mathrm{Aa}$ & $93,10 \mathrm{Aa}$ & $50,43 \mathrm{Aa}$ \\
\hline $\begin{array}{l}\text { Guazuma ulmifolia/ } \\
\text { Crotalaria juncea }\end{array}$ & $52,86 \mathrm{Aa}$ & $54,84 \mathrm{Aa}$ & $54,84 \mathrm{Aa}$ & $77,19 \mathrm{Aa}$ & $44,25 \mathrm{Aa}$ & $45,06 \mathrm{Aa}$ & $63,44 \mathrm{Aa}$ & $75,87 \mathrm{Aa}$ & $69,91 \mathrm{Aa}$ & $75,82 \mathrm{Aa}$ & $76,04 \mathrm{Aa}$ & $81,73 \mathrm{Aa}$ \\
\hline Guazuma ulmifolia & $63,47 \mathrm{Aa}$ & $61,95 \mathrm{Aa}$ & $63,45 \mathrm{Aa}$ & $56,45 \mathrm{Aa}$ & $60,35 \mathrm{Aa}$ & $64,49 \mathrm{Aa}$ & $86,20 \mathrm{Aa}$ & $93,98 \mathrm{Aa}$ & $91,10 \mathrm{Aa}$ & $96,46 \mathrm{Aa}$ & $99,46 \mathrm{Aa}$ & $99,90 \mathrm{Aa}$ \\
\hline
\end{tabular}

* Values followed by the same letter, uppercase in the column and lowercase in the row, do not differ by Tukey's test at $5 \%$ probability.

Table 7. Byrsonima crassifólia height (cm) in single cultivation and intercropped at different times of evaluation.

\begin{tabular}{|c|c|c|c|c|c|c|c|c|c|c|c|c|}
\hline \multirow{2}{*}{ Treatments } & \multicolumn{4}{|c|}{ First year } & \multicolumn{8}{|c|}{ Second year } \\
\hline & Sept. & Oct. & Nov. & Dec. & Jan. & Feb. & Mar. & Apr. & May & Jun. & Jul. & Aug. \\
\hline $\begin{array}{l}\text { Byrsonima crassifólia/ } \\
\text { Cajanus cajan }\end{array}$ & $114,50 \mathrm{Aa}^{*}$ & $97,00 \mathrm{Aa}$ & $97,00 \mathrm{Aa}$ & $121,75 \mathrm{Aa}$ & $121,50 \mathrm{Aa}$ & $135,50 \mathrm{Aa}$ & $136,50 \mathrm{Aa}$ & $141,00 \mathrm{Aa}$ & $141,00 \mathrm{Aa}$ & $145,00 \mathrm{Aa}$ & $150,50 \mathrm{Aa}$ & $156,50 \mathrm{Aa}$ \\
\hline $\begin{array}{l}\text { Byrsonima crassifólia/ } \\
\text { Estilosanthes capitata }\end{array}$ & $97,50 \mathrm{Aa}$ & $94,00 \mathrm{Aa}$ & $94,00 \mathrm{Aa}$ & $100,50 \mathrm{Aa}$ & $108,00 \mathrm{Aa}$ & $105,00 \mathrm{Aa}$ & $93,50 \mathrm{Aa}$ & $93,50 \mathrm{Aa}$ & $102,50 \mathrm{Aa}$ & $101,00 \mathrm{Aa}$ & $120,00 \mathrm{Aa}$ & $100,00 \mathrm{Aa}$ \\
\hline $\begin{array}{l}\text { Byrsonima crassifólia/ } \\
\text { Crotalaria juncea }\end{array}$ & $126,00 \mathrm{Aa}$ & $95,00 \mathrm{Aa}$ & $95,00 \mathrm{Aa}$ & $175,50 \mathrm{Aa}$ & $187,50 \mathrm{Aa}$ & $193,50 \mathrm{Aa}$ & $107,50 \mathrm{Aa}$ & $111,00 \mathrm{Aa}$ & $111,00 \mathrm{Aa}$ & $110,00 \mathrm{Aa}$ & $112,00 \mathrm{Aa}$ & $112,00 \mathrm{Aa}$ \\
\hline Byrsonima crassifólia & $67,50 \mathrm{Aa}$ & $107,50 \mathrm{Aa}$ & $107,50 \mathrm{Aa}$ & $126,00 \mathrm{Aa}$ & $147,00 \mathrm{Aa}$ & $108,00 \mathrm{Aa}$ & $146,50 \mathrm{Aa}$ & $155,50 \mathrm{Aa}$ & $155,50 \mathrm{Aa}$ & $161,00 \mathrm{Aa}$ & $162,50 \mathrm{Aa}$ & $165,00 \mathrm{Aa}$ \\
\hline
\end{tabular}

* Values followed by the same letter, uppercase in the column and lowercase in the row, do not differ by Tukey's test at $5 \%$ probability. 
Table 8. Byrsonima crassifólia diameter $(\mathrm{mm})$ in single cultivation and intercropped at different times of evaluation.

\begin{tabular}{|c|c|c|c|c|c|c|c|c|c|c|c|c|}
\hline \multirow{2}{*}{ Treatments } & \multicolumn{4}{|c|}{ First year } & \multicolumn{8}{|c|}{ Second year } \\
\hline & Sept. & Oct. & Nov. & Dec. & Jan. & Feb. & Mar. & Apr. & May & Jun. & Jul. & Aug. \\
\hline $\begin{array}{l}\text { Byrsonima crassifólia/ } \\
\text { Cajanus cajan }\end{array}$ & $18,56 \mathrm{Aa}^{*}$ & $20,41 \mathrm{Aa}$ & $20,41 \mathrm{Aa}$ & $19,80 \mathrm{BAa}$ & $22,46 \mathrm{BAa}$ & $24,18 \mathrm{BAa}$ & 23,21 Aa & $22,05 \mathrm{Aa}$ & $24,12 \mathrm{Aa}$ & $24,12 \mathrm{Aa}$ & $24,12 \mathrm{Aa}$ & $24,50 \mathrm{Aa}$ \\
\hline $\begin{array}{l}\text { Byrsonima crassifólia/ } \\
\text { Estilosanthes capitata }\end{array}$ & $9,90 \mathrm{Aa}$ & $12,24 \mathrm{Aa}$ & $12,24 \mathrm{Aa}$ & $12,24 \mathrm{Ba}$ & 13,03 Ba & $14,71 \mathrm{Ba}$ & $9,26 \mathrm{Aa}$ & 11,18 Aa & $9,87 \mathrm{Aa}$ & $11,36 \mathrm{Aa}$ & $15,25 \mathrm{Aa}$ & $10,71 \mathrm{Aa}$ \\
\hline $\begin{array}{l}\text { Byrsonima crassifólia/ } \\
\text { Crotalaria juncea }\end{array}$ & $16,40 \mathrm{Aa}$ & $15,06 \mathrm{Aa}$ & $15,06 \mathrm{Aa}$ & $36,82 \mathrm{Aa}$ & $41,17 \mathrm{Aa}$ & $41,78 \mathrm{Aa}$ & $14,85 \mathrm{Aa}$ & $16,44 \mathrm{Aa}$ & $16,44 \mathrm{Aa}$ & $16,44 \mathrm{Aa}$ & $17,97 \mathrm{Aa}$ & $17,97 \mathrm{Aa}$ \\
\hline Byrsonima crassifólia & $31,45 \mathrm{Aa}$ & $18,09 \mathrm{Aa}$ & $18,09 \mathrm{Aa}$ & $18,00 \mathrm{BAa}$ & $20,67 \mathrm{BAa}$ & $16,11 \mathrm{Ba}$ & $25,44 \mathrm{Aa}$ & $25,66 \mathrm{Aa}$ & $27,86 \mathrm{Aa}$ & $28,18 \mathrm{Aa}$ & $29,77 \mathrm{Aa}$ & $32,34 \mathrm{Aa}$ \\
\hline
\end{tabular}

* Values followed by the same letter, uppercase in the column and lowercase in the row, do not differ by Tukey's test at $5 \%$ probability.

Table 9. Physocalymma scaberrimum height $(\mathrm{cm})$ in single cultivation and intercropped at different times of evaluation.

\begin{tabular}{|c|c|c|c|c|c|c|c|c|c|c|c|c|}
\hline \multirow{2}{*}{ Treatments } & \multicolumn{4}{|c|}{ First year } & \multicolumn{8}{|c|}{ Second year } \\
\hline & Sept. & Oct. & Nov. & Dec. & Jan. & Feb. & Mar. & Apr. & May & Jun. & Jul. & Aug. \\
\hline $\begin{array}{l}\text { Physocalymma } \\
\text { scaberrimum/Cajanus } \\
\text { cajan }\end{array}$ & $88,00 \mathrm{Aa}^{*}$ & $97,00 \mathrm{Aa}$ & $97,00 \mathrm{Aa}$ & $105,50 \mathrm{Aa}$ & $173,50 \mathrm{Aa}$ & $179,50 \mathrm{Aa}$ & $179,50 \mathrm{Aa}$ & $179,50 \mathrm{Aa}$ & $179,50 \mathrm{Aa}$ & $180,50 \mathrm{Aa}$ & $180,50 \mathrm{Ba}$ & $180,50 \mathrm{Aa}$ \\
\hline $\begin{array}{l}\text { Physocalymma } \\
\text { scaberrimum/ } \\
\text { Estilosanthes capitata }\end{array}$ & $112,50 \mathrm{Aa}$ & $100,00 \mathrm{Aa}$ & $100,00 \mathrm{Aa}$ & $177,50 \mathrm{Aa}$ & $165,00 \mathrm{Aa}$ & $123,00 \mathrm{Aa}$ & $122,50 \mathrm{Aa}$ & $133,50 \mathrm{Aa}$ & $137,50 \mathrm{Aa}$ & $141,50 \mathrm{Aa}$ & $150,00 \mathrm{Ba}$ & $160,00 \mathrm{Aa}$ \\
\hline $\begin{array}{l}\text { Physocalymma } \\
\text { scaberrimum/ } \\
\text { Crotalaria juncea }\end{array}$ & $107,50 \mathrm{Aa}$ & $134,00 \mathrm{Aa}$ & $134,00 \mathrm{Aa}$ & $140,50 \mathrm{Aa}$ & $141,50 \mathrm{Aa}$ & $146,50 \mathrm{Aa}$ & $195,00 \mathrm{Aa}$ & $200,50 \mathrm{Aa}$ & $215,00 \mathrm{Aa}$ & $221,50 \mathrm{Aa}$ & $227,50 \mathrm{ABa}$ & $241,00 \mathrm{Aa}$ \\
\hline $\begin{array}{l}\text { Physocalymma } \\
\text { scaberrimum }\end{array}$ & $62,00 \mathrm{Ab}$ & $72,00 \mathrm{Ab}$ & $72,00 \mathrm{Ab}$ & $129,50 \mathrm{Aab}$ & $157,50 \mathrm{Aab}$ & $148,00 \mathrm{Aab}$ & $71,00 \mathrm{Ab}$ & $236,00 \mathrm{Aa}$ & $242,50 \mathrm{Aa}$ & $239,50 \mathrm{Aa}$ & $300,00 \mathrm{Aa}$ & $330,00 \mathrm{Aa}$ \\
\hline
\end{tabular}

* Values followed by the same letter, uppercase in the column and lowercase in the row, do not differ by Tukey's test at $5 \%$ probability.

Table 10. Physocalymma scaberrimum diameter ( $\mathrm{mm}$ ) in single and intercropped cultivation at different times of evaluation.

\begin{tabular}{|c|c|c|c|c|c|c|c|c|c|c|c|c|}
\hline \multirow{2}{*}{ Treatments } & \multicolumn{4}{|c|}{ First year } & \multicolumn{8}{|c|}{ Second year } \\
\hline & Sept. & Oct. & Nov. & Dec. & Jan. & Feb. & Mar. & Apr. & May & Jun. & Jul. & Aug. \\
\hline $\begin{array}{l}\text { Physocalymma } \\
\text { scaberrimum/Cajanus } \\
\text { cajan }\end{array}$ & $17,50 \mathrm{Aa}^{*}$ & $15,99 \mathrm{Aa}$ & $15,99 \mathrm{Aa}$ & $17,50 \mathrm{Aa}$ & $21,42 \mathrm{Aa}$ & $21,42 \mathrm{Aa}$ & $21,61 \mathrm{Aa}$ & 23,05 Aa & $24,18 \mathrm{Aa}$ & $26,15 \mathrm{Aa}$ & $28,60 \mathrm{Ba}$ & $28,90 \mathrm{Ba}$ \\
\hline $\begin{array}{l}\text { Physocalymma } \\
\text { scaberrimum/ } \\
\text { Estilosanthes capitata }\end{array}$ & $47,25 \mathrm{Aa}$ & $17,78 \mathrm{Aa}$ & $17,78 \mathrm{Aa}$ & $44,25 \mathrm{Aa}$ & $43,15 \mathrm{Aa}$ & $25,65 \mathrm{Aa}$ & $27,90 \mathrm{Aa}$ & 32,19 Aa & $33,62 \mathrm{Aa}$ & $33,62 \mathrm{Aa}$ & $33,62 \mathrm{Ba}$ & $35,20 \mathrm{Ba}$ \\
\hline $\begin{array}{l}\text { Physocalymma } \\
\text { scaberrimum/ } \\
\text { Crotalaria juncea }\end{array}$ & $18,79 \mathrm{Aa}$ & $56,85 \mathrm{Aa}$ & $56,85 \mathrm{Aa}$ & $55,03 \mathrm{Aa}$ & $18,75 \mathrm{Aa}$ & 19,56 Aa & 31,34 Aa & $34,66 \mathrm{Aa}$ & 33,01 Aa & $37,41 \mathrm{Aa}$ & $37,85 \mathrm{Ba}$ & $39,39 \mathrm{Ba}$ \\
\hline $\begin{array}{l}\text { Physocalymma } \\
\text { scaberrimum }\end{array}$ & $7,75 \mathrm{Ab}$ & $8,35 \mathrm{Ab}$ & $8,35 \mathrm{Ab}$ & $16,00 \mathrm{Ab}$ & $23,80 \mathrm{Ab}$ & $23,94 \mathrm{Ab}$ & $26,70 \mathrm{Ab}$ & $61,06 \mathrm{Aab}$ & 65,73 Aab & 65,38 Aab & $124,50 \mathrm{Aa}$ & $124,50 \mathrm{Aa}$ \\
\hline
\end{tabular}

* Values followed by the same letter, uppercase in the column and lowercase in the row, do not differ by Tukey's test at $5 \%$ probability.

\section{DISCUSSION}

Cerrado, the Brazilian Savannah, is characterized by acid soils that exhibit low natural fertility and highwater deficit throughout the dry season, which occurs between May and September. Therefore, native plants have evolved to develop mechanisms of adaptation to water deficit conditions (Miranda et al., 2019). Caryocar brasiliense is a specie with slow development and a tree protected under federal law in Brazil. These trees remain isolated in deforested areas, with increasing vulnerability in which Tetranychus sp., Eutetranychus sp. (Tetranychidae), and Histiostoma sp. (Histiostomidae) are predators of the leaves and fruits (Leite et al., 2020). Hence, these trees are left in the Cerrado areas even after being converted to pasture, urban or agricultural areas, with a common scenario of isolated plants in the agro-urban landscape (Demolin-Leite et al., 2020).

In the present study, the plant showed a significant difference in the first treatment related to height, from September to December and after April to August again. In the second treatment from January to August, 
in the third in the months of January, February, March, May and June and when evaluating the single plant, it was observed in the months of January, February, March, April, May, June and August. One reason for this can be the influence of rain volume in the plant development. As shown in Table 4, there was a difference in the diameter of the first treatment in the months of October of August. In the third treatment, there were no significant differences and when the plant was evaluated in an area without green manure, all treatments showed a significant difference in the months analysed.

The Guazuma ulmifolia showed no significant difference for height and diameter (Tables 5 and 6). These plants are not necessarily resistant to longer periods without water, being characterized as a medium tree, semi-deciduous, with an umbelliform crown. Its trunk is of very extended branches, horizontal and even hanging, always green and branched from the base (Rojas-Rodríguez \& Torres-Córdoba, 2019).

The Byrsonima crassifolia showed no significant difference in relation to height. In diameter in all two treatments and in the last one, significant differences were observed in the months of December, January, and February. For the Hysocalymma scaberrimum Pohl. (Lythraceae), there were differences in height in the first three treatments in July. The plant without green manure has a significant difference between September 2013 and March (Table 9). Regarding the diameter, the first three treatments differ between July and August and September and June (Table 10).

There was no difference in height when Apeiba was intercropped with Cajanus cajan. From October to February and between May and August there was a difference. Moreover, differences were observed from September to March and from May to August. The single plant showed a significant difference from October to February and from May to August (Table 11). For diameter, the month of June was the only with a significant difference in the first two periods for the diameter of the Apeiba, in the third there was no difference in any month and in the fourth there was in March, May and June (Table 12). The use of green manure was tested in the production of organic tomatoes. The species used were: Crotalaria juncea, Avena sativa, Stizolobium aterrimum, Canavalia ensiformis e Lolium multiflorum. In this study, the differences in the values found were due, mainly to the cultivars (Toledo et al., 2011).

Regarding the microbiological properties of the soil, in some cases, depending on the evaluation time, green manures can present different results. In one evaluation of seven legumes green manure were able to maintain the total $\mathrm{C}$ and $\mathrm{N}$ contents in the soil after corn harvest. While forage legumes had higher metabolic stress than either grain or green manure ones, all the green manures presented lower stresses than either control treatment, indicating increased efficiency in organic matter decomposition (Barros et al., 2020).

In evaluations of the effects of the type of soil management and cover crops on microbial indicators of soil quality, an experiment was carried out under field conditions, with common beans and corn, grown under no-tillage (NT) and conventional soil preparation, after Crotalaria, Mucuna pruriens, Cajanus cajan, Canavalia ensiformis, Sorghum bicolor and fallow (spontaneous plants), in which cover crops had less evident effect on microbiological soil quality indicators, compared to soil management systems (Ferreira et al., 2011).

In the semi-arid region of Paraiba, Brazil, the effect of organic fertilization on the arbuscular mycorrhizal fungi community in systems intercropped with corn, beans and cotton was evaluated over two years. It was not possible to identify a better treatment in terms of spore density, mycorrhizal colonization and glomalin content, with a significant effect of incorporations in most treatments when compared to control (Sousa et al., 2012). According to Tavares et al., (2011): "soil organisms play an important role in organic crops of Crotalaria juncea (Fabaceae) and are associated with the natural conservation of the environment".

In the evaluation of the use of these plants together with sugarcane, the effect of the previous cultivation of legumes on the productivity and profitability of sugarcane was studied, where the biomass productivity, the accumulation of nutrients of the legumes were determined, the natural occurrence of arbuscular mycorrhizal fungi, as well as the effect of legumes on the population of nematodes of the genus Pratylenchus to sugar cane. After five sugarcane cuts, the best performance was noted in the treatment with previous cultivation of crotalaria juncea, which promoted increments of $30 \%$ and $35 \%$ in the productivity of stalks and sugar respectively and the best economic performance (Ambrosano et al., 2011).

In another study with the use of Crotalaria juncea in a cabbage cultivation area, the legume roots did not represent a significant $\mathrm{N}$ content, suggesting both a low $\mathrm{N}$ supply by the roots and $\mathrm{N}$ immobilization in the 
soil organic matter and microbial biomass (Vargas et al., 2013). When evaluating the effect of different organic fertilizers in association or not with green manure in the production of leaves of Ocimum selloi Benth., a Brazilian plant, no increase in results was observed due to the association with Crotalaria juncea (Morais \& Barbosa, 2012).

Species such as Crotalaria juncea and Canavalia ensiformis were used in a study that had as main objective the evaluation of the influence of cover plants and planting spacing in the control of soil, water, and nutrient losses due to water erosion, aiming at soil conservation (Cardoso et al., 2012). Something studied was the effect of the preceding green coverages on the need for nitrogen fertilization of the corn crop, during different agricultural years under no-tillage system.

Corn cultivation after Crotalaria showed better performance and less demand for nitrogen fertilization, when compared to cultivated after millet (Leal et al., 2013). In the wheat crop, the use of different vegetable coverings can reduce the need for nitrogen fertilizers in cover, and the cultivation of wheat in succession to the plant residues of Cajanus cajan, crotalaria and Pennisetum glaucum (L.) $R$. Br next to the Crotalaria can present higher grain productivity than in succession to fallow (Melero et al., 2013).

When evaluating the production of phytomass and the rates of decomposition and release of macronutrients and silicon, in the plant residues of Crotalária and Pennisetum glaucum (L.) R. Br, in single and intercropped cultivation, a greater accumulation of Ca was observed by Crotalária (Soratto et al., 2012), something interesting to be evaluated, because that way, costs can be reduced. In Figure 1 it is possible to see the species with the best height $(\mathrm{cm})$ and diameter $(\mathrm{mm})$ development was the Guazuma ulmifolia, which was the plant with no significant difference at 5\% probability, with the presence of green manures.

Table 11. Apeiba albiflora height $(\mathrm{cm})$ in single cultivation and intercropped at different times of evaluation.

\begin{tabular}{|c|c|c|c|c|c|c|c|c|c|c|c|c|}
\hline \multirow{2}{*}{ Treatments } & \multicolumn{4}{|c|}{ First year } & \multicolumn{8}{|c|}{ Second year } \\
\hline & Sept. & Oct. & Nov. & Dec. & Jan. & Feb. & Mar. & Apr. & May & Jun. & Jul. & Aug. \\
\hline $\begin{array}{l}\text { Apeiba albiflora/ } \\
\text { Cajanus cajan }\end{array}$ & $214,00 \mathrm{Aa}$ & $245,00 \mathrm{Aa}$ & $245,00 \mathrm{Aa}$ & $258,50 \mathrm{Aa}$ & $257,00 \mathrm{Aa}$ & $272,00 \mathrm{Aa}$ & $292,50 \mathrm{Aa}$ & $306,00 \mathrm{Aa}$ & $325,50 \mathrm{Aa}$ & $325,00 \mathrm{Aa}$ & $325,00 \mathrm{Aa}$ & $337,50 \mathrm{Aa}$ \\
\hline $\begin{array}{l}\text { Apeiba albiflora/ } \\
\text { Estilosanthes capitata }\end{array}$ & $167,50 \mathrm{Aa}$ & $178,50 \mathrm{ABa}$ & $178,50 \mathrm{ABa}$ & $197,50 \mathrm{ABa}$ & $200,50 \mathrm{ABa}$ & $212,50 \mathrm{ABa}$ & $212,50 \mathrm{Aa}$ & $220,00 \mathrm{Aa}$ & $231,50 \mathrm{ABa}$ & $232,50 \mathrm{Aa}$ & $242,50 \mathrm{Aa}$ & $250,00 \mathrm{ABa}$ \\
\hline $\begin{array}{l}\text { Apeiba albiflora/ } \\
\text { Crotalaria juncea }\end{array}$ & $156,00 \mathrm{Abc}$ & $224,00 \mathrm{ABabd}$ & $224,00 \mathrm{ABabd}$ & $144,50 \mathrm{Bc}$ & $142,00 \mathrm{Bc}$ & $151,50 \mathrm{Bbc}$ & 277,50 Aab & $302,50 \mathrm{Aa}$ & $310,00 \mathrm{ABa}$ & $326,50 \mathrm{Aa}$ & $327,50 \mathrm{Aa}$ & $305,50 \mathrm{ABa}$ \\
\hline Apeiba albiflora & $135,00 \mathrm{Aa}$ & $142,50 \mathrm{Ba}$ & $142,50 \mathrm{Ba}$ & $226,00 \mathrm{ABa}$ & $240,00 \mathrm{ABa}$ & $249,50 \mathrm{ABa}$ & $191,50 \mathrm{Aa}$ & $214,00 \mathrm{Aa}$ & $216,50 \mathrm{Ba}$ & $229,00 \mathrm{Aa}$ & $229,00 \mathrm{Aa}$ & $229,00 \mathrm{Ba}$ \\
\hline
\end{tabular}

* Values followed by the same letter, uppercase in the column and lowercase in the row, do not differ by Tukey's test at $5 \%$ probability.

Table 12. Apeiba albiflora diameter $(\mathrm{mm})$ in single cultivation and intercropped at different times of evaluation.

\begin{tabular}{|c|c|c|c|c|c|c|c|c|c|c|c|c|}
\hline \multirow{2}{*}{ Treatments } & \multicolumn{4}{|c|}{ Firstyear } & \multicolumn{8}{|c|}{ Second year } \\
\hline & Sept & Oct & Nov. & Dec. & Jan. & Feb. & Mar. & $A p r$ & May & Jun. & Jul. & Aug. \\
\hline $\begin{array}{l}\text { Apeiba albiflora/ } \\
\text { Cajanus cajan }\end{array}$ & $55,79 \mathrm{Aa}^{*}$ & $55,45 A a$ & $55,45 \mathrm{Aa}$ & $61,23 A a$ & $71,32 \mathrm{Aa}$ & $71,32 \mathrm{Aa}$ & $73,33 \mathrm{Aa}$ & $84,21 \mathrm{Aa}$ & $76,30 \mathrm{Aa}$ & $81,48 \mathrm{ABa}$ & $91,16 A a$ & $91,25 \mathrm{Aa}$ \\
\hline $\begin{array}{l}\text { Apeiba albifiora/ } \\
\text { Estilosanthes capitata }\end{array}$ & $46,54 \mathrm{Aa}$ & $45,57 \mathrm{Aa}$ & $45,57 \mathrm{Aa}$ & $56,20 \mathrm{Aa}$ & $56,20 \mathrm{Aa}$ & $67,30 \mathrm{Aa}$ & $72,41 \mathrm{Aa}$ & $74,90 \mathrm{Aa}$ & $74,90 \mathrm{Aa}$ & $75,10 \mathrm{ABa}$ & $77,78 \mathrm{Aa}$ & $78,51 \mathrm{Aa}$ \\
\hline $\begin{array}{l}\text { Apeiba albiflora/ } \\
\text { Crotalaria juncea }\end{array}$ & $30,72 \mathrm{Aa}$ & $32,44 \mathrm{Aa}$ & $32,44 A a$ & $34,77 A a$ & $36,68 \mathrm{Aa}$ & $37,23 \mathrm{Aa}$ & $76,74 \mathrm{Aa}$ & $87,04 A a$ & $90,85 \mathrm{Aa}$ & $92,89 A a$ & $96,36 A a$ & $96,36 \mathrm{Aa}$ \\
\hline Apeiba albiflora & $25,01 \mathrm{Aa}$ & $26,27 \mathrm{Aa}$ & $26,27 \mathrm{Aa}$ & $33,49 \mathrm{Aa}$ & $42,59 \mathrm{Aa}$ & $42,87 \mathrm{Aa}$ & $43,11 \mathrm{ABa}$ & $48,44 \mathrm{Aa}$ & $51,10 \mathrm{Ba}$ & $51,23 \mathrm{Ba}$ & $55,84 A a$ & $55,84 \mathrm{Aa}$ \\
\hline
\end{tabular}

* Values followed by the same letter, uppercase in the column and lowercase in the row, do not differ by Tukey's test at $5 \%$ probability. 
Figure 1. In green, the plant with the best development, which was the Guazuma ulmifolia (in green). The worst development had Dipteryx alata (in dark blue).

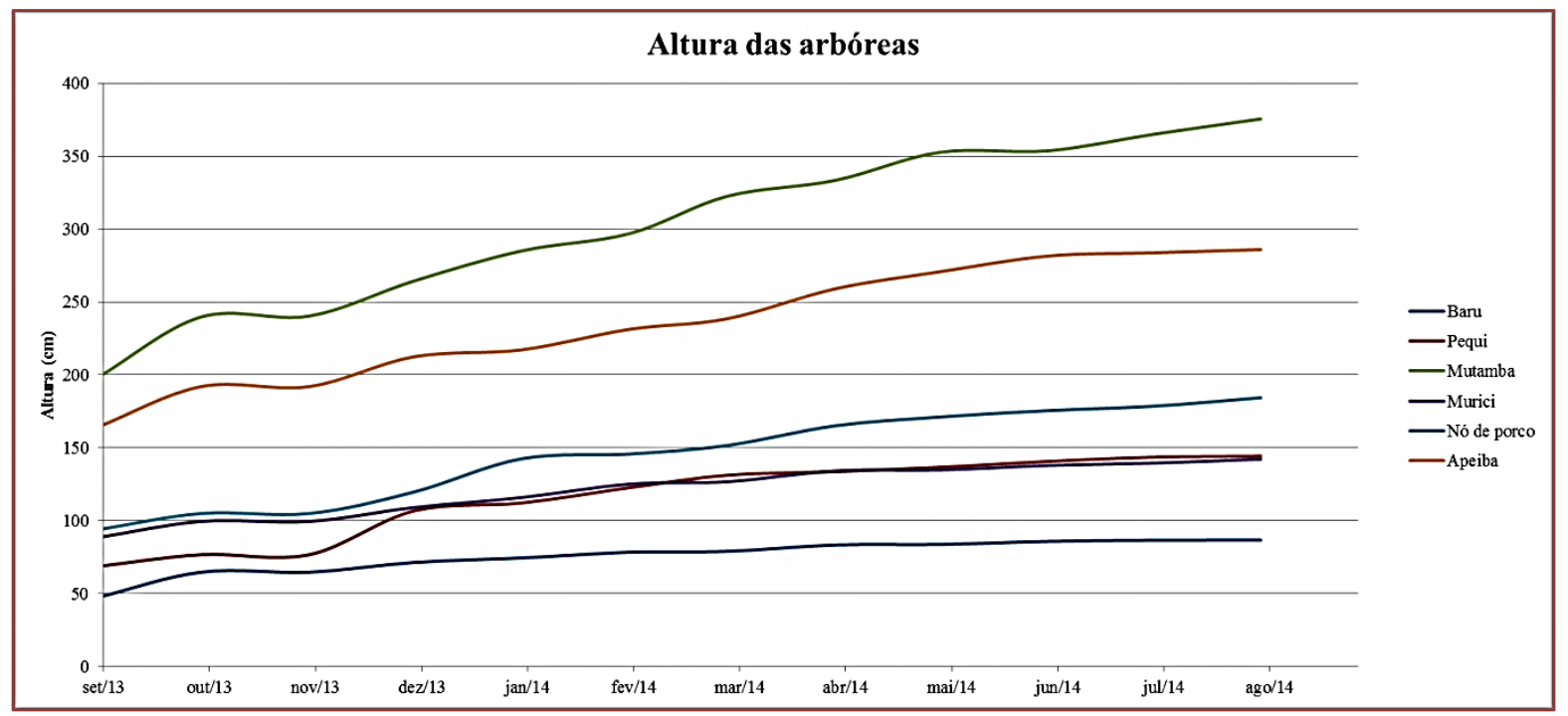

Figure 2. Guazuma ulmifolia had the best trunk widening, with Dipteryx alata (in green) the lower development (in dark blue).

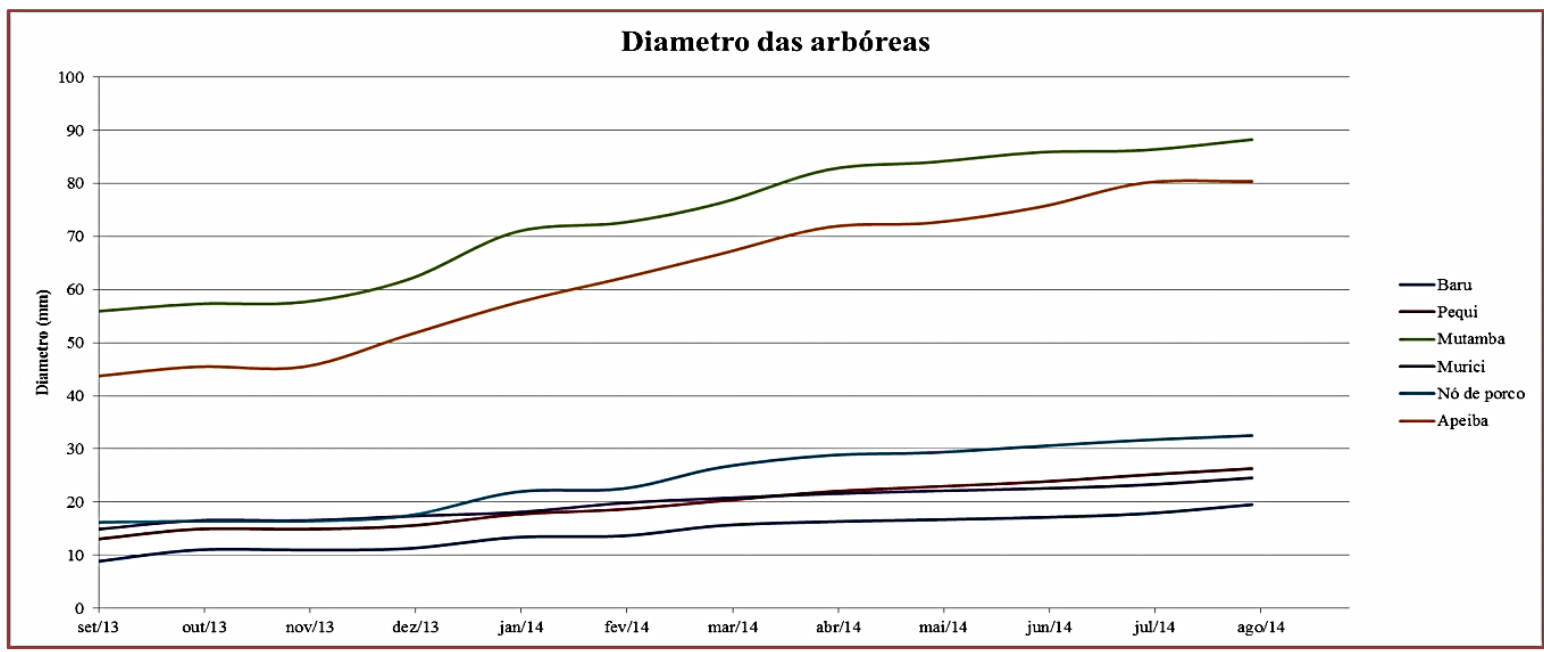

The use of Dipteryx alata has different benefits for the industry and human use. It was discovered that the oil of this plant has a significant content of total tocopherols (vitamin E) and desirable fatty acid composition from a nutritional point of view. It does not oxidize with the cold extraction process and have similar coloration in relation to other studied oils. This oil has already been used in regional culinary, in some places in Brazilian savanna. However, this oil used as raw or as an ingredient has the potential to be disseminated, becoming part of the diet in other regions of Brazil and other countries, contributing to the sustainability of the Cerrado (Siqueira et al., 2016).

Brazil has a mix of policy instruments in place to manage forests. The mix includes the regulatory framework (with key elements being the National Environment Policy and the Forest Code), law enforcement, indigenous territories, protected areas (which are supported by intergovernmental fiscal transfers systems from state to municipal governments as well), forest monitoring systems, and payments for environmental services (Tacconi et al., 2019). Although the existence of these legal instruments is necessary for environmental sustainability of green areas, the government needs to support the nature preservation, avoiding policies which drive deforestation. 


\section{CONCLUSIONS}

1. The use of the studied plants proved to be a good option for agroecological production. In addition to being efficient in enriching the soil, green manures are affordable alternatives for pest control.

2. In future studies, the substitution of the Caryocar Brasiliense is recommended, and its development is slow for what is sought. The development of the Guazuma ulmifolia showed no significant difference in any of the months evaluated.

3. It is interesting to incorporate green fertilizers into the soil, something that has not been done, because in addition to fixing nutrients through the roots, protecting seedlings against invasive species was one of the purposes of leaving green fertilizers in the area until the end of the season.

\section{REFERENCES}

[1] Ambrosano, e. J; Cantarella, H; Ambrosano, G. M. B; Schammas, E. A; Dias, F. L. F; Rossi, F; Trivelin, P. C. O; Muraoka, T; Sachs, R. C. C; Azcón, R. 2011. Sugarcane yield on consecutive cuts after pre-cultivation of green manure species. Bragantia, Campinas, Volume. 70, n. 4, p. 810-818.

[2] Barros, V. D. C., Lira Junior, M. A., Fracetto, F. J. C., Fracetto, G. G. M., Ferreira, J. S., Barros, D. J., Silva Júnior, A. F. 2020. Effects of different legume green manures on tropical soil microbiology after corn harvest. Bragantia, Campinas, Volume. 79, n. 4, p. 505-515. DOI: https://doi.org/10.1590/1678-4499.20200262

[3] Brazil. Decree no 8.972 of January 23, 2017. Institutes the National Policy for the Recovery of Native Vegetation. Available in: http://www.planalto.gov.br/ccivil_03/_ato20152018/2017/decreto/d8972.htm\#: :text=DECRET0\%20N\%C2\%BA\%208.972\%2C\%20DE\%2023,que\%20lhe\%20con fere $\% 20$ o\% 20art. Access: 22 Mar. 2021.

[4] Brazil. Law 12.651, of May 25, 2012. Provides for the protection of native vegetation; amends Laws 6,938, of August 31, 1981, 9,393, of December 19, 1996, and 11,428, of December 22, 2006; repeals Laws 4,771, of September 15, 1965, and 7,754, of April 14, 1989, and Provisional Measure No. 2,166-67, of August 24, 2001; and makes other arrangements. Available in: http://www.planalto.gov.br/ccivil_03/_Ato2011-2014/2012/Lei/L12651compilado.htm. Access: 22 Mar. 2021.

[5] Cardoso, D. P; Silva, M. L. N; Carvalho, G. J; Freitas, D. A. F; Avanzi, J. C. 2012. Cover crops to control soil, water, and nutrient losses by water erosion. Revista Brasileira de Engenharia Agrícola e Ambiental, Campina Grande, Volume. 16, n. 6, p. 632-638. DOI: https://doi.org/10.1590/S1415-43662012000600007

[6] Demolin-Leite, G. L., Santos-Veloso, R. V., Alvarenga-Soares, M., Fernandes, G. W., Cola-Zanuncio, J., AlvesOliveira, N., Santos Junior, V. C. 2020. Does environmental diversity affect hymenopteran galling insects and their natural enemies on Caryocar brasiliense trees (Caryocaraceae)? Revista Colombiana de Entomología, Volume. 46, n.1. DOI: https://doi.org/10.25100/socolen.v46i1.8546

[7] Faustino, L. L., Marciano, C. R., Andrade, G. R. P. 2021. Physical quality of soil under secondary forest, leguminous trees, and degraded pasture. Pesquisa Agropecuária Brasileira, Volume. 56, p. 1-10. DOI: http://10.1590/S1678-3921.pab2021.v56.02023

[8] Ferreira, E. M., Andraus, M. P., Tsai, H. M., Cardoso, A. A., Leandro, W. M. 2018. Permanent preservation area revegetated with tree species and green manures. Engenharia Sanitária e Ambiental, Volume. 23, n. 2. DOI: http://doi.org/10.1590/s1413-41522018146568

[9] Ferreira, E. P. B; Wendland, A; Didonet, A. D. 2011. Microbial biomass and enzyme activity of a Cerrado Oxisol under agroecological production system. Bragantia, Campinas, Volume. 70, n. 4, p. 899-907. DOI: http://dx.doi.org/10.1590/S0006-87052011000400024

[10] Labigaline, I., Sala, F. C., Gomes, T. M., Corsini, I., Rossi, F. Green manure, Trichoderma asperellum and homeopathy in cultivating the biquinho pepper. 2020. Revista Ciência Agronômica, Volume. 51, n. 3. DOI: https://doi.org/10.5935/1806-6690.20200054

[11] Leal, A. J. F; Lazarini, E; Rodrigues, L. R; Marcandalli, L. H. 2013. Forms of lime application, cover crops and nitrogen rates in maize. Revista Brasileira de Ciência do Solo, Volume. 37, n. 2, p. 491-50. DOI: https://doi.org/10.1590/S0100-06832013000200020

[12] Leite, G. L. D, Veloso, R. V. S., Zanuncio, J. C., Fernandes, L. A., Almeida, C. I. M. 2006. Phenology of Caryocar brasiliense in the Brazilian Cerrado Region. Forest Ecology and Management, Volume. 236, no. 2-3, pp. 286-294. http://dx.doi.org/10.1016/j.foreco.2006.09.013

[13] Melero, M. M; Gitti, D. C; Arf, O; Rodrigues, R. A. F. 2013. Cover crops and nitrogen doses in wheat under notillage system. Pesquisa Agropecuária Tropical, Goiânia, Volume. 43, n. 4, p. 343-353. DOI: 


\section{https://doi.org/10.1590/S1983-40632013000400001}

[14] Miranda, R. F., Alves Júnior, J., Casaroli, D., Evangelista, A. W. P. 2019. Leaf temperature and transpiration of pequi trees with and without water restriction. Engenharia Agrícola, Jaboticabal, Volume. 39, n. 5, 579-585. DOI: https://doi.org/10.1590/1809-4430-eng.agric.v39n5p579-585/2019

[15] Morais, L. A. S \& Barbosa, A. G. 2012. Influence of green manure and different organic manure on production of aereal phytomass of Ocimum selloi. Revista Brasileira de Plantas Medicinais, Botucatu, Volume. 14, n. spe. p. $246-$ 249. DOI: https://doi.org/10.1590/S1516-05722012000500020

[16] Rojas-Rodríguez, F \& Torres-Córdoba, G. 2019. Trees of the Central Valley of Costa Rica: reproduction of Guácimo ternero (Guazuma ulmifolia Lam.). Revista Forestal Mesoamericana Kurú, Volume.16, n.39, Cartago, Jul./Dec. 2019. DOI: http://dx.doi.org/10.18845/rfmk.v16i39.4431

[17] Saraiva, D. F., Botelho, S. A., de Paula, C. C., Vinícius-Silva, R., Morais, P. J., de Melo, L. A. 2020. Native Brazilian grass species with potential for revegetation of degraded lands, surveyed from a Ferruginous Campo Rupestre topsoil. Hoehnea, Volume. 47, p. 1-11, http://dx.doi.org/10.1590/2236-8906-112/2019

[18] Silva, B. B; Mendes, F. B. G; Kageyama, P. Y. Economic, social, and environmental development of family farming through Agroecological Knowledge. Crotalárias. Available in: <http://www.lcb.esalq.usp.br/extension/DESAAFCA/crotalarias.pdf>. Access: 22 Mar. 2021.

[19] Siqueira, A. P. S., Castro, C. F. S., Silveira, E. V., Lourenço, M. F. C. 2016. Chemical quality of Baru almond (Dipteryx alata oil). Ciência Rural, Santa Maria, Volume. 46, n. 10, p. 1865-1867. D0I: http://dx.doi.org/10.1590/0103-8478cr20150468

[20] Soratto, R. P; Crusciol, C. A. C; Costa, C. H. M; Ferrari Neto, J; Castro, G. S. A. 2012. Production, decomposition, and nutrient cycling in residues of sunnhemp and pearl millet in monocropped and intercropped systems. Pesquisa Agropecuária Brasileira, Brasília, Volume. 47, n. 10, p. 1462-1470. DOI: https://doi.org/10.1590/S0100204X2012001000008.

[21] Sousa, C. S; Menezes, R. S. C; Sampaio, E. V. S. B; Oehl, F; Maia, L. C; Garrido, M. S; LIMA, F. S. 2012. Occurrence of arbuscular mycorrhizal fungi after organic fertilization in maize, cowpea, and cotton intercropping systems. Acta Scientiarum. Agronomy, Maringá, Volume. 34, n. 2, p. 149-156. DOI: https://doi.org/10.4025/actasciagron.v34i2.13143

[22] Tacconi, L., Rodrigues, R. J., Maryudi, A. 2019. Law enforcement and deforestation: Lessons for Indonesia from Brazil. Forest Policy and Economics, Volume 108. DOI: https://doi.org/10.1016/j.forpol.2019.05.029

[23] Tavares, W. S; Cruz, I; Silva, R. B; Figueiredo, M. L. C; Ramalho, F. S; Serrão, J. E; Zanuncio, J. C. 2011. Soil organisms associated to the weed suppressant Crotalaria juncea (fabaceae) and its importance as a refuge for natural enemies. Planta Daninha, Viçosa, Volume. 29, n. 3, p. 473-479.

[24] Toledo, D. S; Costa, C. A; Bacci, L; Fernandes, L. A; Souza, M. F. 2011. Production, and quality of tomato fruits under organic management. Horticultura Brasileira, Brasília, Volume. 29, n. 2, p. 253-257. DOI: https://doi.org/10.1590/S0102-05362011000200022

[25] Vargas, T. O; Diniz, E. R; Santos, R. H. S; Urquiaga, S; Cecon, P. R. 2013. Nitrogen contributions of legume roots to cabbage nutrition. Scientia Agricola, Piracicaba, Volume. 70, n. 6, p. 415-421. 


\title{
Capítulo 20
}

Google Earth Engine aplicado análise multitemporal de área afetadas pela instalação da usina de Belo Monte - Pa

\author{
Juliana Tamires Ferreira Kizahy Nagem \\ Maria Luiza de Castro Garcia \\ Karen Patrícia Macedo Cesário \\ Lucas Daniel Noronha Ferreira \\ Mozart dos Santos Silva \\ Patrick Rafael Silva Correa
}

Resumo: As ferramentas de geoprocessamento estão em constante evolução e são de suma importância para o monitoramento de paisagens. 0 Google Earth Engine - GEE se apresenta como um novo instrumento e poderoso para realizar processamento digital de imagens, uma vez seu armazenamento é em nuvem e dispensa pré-processamentos. Nesse sentido, o este trabalho buscou aplicar o GEE na análise multitemporal no intervalo de 10 anos em áreas afetadas pela instalação da Usina de Belo Monte - PA, identificando os impactos desse empreendimento nas áreas de estudo. Verificou-se grandes mudanças nas paisagens no período de 10 anos, com grandes áreas sofrendo alagamentos. 0 GEE é um importante aliado para as áreas de informação geográfica, classificação e monitoramento de regiões de interesse, podendo ser utilizados para analisar o comportamento populacional, o desmatamento e planejar o desenvolvimento das cidades.

Palavras-chave: Geoprocessamento - Google Earth Engine - Geotecnologia - Cartografia - Sensoriamento Remoto 


\section{INTRODUÇÃO}

Este trabalho tem como objetivo realizar a classificação do uso e cobertura da terra em forma de análise multitemporal no período de 10 anos (intervalo de 2010 à 2020) de duas áreas afetadas pela instalação da Usina Hidrelétrica de Belo Monte, localizadas próximas ao Rio Xingu, interior do Estado do Pará. Vale destacar também que se visa informar aspectos diversos da área como sua localização com coordenadas dos limites, município, estado, tipo de acesso e campo de pouso, e as características de sua problemática com o mapeamento das modificações em 10 anos, quantificação de desmatamento ou alagamento, rios impactados, lagos artificiais criados, barragens, estruturas construtivas e estimar indenização no caso de áreas alagadas.

Para as classificações, serão adotadas classes como as áreas antropotizadas cobertura vegetal, hidrografia e outros.

As áreas antropotizadas que englobam todas as regiões que tenham sofrido com a ação humana, tendo suas características originais modificadas, como estradas, solo exposto, área agrícola, pasto, mineração e ocupação urbana.

A cobertura vegetal envolve formas de vegetação natural ou cultivada, como vegetação arbórea, arbustiva ou gramínea, natural primária, regenerada ou em processo de regeneração. A hidrografia trata das águas, como oceanos, rios, córregos e corpos d'água em geral.

\section{MATERIAIS E MÉTODOS}

Para obtenção dos resultados objetivados foi utilizado o software livre online baseado em nuvem Google Earth Engine - GEE, no seu editor de código, uma plataforma capaz de processar imagens de satélite na nuvem de forma distribuída e rápida, permitindo que ferramentas de alto desempenho interpretem e analisem uma gama de informações, as quais são visualizadas em mapas (GANEN,2017).

Foram importadas imagens dos satélites Landsat 5 para o ano de 2010 e Landsat 8, para o ano de 2020, ambos com resolução espacial de $30 \mathrm{~m}$ na faixa do visível, oriundas do United States Geological Survey USGS, dessa forma contendo cenas ortorretificadas, georreferenciadas e com correção atmosférica.

Foram importadas as imagens, as classes, o shapefile do município e uma geometria que o englobando a área de interesse. Em seguida, foram aplicados filtros para geração da imagem recortada, coletadas as amostras para classificação. 0 código foi rodado e exportado em formato TIFF, sendo posteriormente executado no software livre de sistema de informações geográficas Qgis 3.14 Pi para geração de mapas categorizados por classe, além do cálculo de sua área em $\mathrm{km}^{2} .0$ mesmo processo foi realizado nos dois códigos, com discrepância apenas no ano escolhido.

\section{RESULTADOS E DISCUSSÕES}

A área 1 possui 24 vértices e suas coordenadas estão dispostas a seguir (Tabela 1):

Tabela 1: Coordenadas da Área 1

\begin{tabular}{|c|c|c|c|c|c|}
\multicolumn{7}{c|}{ Área 1 - Vitória do Xingu } \\
Ponto & X (Long) & Y (Lat) & Ponto & X (Long) & Y (Lat) \\
\hline P1 & $-51,80952$ & $-3,12929$ & P13 & $-51,818532$ & $-3,352841$ \\
\hline P2 & $-51,751099$ & $-3,127563$ & P14 & $-51,852558$ & $-3,350067$ \\
\hline P3 & $-51,738249$ & $-3,201295$ & P15 & $-51,868558$ & $-3,334918$ \\
\hline P4 & $-51,737702$ & $-3,202825$ & P16 & $-51,868612$ & $-3,30439$ \\
\hline P5 & $-51,73633$ & $-3,20467$ & P17 & $-51,864206$ & $-3,298205$ \\
\hline P6 & $-51,72108$ & $-3,254302$ & P18 & $-51,863407$ & $-3,285196$ \\
\hline P7 & $-51,720714$ & $-3,257869$ & P19 & $-51,86277$ & $-3,270802$ \\
\hline P8 & $-51,73812$ & $-3,285953$ & P20 & $-51,856444$ & $-3,252462$ \\
\hline P9 & $-51,744549$ & $-3,294969$ & P21 & $-51,840026$ & $-3,245506$ \\
\hline P10 & $-51,754799$ & $-3,30553$ & P22 & $-51,821157$ & $-3,234622$ \\
\hline P11 & $-51,78014$ & $-3,322426$ & P23 & $-51,838782$ & $-3,210269$ \\
\hline P12 & $-51,788141$ & $-3,349832$ & P24 & $-51,848357$ & $-3,179158$ \\
\hline
\end{tabular}

Fonte: Elaborado pela autora. 
Essa zona está localizada no município de Vitória do Xingu no Estado do Pará, e não se encontra em nenhuma área especial como unidades de conservação ou terras indígenas, e sim é uma área afetada pela instalação de barragem da Usina Hidrelétrica de Belo Monte, sob a qual é possível ter acesso através da rodovia federal BR-230, conhecida por Rodovia Transamazônica.

O campo de pouso mais próximo é o Aeroporto de Altamira, localizado há quase $50 \mathrm{~km}$ de distância.

Por ser uma área que recebeu o sistema de barramento da usina em questão o problema mais notório é o grande alagamento já esperado deste tipo de empreendimento, modificando drasticamente a paisagem da área no intervalo estipulado, conforme pode-se em sua representação gráfica no mapa da Figura 1.

As alterações que ocorreram no intervalo de 10 anos podem ser verificadas na tabela 2, que mensurou a área alterada e sua porcentagem correspondente. A análise da Figura 1 em consonância com a Tabela 2 auxiliam no entendimento das modificações que essa área sofreu em decorrência da instalação da Usina Hidrelétrica de Belo Monte.

Figura 1: Comparação da Área 1 no intervalo de 10 anos

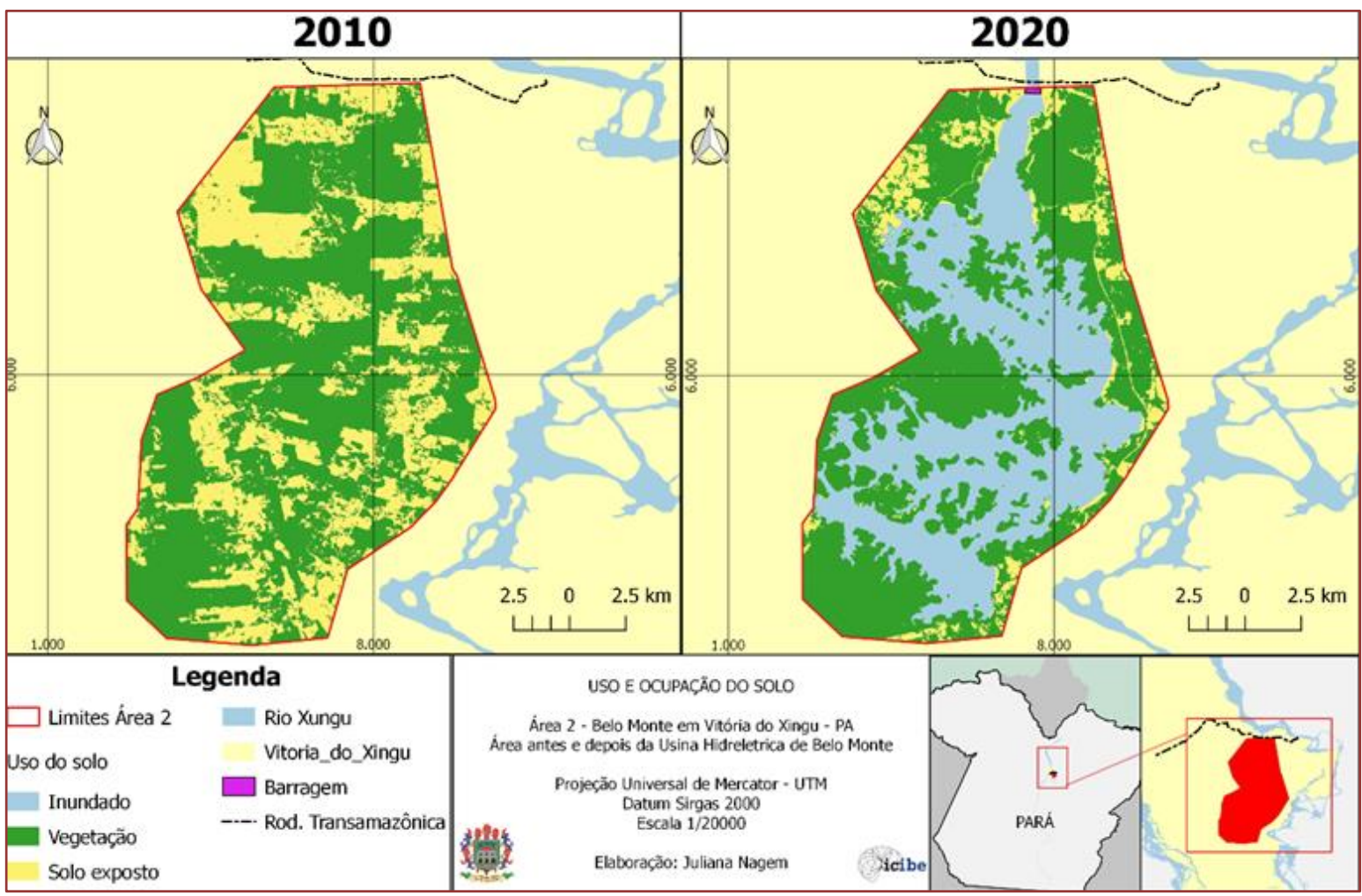

Fonte: Elaborado pela autora.

Tabela 2: Quantificação das modificações da Área 1

\begin{tabular}{|c|c|c|c|c|c|}
\hline \multirow{2}{*}{ Tipo } & \multicolumn{3}{|c|}{$\begin{array}{l}\text { Área } 1 \text { - Vitória do Xingu } \\
\text { Área em km² }\end{array}$} & \multicolumn{2}{|c|}{$\%$ Correspondente } \\
\hline & 2010 & 2020 & Diferença & 2010 & 2020 \\
\hline Água & & 113,868 & 113,868 & $0,00 \%$ & $40,91 \%$ \\
\hline Vegetação & 176,2000 & 142,3533 & $-33,84677$ & $63,32 \%$ & $51,15 \%$ \\
\hline Solo & 102,0761 & 22,05485 & $-80,02123$ & $37 \%$ & $7,94 \%$ \\
\hline Total & 278,2761 & 278,276 & 0 & $100,00 \%$ & $100,00 \%$ \\
\hline
\end{tabular}

Fonte: Elaborado pela autora. 
Portanto, a instalação da barragem no ponto $\mathrm{P}(\mathrm{x}, \mathrm{y})=-51.77554 ;-3.12979$, afetou o Rio Xingu causou diversas modificações na Área 1, em especial o alagamento de $113,868 \mathrm{~km}^{2}$ ou 11386,8 ha que corresponde a mais de $40 \%$ dessa região.

Além disso, a taxa de solo exposto variou de $37 \%$ para apenas $7,94 \%$, o que pode se justificar pelo isolamento da área. E a queda na porcentagem de vegetação de 63,32\% para aproximadamente 51\% devese a inundação de grande parte da área 1.

Para estimar os o valor da indenização pela região alagada, considerou-se que cada hectare está avaliado no valor de $\mathrm{R} \$ 12.500,00$, assim o valor total da indenização da área alagada seria de $\mathrm{R} \$ 141.250 .000,00$.

Já a Área 2, apresenta as seguintes coordenadas em seus vértices:

Tabela 3: Coordenadas x e y da Área 2

\begin{tabular}{|c|c|c|c|c|c|}
\multicolumn{7}{c|}{ Área 2 - Altamira } \\
Ponto & X (Long) & Y (Lat) & Ponto & X (Long) & Y (Lat) \\
\hline P1 & $-52,027688$ & $-3,335579$ & P10 & $-52,031854$ & $-3,377129$ \\
\hline P2 & $-52,028033$ & $-3,336068$ & P11 & $-52,03173$ & $-3,377584$ \\
\hline P3 & $-52,032195$ & $-3,341393$ & P12 & $-52,028797$ & $-3,380137$ \\
\hline P4 & $-52,032632$ & $-3,350939$ & P13 & $-52,022987$ & $-3,381473$ \\
\hline P5 & $-52,029038$ & $-3,354597$ & P14 & $-52,022404$ & $-3,381573$ \\
\hline P6 & $-52,029516$ & $-3,359057$ & P15 & $-52,020328$ & $-3,383456$ \\
\hline P7 & $-52,032948$ & $-3,36304$ & P16 & $-52,073852$ & $-3,412897$ \\
\hline P8 & $-52,033689$ & $-3,366916$ & P17 & $-52,090988$ & $-3,343022$ \\
\hline P9 & $-52,032563$ & $-3,370587$ & & & \\
\hline
\end{tabular}

Fonte: Elaborado pela autora.

A área 2 encontra-se no município de Altamira no Estado do Pará e é mais umas da área que foi afetada pela construção da Usina Hidrelétrica de Belo Monte, e por estar há aproximadamente 35km de uma de suas barragens, essa zona também sofreu com o alagamento.

O acesso a Área 2 se dá por meio da Rodovia Federal BR - 158 e seu campo de pouso mais próximo é o Aeroporto de Altamira que está a uma distância de aproximadamente $20 \mathrm{~km}$, e não está situada em nenhuma área especial como unidade de conservação da natureza ou terras indígenas.

0 alagamento é a característica mais notória da Área 2, como pode-se observar na Tabela 4:

Tabela 4: Quantificação das modificações na Área 3

\begin{tabular}{|l|c|c|c|c|c|}
\multicolumn{7}{c}{ Área 2- Altamira } \\
\multicolumn{1}{c}{ Tipo } & 2010 & 2020 & Diferença & 2010 & 2020 \\
\hline Água & & 8,41213 & 8,4121296 & $0,00 \%$ & $20,55 \%$ \\
\hline Vegetação & 27,4859 & 22,9287 & $-4,557215$ & $67,17 \%$ & $56,03 \%$ \\
\hline Solo & 13,4347 & 9,57983 & $-3,854915$ & $33 \%$ & $23,42 \%$ \\
\hline Total & 40,9206 & 40,9206 & 0 & $100,00 \%$ & $100,00 \%$ \\
\hline
\end{tabular}

Fonte: Elaborado pela autora.

As mudanças na paisagem da Fazenda Fortaleza no intervalo de 10 anos estão representadas graficamente na Figura 2: 
Figura 2: Comparação da Área 3 no intervalo de 10 anos

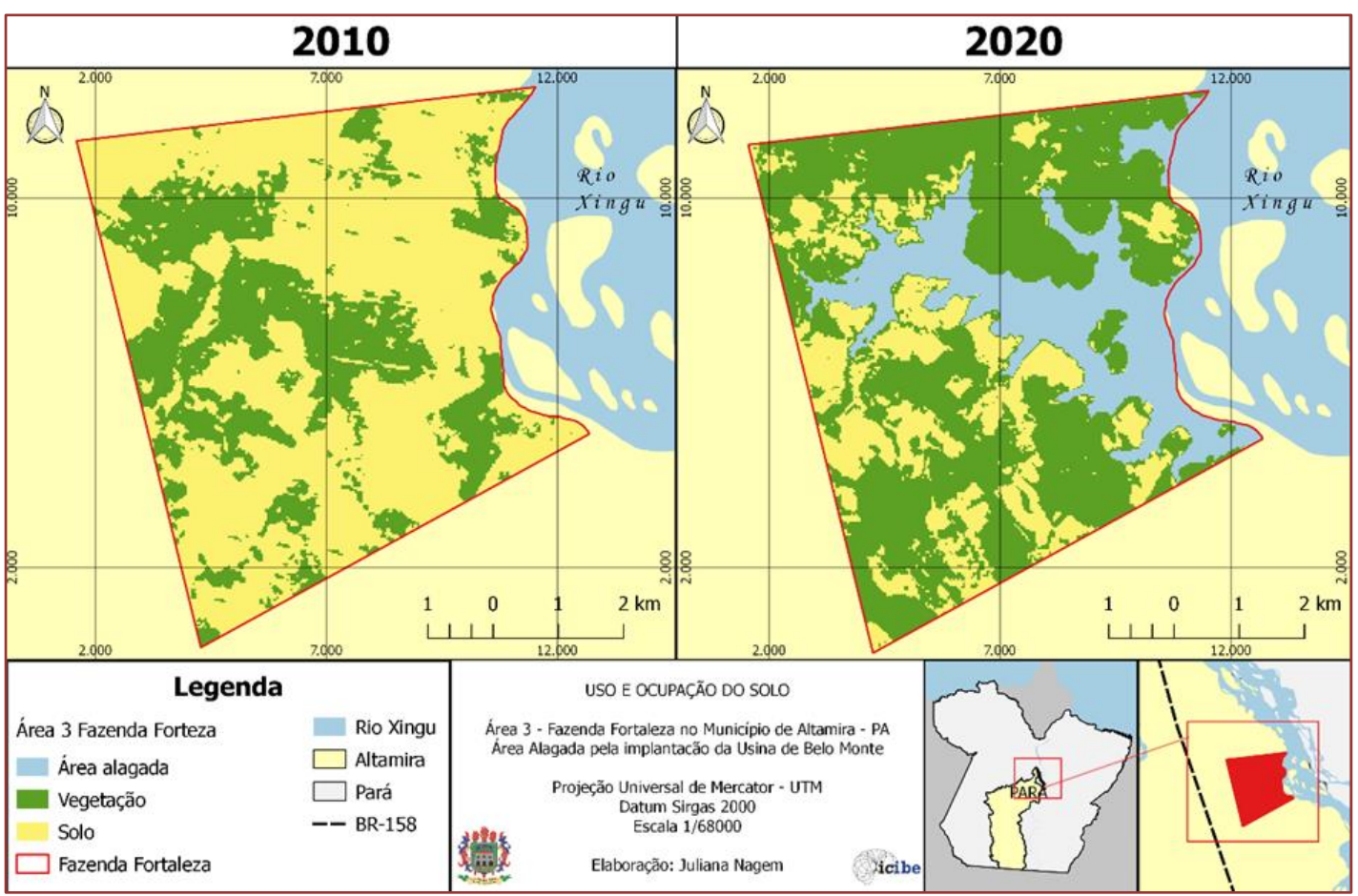

Fonte: Elaborado pela autora.

Dessa maneira, observa-se que $8,41 \mathrm{~km}^{2}$ ou 841,21296 hectares da área 3 foram inundados, correspondendo a $20,55 \%$ de seu território. Considerando o valor de $\mathrm{R} \$ 12,500$ por hectare, estima-se a indenização no valor de $\mathrm{R} \$ 10.512 .500,00$.

\section{CONSIDERACÕES FINAIS}

Este trabalho chegou ao seu objetivo realizar a classificação multitemporal do uso e cobertura no intervalo de 10 anos das 2 áreas, tendo como classes as áreas de solo, cobertura vegetal, hidrografia e outros, utilizando a plataforma online Google Earth Engine - GEE.

O software online GEE mostrou-se uma ferramenta poderosa para a realização de análises espaciais, importantíssimas para o monitoramento ambiental, uma vez que permite o processamento automatizado, sem necessidade da importação externa de imagens e todo seu processo de ajustamento, como a realização de mosaicos, recorte, retificação e georreferenciamento. Além disso, seu editor de código possui uma linguagem simplificada e com rápida execução.

Dessa forma, constata-se que o GEE é um importante aliado para as áreas de informação geográfica, classificação e monitoramento de regiões de interesse, podendo ser utilizados para analisar o comportamento populacional, o desmatamento e planejar o desenvolvimento das cidades. Portanto, sendo muito oportuna sua utilização para tais fins.

\section{REFERÊNCIAS}

[1] GANEM, Khalil Ali. Classificação da cobertura do solo na Caatinga a partir de imagens do Landsat8 e da ferramenta Google Earth Engine: uma comparação entre dados com e sem correção atmosférica. 2017. 202 f., il. Dissertação (Mestrado em Geociências Aplicadas). Universidade de Brasília, Brasília, 2017.

[2] GEE, Google Earth Engine, 2019. Disponível em < https://earthengine.google.com/>. Acesso em $07 / 12 / 2019$.

[3] IBGE, Instituto Brasileiro de Geografia e Estatística. Disponível em < https://www.ibge.gov.br/>. Acesso em 07/12/2019. 


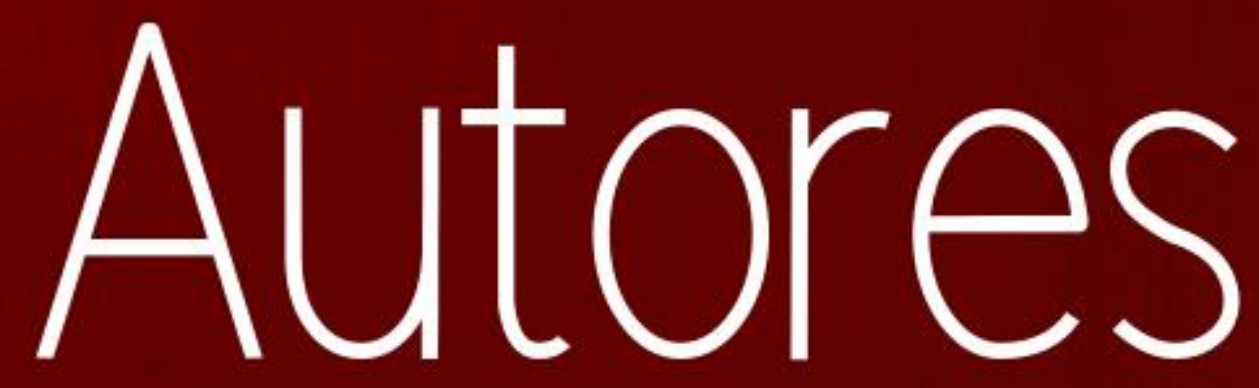




\section{JOSÉ HENRIQUE PORTO SILVEIRA (ORGANIZADOR)}

Bacharel e licenciado em Psicologia pela UFMG, Especialização em Percepção e Planejamento Urbano. Mestre em Gestão e Auditoria Ambiental, especialização em educação ambiental.

Consultor em percepção e educação ambiental. Sócio diretor da Alternativa Educação e Manejo Ambiental.

\section{ADRIANA MARIA GRIEBELER}

Engenheira Florestal pela Universidade Federal de Santa Maria (2017), licenciada pelo Programa de Formação de Professores para a Educação Profissional e Tecnológica (2018). Especialista em Estatística Aplicada (2019) e mestre em Engenharia Florestal pelo Programa de Pós-graduação em Engenharia Florestal UFSM (2019). Atualmente é doutoranda do Programa de Pós-graduação em Engenharia Florestal UFSM, onde desenvolve pesquisas na área de Silvicultura, com ênfase no desenvolvimento de estratégias para a otimização da produção de mudas clonais de Eucalyptus spp. Possui experiência na área de silvicultura, tecnologia de sementes e produção de mudas de espécies florestais nativas do Sul do Brasil, recuperação e enriquecimento de áreas alteradas, formação de povoamentos e educação ambiental.

\section{ALCIDO ALBERTO JOÃO}

Licenciado em Ensino de Física com habilitações em Energias Renováveis pela Universidade Rovuma - Nampula (2021). Tem experiência na área de Energias Renováveis, atuando sobretudo em temas sobre geração de energia hídrica e eólica em pequena escala

\section{ALINE ASSIS CARDOSO}

Engenheira Agrônoma, Mestre e Doutora em Agronomia (Solo e Água) pela UFG. Atualmente é integrante do grupo de pesquisa em solos da UFG (NucliSolos).

\section{AMANDA LOMBARDO FRUEHAUF}

Bacharel em Agroecologia na UFSCar, Centro de Ciências Agrárias Mestre em Ciências no Programa de Pós Graduação de Recursos Florestais da ESALQ, USP Cursa doutorado no Programa de Pós Graduação de Recursos Florestais da ESALQ, USP, com ênfase em geoprocessamento, uso da terra, ilha de calor, espaços livres , infraestrutura verde, arborização urbana, sustentabilidade.

\section{AMANDA REZZIERI MARCHEZINI}

Graduanda em Biotecnologia pela Universidade Federal de São Carlos. Foi bolsista de Iniciação Científica com o apoio da CNPQ na área de Economia Aplicada e bolsista de extensão pelo projeto Cálculo da Cesta Básica no Município de Araras. Atualmente, é bolsista de Iniciação Científica com apoio da CNPq no Instituto Agronômico de Campinas - Centro de Café Alcides de Carvalho

\section{ANA CAROLINE VITOR AVELAR}

Graduanda em Ciências Biológicas pelo Instituto Federal de Educação, Ciência e Tecnologia do Sul de Minas - Campus Muzambinho. Foi voluntária no Centro de Estudos Ambientais do IFSULDEMINAS (2018). Já atuou como bolsista no Laboratório Interdisciplinar do IFSULDEMINAS $(2018 / 2020)$.

\section{ANDRÉ AZEVEDO ROCHA}

Técnico do Instituto Regional da Pequena Agropecuária Apropriada - IRPAA 


\section{ANTÓNIO GONÇALVES FORTES}

Possui Bacharelato (2007) e Licenciatura (2009) em Ensino de Física pela Universidade Pedagógica de Moçambique, Mestrado em Engenharia Geológica pela Universidade de Aveiro - Portugal (2016), Especialização em Energias Renováveis pelo Instituto InterClasse - Brasil (2018) e Doutorando em Geociências: Geologia e Recursos Minerais pela UNICAMP - Brasil, desde 2017. Atualmente é professor na Universidade Rovuma - Nampula. É pesquisador na área de Física e Meio Ambiente e Energias Renováveis, atuando principalmente nos temas de sustentabilidade socioambiental e geração de energia solar, hídrica e eólica em micro e pequena escala. Tem experiência nas áreas de Gestão Ambiental, Geofísica, Geologia Sedimentar e Metamórfica.

\section{ANTONIO MARCOS DOS SANTOS}

Graduação em Geografia (Licenciatura) pela Universidade do Estado da Bahia (UNEB campus V). Mestrado e doutorado em Geografia pela Universidade Federal de Pernambuco (UFPE). Professor Adjunto do curso de Geografia lotado na Universidade de Pernambuco (UPE) campus Petrolina. Docente do Programa de Pós-Graduação em Ciências Ambientais (Ciências e Tecnologias Ambientais para o Semiárido) - nível mestrado (UPE) e do Programa de Pós-Graduação em Formação de Professores e Práticas Interdisciplinares - nível mestrado (UPE). Integra a Rede Internacional de Estudos sobre Solos Afetados por Sais da Food and Agriculture Organization of the United Nations (FAO).

\section{ANTÔNIO SÉRGIO DA COSTA}

Licenciado em Geografia e Ciências Sociais Mestre em Educação Professor EBTT - IFSULDEMINAS, Campus Avançado Três Corações

\section{ARI MELO MARIANO}

Professor Adjunto, Subchefe do Departamento de Engenharia de Produção (EPR) da Universidade de Brasília Doutorado em Administração (UFBA) / Negócios Internacionais(US), Universidad de Sevilla, 2010 Mestrado em Gestão da Globalização, Universidad de Sevilla, 2007 Especialização em Consumo Europeu, Universidad de Sevilla, 2006 Graduação em Marketing, Centro Universitário da Bahia, 2003

\section{CAMILA RODRIGUES LIMA}

Bacharel em Administração - 2014 a 2018 pelo Centro Universitário de Brasília - UniCEUB. Currículo: Camila já atuou como recepcionista,servidora do GDF e estagiária de RH do STF, tendo vida pública de 2013 a 2017.Nesse período, ingressou com êxito para o curso de Bacharelado em Administraçãopelo Centro Universitário de Brasília - UniCEUB, formando-se em 2018 comestudos na área de sustentabilidade e RSC. Após formação, atuou como Gerente deLoja do Grupo Lojas Americanas S.A. e hoje, é empreendedora do ramo de varejo ecompras.ca

\section{CAMILO RAFAEL PEREIRA BRANDÃO}

Graduado em Licenciatura em Ciências Biológicas pela Universidade do Estado da Bahia (UNEB). Realizou pesquisas na área de Resíduos Sólidos Urbanos (RSU) na graduação e foi bolsista ID no Programa Institucional de Bolsas de Iniciação à Docência (PIBID). Mestre em Desenvolvimento e Meio Ambiente Sergipe (PRODEMA - UFS) e Doutorando no Programa de Pós-graduação em Desenvolvimento e Meio Ambiente da Universidade Federal de Sergipe (PRODEMA - UFS). Membro do Grupo de Pesquisa Formação, Interdisciplinaridade e Meio Ambiente (GPFIMA / CNPq). Atualmente desenvolve pesquisas na área de gerenciamento de recursos hídricos com foco na Pegada Hídrica. Tem interesse em áreas correlacionadas a educação e meio ambiente.

\section{CARLOS LAÉCIO EVANGELISTA FRANCA}

Bolsista do PET Saneamento Ambiental da UNIVASF 


\section{CAROLINE HELENA RAMOS DE QUEIROZ}

Bacharel em Relações Internacionais - 2002 a 2006 pela Universidade Nacional de Yokohama, Japão; Mestre em Relações Internacionais - 2007 a 2008 pela Universidade Nacional de Yokohama, Japão; Bacharel em Administração - 20014 a 2019 pelo Cantro Universitário de Brasília (UniCEUB); Licenciada Plena em Pedagogia - 2017 a 2020 pela Faculdade de Filosofia, Ciências e Letras de Boa Esperança (FAFIBE). Atualmente empreendedora e administradora no ramo de construção civiel e locação de imóveis, com interesse constante e crescente no aperfeiçoamento profissional e pesquisas acadêmicas.

\section{CLÁUDIA REBECHI YOKOTA}

Engenharia Civil formada pela Universidade Estadual de Maringá. Especialista em Engenharia de Produção e Engenharia de Segurança do Trabalho. Mestrando no Programa de Pós-graduação em Sustentabilidade.

\section{CLAUDINO PITA RICHARD}

Licenciado em Ensino de Física com habilitações em Energias Renováveis pela Universidade Rovuma - Nampula (2021). Curso Técnico-Profissional em Informática no Centro Tecnológico Informático de Sussundenga (2011). Atualmente Presidente da Associação de Pesquisadores e Amigos do Meio Ambiente (APAMA). É pesquisador nas áreas de Energias Renováveis, atuando principalmente os temas: Energia hídrica em pequena escala e sustentabilidade ambiental de sistemas hidrelétricos. Tem experiências em Gestão de Empresas e Projetos.

\section{CLÉRISON DOS SANTOS BELEM}

Técnico do Instituto Regional da Pequena Agropecuária Apropriada - IRPAA

\section{CRISTINA MARTINELLI}

Mestranda em Sustentabilidade pelo IFPR/UEM. Possui graduação em Química Industrial pela Universidade Estadual de Maringá. Atualmente é professora do programa de empreendedorismo pela Secretária de Educação do Estado do Paraná.

\section{DANIELA FERREIRA CARDOSO}

Licenciada em Ciências Biológicas - UNIFEG; Mestre em Tecnologia Ambiental - UNIAERP; Doutoranda em Educação - UNICAMP; Orientadora do Programa Residência Pedagógica - CAPES; Orientadora na esmpresa SOMA JR.

\section{DAYANA MACHADO ROCHA}

Graduação em Ciências Econômicas pela Universidade Federal de Roraima (2016), mestre em Agroecologia pela Universidade Estadual de Roraima

\section{EMERSON CLAYTON ARANTES}

Graduação em Administração pela Universidade Estadual de Londrina (2003), especialização em Políticas Públicas e Desenvolvimento Sustentável pela Universidade Federal de Roraima (2006), mestrado em Economia pela Universidade Federal do Rio Grande do Sul (2009), Doutorado em Educação pela Universidade Federal de Juiz de Fora (2019), Multiplicador de Conhecimentos em Micro e Pequenas Empresas (MPEs) pela FIA Business School e Conselho Federal de Administração (2019). Atualmente é professor efetivo da Universidade Federal de Roraima. 


\section{EMMELY OLIVEIRA DA TRINDADE}

Doutoranda em Química Orgânica pela Universidade Federal da Paraíba, Mestra em Química Orgânica (2017) pela mesma instituição. Possui graduação em Química Industrial (2014) e Licenciatura Plena em Química (2017) pela Universidade Federal da Paraíba. Tem experiência na área de Química Orgânica, com ênfase em Síntese Orgânica, atuando principalmente na síntese de moléculas bioativas derivadas de produtos naturais. Possui experiência na área de Engenharia Química com ênfase em carvão ativado, tratamento de água e tratamento de efluentes.

\section{ERNESTO TAPERERO FERNANDO}

Licenciado em Ensino de Física com habilitações em Energias Renováveis pela Universidade Rovuma - Nampula (2020). Tem experiência na área de Energias Renováveis, sobretudo as energias hídrica, solar e eólica em pequena escala. Atualmente é Apresentador e Jornalista na TV Vitória em Nampula.

\section{EVA DE MELO FERREIRA}

Doutora em Saneamento, Meio Ambiente e Recursos Hídricos pela Universidade Federal de Minas Gerais, atua nas áreas de Ciência do Solo e Meio Ambiente. É autora de trabalhos publicados em periódicos científicos e em congressos internacionais.

\section{EVERLENE DE SOUSA FREITAS}

Graduada em Engenharia Ambiental e Sanitária pela UniFanor Wyden. Já atuou como Monitora Voluntária na Rede Municipal de Educação Básica no Município de Fortaleza. Prestou serviços para a Companhia de Água e Esgoto do Ceará. Foi Estagiária de Nível Superior na Autarquia Municipal de Meio Ambiente do Município de Pacatuba. Atualmente trabalha com consultoria de Licenciamento Ambiental no Estado Ceará

\section{FABÍOLA MANGABEIRA CEOLATO DA SILVA}

Graduanda em Licenciatura em Ciências Biológicas no Instituto Federal de Educação, Ciência e Tecnologia do Sul de Minas Gerais - Campus Muzambinho, tendo atuado como estagiária na Secretária Municipal de Guaxupé, Mg (2019) e com experiência na área de Licenciatura, participado em eventos como: Encontro da Biologia no If Sul de Minas, feira Científica, Palestras de Licenciatura (2018, 2019, 2020). Atualmente realizando Projeto na área da Educação titulado "Análise do Processo de Ensino - Aprendizagem dos anos finais do Ensino Fundamental e Ensino Médio em tempos de Pandemia".

\section{FABRICIO CURVELO CAMARA SALES}

Graduado em Direito pelo Centro Universitário de Brasília - UniCEUB, Pós-Graduando em Direito Constitucional pela Faculdade Anhanguera/LFG. Já atuou como secretário administrativo na Secretaria de Segurança Público do Distrito Federal - SSP/DF e como assistente administrativo na Fundação Universidade de Brasília - FUB. Atualmente, atua como assessor de apoio técnico da Secretaria do Gabinete da PGJ no Ministério Público do Distrito Federal e Territórios - MPU/MPDFT. Interessa-se pela análise do Direito Constitucional e suas ramificações.

\section{FELIPE TURCHETTO}

Possui graduação em Engenharia Florestal pela Universidade Federal de Santa Maria Campus Frederico Westphalen (2011), mestrado (2015) e doutorado (2018) em Engenharia Florestal pela Universidade Federal de Santa Maria. Atualmente é professor adjunto no Departamento de Engenharia Florestal, na Universidade Federal de Santa Maria Campus Frederico Westphalen. Tem experiência na área de Recursos Florestais, com ênfase em Manejo de Florestas Nativas, Silvicultura e Estatística Experimental. 


\section{FRANCISCO EDIRLAN DE SOUSA FREITAS}

Mestrando do Programa de Pós-Graduação em Energia e Ambiente pela Universidade da Integração Internacional da Lusofonia Afro-Brasileira - UNILAB. Graduado em Química pela Universidade Federal do Ceará - UFC. Especialista em Engenharia Ambiental - Instituto Executivo e em Elaboração de Projetos para a Gestão Municipal de Recursos Hídricos pelo Instituto Federal de Educação, Ciência e Tecnologia do Ceará - IFCE. Já atuou como docente na Rede Estadual de Educação Básica no Estado do Ceará, foi bolsista do Laboratório Núcleo de Águas, vinculado ao Departamento de Química Analítica e Físico-Química da UFC. Atualmente, trabalha na Companhia de Água e Esgoto do Ceará - Cagece, com soluções em saneamento ambiental, tendo como foco o controle operacional, combate as perdas na distribuição de água, instrumentação de equipamentos medidores de pressão e vazão em Sistemas de Abastecimento de Água.

\section{GUILHERME DAVI MUMBACH}

Formado em Engenharia Ambiental e Sanitária pela Universidade Federal da Fronteira Sul (2015), possui mestrado em Engenharia Química pela Universidade Federal de Santa Catarina (2017), onde cursa o Doutorado na mesma área. Possui os seguintes scores: Scopus - Fator H: 4; Publons - Fator $\mathrm{H}: 4$. Desenvolve, atualmente, pesquisas com foco em tecnologias limpas para reciclagem de resíduos plásticos e conversão termoquímica de rejeitos agroindustriais.

\section{INAJÁ FRANCISCO DE SOUSA}

Possui graduação em Meteorologia pela Universidade Federal da Paraíba (1987), mestrado em Meteorologia Aplicada pela Universidade Federal da Paraíba (1991), doutorado em Recursos Naturais pela Universidade Federal de Campina Grande (2005) e Pós-doutorado em modelagem hidrológica realizado no Instituto de Agricultura Sostenible - IAS/CISC desenvolvido em CórdobaEspanha (2014). Atualmente é professor associado da Universidade Federal de Sergipe, lotado no Departamento de Engenharia Agronômica. Atuou como Coordenador do Programa de Pós Graduação em Recursos Hídricos - PRORH durante os anos de 2017 a 2020. Também atuou como Coordenador Adjunto no Programa de Pós Graduação em Desenvolvimento e Meio Ambiente no ano de 2016. Atua como professor permanente nos Programas de Pós Graduação - PRODEMA e PRORH. Tem experiência na área de Agronomia, com ênfase em Agrometeorologia, atuando principalmente nos seguintes temas: modelagem hidrológica em bacia hidrográfica, necessidades hídricas de culturas e modelagem de agricultura irrigada.

\section{IONE CRISTINA DANTAS RIBEIRO}

Possui graduação em Serviço Social pela Universidade Federal do Piauí (2003). Mestrado em Sociologia pela Universidade Federal do Piauí (2016) na linha de pesquisa territorialidades, sustentabilidades, ruralidades e urbanidades. Atuou como professora no curso de Serviço Social em instituições como Faculdade Raimundo Sá, Universidade de Santo Amaro (Polo Teresina) e Universidade Luterana do Brasil (Polo Teresina) e Faculdade UNIRB - Piauí. Possui experiência como professora de Pós-graduação na Universidade Estadual do Vale do Acaraú. Atuou como assistente social do município de Nazária (PI); gerente de planejamento na Coordenadoria da Juventude do estado do Piauí e Coordenadoria Estadual de Segurança Alimentar e Erradicação da Fome do Piauí. Atualmente é professora da Faculdade Uninassau Redenção em Teresina-Piauí e na Faculdade de Tecnologia e Educação Superior Profissional-Fatesp.

\section{JANAINA FRACARO DE SOUZA GONÇALVES}

Possui graduação em Engenharia Mecânica pela Universidade Estadual de Maringá - UEM (2005), mestrado em Engenharia Mecânica Aeronáutica pelo Instituto Tecnológico de Aeronáutica - ITA (2007), doutorado pelo ITA em Engenharia Mecânica Aeronáutica (2013) e Pós-doutorado em Engenharia Mecânica pela UNESP-Bauru (2016). Desde novembro de 2012 atua como professor da Divisão de Engenharia Mecânica na Universidade Tecnológica Federal do Paraná - UTFPR - Campus Londrina. É também Coordenadora do Grupo BAJA (UTFPR ? Campus Londrina). Participa como pesquisador voluntário de pesquisas na pós-graduação e na graduação pelo laboratório Centro de 
Competência em Manufatura do ITA (CCM/ITA). Tem experiência industrial e acadêmica na área de Engenharia Mecânica e Produção, atuando principalmente nos seguintes temas: análise de desempenho de processos de fabricação, processos de manufatura sustentável, tratamento de efluentes industrias e desenvolvimento de produtos sustentáveis (aplicação de óleos vegetais como lubrificantes industriais).

\section{JANKSYN BERTOZZI}

Possui Bacharelado em Química Tecnológica pela Universidade Estadual de Londrina (2006) e mestrado em Química pela Universidade Estadual de Maringá (2008) e doutorado em Ciências na área de concentração Química pela Universidade Estadual de Maringá (2013). Atualmente é professor Adjunto da Universidade Tecnológica Federal do Paraná.

\section{JEAN CONSTANTINO GOMES DA SILVA}

Possui graduação em Engenharia Química pela Universidade Federal da Paraíba (2014), mestrado em Energias Renovaveis pela Universidade Federal da Paraiba (2017). Tem experiência na área de aproveitamento e valorização de residuos sólidos e tratamento de efluentes industriais para fins de reuso. Possui os seguintes scores: Scopus - Fator H:11; Publons - Fator H:9 (em 19/03/2021). Atualmente é bolsista de Doutorado pelo programa de Engenharia Química da UFSC.

\section{JOÃO LUCAS QUEIROZ BRANDÃO}

Graduando do curso de Serviço Social pela UNINASSAU - Redenção (2017 - 2020).

\section{JOÃO LUIS RODRIGUES}

Graduado em Geografia pela Universidade Vale do Rio Verde Três Corações.

\section{JOSÉ LUIZ FRANCISCO ALVES}

Possui graduação em Engenharia Química pela Universidade Federal da Paraíba (2014), mestrado em Engenharia Química pela Universidade Federal de Santa Catarina (2016) e doutorado em Engenharia Química pela Universidade Federal de Santa Catarina (2021). Tem experiência na área de tratamento de efluentes industriais para fins de reuso. Possui os seguintes scores: Scopus - Fator H:10; Publons - Fator H:9 (em 19/03/2021). Atualmente é bolsista de Pós-doutorado Júnior do CNPq.

\section{JOYCE APARECIDA PÍFANO DE OLIVEIRA}

Técnica em Meio Ambiente, Engenheira Ambiental e de Segurança do Trabalho e Especialista em Gestão e Educação Ambiental. Atualmente, atua como professora no Curso Técnico em Segurança do Trabalho no Colégio Barbosa Ferraz e como Consultora Ambiental e de Segurança do Trabalho.

\section{JULIANA TAMIRES FERREIRA KIZAHY NAGEM}

Acadêmica do curso Bacharelado em Engenharia Cartográfica e de Agrimensura pela Universidade Federal Rural da Amazônia, início em 2016 e formação prevista para 2021. Possui experiência em Geoprocessamento, Regularização Fundiária, Topografia e Geodésia, entre outros. Atuou como bolsista no Laboratório de Integração de Informações Agrárias, Econômicas e Ambientais para Análise Dinâmica da Amazônia - INTEGRADATA, no âmbito do projeto Gestão dos Conflitos Territoriais Rurais no Municípios de Santarém e Castanhal no Estado do Pará, atuando como de auxiliar de geoprocessamento e alimentando o Sistema de Informações Fundiárias. 


\section{KAREN PATRÍCIA MACEDO CESÁRIO}

Graduanda do $10^{\circ}$ semestre do curso de Engenharia Cartográfica e de Agrimensura da Universidade Federal Rural da Amazônia (UFRA), experiência profissional no ano de 2019 na Companhia de Saneamento do Estado do Pará atuando na área de SIG na construção da base de dados cartográficas, também em 2019 como Bolsista no Laboratório de Integração de Informações Agrárias, Econômicas e Ambientais para Análise Dinâmica da Amazônia (IntegraData Amazônia), sistematizando os processos de regularização fundiária do INCRA para o acervo de dados em SIG. Em 2020 e 2021 Voluntária Civil, na Defesa Civil do Estado do Pará juntamente ao Corpo de Bombeiros Militar do Pará, atuando amplamente na área da cartografia. Com boa oratória e facilidade para trabalhar em equipe. Tenho interesse e facilidade na áreas de legislações ambientais e agrárias.

\section{KÁTIA VALÉRIA MARQUES CARDOSO PRATES}

Possui graduação em Biologia pela Universidade Federal de São Carlos (1993), mestrado em Hidraúlica e Saneamento (1997) e doutorado em Ciências da Engenharia Ambiental (2003) ambos pela Universidade de São Paulo - USP - Escola de Engenharia de São Carlos - EESC. Atualmente é professora da Universidade Tecnológica Federal do Paraná - Campus Londrina no Curso de Engenharia Ambiental. Docente permanente do Programa de Pós-graduação (mestrado acadêmico) em Engenharia Ambiental, Campus Londrina. Tem experiência na área de Microbiologia Aplicada a Engenharia Sanitária, atuando principalmente nos seguintes temas: tratamento de águas residuárias, remoção de nutrientes, recursos hídricos e resíduos sólidos.

\section{LAIS REGINA GOMES DE OLIVEIRA FREITAS}

Especialista em Educação Ambiental pela Universidade Federal do Ceará - UFC, licenciada em Geografia pela Universidade Estadual - UECE, centro de ciências e tecnologia. Já atuou como docente na Rede Estadual de Educação Básica no Estado do Ceará e Municipal na Cidade de São Benedito na Região da Serra da Ibiapaba.

\section{LEILYANE CONCEIÇÃO DE SOUZA COELHO}

Graduação em Farmácia pela Universidade Federal de Pernambuco/UFPE (2002), mestrado em Ciências Farmacêuticas pela UFPE (2005) e doutorado em Biologia Celular e Estrutural pela Universidade Estadual de Campinas/UNICAMP (2014). Professora Adjunto da Universidade de Pernambuco - UPE, Campus Petrolina, área Embriologia/Histologia Humana desde 2007. Exerci a função de vice-diretoria do campus durante o quadriênio 2008-2012. De fevereiro/2015 a setembro/2016, exerci a função de Assessoria da Direção do campus. Mais uma vez, assumi a vicedireção do campus em dezembro/2016 até outubro/2020. Fui designada diretora do campus, em novembro/2020, para conclusão do mandato, com prorrogação até 19 de abril de 2021.

\section{LUCAS DANIEL NORONHA FERREIRA}

Graduando do 8o semestre do curso de Bacharelado em Engenharia Cartográfica e de Agrimensura pela Universidade Federal Rural da Amazônia. Atualmente atua como Instrutor Monitor na Escola de Governança Pública do Estado do Pará (EGPA) / Governo do Estado do Pará, é Assessor Administrativo e de Gestão do Projeto TEA (UFRA) com vínculo à Fundação de Apoio à Pesquisa (FUNAPE) e Bolsista PIBEX pelo Projeto de Extensão Clube de Cartografia visando elaborar produtos cartográficos para o público TEA.

\section{LUCIANA LEAL PIMENTEL OLIVEIRA}

Mestre em Engenharia Civil (2014). Engenheira Sanitarista e Ambiental pela UFPA (2012). Atualmente é docente do Instituto Federal de Educação, Ciência e Tecnologia do Pará. Pesquisadora do Grupo de Pesquisa em Água, Energia e Sustentabilidade da Amazônia (GAES-UFPA) e Núcleo de Modelagem Aplicada à Engenharia (NUMAE-UNIFAP). Possui experiência na área de Engenharia Sanitária e Ambiental, com ênfase em Recursos Hídricos e Saneamento Ambiental, atuando em Gestão de Recursos Hídricos, Riscos e Acidentes Ambientais, Saneamento e Saúde Pública. 


\section{LUIZ FERNANDO FERREIRA}

Graduando em Ciências Biológicas pelo Instituto Federal de Educação, Ciência e Tecnologia do Sul de Minas - Campus Muzambinho.

\section{MAGDA ADELAIDE LOMBARDO}

Professora Titular da Universidade Estadual Paulista "Júlio de Mesquita Filho (UNESP), Professora Señor no programa de Recursos Florestais da Escola Superior de Agricultura "Luiz de Queiroz" (ESALQ), Universidade de São Paulo (USP). Investigador colaborador no Instituto de Estudos Avançados (IEA), Universidade de São Paulo (USP).

\section{MARIA LUÍZA DE CASTRO GARCIA}

Maria Luiza de Castro Garcia é estudante do curso de Engenharia Cartográfica e de Agrimensura na Universidade Federal Rural da Amazônia desde 2016. Realizou estágio no ano de 2017 na Secretaria Municipal de Meio Ambiente, onde atuou no Departamento de Projeto e Paisagismo - DPP, trabalhando na área orçamentária, com ênfase em obras de pequeno e médio porte. Em 2019 atuou como estágiária na Diretoria de Geotecnologias ? DIGEO, da Secretaria Estadual de Meio Ambiente, onde trabalhava na elaboração e implementação de ferramentas de Geoprocessamento e Sensoriamento Remoto, fornecendo e atuando no suporte ao ordenamento e o zoneamento ambiental do Estado.

\section{MICHEL DE PAULA ANDRAUS}

Engenheiro Agrônomo, Mestre e Doutor em Agronomia (Solo e Água) pela UFG. Atualmente é docente titular na área de solos da Uniaraguaia e UNIP.

\section{MIRIAM CLEIDE CAVALCANTE AMORIM}

Professora do Colegiado de Engenharia Agrícola e Ambiental e Tutora do PET Saneamento Ambiental da UNIVASF

\section{MOMADE JAIME CHAU}

Mestrando em Educação/Ensino de Ciências Naturais na UniRovuma. Possui Licenciatura em Ensino de Física, pela Universidade Pedagógica de Moçambique (2011). Possui conhecimentos sólidos e desenvolve pesquisas na área de energias renováveis, sobre tudo na montagem de pequenos sistemas de geração de energia com base nas fontes renováveis. Já trabalhou como docente convidado da Academia Militar Marechal Samora Machel. Actualmente é Docente, Diretor do curso de Física e coordenador dos laboratórios de Mecânica e Eletromagnetismo na Universidade Rovuma

\section{MONIQUE DIAS BENEDETTI}

Bióloga (Modalidade Licenciatura) - Instituto Federal de Educação, Ciência e Tecnologia - Campus Muzambinho; Técnica em Química pela ETEC Prof. Rodolpho José del Guerra - São José do Rio Pardo; Mestranda em Ciências Biológicas na área de concentração Interação Patógeno - Hospedeiro com ênfase em Parasitologia pela Universidade Federal de Alfenas (UNIFAL-MG). Pós-Graduanda (lato sensu) em Análises Clínicas e Microbiologia pela Faculdade Venda Nova do Imigrante (FAVENI).

\section{MOZART DOS SANTOS SILVA}

Técnico em Agrimensura pela Escola Técnica Federal do Pará, Licenciado em Matemática pela Universidade do Estado do Pará, Bacharel em Ciência da Computação pela Universidade Federal do Pará e Graduando em Engenharia Cartográfica e de Agrimensura pela Universidade Federal Rural da Amazônia. 


\section{ODILON AUGUSTO RÊGO DE LIMA}

Possui graduação em Gestão Ambiental pelo Instituto Federal de Educação, Ciência e Tecnologia do Pará(2019) e ensino-médio-segundo-grau pelo Centro Educacional Manilhense (2013). Atualmente é graduando em Licenciatura Plena em Geografia do Instituto Federal de Educação, Ciência e Tecnologia do Pará.

\section{OTÁVIO AKIRA SAKAI}

Concluiu o doutorado em Física pela Universidade Estadual de Maringá, em 2008. Atualmente é Professor EBTT do Instituto Federal do Paraná - Campus Umuarama e participa como pesquisador no Mestrado em Sustentabilidade UEM/IFPR. Atua na área de Física, com ênfase em Propriedades Óticas e Espectroscopia da Matéria Condensada; Outras Interação da Matéria com Radiação e Partículas. Desenvolve projetos de pesquisa na área de tecnologia de produtos naturais com ênfase em desenvolvimento de produtos (aplicações na indústria, farmácia, agronomia etc), otimização de processos de extração e caracterização por meio da Espectroscopia UV/Vis e Infravermelho, Cromatografia Líquida de alta eficiência, Voltametria e Propriedades físico-química.

\section{PATRICK RAFAEL SILVA CORRÊA}

Graduando do curso de Engenharia Cartográfica e de Agrimensura pela Universidade Federal Rural da Amazônia - UFRA, foi monitor das disciplinas Topografia, Cartografia, Sensoriamento Remoto e Geoprocessamento. Participou do estágio na Secretária de Transporte (SETRAN) no departamento de Planejamento - DIRPLAN com Geoprocessamento e atualmente realiza o estágio na empresa privada Innovare Consultoria Ambiental realizando o planejamento e viabilidade de projetos utilizando o Geoprocessamento.

\section{PAULO BAPTISTA ALFACE}

Licenciado em Ensino de Física com habilitações em Energias Renováveis pela Universidade Rovuma - Nampula (2021). Técnico-Profissional em Eletricidade no Instituto Industrial e Comercial Joaquim Marra - Chimoio (2014). Tem experiência na área de Eletricidade e Energias Renováveis, atuando sobretudo em temas sobre geração, instalação e distribuição de energia hídrica e eólica em pequena escala

\section{PAULO CÉZAR GONÇALVES}

Possui graduação em Manutenção Industrial pela Universidade Tecnológica Federal do Paraná (2015) e mestrado em Mestrado em Engenharia Ambiental pela Universidade Tecnológica Federal do Paraná (2019). Tem experiência na área de Engenharia de Materiais e Metalúrgica, com ênfase em Usinagem, atuando principalmente nos seguintes temas: metalworking fluid, moringaceae oil, machining process, tribology e vegetable-based oil.

\section{PAULO RENATO MESQUITA PELLEGRINO}

Professor Associado do Departamento de Design da Faculdade de Arquitectura e Urbanismo da Universidade de São Paulo (FAU-USP), Vice-Coordenador de LABVERDE.

\section{PAULO ROBERTO CUOCO DE MELO}

Bacharel em Administração e Pós Graduando em Gestão do Agronegocio com extensa experiência profissional em Gerência Administrativa e Operacional, atuando em propriedades rurais no DF e Entorno, com foco na engorda de bovinos e produção de grãos em larga escala.

\section{RAFAEL FERNANDES BARROS DE SOUZA}

Licenciado, mestre e doutor em filosofia pela Unicamp. 


\section{RAFAEL NATAL XAVIER SOUSA}

Graduado em Ciências Biológicas pelo Instituto Federal de Educação, Ciência e Tecnologia do Sul de Minas Gerais (IFSULDEMINAS) - Câmpus Inconfidentes (2016); Realizou intercâmbio na Faculdade de Ciências da Universidade do Porto (FCUP -UP) em Portugal/PT (2014-2015); Foi bolsista pela CAPES no Programa Institucional de Bolsas de Iniciação à Docência (PIBID). Atualmente atua como biólogo no controle de qualidade microbiológico da empresa CIMED - Indústria Farmacêutica.

\section{REGIANE APARECIDA NEGRI}

Licenciada em Ciências Biológicas e Especialista em Educação Infantil - Instituto Federal de Educação, Ciência e Tecnologia do Sul de Minas Gerais - Campus Inconfidentes

\section{RÊNNIO FELIX DE SENA}

Possui graduação em Engenharia de Alimentos pela UFPB (2002), mestrado (2005) e doutorado (2009) em Engenharia Química pela UFSC, com doutoramento sanduíche em Engenharia Química pela Rheinisch Westfälische Technische Hochschule (RWTH), Aachen, Alemanha (2007). Atualmente é Professor Associado I da UFPB. Tem experiência na área de Engenharia e Tecnologia Química, com ênfase em aproveitamento de resíduos e tratamentos de efluentes industriais, atuando principalmente nos seguintes temas: tratamento de efluentes, processos de oxidação avançada, flotação por ar dissolvido, produção e caracterização de carvão ativado, adsorção, biorreatores de membrana (MBR), combustão de biomassa e análise cromatográfica de poluentes industriais. Desde 2011, atua no Programa de Pós-graduação em Engenharia Civil e Ambiental (PPGECAm) da UFPB, na área de concentração Saneamento Ambiental.

\section{RICARDO FRANCISCO ALVES}

Possui graduação em Engenharia de Materiais pela Universidade Federal da Paraíba (2015) e mestrado em Engenharia Mecânica pela Universidade Federal da Paraíba (2018). Tem experiência na área de Engenharia de Materiais e Metalúrgica, com ênfase em Engenharia de Materiais e Metalúrgica, atuando principalmente nos seguintes temas: ligas de memórias de forma, metalurgia, processos de fabricação, tratamentos térmicos e fundição.

\section{RITA TASSIANA DA COSTA}

Licenciada em Ciências Biológicas - Instituto Federal de Educação, Ciência e Tecnologia do Sul de Minas Gerais - Campus Inconfidentes

\section{SIMONE APARECIDA RIGOBELI VANALLI}

Possui graduação em Letras (Habilitação Língua Portuguesa) pela Universidade Estadual de Maringá (2000) e em Pedagogia, também pela UEM (2010). É Professora do Ensino Fundamental do Município de Umuarama desde 2012. Tem experiência na área de Educação, com ênfase em Linguagem e Educação, atuando principalmente nos seguintes temas: Educação Infantil e Influência do Discurso na Aprendizagem.

\section{STELLA ALONSO ROCHA}

Atualmente é Docente/Pesquisadora do Programa de Pós-Graduação em Sustentabilidade - PSU e Professora do Instituto Federal do Paraná - Campus Umuarama. Atuação nas áreas de processos de Separação e Misturas e Modelagem Matemática, com ênfase em otimização de processos.

\section{WILSON MOZENA LEANDRO}

Doutor em Produção Vegetal, é docente na Escola de Agronomia da Universidade Federal de Goiás, atuando principalmente em Ciências do Solo. 


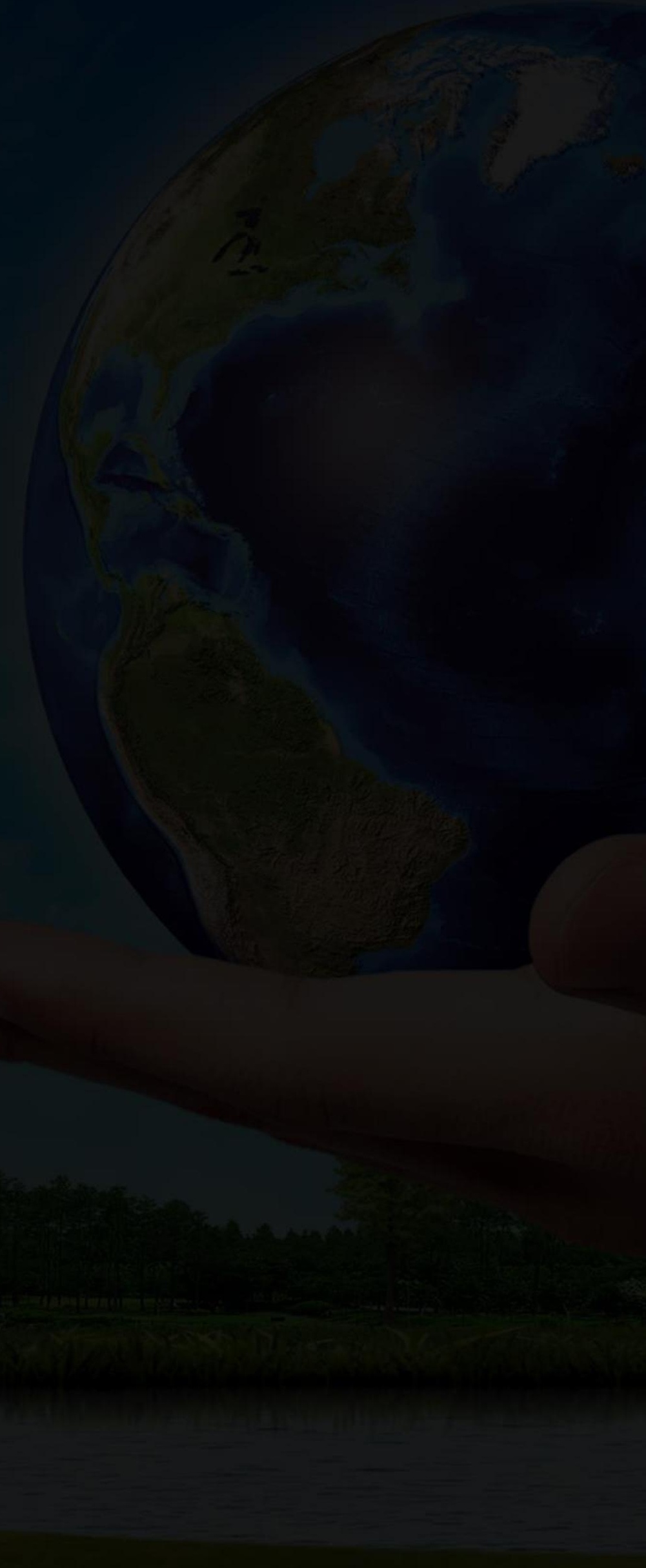

